\title{
Hydroacoustic Evaluation of Juvenile Salmonid Passage at The Dalles Dam in 2004
}

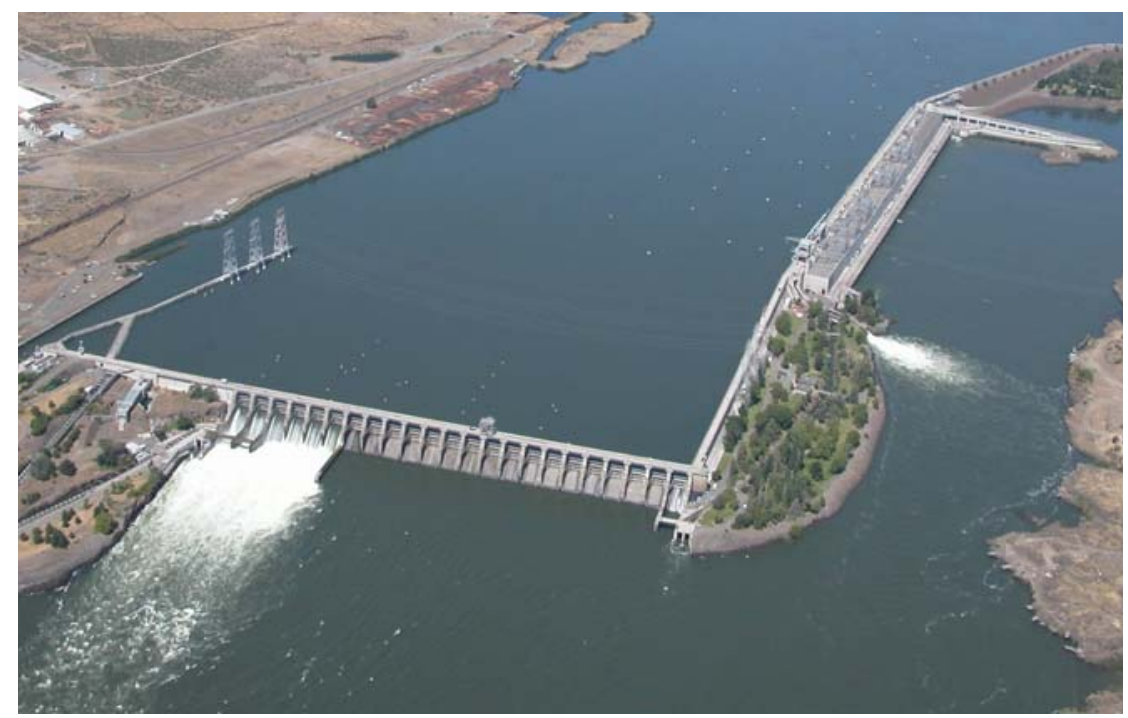

GE Johnson

ME Hanks

F Khan

CB Cook

JB Hedgepeth

RP Mueller
CL Rakowski

MC Richmond

SL Sargeant

JA Serkowski

JR Skalski

FINAL REPORT

June 2005

Prepared for the U.S. Army Corps of Engineers

Portland District, Portland, Oregon

Under a Work for Others Agreement

with the U.S. Department of Energy

Contract DE-AC05-76RL01830

Pacific Northwest

National Laboratory

Operated by Battelle for the

U.S. Department of Energy 


\title{
DISCLAIMER
}

This report was prepared as an account of work sponsored by an agency of the United States Government. Neither the United States Government nor any agency thereof, nor Battelle Memorial Institute, nor any of their employees, makes any warranty, express or implied, or assumes any legal liability or responsibility for the accuracy, completeness, or usefulness of any information, apparatus, product, or process disclosed, or represents that its use would not infringe privately owned rights. Reference herein to any specific commercial product, process, or service by trade name, trademark, manufacturer, or otherwise does not necessarily constitute or imply its endorsement, recommendation, or favoring by the United States Government or any agency thereof, or Battelle Memorial Institute. The views and opinions of authors expressed herein do not necessarily state or reflect those of the United States Government or any agency thereof.

\author{
PACIFIC NORTHWEST NATIONAL LABORATORY \\ operated by \\ BATTELLE \\ for the \\ UNITED STATES DEPARTMENT OF ENERGY \\ under Contract DE-AC05-76RL01830
}

Printed in the United States of America

\author{
Available to DOE and DOE contractors from the \\ Office of Scientific and Technical Information, \\ P.O. Box 62, Oak Ridge, TN 37831-0062; \\ ph: (865) 576-8401 \\ fax: (865) 576-5728 \\ email: reports@adonis.osti.gov
}

\author{
Available to the public from the National Technical Information Service, \\ U.S. Department of Commerce, 5285 Port Royal Rd., Springfield, VA 22161 \\ ph: (800) 553-6847 \\ fax: (703) 605-6900 \\ email: orders@ntis.fedworld.gov \\ online ordering: http://www.ntis.gov/ordering.htm
}

This document was printed on recycled paper. 


\title{
Hydroacoustic Evaluation of Juvenile Salmonid Passage at The Dalles Dam in 2004
}

\author{
GE Johnson \\ ME Hanks ${ }^{1}$ \\ F Khan \\ CB Cook \\ JB Hedgepeth ${ }^{2}$ \\ RP Mueller \\ CL Rakowski \\ MC Richmond \\ SL Sargeant \\ JA Serkowski \\ JR Skalski ${ }^{3}$
}

FINAL REPORT

June 2005

Prepared for the U.S. Army Corps of Engineers

Portland District, Portland, Oregon

Under a Work for Others Agreement

with the U.S. Department of Energy

Contract DE-AC05-76RL01830

Pacific Northwest National Laboratory

P.O. Box 999

Richland, Washington 99352

\footnotetext{
${ }^{1}$ BAE Systems Inc., Stevenson, Washington

${ }^{2}$ Tenera Environmental, LLC, San Luis Obispo, California

${ }^{3}$ University of Washington, Seattle, Washington
} 



\section{Summary}

The U.S. Army Corps of Engineers Portland District engaged the Pacific Northwest National Laboratory to evaluate fish passage at The Dalles Dam in 2004. The goal of the study was to provide information on smolt passage at The Dalles Dam that will inform decisions on long-term measures and operations to enhance sluiceway and spill passage and reduce turbine passage in order to improve smolt survival at the dam. The study addressed two of the main programs dedicated to improving juvenile salmonid survival at The Dalles Dam: Spillway Improvements and Surface Flow Bypass.

The study objectives (see below) were met using a combination of hydroacoustic and hydraulic data. The study incorporated fixed-location hydroacoustic methods across the entire project, with especially intense sampling at the sluiceway and spillway using multiple split-beam transducers at selected locations. At the sluiceway nearfield, we used an acoustic camera to track fish. The fish data were interpreted and integrated with hydraulic data from a computational fluid dynamics (CFD) model and in-field acoustic Doppler current profiler (ADCP) measurements. Data were collected in the framework of an "experiment" to compare two sluiceway operations: West only (Sluice 1 [SL 1]) vs. West+East (SL 1 + SL 18). The 2004 study was divided into two periods: spring (April 19 to June 5) and summer (June 6 to July 17).

During the study, daily outflow at TDA ranged from 124 to $289 \mathrm{kcfs}$. Mean daily outflow was $209 \mathrm{kcfs}$ in spring and $189 \mathrm{kcfs}$ in summer. Outflow peaked in early June. During the 2004 study, total project outflow was $76 \%$ of the 10 -year average for spring and $77 \%$ of the 10 -year average for summer. Daily powerhouse discharge averaged $122 \mathrm{kcfs}$ in spring and $110 \mathrm{kcfs}$ in summer. Spill for fish protection commenced on April 12. Daily spill flow during our study ranged from 49 to 119 $\mathrm{kcfs}$, with a mean of $82 \mathrm{kcfs}$ ( $39 \%$ of total) in spring and $74 \mathrm{kcfs}(39 \%$ of total) in summer. Daily sluice flow ranged from about 3.0 to $4.6 \mathrm{kcfs}$, depending on experimental treatment and forebay elevation. In spring and summer, mean sluice discharge was $2.2 \%$ and $2.4 \%$ of total project discharge, respectively.

Our study encompassed the majority of the migration period for yearling (stream-type) Chinook (Oncorhyncus tshawytscha), coho (O. kisutch), and sockeye (O. nerka) salmon as well as steelhead (O. mykiss) trout and subyearling (ocean-type) Chinook salmon. Passage of yearling fish peaked in mid- to late May. Passage of subyearling Chinook salmon, the most abundant salmonid fish migrating downstream through The Dalles Dam, peaked at the end of June. During the spring study period, species composition was: yearling Chinook salmon (60\%); steelhead (16\%); sockeye (11\%); and coho $(9 \%)$. During the summer study period, subyearling Chinook salmon comprised $89 \%$ of the outmigration.

The findings, summarized by objective, were as follows:

Estimate spill passage efficiency ${ }^{1}$ and effectiveness, sluice passage efficiency and effectiveness, and fish passage efficiency on a seasonal and daily basis.

- Daily fish passage efficiency was variable ranging from 0.5 to 0.98 for the spillway and from 0.0 to 0.2 for the sluiceway (Table S.1). Passage efficiencies dipped in late May and early June. Spill passage dominated total project fish passage efficiency.

\footnotetext{
${ }^{1}$ By definition, "efficiency" is the proportion of fish passing a given route and "effectiveness" is the fish:flow ratio (proportion fish divided by proportion water through a particular route).
} 
- Daily sluiceway effectiveness relative to the project as a whole ranged from 0 to 9.98 . Sluiceway effectiveness relative to the powerhouse ranged from 0 to 23.93. Sluiceway effectiveness was variable from day to day with a declining trend during the total study period.

Table S.1. Seasonal passage efficiency and effectiveness metrics with $95 \%$ confidence intervals at The Dalles Dam as measured with hydroacoustics in 2004.

\begin{tabular}{|l|c|c|}
\hline & Spring (4/19-6/5) & Summer (6/6-7/11) \\
\hline Fish Passage Efficiency & $0.910 \pm 0.003$ & $0.819 \pm 0.005$ \\
\hline Spill Efficiency & $0.839 \pm 0.006$ & $0.780 \pm 0.006$ \\
\hline Spill Effectiveness & $2.13 \pm 0.01$ & $2.00 \pm 0.05$ \\
\hline Sluice Efficiency & $0.071 \pm 0.005$ & $0.039 \pm 0.004$ \\
\hline Sluice Efficiency re: phs & $0.442 \pm 0.019$ & $0.179 \pm 0.015$ \\
\hline Sluice Effectiveness & $3.25 \pm 0.22$ & $1.65 \pm 0.16$ \\
\hline Sluice Effectiveness re: phs & $12.19 \pm 0.59$ & $4.58 \pm 0.46$ \\
\hline re: phs $=$ relative to powerhouse \\
\hline
\end{tabular}

Estimate vertical, horizontal, and diel fish distributions at the powerhouse and spillway.

- The vertical distribution of fish at the powerhouse turbine intakes and the spillway was deeper during summer than spring. At the powerhouse intakes, fish were deeper during night than day in spring, whereas the opposite was true for summer. At the spillway, fish were deeper during day than night during both spring and summer.

- At the powerhouse, the horizontal distribution showed fish passage was highest at SL 1 and MU 8 during spring. During summer, passage at the powerhouse was fairly uniform, with highest passage at MU 8. The horizontal distribution was not skewed to the east during summer, as observed in previous studies.

- At the spillway, the horizontal distribution of fish passage was highest at Bay 6 and Bay 2 during spring. During summer, passage at the spillway was fairly uniform, with highest passage at Bays 2 and 3. Bays 7-10 were not typically opened, but when they were, fish passed there.

- The diel distribution of passage was much more variable during summer than spring. During spring, passage at the powerhouse turbine intakes peaked at dusk while sluiceway and spillway passage was relatively uniform. During summer, powerhouse turbine intake passage was highest during 2300-2400 h, sluiceway passage peaked during daytime, and spillway passage was greatest at dawn.

- At Spill Bay 5, fish passage data from the three split-beam transducers deployed there were analyzed to describe the combined vertical and horizontal distribution of passage. During day in spring and summer, passage was relatively high in a band across the entire bay, although this layer was at El. 129-137 ft in spring and El. 122-127 ft in summer. The 
distribution of passage at Bay 5 varied between day and night and between spring and summer.

Analyze the effect of sluiceway skimmer gate operation on fish passage into the sluiceway. Treatments will include open gates in the west only (MU 1-1, 1-2, 1-3) and in the west and east (MU $1-1,1-2,1-3,18-1,18-2,18-3)$ regions of the powerhouse.

- Opening east end gates increased total sluice passage over that for the west gates alone. For the study as a whole, total sluice passage was $11 \%$ higher in spring and $65 \%$ higher in summer with the east gates (SL 18) open than with the west gates (SL 1) alone. For only times when the West+East treatment was in place, total sluice passage was $21 \%$ higher in spring and $221 \%$ higher in summer with the east gates (SL 18) open than with the west gates (SL 1) alone. The results, however, usually were not statistically significant.

- Opening the east end sluice contributed 4 percentage points of the total $44 \%$ sluice efficiency at the powerhouse in spring and 7 percentage points of the total $17 \%$ sluice efficiency (re: powerhouse) in summer. In both day and night periods in spring and summer, sluiceway efficiency (re: powerhouse) was significantly $(\mathrm{P}<0.05)$ higher with the West+East treatment than the West only treatment.

- Opening sluice gates at the east end of the dam (SL 18) reduced turbine passage at the eastern part of the dam (MU 17 to MU 22), but the results were not generally statistically significant $(\mathrm{P}>0.10)$. In 3 of 4 combinations of treatment and season for day/night separately, east turbine passage during the treatment with the east end sluice gates open (West+East) was lower than during the treatment with the east sluice gates closed (West).

- The horizontal distribution data indicated passage into the west sluice gates (SL1) generally was not lower during the West+East treatment than the West treatment. If such was the case, it would indicate that opening the east end gates would not be a benefit because the fish that went in the east sluiceway entrance may have used the west entrance.

Describe sluiceway nearfield fish movements and integrate those data and sluiceway passage data with hydraulic data.

- The sluiceway zone of influence is the region immediately upstream of a sluice entrance where juvenile salmonids have a high probability of ultimately moving into the sluiceway. Data from the tracking effort using the acoustic camera in the nearfield of SL 1-3 and SL 183 showed the zone of influence was about 20-25 ft.

- Smolts displayed positive rheotaxis in the nearfield of the sluiceway. We also often saw schools of juvenile salmonids, as opposed to individual fish, moving into the sluiceway entrances.

- In general, juvenile salmonid movement patterns did not differ appreciably between the two sluice entrances. Fish approached from the east and northeast, some moved toward and into the sluice entrance while others continued west.

- The location of the observed sluiceway zone of influence corresponded with the location of the sluiceway flow net. 
- Hourly sluice efficiency (re: powerhouse) data did not reveal any adverse effects from power peaking as indicated by total hourly powerhouse discharge and the difference in total discharge between successive hours.

- The relationship between sluiceway fish passage efficiency and sluice discharge proportion was positive for the powerhouse as a whole and for the east end sluice, but it was negative for the west end sluice.

The last objective involved recommendations for the sluiceway at The Dalles Dam.

Provide recommendations for sluiceway operations and long-term measures to enhance sluiceway and spillway passage and reduce turbine passage.

- We recommend six rather than three sluice gates be opened to take advantage of the maximum hydraulic capacity of the sluiceway.

- In 2005, we recommend the Corps and fisheries agencies consider operating sluice gates in one or more of the following combinations of six gates:

o SL 1-1, 1-2, 1-3 and SL 18-1, 18-2, 18-3 (repeat 2004 operation)

o SL 1-1, 1-2, 1-3 and SL 11-1, 11-2, 11-3

o SL 1-1, 1-2, 1-3 and SL 2-1, 2-2, 2-3.

- Whenever a sluice gate is open the turbine unit below it should be operated as standard fish operations procedure.

- The following elements for surface flow bypasses should be considered during design of any sluiceway enhancements at The Dalles Dam:

o Form an extensive surface flow bypass flow net (surface bypass discharge greater than $\sim 7 \%$ of total project discharge).

o Create a gradual increase in water velocity approaching the surface flow bypass (ideally, acceleration $<1 \mathrm{~m} / \mathrm{s}$ per meter).

o Make water velocities at an entrance high enough $(>3 \mathrm{~m} / \mathrm{s})$ to entrain the subject juvenile fishes.

0 Adapt the shape and orientation of the surface entrance(s) to fit site-specific features.

o Consider installing a forebay wall to increase fish availability to the surface flow bypass.

- The Dalles Dam sluiceway has potential to be highly efficient and effective at passing juvenile salmonids. We recommend tapping this potential with enhancements to the sluiceway. 


\section{Preface}

This research was conducted under the auspices of the U.S. Army Corps of Engineers, Northwestern Division's Anadromous Fish Evaluation Program (AFEP), Columbia River Fish Mitigation Project. The research pertains to AFEP study codes SPE-P-00-8 and SBE-P-00-017. It is related to and complements spill passage and surface flow bypass research at other dams in the Federal Columbia River Power System (study codes SBE-W-96-1, SBE-W-96-2, SBE-P-00-6, and SBE-P-00-13). This study was funded by the Portland District, U.S. Army Corps of Engineers under a contract with the Pacific Northwest National Laboratory, operated by Battelle for the U.S. Department of Energy. Subcontractors to Battelle included Tenera Environmental (No. 412266-BB8), and the University of Washington (No. 412267-B-B8). BAE Systems, Inc. was contracted separately by the Portland District to participate in this study.

\section{Acknowledgments}

We earnestly acknowledge contributions to this study by:

- U.S. Army Corps of Engineers fisheries biologists: Dan Feil and Bernard Klatte

- U.S. Army Corps of Engineers personnel - Bob Cordie, Steve Dingman, Sue Fox, Dick Harrison, Don Hibbs, Larry Lawrence, Paul Ocker, Rock Peters, Norm Tolonen, and Miro Zyndol

- $\quad$ Battelle staff - Dennis Dauble, Al Garcia, Terri Gilbride, Kenneth Ham, Kathy Lavender, Nate Phillips, Gene Ploskey, Kathi Ruiz, Scott Titzler, and Mark Weiland

- $\quad$ BAE Systems, Inc. - Kyle Bouchard, Charlie Escher, Chris Holzer, Peter Johnson, Jane Marquard, Joe Mullen, Deborah Patterson, and Carl Schilt

- $\quad$ Honald Crane Services - Bob Austin and Mike Honald

- Schlosser Machine Shop - Vinnie Schlosser and staff

- University of Washington, Applied Physics Laboratory - Ed Belcher and Bill Hanot

- University of Washington, Columbia Basin Research - Cindy Helfrich and Jim Lady. 
Hydroacoustic Evaluation of Juvenile Salmonid Passage at The Dalles Dam in 2004 


\section{Contents}

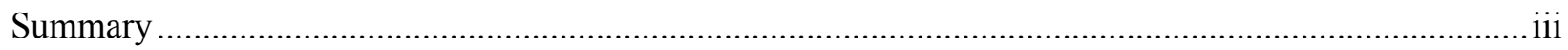

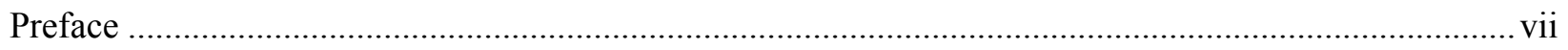

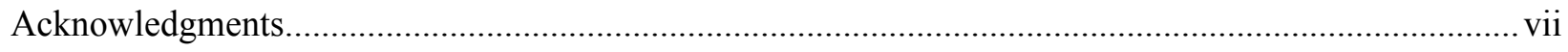

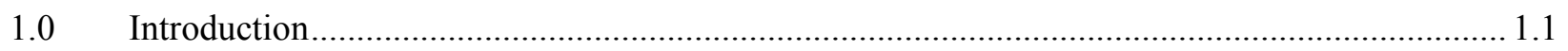

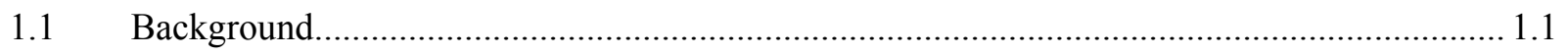

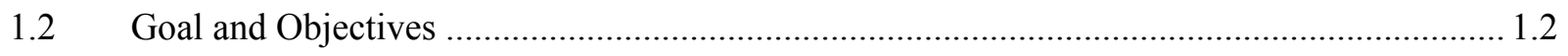

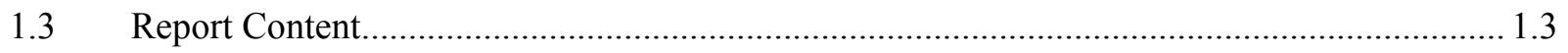

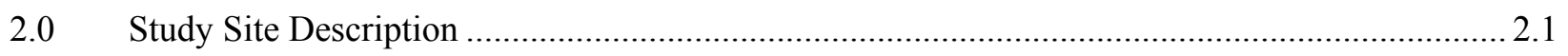

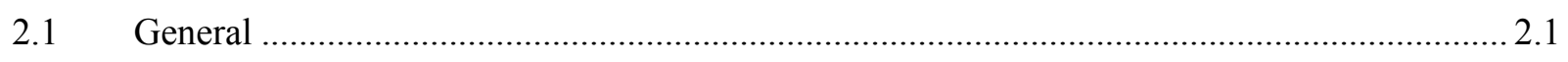

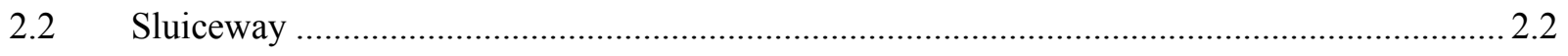

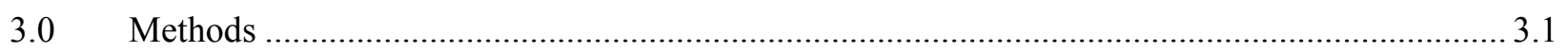

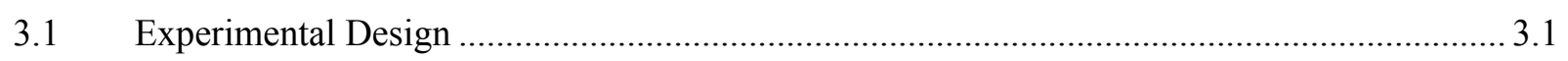

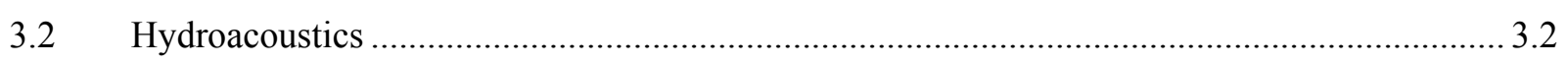

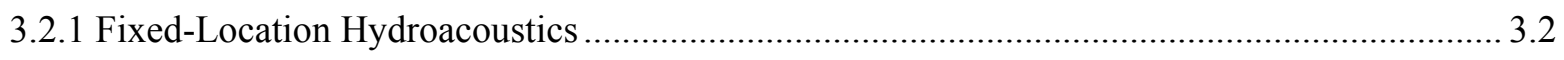

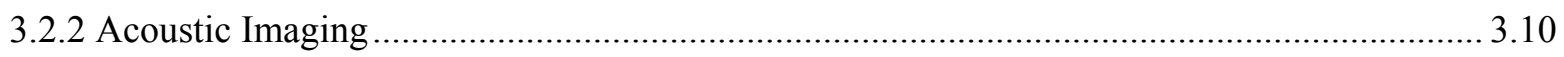

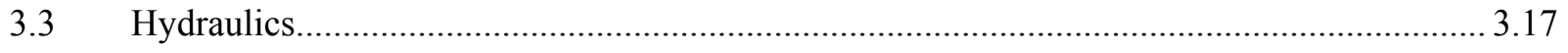

3.3.1 Computational Fluid Dynamics Model........................................................................... 3.17

3.3.2 Acoustic Doppler Current Profilers …….............................................................................. 3.18

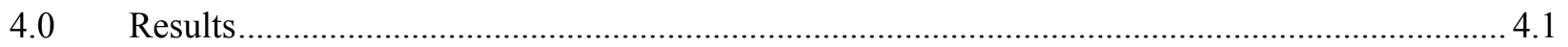

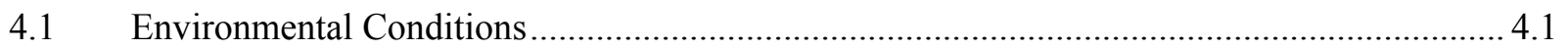

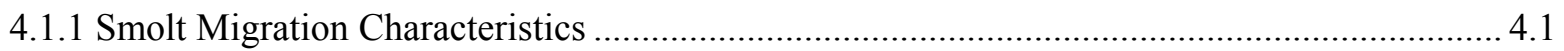

4.1.2 River Discharge, Forebay Elevation, Temperature, and Turbidity ...................................... 4.2

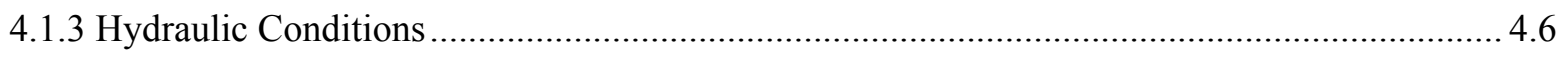

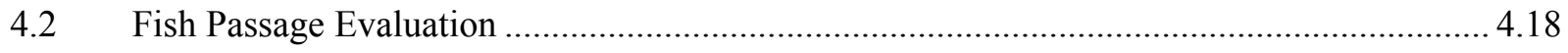

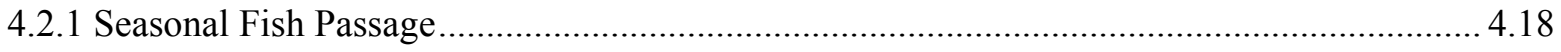

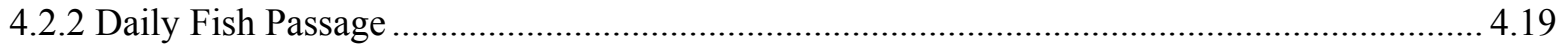

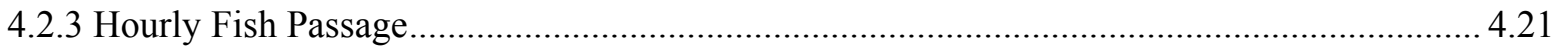

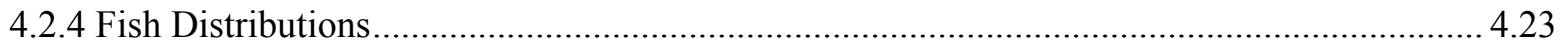

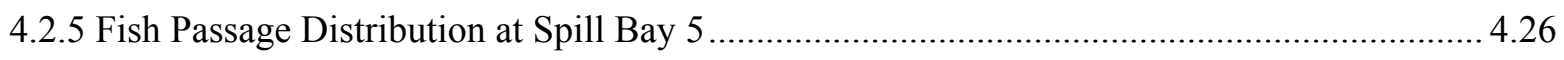

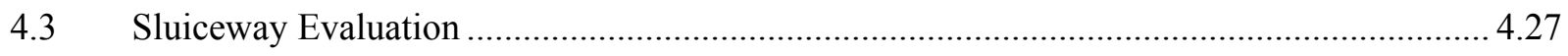




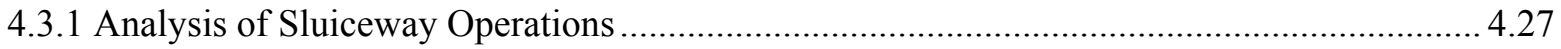

4.3.2 Integration of Fish Movement and Passage Data with Hydraulic Data ................................. 4.30

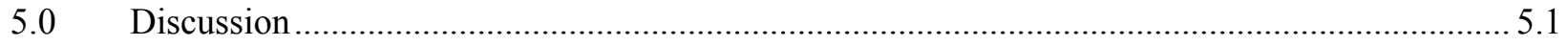

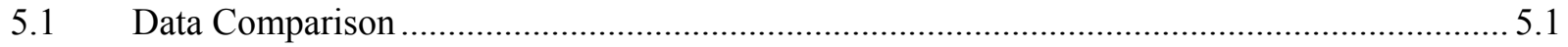

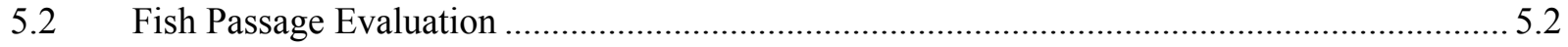

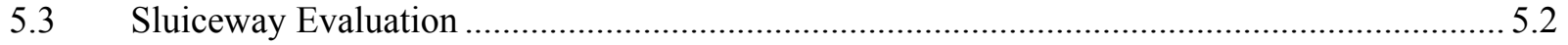

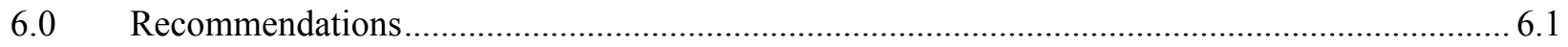

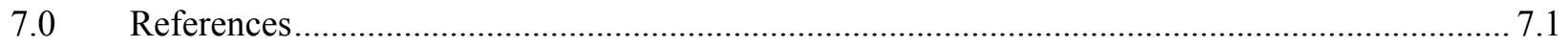

Appendix A: Statistical Synopsis for the 2004 Fixed-Location Hydroacoustic Investigations

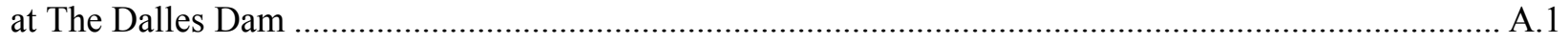

Appendix B: Directionality Analysis of the 2004 The Dalles Dam DIDSON Tracking Data....................1 


\section{Figures}

Figure 1.1. Aerial Photograph of The Dalles Dam. Flow is from left to right..................................... 1.1

Figure 2.1. Plan View of The Dalles Dam Showing Forebay Bathymetry..........................................2.1

Figure 3.1. Plan View of The Dalles Dam Showing Transducer Locations. ........................................... 3.4

Figure 3.2. Cross-Sectional View of a Main Unit Transducer Deployment. .......................................... 3.5

Figure 3.3. Cross-Sectional View of a Fish Unit Transducer Deployment.............................................. 3.6

Figure 3.4. Deployment for a Side-Looking Sluiceway Transducer Mounted on a Steel I-Beam

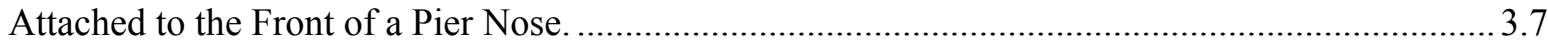

Figure 3.5. Deployment for a Side-Looking Sluiceway Transducer mounted on "J" Occlusion

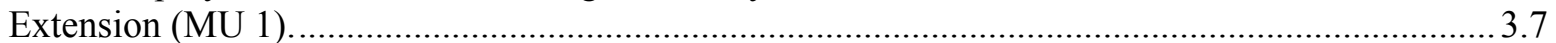

Figure 3.6. Top View of Transducer Deployment for SL 1 ................................................................... 3.8

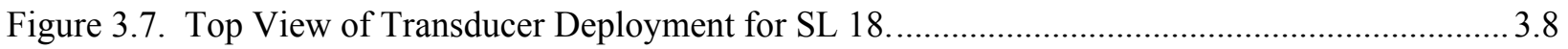

Figure 3.8. Cross-Sectional View of a Spill Bay Transducer Deployment............................................. 3.9

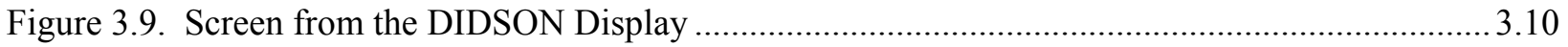

Figure 3.10. Electric Hoist and Davit System Used to Deploy the DIDSON........................................12

Figure 3.11. DIDSON Mounted to Pan and Tilt Rotator and Trolley.....................................................12

Figure 3.12. Plan View Showing the DIDSON Sampling Location at SL 1 . .....................................13

Figure 3.13. Fates where fish movements were absorbed at edges of the sample volume are as follows: Sluiceway, East, West, and Reservoir.......................................................................15

Figure 3.14. Cross-Sectional View of a Powerhouse ADCP Deployment. ............................................3.19

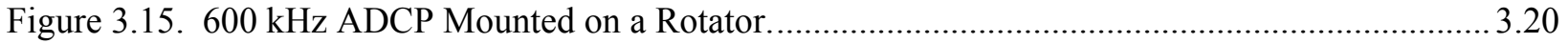

Figure 3.16. Schematic of the ADCP Deployment at the Spillway....................................................2.

Figure 4.1. Smolt Monitoring Program (SMP) Passage Index for April 19 - July 17, 2004,

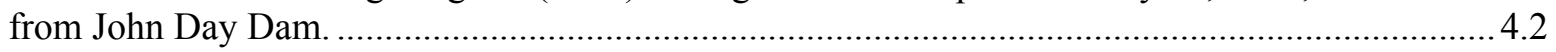

Figure 4.2. Daily Total Outflow and Spill for 2004 and the 10-yr Average (kcfs)..............................4.3

Figure 4.3. Diel Distribution of Total Project Discharge for Spring (4/19-6/5) and

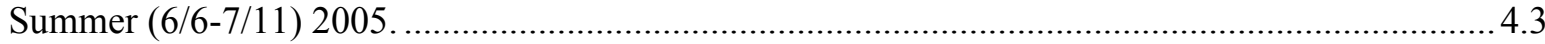

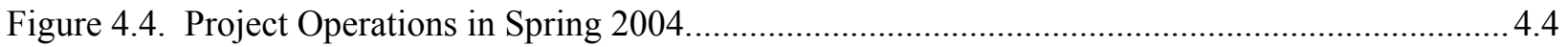

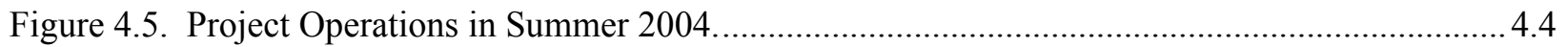

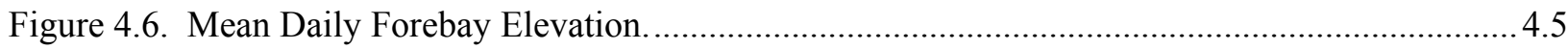

Figure 4.7. Mean Daily Temperature and Turbidity for April 19 - July 17, 2004, at TDA.................. 4.5

Figure 4.8. Plan View of the Forebay Velocities from a CFD Model .................................................. 4.6

Figure 4.9. Side View of the Forebay Velocities from a CFD Model................................................... 4.7 
Figure 4.10. Plan View of CFD Data for the Forebay of Sluice 1-3

during the West-Only Treatment.

Figure 4.11. Velocities in Beam 1 (pointed 9 degrees down) at The Dalles Dam

MU 1 sluiceway, May 25-27, 2004.

Figure 4.12. Velocities in Beam 1 (pointed 9 degrees down) at The Dalles Dam MU 1 sluiceway, June 8-10, 2004.

Figure 4.13. Velocities in Beam 1 (pointed 9 degrees down) at The Dalles Dam MU 1 sluiceway, June 28-30, 2004.

Figure 4.14. Velocities in Beam 1 (pointed 9 degrees down) at The Dalles Dam MU 18 sluiceway, May 27-28, 2004.

Figure 4.15. Velocities in Beam 1 (pointed 9 degrees down) at The Dalles Dam MU 18 sluiceway, June 7-8, 2004.

Figure 4.16. Velocities in Beam 1 (pointed 9 degrees down) at The Dalles Dam MU 18 sluiceway, June 30 to July 1, 2004.

Figure 4.17. Average Velocities in ADCP Beam 1 (pointed 9 degrees down and 33 degrees out upstream) at The Dalles Dam MU 1 Sluiceway, May 25-27, 2004

Figure 4.18. Average Velocities in ADCP Beam 1 (pointed 9 degrees down and 33 degrees out upstream) at The Dalles Dam MU 1 Sluiceway, June 8-10, 2004

Figure 4.19. Average Velocities in ADCP Beam 1 (pointed 9 degrees down and 33 degrees out upstream) at The Dalles Dam MU 1 Sluiceway, June 28-30, 2004

Figure 4.20. Average Velocities in ADCP Beam 1 (pointed 9 degrees down and 33 degrees out upstream) at The Dalles Dam MU 18 Sluiceway, May 27-July 1, 2004...

Figure 4.21. Beam 1 Velocities at $10 \mathrm{~m}$ from the ADCP at MU1 Sluiceway over Three Data Periods

Figure 4.22. Beam 1 Velocities at $10 \mathrm{~m}$ from the ADCP at MU18 Sluiceway over Three Data Periods.

Figure 4.23. Side View of a Spill Bay with CFD Results Showing Velocity along Beams in ft/s ........ 4.16

Figure 4.24. Comparison of ADCP and CFD velocity data at Spill Bay 5 ......................................... 4.17

Figure 4.25. Close-up of Narrow Magnitude Velocity Range Corresponding to Figure 4.24..............4.17

Figure 4.26. Example of Applying a CFD Model at the Spillway..................................................... 4.18

Figure 4.27. Fish Passage Indices for The Dalles Dam in 2004 ........................................................ 4.19

Figure 4.28. Daily Passage Efficiencies at The Dalles Dam in 2004 ....................................................4.20

Figure 4.29. Daily Passage Effectiveness at The Dalles Dam in 2004 .................................................21

Figure 4.30. Hourly Spill Efficiency vs. Spill Discharge (cfs) for Spring and

Summer Combined...

Figure 4.31. Hourly Spill Efficiency vs. Spill Discharge Proportion for Spring and Summer Combined. 
Figure 4.32. Vertical Distributions at the Powerhouse Turbine Intakes and Spillway for

Day and Night in Spring and Summer in 2004

Figure 4.33. Horizontal Distributions at the Powerhouse and Spillway in Spring and Summer in 2004.

Figure 4.34. Diel Distributions at the Powerhouse Turbine Intakes, Spillway, Sluice 1, and Sluice 18 in Spring (top figure) and Summer (bottom figure) in 2004.

Figure 4.35. Front View of Bay 5 Showing Contours of Relative Fish Passage Rates for Spring and Summer 2004, Day and Night

Figure 4.36. Total Sluiceway Passage by Block by Treatment (West and West+East) for The Dalles Dam in Spring 2004.

Figure 4.37. Total Sluiceway Passage by Block by Treatment (West and West+East) for The Dalles Dam in Summer 2004.

Figure 4.38. Horizontal Distribution of Passage into Open Sluice Gates by Sluice Treatment (West vs West+East) at The Dalles Dam in 2004. 30

Figure 4.39. Horizontal Distribution of Passage into Open Sluice Gates by Day/Night at The Dalles Dam in 2004.

Figure 4.40. Example Individual/School Fish Tracks from May 13, 2004 for SL 1

Figure 4.41. Contours of Fate Probabilities for Passage at The Dalles Dam, SL 1 and 18 for Spring and Summer 2004

Figure 4.42. Generalized Fish Track Grid Superimposed on Water Velocity Magnitudes at SL 1 and SL 18

Figure 4.43. Relationship between Total Powerhouse Discharge and Sluiceway Efficiency (re: powerhouse) for West and West+East Sluice Treatments for Hourly Hydroacoustic Data for Spring and Summer Combined at The Dalles Dam in 2004.

Figure 4.44. Relationship between Delta Powerhouse Discharge (hourly difference) and Sluiceway Efficiency (re: powerhouse) for West and West+East Sluice Treatments for Hourly Hydroacoustic Data for Spring and Summer Combined at The Dalles Dam in 2004.

Figure 4.45. Relationship between the Absolute Value of Delta Powerhouse Discharge (hourly difference) and Sluiceway Efficiency (re: powerhouse) for West and West+East Sluice Treatments for Hourly Hydroacoustic Data for Spring and Summer Combined at The Dalles Dam in 2004.

Figure 4.46. Relationship between Proportion of Total Sluice Discharge Out of Total Powerhouse Discharge and Sluiceway Efficiency (re: powerhouse) for West and West+East Sluice Treatments for Hourly Hydroacoustic Data for Spring and Summer Combined at The Dalles Dam in 2004.

Figure 4.47. Relationship between Proportion of West Sluice (SL1) Discharge Out of West (FU1 to MU5) Powerhouse Discharge and Sluiceway Efficiency (re: west powerhouse) for West and West+East Sluice Treatments for Hourly Hydroacoustic Data for Spring and Summer Combined at The Dalles Dam in 2004.

Figure 4.48. Relationship between Proportion of East Sluice (SL18) Discharge Out of East (MU17 to MU22) Powerhouse Discharge and Sluiceway Efficiency (re: east powerhouse) for the 
West+East Sluice Treatment for Hourly Hydroacoustic Data for Spring and Summer Combined at The Dalles Dam in 2004.

\section{Tables}

Table 2.1. Hydraulic Calculations for the Sluiceway at The Dalles Dam: West only. 2.2

Table 2.2. Hydraulic Calculations for the Sluiceway at The Dalles Dam: West+East.

Table 3.1. Randomized, Block Sample Design for Spring and Summer Sluice Treatments at the Dalles Dam, 2004

Table 3.2. Sample Locations and Spatial Sampling Intensity at The Dalles Dam in 2004.

Table 3.3. DIDSON Sampling Schedule.

Table 3.4. Scenarios for CFD Modeling

Table 3.5. Spillway Operations Sampled by ADCP.

Table 4.1. Data Blocks Used in ADCP Analysis at The Dalles Dam, May 25 to July 1, 2004.

Table 4.2. Seasonal Fish Passage Metrics for The Dalles Dam in 2004.

Table 4.3. Analysis of the Benefits of East End Sluice Gate Operation by Season at The Dalles Dam in 2004

Table 4.4. Sluiceway Efficiencies Relative to Total Powerhouse Passage for West (SL 1), East (SL 18), and Total (SLY) Sluice Routes by Treatment and Season at The Dalles Dam in 2004.

Table 4.5. East Turbine Passage (MU 17-22) by Day/Night, Treatment, and Season at The Dalles Dam in 2004

Table 4.6. Relative Fates Probabilities of Passage.

Table 5.1. Proportion of Total Sluiceway Passage for SL 1 and SL 18 and Sluiceway Efficiencies (SLY) by Season Separately for Hydroacoustics (HA) and Radio Telemetry (RT) Studies at The Dalles Dam in 2004.

Table 5.2. Mean Hourly Passage Rates at the West (SL1) and East (SL18) Sluice Entrances by Operation of Main Units Below and Adjacent to the Open Sluice. 


\subsection{Introduction}

Development of long-term measures to protect juvenile salmon at The Dalles Dam (Figure 1.1) is a high priority in the endeavor to increase salmon smolt survival through the Federal Columbia River Power System (FCRPS) (National Marine Fisheries Service 2000). Juvenile salmonids pass The Dalles Dam (TDA) through one of three routes: turbines, spillway, or sluiceway. In 2004, the US Army Corps of Engineers (COE) Portland District contracted Pacific Northwest National Laboratory (PNNL) to evaluate fish passage via these three routes using hydroacoustics. The goal of the study was to provide information on smolt passage at The Dalles Dam to inform decisions on long-term measures and operations to enhance sluiceway and spill passage and to reduce turbine passage in order to improve smolt survival at the dam.

\subsection{Background}

The multi-faceted strategy to improve smolt survival at TDA involves all three passage routes: turbine, spillway, and sluiceway. At the turbines, intake occlusions were tested in 2001 and 2002 to determine if blocking the upper half of the turbine intakes at the trash racks might significantly reduce turbine entrainment. Results from this research indicated that the occlusions were generally not effective at reducing turbine passage (Johnson et al. 2003; Hausmann et al. 2004). At the spillway, survival of downstream migrants is typically lower than at other projects on the lower Columbia River (Ploskey et al. 2001a). In an effort to improve survival of spilled fish, a wall dividing the spillway between Bays 6 and 7 was installed prior to the 2004 juvenile salmonid migration season and a bulk spill pattern at Bays 1-6 was adopted. Bioengineering is currently underway to design a floating wall in the forebay to divert juvenile salmonids from the powerhouse to the spillway; this effort is applying results from forebay distribution and migration pathway studies by Cash et al. (2005) and Faber et al. (2005). At the sluiceway, an alternative means of operating the entrance gates may provide additional protection for juvenile salmonids at the TDA powerhouse.

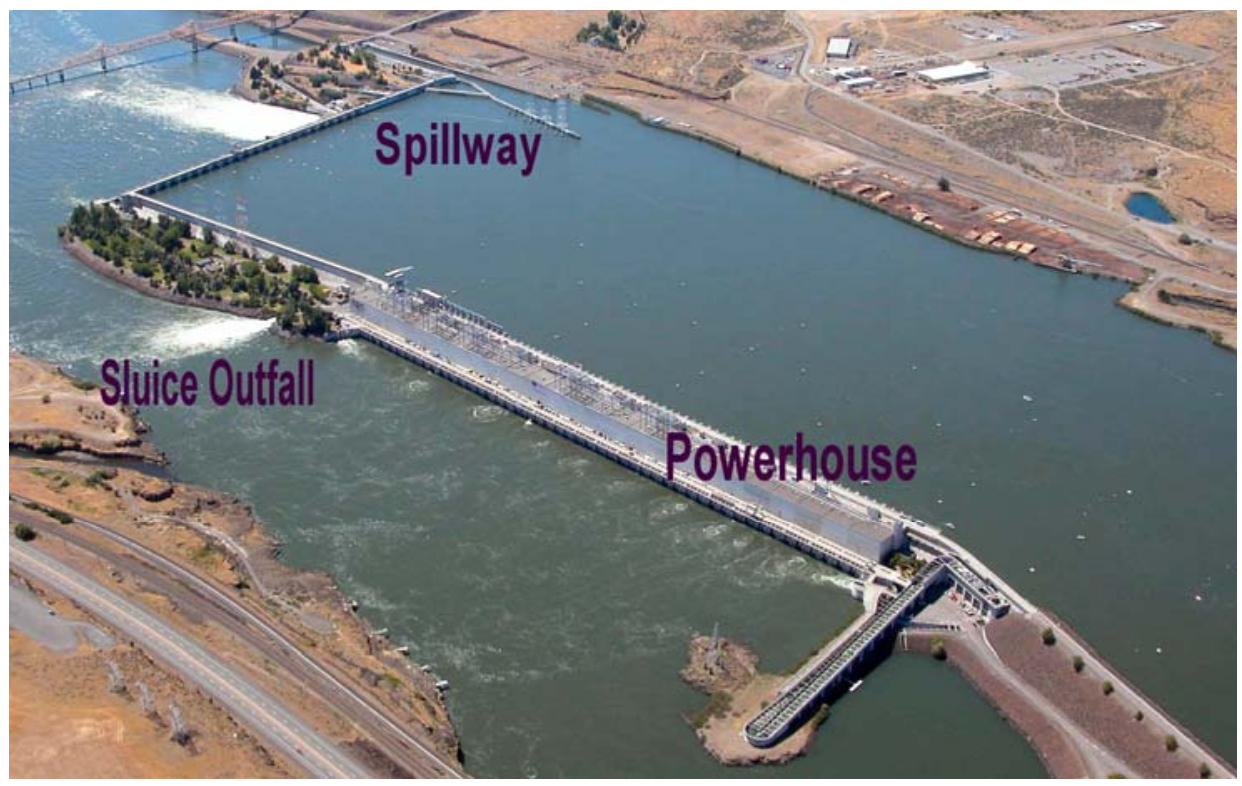

Figure 1.1. Aerial Photograph of The Dalles Dam. Flow is from right to left. 
The sluiceway at The Dalles Dam is a functional surface flow bypass. Current sluiceway operations were essentially established from mark-recapture studies using sluiceway fyke nets in the late 1970s and early 1980s (Nichols 1979 and 1980; Nichols and Ransom 1981 and 1982). In 1978, Nichols (1979) found that the sluice gates at the west end of the powerhouse had higher yearling salmon passage rates than did gates in the middle. In 1979, Nichols (1980) reported sub-yearling passage was significantly higher at Units 17 and 18 than at Units 1 and 2, but in 1980, Nichols and Ransom (1981) reported no significant difference. Nichols (1980) recommended that the sluiceway be operated $24 \mathrm{~h} / \mathrm{d}$ because noticeable numbers of smolts used the sluiceway at night, although highest passage was during daylight hours. Based on these data, fisheries managers recommended that the sluice gates above Main Unit 1 be open $24 \mathrm{~h} / \mathrm{d}$ to pass juvenile salmonids during spring and summer. The Dalles Dam sluiceway has been operated this way for the last 24 years.

However, fish approach and horizontal distribution data from 1997-2002, the fyke net data for sub-yearlings (Nichols 1980), and new hydraulic calculations point to the need to confirm that a west end sluice operation is optimal for both spring and summer emigrants. For example, in 1997 researchers using radio telemetry first detected about $60 \%$ of the steelhead and $56 \%$ of the yearling Chinook salmon entering the forebay off the eastern end of the powerhouse (Hensleigh et al. 1999). This pattern was consistent with other radio telemetry studies at The Dalles Dam (Sheer et al. 1997; Holmberg et al. 1997; Hansel et al. 2000; Beeman et al. 2004; Hansel et al. 2005). Recent hydroacoustic studies have shown that the distribution of fish passage at the powerhouse was uniform or skewed toward the west end in spring but skewed toward the east end in summer (Ploskey et al. 2001b; Moursund et al. 2001; Moursund et al. 2002; Johnson et al. 2003). Furthermore, Nichols (1980) found higher passage for marked subyearling salmon at the east end sluice (SL 17 and 18) than the west end (SL 1 and 2), although in a repeat study Nichols and Ransom (1981) reported no significant difference between east and west sluice passage. In 2003, engineers determined that the sluiceway at The Dalles Dam is at less than maximum hydraulic capacity when only the three chain gates above Main Unit 1 are open. That is, additional gates can be opened before the maximum hydraulic capacity of the sluiceway channel is reached ( 4,600 cfs). Collectively, the biological and engineering studies provided an impetus for renewed sluiceway operations research.

Therefore, the hydroacoustic study at The Dalles Dam in 2004 was driven by the need to provide juvenile salmonid passage data for the purposes of the Spillway Improvements and Surface Flow Bypass programs.

\subsection{Goal and Objectives}

The goal of this study was to provide information on juvenile salmonid passage at The Dalles Dam that can be used by the Corps of Engineers and fisheries resource managers to make decisions on long-term measures to enhance sluiceway and spillway passage and reduce turbine passage in order to increase smolt survival rates at the dam. The objectives of the study, organized into a fish passage evaluation for the Spillway Improvement Program and a sluiceway evaluation for the Surface Flow Bypass Program, were as follows:

\section{Fish Passage Evaluation}

1. Estimate spill passage efficiency and effectiveness ${ }^{1}$, sluice passage efficiency and effectiveness,

\footnotetext{
${ }^{1}$ By definition, "efficiency" is the proportion of fish passing a given route and "effectiveness" is the fish:flow ratio (proportion of fish divided by proportion of water through a particular route).
} 
and fish passage efficiency on a seasonal and daily basis.

Efficiency and effectiveness estimates from hydroacoustics are used to summarize fish passage for the run-at-large during the spring and summer migration seasons. Because similar methods have been applied in the last five years at The Dalles Dam, the metrics can be compared across years. This provides fisheries resource managers with data on trends and patterns in fish passage to make decisions on project operations and fish protection design efforts.

2. Estimate vertical, horizontal, and diel fish distributions at the powerhouse and spillway.

Fish distribution is fundamental to a fish passage evaluation. Distribution data are also used to aid design of project operations and structures intended to increase juvenile salmonid survival.

\section{Sluiceway Evaluation}

3. Analyze the effect of sluiceway skimmer gate operation on fish passage into the sluiceway. Treatments will include open sluice (SL) gates in the west (SL 1-1, 1-2, 1-3) and in the west and east (SL 1-1, 1-2, 1-3, 18-1, 18-2, 18-3) regions of the powerhouse.

This study compares fish passage under the typical sluiceway operation (west gates only) with fish passage under an alternate method of sluiceway operation (west and east gates open).

4. Describe sluiceway nearfield fish movements and integrate those data and sluiceway passage data with hydraulic data.

Previous studies used fish movement data to determine the zone of influence for the sluiceway flow net (Hedgepeth et al. 2002a, 2002b; Johnson et al. 2004). These studies, however, did not analytically integrate the fish movement data with hydraulic data because the appropriate hydraulic data became available after the studies were completed. Given the hydraulic tools now available and advanced imaging sonar methods (acoustic camera) to track fish in the nearfield of the sluiceway $(<30 \mathrm{ft})$, this study provides improved understanding of fish behavior for the purpose of designing methods to enhance sluiceway passage.

5. Provide recommendations for sluiceway operations and long-term measures to enhance sluiceway and spillway passage and to reduce turbine passage.

It is important to discuss and interpret the collective information from this study and others as it pertains to short- and long-term smolt protection measures at The Dalles Dam.

\subsection{Report Content}

This report has seven sections and two appendices. Following the introduction in Section 1, the study site description is in Section 2. Section 3 contains the study methods. Section 4 has the results of the fish passage and sluiceway evaluations. Section 5 provides discussion of the results. Section 6 contains recommendations. Section 7 lists the literature cited. Appendix A contains a synopsis of the statistical methods. Appendix B is a report on an analysis of directionality of fish tracked by the acoustic camera for the sluiceway evaluation. 
Hydroacoustic Evaluation of Juvenile Salmonid Passage at The Dalles Dam in 2004 


\subsection{Study Site Description}

\subsection{General}

The Dalles Dam (Figure 1.1), located at river mile 192, is the second closest dam to the Pacific Ocean in the Federal Columbia River Power System. Full pool elevation is rated at $160 \mathrm{ft}$ above mean sea level and minimum operating pool elevation is $155 \mathrm{ft}$. The thalweg intersects the dam at the eastern end of the powerhouse and there are deep areas in front of the powerhouse (Figure 2.1), although much of the forebay is relatively shallow ( $<65 \mathrm{ft}$ deep).

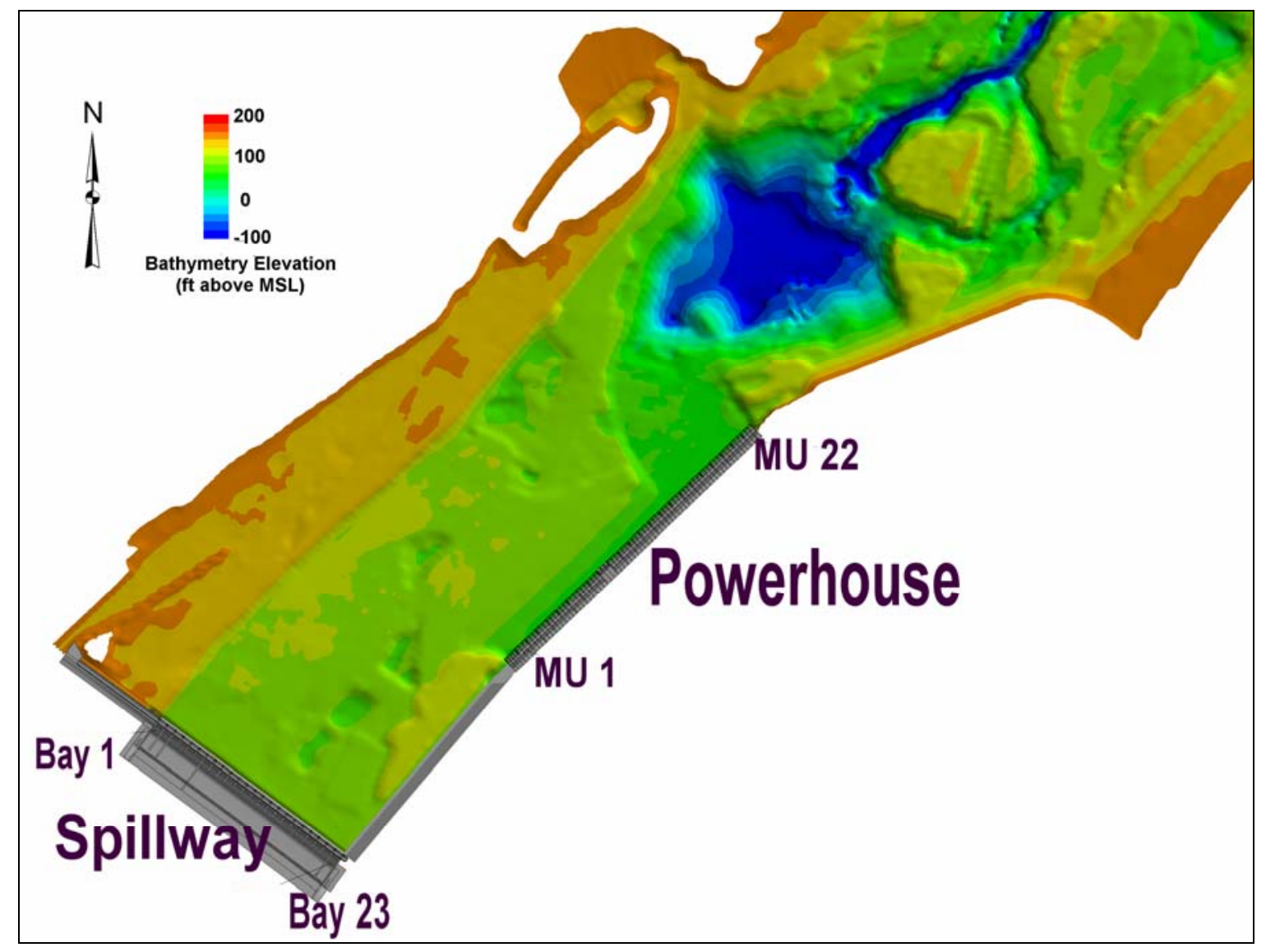

Figure 2.1. Plan View of The Dalles Dam Showing Forebay Bathymetry.

The Dalles Dam has a 2,090-ft-long powerhouse with 22 turbine units, a total generating capacity of 1,800 MW, and total powerhouse hydraulic capacity of $375 \mathrm{kcfs}$. The powerhouse also has two fish units at the west end that provide attraction flow to the fish ladder for upstream migrant adult salmonids. The face of the powerhouse is $11.3^{\circ}$ off vertical. The turbine intake ceiling intersects the trash racks at elevation $141 \mathrm{ft}$. The 1,380-ft-long spillway is comprised of 23 bays with radial gates $50 \mathrm{ft}$ wide. The spillway was modified during winter 2003-2004 to include a training wall that divides the stilling basin between Bays 6 and 7. New spill patterns were designed to place the bulk of spill discharge through Bays 1-6 during the 2004 study period. 


\subsection{Sluiceway}

The ice and trash sluiceway is a comprised channel that extends the entire length of the forebay side of the powerhouse (Figure 2.1). The sluiceway has three 20 -ft wide entrance gates positioned over each of the 22 turbine units. Water enters the sluiceway channel from the forebay when gates are moved off the sill at elevation $151 \mathrm{ft}$. A maximum of six sluice gates can be opened at any time before reaching the hydraulic capacity of the channel ( 4,600 cfs). Flow into the sluiceway is dependent on forebay elevation and the number and location of open gates. For example, given a forebay elevation equal to $158.4 \mathrm{ft}$ (above mean sea level) and two sluice gate operating conditions (see above), flows over the individual weir gates range from 561 to 1,059 cfs with highest flows at the west end nearest the sluiceway channel outlet (Tables 2.1 and 2.2).

Overall, sluiceway discharge is a relatively small proportion of total project discharge $(\sim 2 \%)$. During the juvenile fish passage season (April through November), typically only the three sluice gates at Main Unit (MU) 1 are opened. These gates are designated SL 1. However, as mentioned above, engineers determined that the sluiceway at The Dalles Dam is at less than maximum hydraulic capacity when only the three SL 1 gates are open, making it possible to open additional gates. In 2004, an alternative sluiceway operation was evaluated that entailed opening three additional sluice gates at SL 18. The two sluiceway treatments (gate openings) we tested were as follows:

- $\quad \mathrm{West}=1-1,1-2,1-3$

- $\quad$ West + East $=1-1,1-2,1-3,18-1,18-2,18-3$.

Table 2.1. Hydraulic Calculations for the Sluiceway at The Dalles Dam: West only (SL 1). Data provided by CENWP-Hydraulics.

\begin{tabular}{|c|c|c|c|c|}
\hline \multicolumn{5}{|c|}{ West Only Unit 1 Sluice Gates Open } \\
\hline \multicolumn{5}{|c|}{ Reservoir Level $=158.4 \mathrm{ft}$; Open Weir Elevation $=151.0 \mathrm{ft}$; Manning's Roughness $=0.014$} \\
\hline & & West & East & Total \\
\hline Sluice(s) Ope & & SL 1 & none & 1 \\
\hline No. Gates & & 3 & 0 & 3 \\
\hline \multicolumn{5}{|c|}{ Total Sluiceway Discharge $=3138 \mathrm{cfs}$} \\
\hline $\begin{array}{l}\text { Unit No. } \\
\text { (order from } \\
\text { d/s) }\end{array}$ & $\begin{array}{l}\text { Weir No. } \\
\text { (order from } \\
\mathrm{d} / \mathrm{s} \text { ) }\end{array}$ & $\begin{array}{l}\text { Q-weir flow over } \\
\text { weir (CFS) }\end{array}$ & $\begin{array}{c}\text { WS water level in } \\
\text { channel (ft) }\end{array}$ & $\begin{array}{l}\text { Ave Velocity } \\
\text { over weirs }\end{array}$ \\
\hline 1 & 1 & 1,059 & 146.6 & 7.2 \\
\hline 1 & 2 & 1,051 & 150.7 & 7.1 \\
\hline 1 & 3 & 1,029 & 152.0 & 7.0 \\
\hline Total & & 3,138 & & 7.1 \\
\hline
\end{tabular}


Table 2.2. Hydraulic Calculations for the Sluiceway at The Dalles Dam: West+East (SL1+SL18). Data provided by CENWP-Hydraulics.

\begin{tabular}{|c|c|c|c|c|}
\hline \multicolumn{5}{|c|}{ West + East Units $1 \& 18$ Sluice Gates Open } \\
\hline \multicolumn{5}{|c|}{ Reservoir Level $=158.4 \mathrm{ft}$; Open Weir Elevation $=151.0 \mathrm{ft}$; Manning's Roughness $=0.014$} \\
\hline & & West & East & Total \\
\hline Sluices Open & & SL 1 & SL 18 & 2 \\
\hline No. Gates & & 3 & 3 & 6 \\
\hline \multicolumn{5}{|c|}{ Total Sluiceway Discharge $=4451 \mathrm{cfs}$} \\
\hline \multicolumn{5}{|c|}{ Summary Weir Data } \\
\hline $\begin{array}{l}\text { Unit No. } \\
\text { (order from } \\
\mathrm{d} / \mathrm{s} \text { ) }\end{array}$ & $\begin{array}{l}\text { Weir No. } \\
\text { (order from } \\
\mathrm{d} / \mathrm{s} \text { ) }\end{array}$ & $\begin{array}{l}\text { Q-weir flow over } \\
\text { weir (CFS) }\end{array}$ & $\begin{array}{l}\text { WS water level in } \\
\text { channel (ft) }\end{array}$ & $\begin{array}{c}\text { Ave Velocity } \\
\text { over weirs }\end{array}$ \\
\hline 1 & 1 & 1,014 & 149.7 & 6.8 \\
\hline 1 & 2 & 876 & 154.0 & 5.9 \\
\hline 1 & 3 & 765 & 155.6 & 5.2 \\
\hline 18 & 4 & 645 & 156.7 & 4.4 \\
\hline 18 & 5 & 589 & 157.2 & 4.0 \\
\hline 18 & 6 & 561 & 157.4 & 3.8 \\
\hline Total & & 4,451 & & 5.0 \\
\hline
\end{tabular}


Hydroacoustic Evaluation of Juvenile Salmonid Passage at The Dalles Dam in 2004 


\subsection{Methods}

This section includes descriptions of the experimental design, hydroacoustic, and hydraulic methodologies.

\subsection{Experimental Design}

The hydroacoustic evaluation of the run at large at The Dalles Dam in 2004 was divided into spring (48 d, April 19 to June 5) and summer (42 d, June 6 to July 17) study periods. The seasonal periods were established by examining the 5 -year record of smolt passage indices from John Day Dam.

The two treatments in the sluiceway study: west only (SL 1-1, 1-2, and 1-3 open) and west and east (SL 1-1, 1-2, 1-3, 18-1, 18-2, and 18-3 open), were sampled according to a randomized, block design (Table 3.1). Each treatment lasted 1 day producing 2-day blocks. The April 19 to July 17 total study period consisted of 24 blocks during spring and 21 blocks during summer. A treatment day began at $0800 \mathrm{~h}$, with approximately $15 \mathrm{~min}$ required to change from one treatment to the other.

Table 3.1. Randomized, Block Sample Design for Spring and Summer Sluice Treatments at the Dalles Dam, 2004 (table continues on the next page)

\begin{tabular}{|c|c|c|c|c|c|c|c|c|c|}
\hline \multicolumn{10}{|c|}{2004 Spring Sluice Operations } \\
\hline $\begin{array}{l}\text { Study } \\
\text { Block }\end{array}$ & $\begin{array}{l}\text { Study } \\
\text { Day }\end{array}$ & $\begin{array}{l}\text { Summer } \\
\text { Date }\end{array}$ & $\begin{array}{l}\text { Day of } \\
\text { Week }\end{array}$ & $\begin{array}{l}\text { Sluice } \\
\text { Treatment }\end{array}$ & $\begin{array}{l}\text { Study } \\
\text { Block }\end{array}$ & $\begin{array}{l}\text { Study } \\
\text { Day }\end{array}$ & $\begin{array}{l}\text { Summer } \\
\text { Date }\end{array}$ & $\begin{array}{l}\text { Day of } \\
\text { Week }\end{array}$ & $\begin{array}{l}\text { Sluice } \\
\text { Treatment }\end{array}$ \\
\hline 1 & 1 & 19-Apr & Mon & SL 1 & 14 & 27 & 15-May & Sat & SL 1, SL 18 \\
\hline 1 & 2 & 20-Apr & Tue & SL 1, SL 18 & 14 & 28 & 16-May & Sun & SL 1 \\
\hline 2 & 3 & 21-Apr & Wed & SL 1, SL 18 & 15 & 29 & 17-May & Mon & SL 1 \\
\hline 2 & 4 & 22-Apr & Thur & SL 1 & 15 & 30 & 18-May & Tue & SL 1, SL 18 \\
\hline 3 & 5 & 23-Apr & Fri & SL 1, SL 18 & 16 & 31 & 19-May & Wed & SL 1, SL 18 \\
\hline 3 & 6 & 24-Apr & Sat & SL 1 & 16 & 32 & 20-May & Thur & SL 1 \\
\hline 4 & 7 & 25-Apr & Sun & SL 1, SL 18 & 17 & 33 & 21-May & Fri & SL 1 \\
\hline 4 & 8 & 26-Apr & Mon & SL 1 & 17 & 34 & 22-May & Sat & SL 1, SL 18 \\
\hline 5 & 9 & 27-Apr & Tue & SL 1 & 18 & 35 & 23-May & Sun & SL 1, SL 18 \\
\hline 5 & 10 & 28-Apr & Wed & SL 1, SL 18 & 18 & 36 & 24-May & Mon & SL 1 \\
\hline 6 & 11 & 29-Apr & Thur & SL 1, SL 18 & 19 & 37 & 25-May & Tue & SL 1, SL 18 \\
\hline 6 & 12 & 30-Apr & Fri & SL 1 & 19 & 38 & 26-May & Wed & SL 1 \\
\hline 7 & 13 & 1-May & Sat & SL 1 & 20 & 39 & 27-May & Thur & SL 1, SL 18 \\
\hline 7 & 14 & 2-May & Sun & SL 1, SL 18 & 20 & 40 & 28-May & Fri & SL 1 \\
\hline 8 & 15 & 3-May & Mon & SL 1 & 21 & 41 & 29-May & Sat & SL 1 \\
\hline 8 & 16 & 4-May & Tue & SL 1, SL 18 & 21 & 42 & 30-May & Sun & SL 1, SL 18 \\
\hline 9 & 17 & 5-May & Wed & SL 1 & 22 & 43 & 31-May & Mon & SL 1 \\
\hline 9 & 18 & 6-May & Thur & SL $1, \mathrm{SL} 18$ & 22 & 44 & 1-Jun & Tue & SL 1, SL 18 \\
\hline 10 & 19 & 7-May & Fri & SL 1 & 23 & 45 & 2-Jun & Wed & SL 1, SL 18 \\
\hline 10 & 20 & 8-May & Sat & SL 1, SL 18 & 23 & 46 & 3-Jun & Thur & SL 1 \\
\hline 11 & 21 & 9-May & Sun & SL 1, SL 18 & 24 & 47 & 4-Jun & Fri & SL 1 \\
\hline 11 & 22 & 10-May & Mon & SL 1 & 24 & 48 & 5-Jun & Sat & SL 1, SL 18 \\
\hline 12 & 23 & 11-May & Tue & SL 1, SL 18 & & & & & \\
\hline 12 & 24 & 12-May & Wed & SL 1 & & & & & \\
\hline 13 & 25 & 13-May & Thur & SL 1, SL 18 & & & & & \\
\hline 13 & 26 & 14-May & Fri & SL 1 & & & & & \\
\hline
\end{tabular}


Table 3.1 continued.

\begin{tabular}{|c|c|c|c|c|c|c|c|c|c|}
\hline \multicolumn{10}{|c|}{2004 Summer Sluice Operations } \\
\hline $\begin{array}{l}\text { Study } \\
\text { Block }\end{array}$ & $\begin{array}{l}\text { Study } \\
\text { Day }\end{array}$ & $\begin{array}{l}\text { Summer } \\
\text { Date }\end{array}$ & $\begin{array}{l}\text { Day of } \\
\text { Week }\end{array}$ & $\begin{array}{l}\text { Sluice } \\
\text { Treatment }\end{array}$ & Block & $\begin{array}{l}\text { Study } \\
\text { Day }\end{array}$ & $\begin{array}{l}\text { Summer } \\
\text { Date }\end{array}$ & $\begin{array}{l}\text { Day of } \\
\text { Week }\end{array}$ & $\begin{array}{l}\text { Sluice } \\
\text { Treatment }\end{array}$ \\
\hline 1 & 1 & 6 -Jun & Sun & SL 1 & 12 & 23 & 28-Jun & Mon & SL 1, SL 18 \\
\hline 1 & 2 & 7-Jun & Mon & SL 1, SL 18 & 12 & 24 & 29-Jun & Tue & SL 1 \\
\hline 2 & 3 & 8-Jun & Tue & SL 1, SL 18 & 13 & 25 & 30-Jun & Wed & SL 1, SL 18 \\
\hline 2 & 4 & 9-Jun & Wed & SL 1 & 13 & 26 & 1-Jul & Thur & SL 1 \\
\hline 3 & 5 & 10-Jun & Thur & SL 1, SL 18 & 14 & 27 & 2-Jul & Fri & SL 1, SL 18 \\
\hline 3 & 6 & 11-Jun & Fri & SL 1 & 14 & 28 & 3-Jul & Sat & SL 1 \\
\hline 4 & 7 & 12-Jun & Sat & SL 1, SL 18 & 15 & 29 & 4-Jul & Sun & SL 1 \\
\hline 4 & 8 & 13-Jun & Sun & SL 1 & 15 & 30 & 5-Jul & Mon & SL 1, SL 18 \\
\hline 5 & 9 & 14-Jun & Mon & SL 1 & 16 & 31 & 6-Jul & Tue & SL 1, SL 18 \\
\hline 5 & 10 & 15-Jun & Tue & SL 1, SL 18 & 16 & 32 & 7-Jul & Wed & SL 1 \\
\hline 6 & 11 & 16-Jun & Wed & SL 1, SL 18 & 17 & 33 & 8-Jul & Thur & SL 1 \\
\hline 6 & 12 & 17-Jun & Thur & SL 1 & 17 & 34 & 9-Jul & Fri & SL 1, SL 18 \\
\hline 7 & 13 & 18-Jun & Fri & SL 1 & 18 & 35 & 10-Jul & Sat & SL 1, SL 18 \\
\hline 7 & 14 & 19-Jun & Sat & SL 1, SL 18 & 18 & 36 & $11-J u l$ & Sun & SL 1 \\
\hline 8 & 15 & 20-Jun & Sun & SL 1 & 19 & 37 & 12-Jul & Mon & SL $1, \mathrm{SL} 18$ \\
\hline 8 & 16 & 21-Jun & Mon & SL 1, SL 18 & 19 & 38 & 13-Jul & Tue & SL 1 \\
\hline 9 & 17 & 22-Jun & Tue & SL 1 & 20 & 39 & 14-Jul & Wed & SL 1, SL 18 \\
\hline 9 & 18 & 23-Jun & Wed & SL 1, SL 18 & 20 & 40 & 15-Jul & Thur & SL 1 \\
\hline 10 & 19 & 24-Jun & Thur & SL 1 & 21 & 41 & 16-Jul & Fri & SL 1 \\
\hline 10 & 20 & 25-Jun & Fri & SL 1, SL 18 & 21 & 42 & 17-Jul & Sat & SL $1, \operatorname{SL} 18$ \\
\hline 11 & 21 & 26-Jun & Sat & SL 1, SL 18 & & & & & \\
\hline 11 & 22 & 27-Jun & Sun & SL 1 & & & & & \\
\hline
\end{tabular}

\subsection{Hydroacoustics}

We obtained fish passage data using fixed-location hydroacoustics and nearfield fish movement data using acoustic imaging.

\subsubsection{Fixed-Location Hydroacoustics}

The fixed-location hydroacoustic technique was employed to accomplish the Objectives 1-3 (see p. 1.2) of this study. This technique, conceived by Carlson et al. (1981) for single-beam acoustic systems, is described by Thorne and Johnson (1993). In addition to single-beam, split-beam technology is now an important element of fixed-location hydroacoustics. The split-beam technique is explained by MacLennan and Simmonds (1992). The methods used in 2004 were similar to those employed in the 2001 and 2002 hydroacoustic studies at The Dalles Dam (Moursund et al. 2002, Johnson et al. 2003).

The general approach was to deploy a combination of single-beam and split-beam transducers to sample fish, and apply the acoustic screen model to estimate fish passage rates and distributions. Split-beam transducers provided data to determine weighting factors, assess assumptions of the model, and determine the magnitude of any biases. Split-beam transducer deployments at each type of passage route were used to estimate the average backscattering cross section of fish for detectability modeling and the direction of fish travel through sampling volumes to assess the assumptions of the acoustic screen model. Single and split-beam transducers were deployed to 
sample fish passage at the spillway, sluiceway, and turbines. Transducer sampling volumes were positioned to minimize ambiguity in ultimate fish passage routes and the potential for multiple detections of the same fish.

\section{Hydroacoustic Systems}

Data collection involved five Precision Acoustic Systems (PAS) single-beam hydroacoustic systems. Split-beam data collection included four PAS split-beam systems. All systems operated at $420 \mathrm{kHz}$. The data collection systems consisted of either Harp-1B (Single-Beam) or Harp-SB (SplitBeam) Data Acquisition/Signal Processing Software installed on a personal computer controlling a PAS-103 Multi-Mode Scientific Sounder. The PAS-103 Sounders controlled transducers deployed in main turbine units, fish units, sluiceway entrances, and spill bays. A total of 44 transducers (28 single-beam and 16 split-beam) were deployed at the powerhouse, sluiceway, and spillway (Table 3.2). All systems used a voltage output threshold of $-56 \mathrm{~dB}$ re: $1 \mu$ pa at $1 \mathrm{~m}$.

Table 3.2. Sample Locations and Spatial Sampling Intensity at The Dalles Dam in 2004.

\begin{tabular}{|l|l|l|l|l|}
\hline Area & $\begin{array}{l}\text { Intensity } \\
\text { by Unit }\end{array}$ & $\begin{array}{l}\text { Intensity by } \\
\text { Intake }\end{array}$ & $\begin{array}{l}\text { Number of } \\
\text { Transducers }\end{array}$ & Sample Locations \\
\hline Fish Units & 2 of 2 & 1 of 2 & 2 & FU 1-2, 2-1 $1^{\text {(a) }}$ \\
\hline $\begin{array}{l}\text { Main Units } \\
1-22\end{array}$ & 18 of $22^{\text {(b) }}$ & 1 of 3 & 18 & $\begin{array}{l}\text { MU 1-3, 2-3, 5-1, 8-1, 9-3, 10-1, 11-1, } \\
12-3,13-2,14-3,15-2,16-1,17-2,18-1, \\
19-1,20-2,21-2,22-3\end{array}$ \\
\hline Sluiceway & 2 of 2 & 6 of 6 & 12 & $\begin{array}{l}\text { Sluice } 1-1,1-2,1-3, \\
18-1,18-2,18-3\end{array}$ \\
\hline Spillway $^{(\mathrm{c})}$ & 10 of 10 & $\mathrm{n} / \mathrm{a}$ & 12 & Bays $1,2,3,4,5 \mathrm{n}, 5 \mathrm{c}, 5 \mathrm{~s}, 6,7,8,9,10$ \\
\hline
\end{tabular}

(a) The transducer in FU 2-1 stopped working $2 \mathrm{~d}$ after the study started and was not replaced because adjacent units were being sampled.

(b) MU 3, 4, 6, and 7 were not sampled because they were off-line for maintenance.

(c) Spill Bays 1-6 were always open; Bays 7-10 were opened occasionally to pass water during high flows. There were three transducers in Bay 5 for a focused study of fish distribution.

\section{Transducer Locations and Orientations}

Single-beam transducers $\left(6^{\circ}\right)$ were installed at all turbine unit sampling locations, except for MU 2, which had a $6^{\circ}$ split-beam transducer (Figure 3.1). The intakes sampled at a given turbine unit and the horizontal placement of the transducers in that intake were randomly chosen. At all turbine intake sampling locations, with the exception of the fish units, divers installed transducers on the bottom of the second to the last trash rack at elevation $74 \mathrm{ft}$ and aimed the transducers downstream and upward toward the intake ceiling at a $23^{\circ}$ angle to the plane of the trash rack (Figure 3.2). At the main units, turbine intake transducer mounts were designed to fit between the vertical bars of the trash rack. With the exception of the fish units, this design allowed divers to secure the mount to the trash rack of each intake from the forebay. A diver took a transducer/mount/cable assembly to the bottom of the second to the last trash rack from the forebay bottom. The diver then installed the mount between two vertical bars of the trash rack at elevation $74 \mathrm{ft}$ and secured the mount to the trash rack with "J" bolts. 


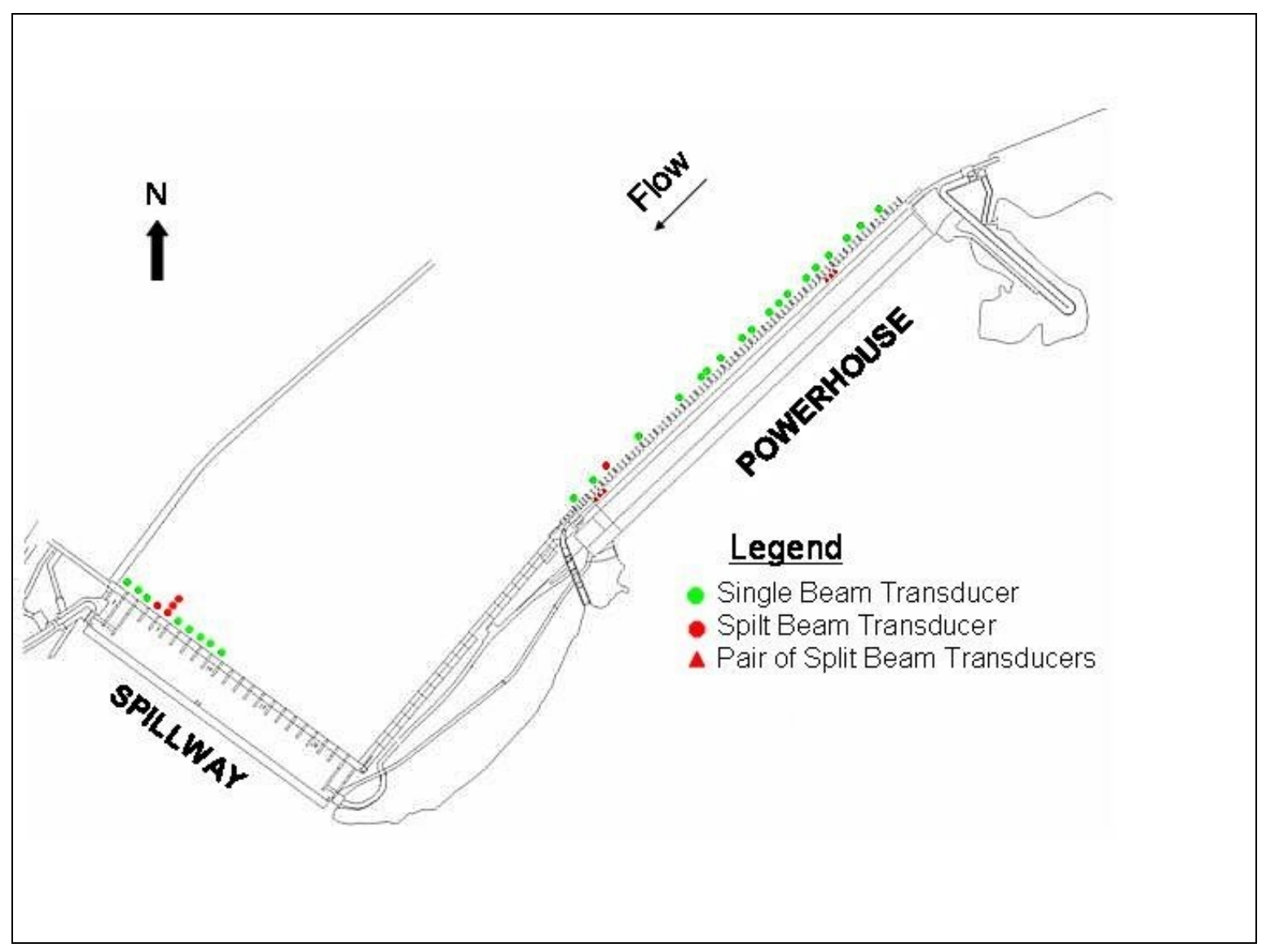

Figure 3.1. Plan View of The Dalles Dam Showing Transducer Locations.

Transducers in the fish units were installed on the top trash rack at elevation $135 \mathrm{ft}$, aimed downstream and downward at a $15^{\circ}$ angle to the plane of the trash rack (Figure 3.3). Penetration dives were required for transducer installation because the spacing of the vertical bars of the trash racks was not wide enough to allow the transducer and mount assembly to be mounted from the forebay. Divers took a transducer attached to a mount and telemetry cable to the inside of the top trash rack. A diver then bolted the mount assembly to a horizontal bar of the trash rack at elevation $135 \mathrm{ft}$, aiming the transducer downstream toward the intake floor. The transducer was affixed to the mount assembly such that it was at a $15^{\circ}$ angle to the plane of the trash rack once deployed. 
Hydroacoustic Evaluation of Juvenile Salmonid Passage at The Dalles Dam in 2004

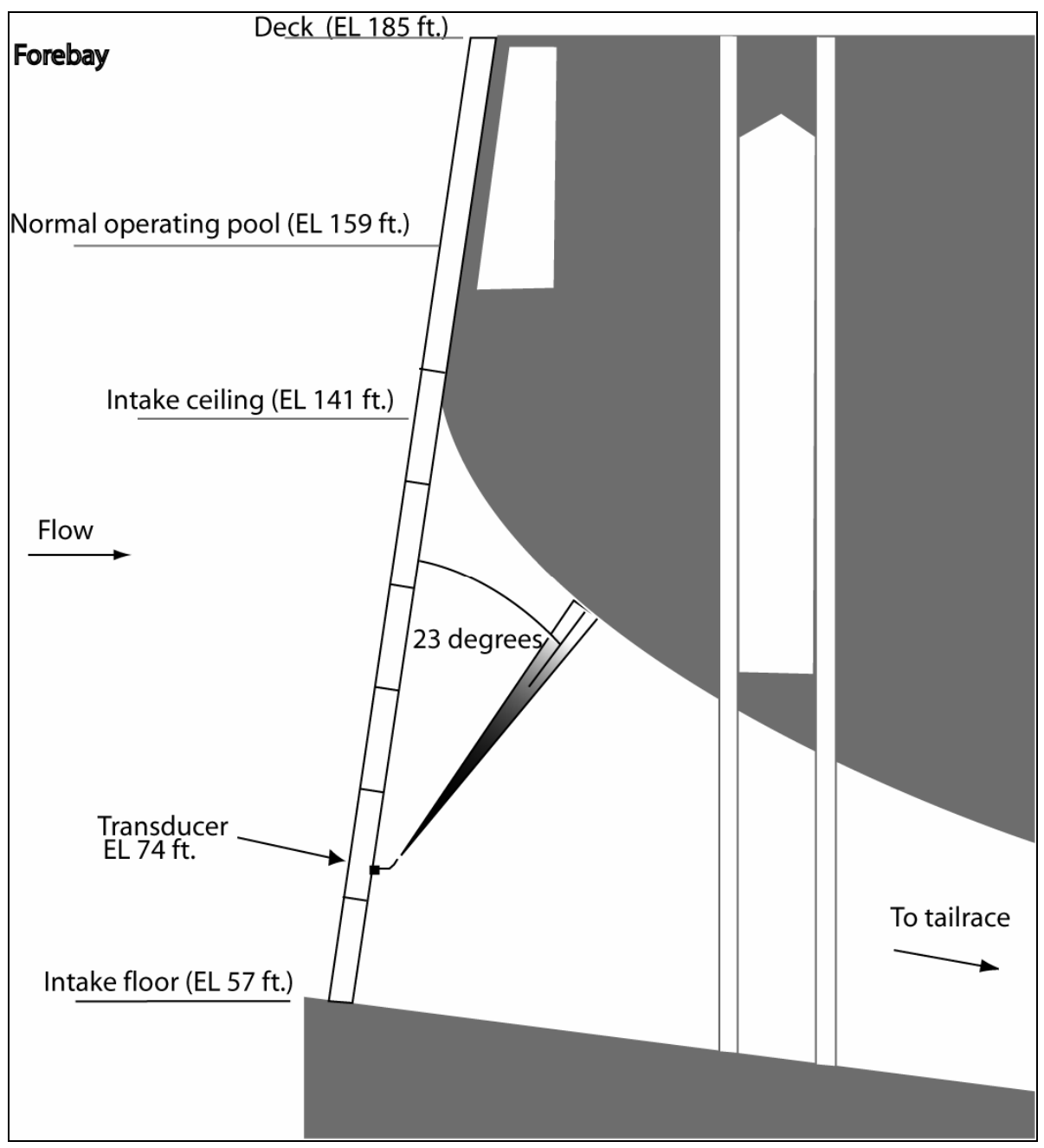

Figure 3.2. Cross-Sectional View of a Main Unit Transducer Deployment. 


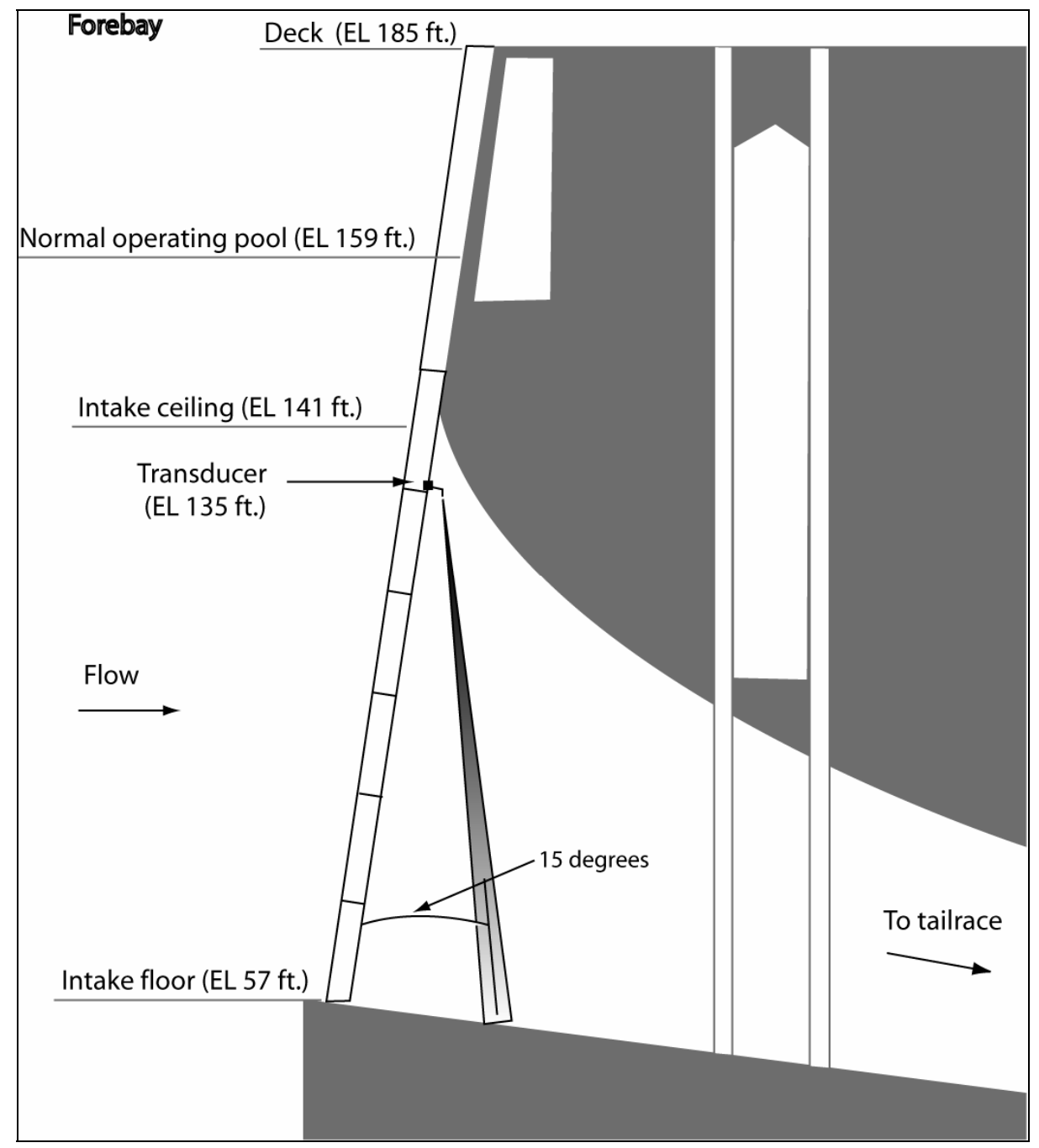

Figure 3.3. Cross-Sectional View of a Fish Unit Transducer Deployment.

Sluiceway transducers ( $6^{\circ}$ split-beam) were installed at each of the three sluice entrances of MU 1 and 18 (Table 3.2). Transducers were attached to mounts, which were then affixed to either steel Ibeams installed on the front of pier noses or on the "J" extensions of the occlusion plates of MU 1 at elevation $153 \mathrm{ft}$ (Figures 3.4 and 3.5). Each sluice entrance was monitored by a pair of transducers aimed horizontally and back at a $60^{\circ}$ angle to the plane of the sill across the sluiceway entrance (Figures 3.6 and 3.7). 


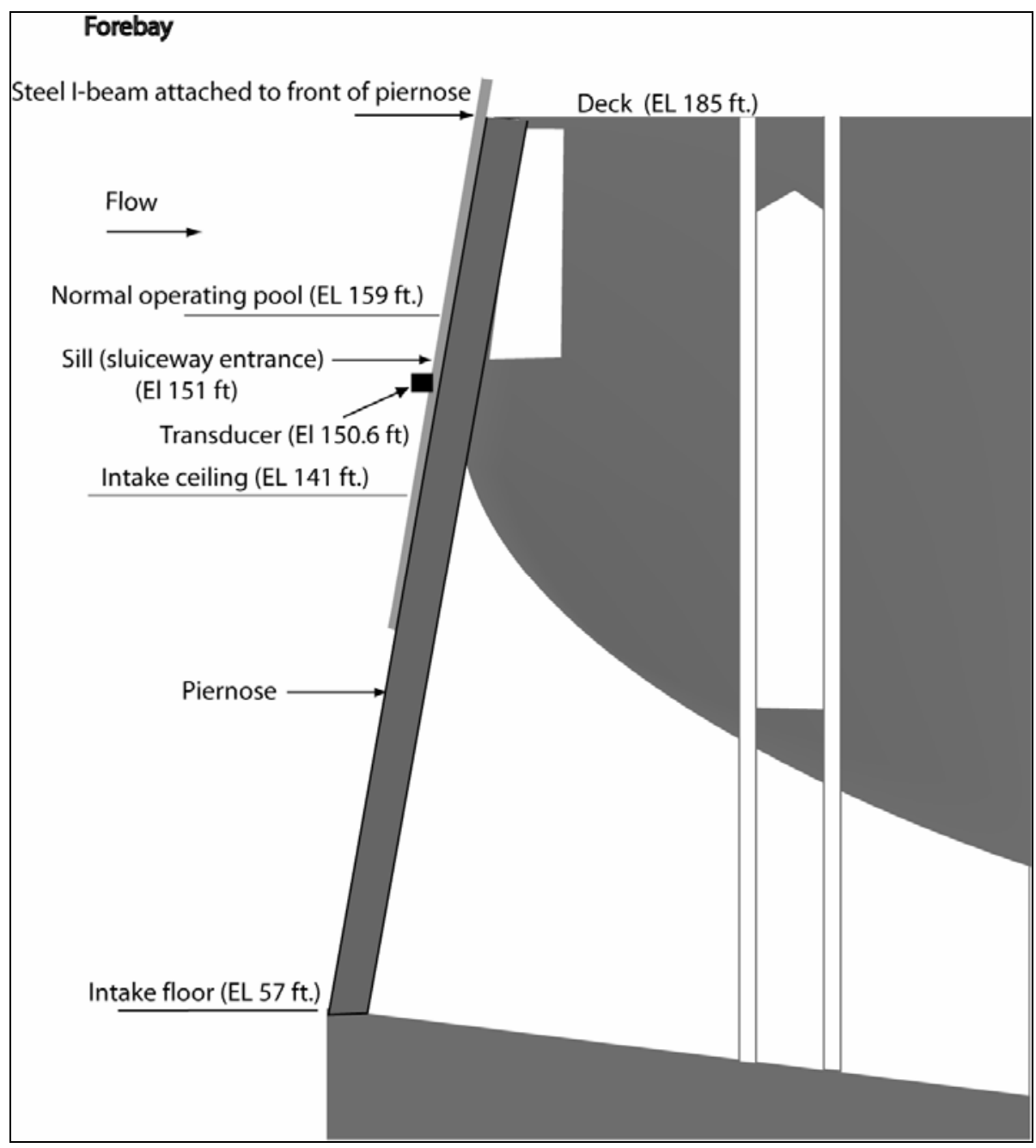

Figure 3.4. Deployment for a Side-Looking Sluiceway Transducer Mounted on a Steel I-Beam Attached to the Front of a Pier Nose.

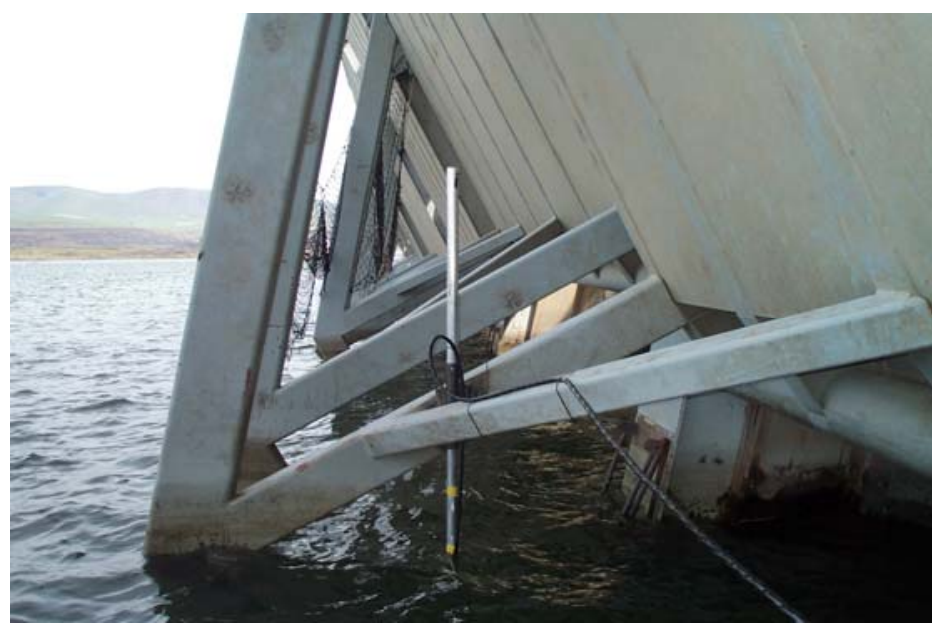

Figure 3.5. Deployment for a Side-Looking Sluiceway Transducer mounted on "J" Occlusion Extension (MU 1). 


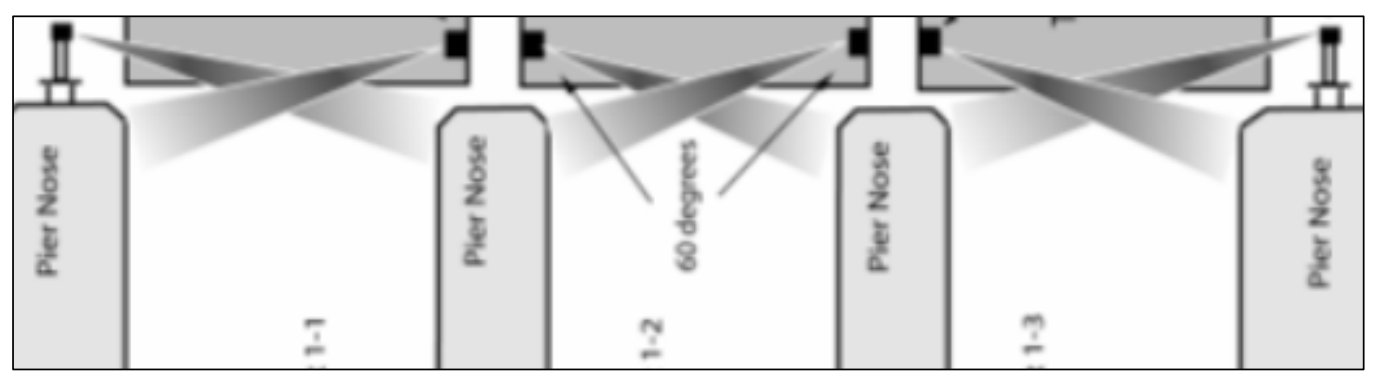

Figure 3.6. Top View of Transducer Deployment for SL 1. Shaded area to the right is J-Block structure. The forebay is on the right side of the figure.

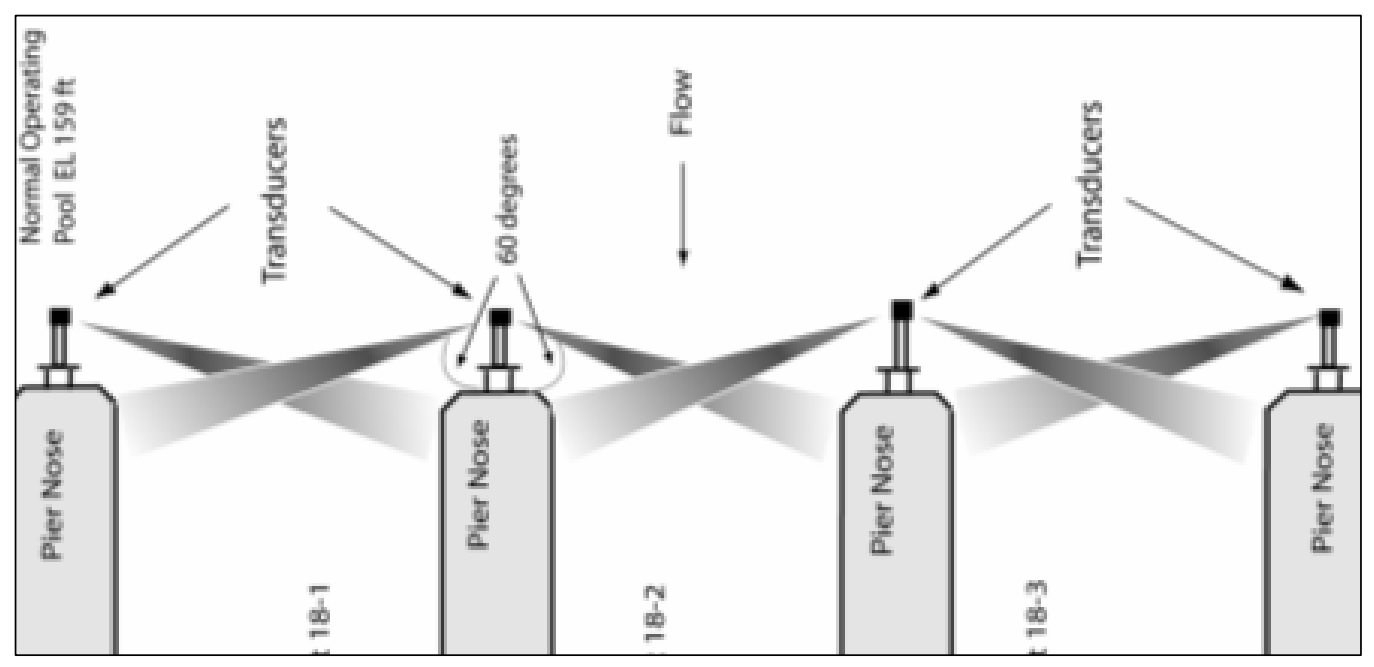

Figure 3.7. Top View of Transducer Deployment for SL 18. The forebay is on the right side of the figure.

The spillway transducers were installed in Bays 1-10, with $10^{\circ}$ single-beam transducers in all bays except Bays 4 and 5, which had $10^{\circ}$ split-beam transducers (Table 3.2). Three split-beam transducers were placed in Bay 5 to sample vertical and horizontal distribution data in a spill bay. Transducers were attached to pole mounts and deployed under deck plates. All transducers were placed about $6 \mathrm{ft}$ below the surface (elevation $152.5 \mathrm{ft}$ ) and aimed downward and downstream at an $8^{\circ}$ angle from vertical (Figure 3.8). Each transducer was randomly placed in either a north, middle, or south location of a given spill bay. 


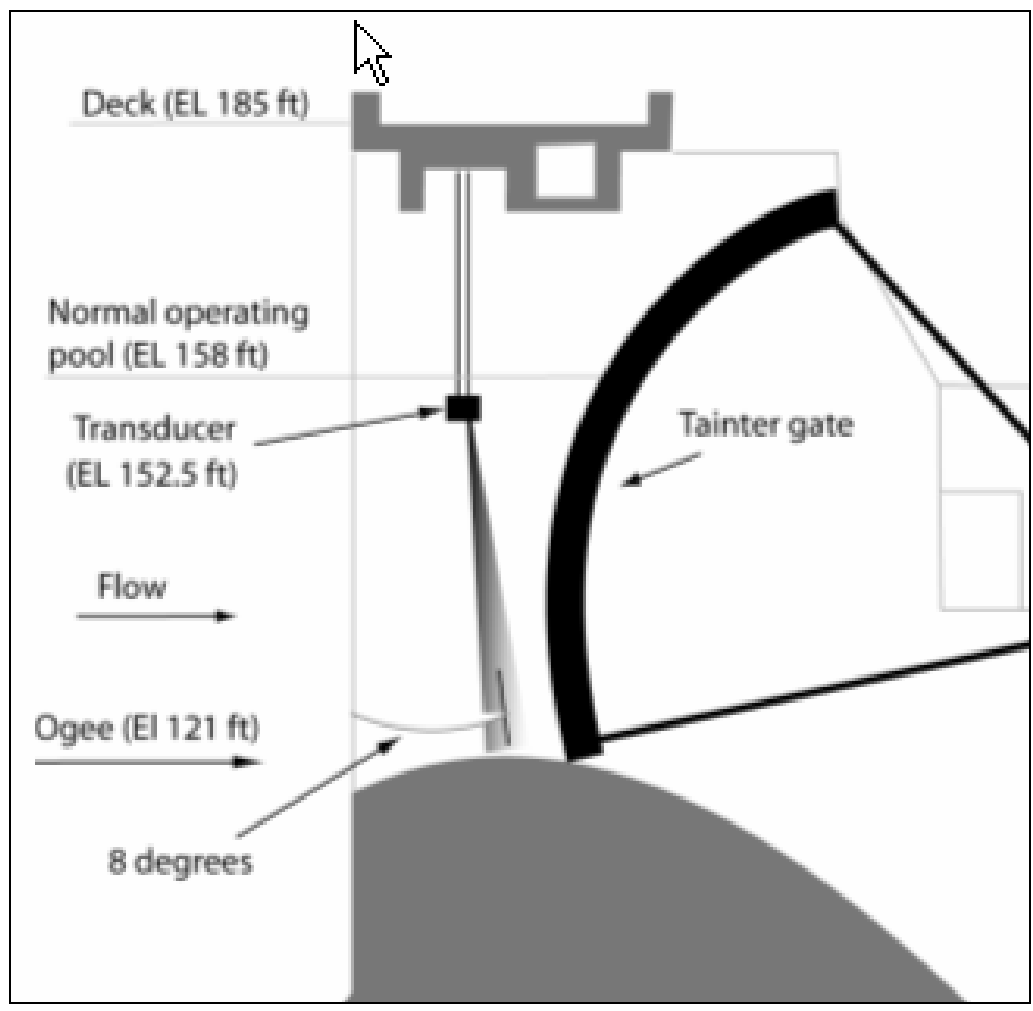

Figure 3.8. Cross-Sectional View of a Spill Bay Transducer Deployment.

\section{Sampling Design}

Echo sounder transmission rates were $15 \mathrm{pps}$ (pings per sec) at the turbine intakes, $30 \mathrm{pps}$ at the spillway, and 20 pps at the sluiceway. Systematic samples, i.e., same order among sampling locations each hour, were collected at 1-min intervals $24 \mathrm{~h} / \mathrm{d}$. Each location was sampled 6 to 10 times per hour depending on the number of transducers connected to the sounder.

\section{Data Processing and Reduction}

After the acoustic echo data were collected and archived, they were processed to extract fish tracks. At this stage in the analysis, we were careful to set the tracking parameters to include all fish at the expense of including spurious tracks. Next, to separate acceptable from unacceptable tracks, we filtered using fish tracks characteristics such as slope and pulse width. This data processing and reduction process was similar to that used by Johnson et al. (2003).

\section{Data Analysis}

The process to estimate passage rates from tracked fish is explained in detail in Appendix A. Briefly, each fish detection was weighted spatially to account for the sample width of the acoustic beam at the target's mid-range relative to the width of the passage route. The sum of these weighted fish was then extrapolated temporally by the hourly sampling fraction (60/total hourly sample time per location). The variances associated with each passage rate estimate were likely underestimates because between-intake variability in passage within a given turbine unit could not be accounted for because of sampling limitations. Ninety-five percent confidence intervals $(C I)$ were calculated as follows: 


$$
C I= \pm 1.96 * \sqrt{\text { Variance }}
$$

The passage rate data were used to estimate various performance metrics, including fish passage efficiency, spillway efficiency and effectiveness, sluiceway efficiency and effectiveness, and sluiceway passage. Equations for each estimator are contained in Appendix A.

\section{Statistical Analysis}

To statistically compare the West only and West+East sluiceway treatments, sluiceway efficiency and sluiceway passage were used as response variables in a 2-way (block and treatment) analysis of variance (ANOVA). For the purposes of this study, separate analyses for day and night periods (day defined as $0600-2000 \mathrm{~h}$ in spring and 0600-2100 $\mathrm{h}$ in summer) were performed for each metric. The sluiceway passage data and the sluice efficiency data were transformed using the natural logarithm or arcsin functions, respectively. Two-tailed statistical tests were employed because the main concern was whether the difference observed in the response variable between the two treatments was significant. See Appendix A for more details, including the ANOVA model.

\subsubsection{Acoustic Imaging}

To determine fish movements at the sluiceway, a Dual Frequency Identification Sonar (DIDSON) was deployed. The DIDSON bridges the gap between conventional scientific fisheries sonar, which can detect acoustic targets at long ranges but cannot record the shapes of targets, and optical systems, which can record images of fish but are limited at low light levels or when turbidity is high. The DIDSON has high resolution and fast frame rate enabling it to substitute for optical systems in turbid or dark water. This device was successfully applied at The Dalles Dam in previous research on predator distributions relative to the J-occlusion plates (Johnson et al. 2003). Figure 3.9 shows an example image of adult and juvenile salmonids observed using the DIDSON.

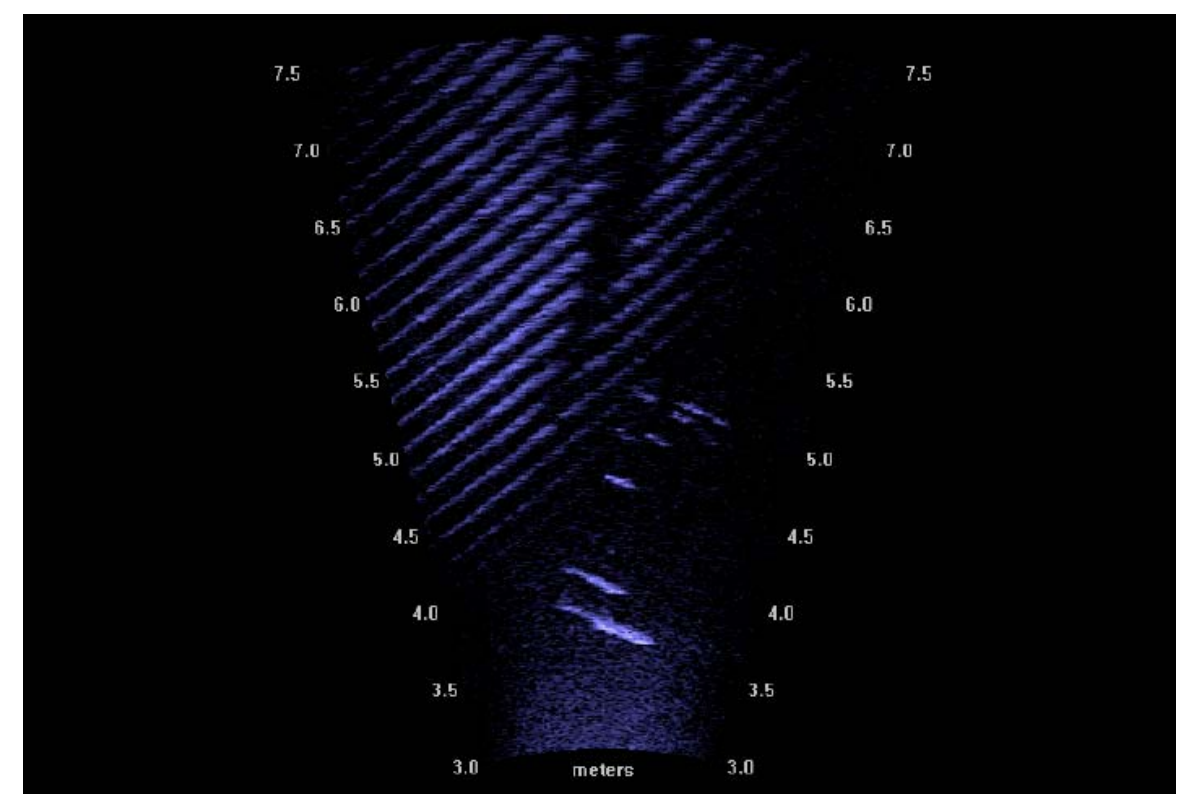

Figure 3.9. Screen from the DIDSON Display. The image shows two adult fish in foreground and smaller smolt-sized fish near the trashrack during 2002. 


\section{Sampling Locations and Schedule}

The DIDSON was used to sample fish movement at two locations: pier nose MU 1/2 for SL 1 and pier nose MU 18/19 for SL 18 (Table 3.3). The DIDSON was mounted to a pan and tilt rotator (Remote Ocean Systems PT 25) and positioned manually to follow fish in front of the sluiceway entrances at SL 1-3 and SL 18-3. The DIDSON was used in the high frequency mode and the frame rate was 6-7 frames/sec. The elevation at which the DIDSON was deployed varied depending on location. The maximum depth at which the trolley could be lowered was restricted due to the split beam transducer, which was deployed just below the DIDSON. For the majority of the study, the elevation at SL 1 was $\sim 155 \mathrm{ft}$ and at SL18 the elevation was $\sim 154 \mathrm{ft}$.

Table 3.3. DIDSON Sampling Schedule. A sampling day started at $0800 \mathrm{~h}$ and lasted for $24 \mathrm{~h}$.

\begin{tabular}{|c|c|c|c|}
\hline Date & DIDSON Location & Date & DIDSON Location \\
\hline May 5 & SL 1 & June 7 & SL 18 \\
\hline May 6 & SL 1 & June 8 & SL 18 and 1 \\
\hline May 7 & SL 1 & June 9 & SL 1 \\
\hline May 11 & SL 18 & June 10 & SL 1 \\
\hline May 12 & SL 18 and 1 & June 28 & SL 1 \\
\hline May 13 & SL 1 & June 29 & SL 1 \\
\hline May 14 & SL 1 & June 30 & SL 1 and 18 \\
\hline May 25 & SL 1 & July 1 & SL 18 \\
\hline May 26 & SL 1 & July 9 & SL 18 \\
\hline May 27 & SL 1 and 18 & July 10 & SL 18 \\
\hline May 28 & SL 18 & July 13 & SL 1 \\
\hline June 2 & SL 18 & July 14 & SL 1 \\
\hline June 3 & SL 18 & July 15 & SL 1 \\
\hline
\end{tabular}

\section{Deployment and Aiming Angles}

We mounted the DIDSON to an aluminum trolley and lowered it down a steel 4-inch wide Ibeam. This beam was welded to the J-plate guide frame at the pier nose between MU 1 and 2. At the pier nose between MU 18 and 19, an I-beam was secured with anchor bolts to the concrete pier. The trolley was raised and lowered using an electric winch and davit (Figure 3.10). A pan and tilt rotator was fastened to the trolley and the DIDSON was then fastened to the rotator (Figure 3.11). This instrument allowed us to position the DIDSON array with relatively high accuracy ( $\pm 1^{\circ}$ azimuth) on the pan and tilt axes. The aiming angles (in degrees) from the rotator were also incorporated into the DIDSON program using a serial Data Acquisition (DAQ) Module. This allowed the feedback from the rotator's pan and tilt angles to be to be associated with each DIDSON file. 


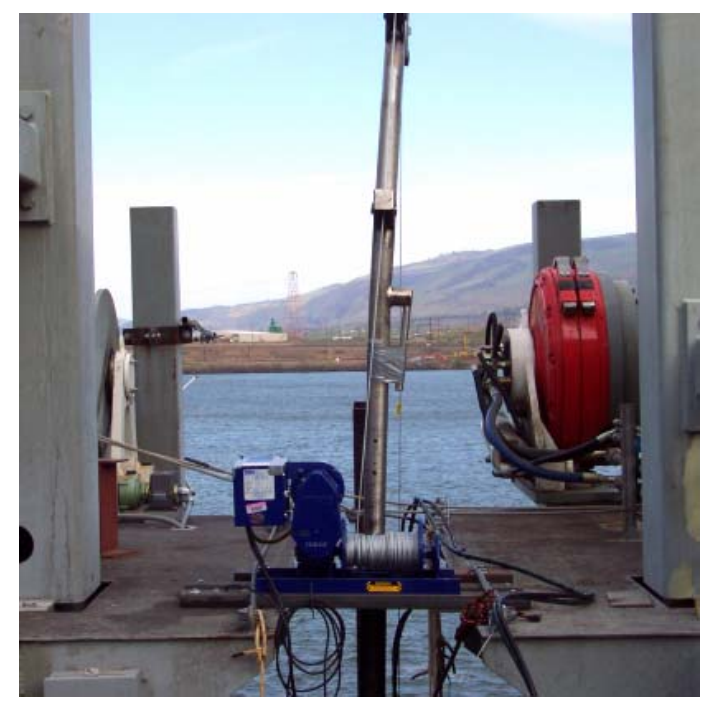

Figure 3.10. Electric Hoist and Davit System Used to Deploy the DIDSON.

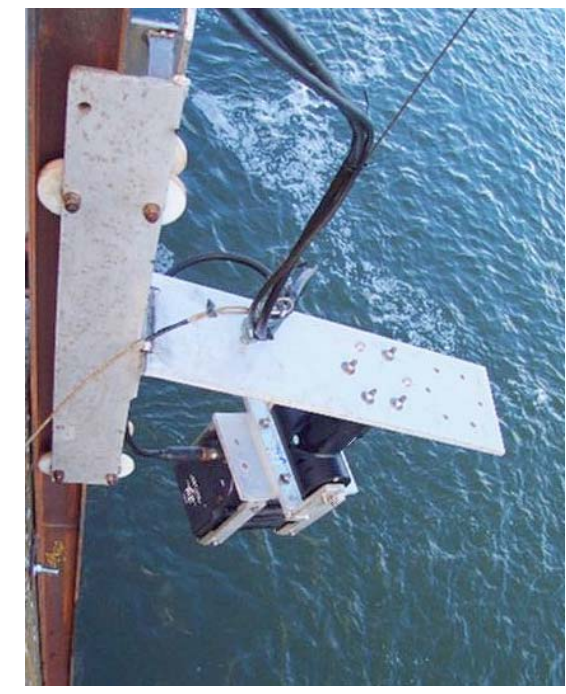

Figure 3.11. DIDSON Mounted to Pan and Tilt Rotator and Trolley.

\section{Sampling Zones}

Data collection consisted of sampling fish in six $30^{\circ}$ pie-shaped horizontal zones in the surface layer along the face of the dam at SL 1 and SL 18 (Figure 3.12). The zones were sampled randomly without replacement. A randomized table was used to determine the six zones sampled each hour (10 min each). Operators positioned the DIDSON using the rotator controller to a predetermined "pan" position for each zone. The tilt angle was held at a near horizontal angle at the start of each zone. When fish were observed entering the sonar array, the tracker would note the time on the data sheet and trigger a queue that was integrated into the data file, then proceed to track the fish using the pan and tilt function until the fish was lost from view. 


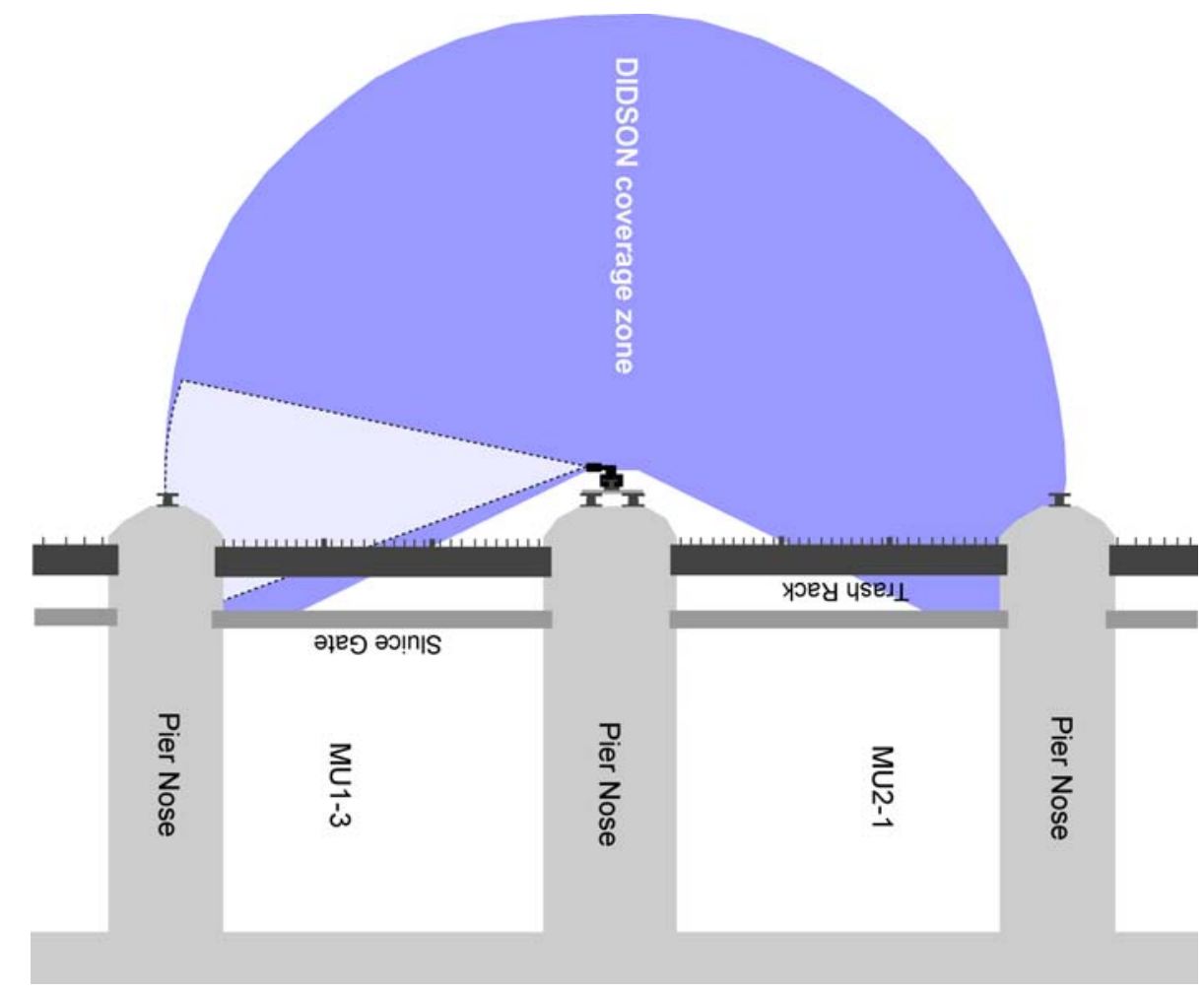

Figure 3.12. Plan View Showing the DIDSON Sampling Location at SL 1. The light blue shading represents the approximate coverage area of one of the six sampling zones.

\section{Data Processing}

A Visual Basic program was created to extract spatial information from tracks of individuals and groups of fish in binary files of the DIDSON acoustic camera. The program interactively identified fish tracks by boxing around fish in each frame display using a mouse pointer. The relative coordinates of the box's opposite corners were recorded in ASCII data files with the binary track file name, frame number, date, time, pan angle, tilt angle, roll angle, number of fish in box and a unique track identification number. The roll angle was not an angle per se but a variable used to indicate a switch set when the observer followed fish as the DIDSON was rotated. From this step, the primary data for each track were time and three-dimensional position relative to the dam. Positional data were also expressed in Oregon State Plane North (OSPN) coordinates (NAD 27). The tracks were then analyzed for directionality (see Appendix B), displayed and animated using custom software, and subjected to a Markov Chain analysis.

Several steps were made after obtaining the tracked fish files and prior to Markov chain analysis. These included conversion to fixed coordinate systems, fish track visualization, separation into season and day-night datasets, and selection of the volumes to analyze. The process of aligning the relative tracked fish data to fixed coordinates consisted of applying pan and tilt angle corrections, DIDSON elevation corrections, and rotations and translations to two different coordinate systems. For the Markov chain analysis, the coordinate system we applied was relative to the center of the main piernose where the DIDSON was located at the sluiceway sill elevation of $151 \mathrm{ft}$. At MU 1 coordinates were relative to a reference point "TDP1" with easting 1839844.0 , northing 711330.743 (OSPN feet) (near the main piernose at MU 1-1). The DIDSON $x-y$-z-origin was measured relative 
to this point $84.25 \mathrm{ft}$ along deck ( $43.8^{\circ}$ north of east), $7.83 \mathrm{ft}$ out to the DIDSON camera at deck level and downward at a slope of 1:5 to its elevation of approximately $155 \mathrm{ft}$ although this elevation varied over the course of the study due to redeployments. At Unit 18 coordinates were relative to a reference point "TDP10" with easting 1841000.16, northing 712440.59 (OSPN feet) (near the piernose between MU 18-2 and 18-3). At Unit 18 the DIDSON $x$ - $y$-z-origin was measured relative this point $26.75 \mathrm{ft}$ along deck ( $43.8^{\circ}$ north of east), $6.67 \mathrm{ft}$ out to the DIDSON camera at deck level and downward at a slope of 1:5 to its elevation of approximately $154 \mathrm{ft}$.

In relative coordinates, the $\mathrm{x}$-axis was parallel to the powerhouse at an angle of $43.8^{\circ}$ towards north from the easting parallel. The $y$-axis was perpendicular to the powerhouse at the center of the main piernose between MU 1 and MU 2 or between MU 18 and MU 19. The origin was set at the piernose face at elevation $151 \mathrm{ft}$, the bottom of the sluiceway. The DIDSON acoustic camera was located at several elevations based on river water level and deployment. DIDSON elevations required for adjusting the tracked fish coordinates were part of a computer program that computed both state plane and dam relative tracked fish coordinates. Output files were named "*.SPL" for Oregon State Plane coordinates, “*.PCA” for relative coordinates, “*.TEC” for Amtec Engineering's Tecplot software visualization in relative coordinates.

Using the two relative to DIDSON camera positions of the fish track box, (X1, Y1) and (X2, Y2), their ranges $(\mathrm{R} 1, \mathrm{R} 2)$ and the tilt angle $\theta$, a single tracked fish position corresponding to the track box (and relative to the pointing angle of DIDSON camera) was computed as:

$$
\left(\frac{X_{1}+X_{2}}{2}, \frac{Y_{1} \cos (\theta)+Y_{2} \cos (\theta)}{2}, \frac{R_{1} \sin (\theta)+R_{2} \sin (\theta)}{2}\right) .
$$

This position was corrected by applying rotation and translation into positions in the two coordinate systems described above.

\section{Markov Chain Analysis}

The methods used to analyze fish movement were similar to those used in recent years (Johnson et al. 2004) at The Dalles Dam except that they are applied to the DIDSON data instead of an active tracking split-beam sonar. We used an absorbing Markov chain (Kemeny and Snell 1960) to capture fish movement to a particular location where we considered fish were entrained into the sluiceway. A Markov chain can model continuous movement in a continuous volume when discrete time steps are chosen and volumetric cells of a sample volume are delineated over which transition movement probabilities can be calculated. Our Markov chain model allowed us to estimate fish movement probabilities from a given cell within the sample volume to each absorbing cell.

The sample volume coordinate system (Figure 3.13) was defined as follows:

- $\mathrm{x}$-dimension was parallel to the dam with northeast movement in the positive $\mathrm{x}$-dimension and southwest movement in the negative $\mathrm{x}$-dimension;

- y-dimension was perpendicular to the dam with movement toward the dam in the negative ydimension and movement away from the dam in the positive y-dimension;

- z-dimension was vertically in the water column with movement upward in the positive zdimension and movement downward in the negative z-dimension. 


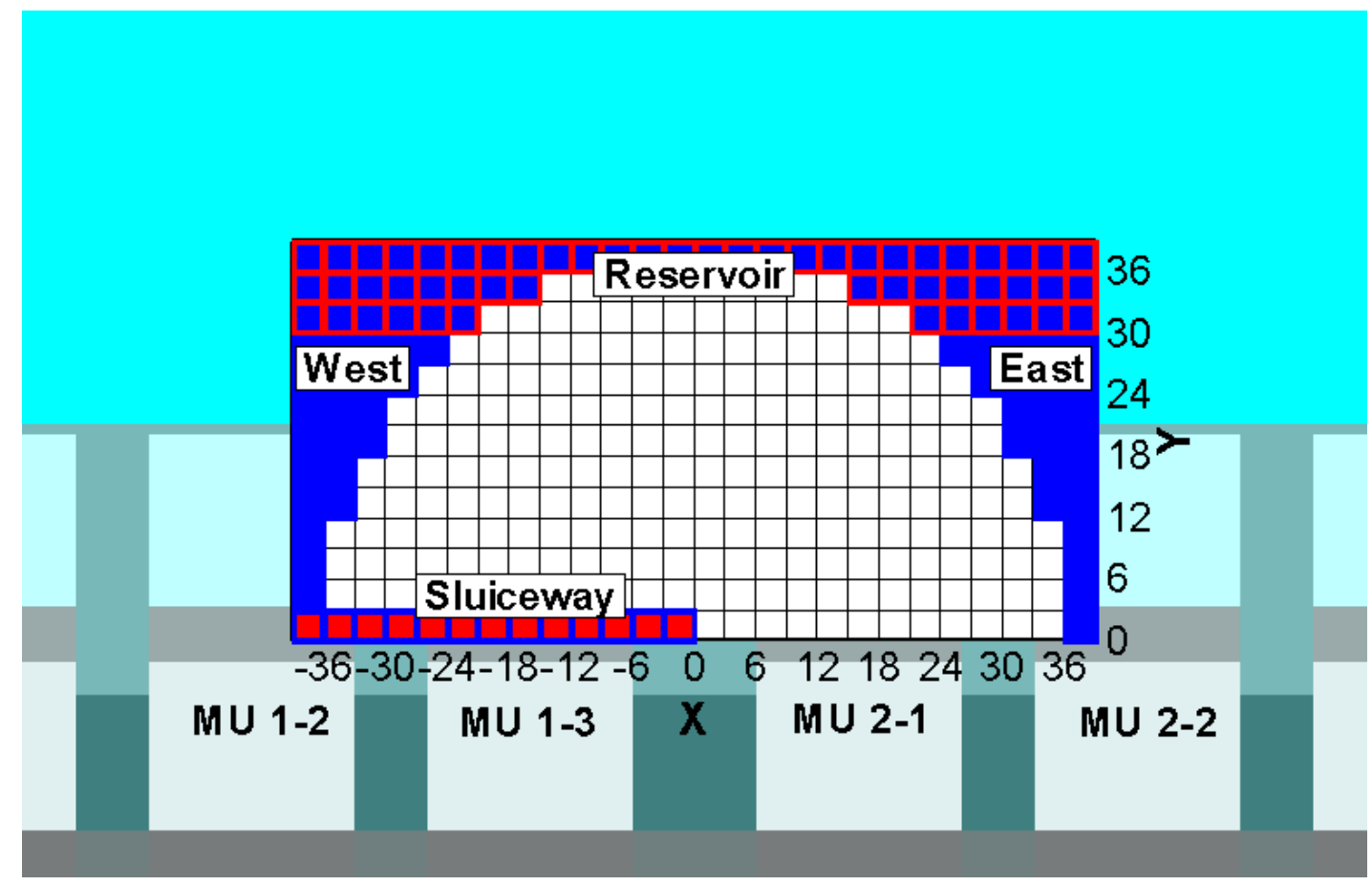

Figure 3.13. Fates where fish movements were absorbed at edges of the sample volume are as follows: Sluiceway, East, West, and Reservoir. Sluiceway entrances are located at MU 1-1, 1-2 and 1-3. A similar volume was made at Unit 18. Axes shown are in feet.

The DIDSON sample volume was semispherical. However, a rectangular volume was applied to apply the Markov chain analysis (Figure 3.13) that encompassed the DIDSON sample volume. The rectangular volume was $78 \mathrm{ft}(23.77 \mathrm{~m})$ across (along the dam), extended $39 \mathrm{ft}(11.89 \mathrm{~m})$ into the reservoir from the dam, and was $30 \mathrm{ft}(9.144 \mathrm{~m})$ deep from the surface. The sample volume was chosen to encompass a sufficient number of tracked fish to estimate movement. Fish movement in the water volume was randomly sampled by randomly moving between the six zones (evident in fish tracks of Figure 3.12) every ten minutes. If a fish was not detected within two minutes the pointing angle of the DIDSON camera within a zone was randomly repositioned. For the Markov chain analysis, the sample volume was partitioned into cells. The three-dimensional sample volume was modified to effectively form a two-dimensional sample volume by allowing the z-dimension of each cell to extend from the surface to $\mathrm{z}=-30 \mathrm{ft}$. The $\mathrm{x}$ - and $\mathrm{y}$-dimensions of cells were, $3.0 \mathrm{ft}(0.9144 \mathrm{~m})$ on a side. We formed states (Kemeny and Snell 1960) for the Markov chain that corresponded to the location of each volumetric cell (Figure 3.13). The sample volume was 26 cells wide in the $\mathrm{x}$ dimension, 13 cells out from the dam in the y-dimension, and 1 cell deep in the z-dimension (348 total cells and states, including absorption states).

Markov absorbing states (Kemeny and Snell 1960), called "Fates" here, were assigned on edges of the volume, except for the part of the Powerhouse where there was no sluiceway and hence no possibility of passage through the boundary. In addition, movement was not allowed through the surface or bottom. Fates were calculated as probabilities of absorption into cells at a particular portion of the sample volume as follows: Sluiceway, East (true northeast), West (true southwest), and Reservoir (Figure 3.13). Finally, when no movement to a boundary was observed, the fate was called Stagnation. Movement fates to the faces of the sample volume are simply probabilities for movements 
within the sample volume. In summary, the Markov model included absorption at the faces corresponding to one of four movement fates: Sluiceway, East, West, and Reservoir. Of these, the Sluiceway fate was used to characterize movement into sluiceways at MU 1-3 and MU 18-3 for this study. Out of the 348 total cells there were 52 Reservoir, 22 West, 23 East and 12 Sluiceway absorbing cells. There were 238 non-absorbing cells through which fish could move in the analysis. The distinction between West, Reservoir and East was made using a line at approximately $45^{\circ}$ from the origin at the powerhouse. The absorbing cells farther away than 1 cell from the non-absorbing cells are not required in a Markov chain analysis but were left for pragmatic reasons in the computation.

To determine fate probabilities, we applied a Markov chain analysis (Taylor and Karlin 1998), which described smolt movement as a stochastic process. A stochastic model does not imply that the fish movements are a random process of to and fro motions. Where a deterministic model describes movements as a function of covariates such as flow variables that are believed to govern fish behaviors, the movements are certain and without deviation. Instead, the Markov model describes the fish movements as a function of empirically observed transition probabilities. Taylor and Karlin (1998) noted that a Markov process $\{\mathrm{Xt}\}$ is a stochastic process with the property that, given a value $\mathrm{Xt}$, the values of $\mathrm{Xs}$, for $\mathrm{s}>\mathrm{t}$ are not influenced by the values of $\mathrm{Xu}$ for $\mathrm{u}<\mathrm{t}$. They also pointed out that transition probabilities are functions not only of the initial and final states, but also of the time of transition as well. When the one-step transition probabilities are independent of the time variable, then the Markov chain has stationary probabilities (Karlin 1968). The time of transition was set at $0.5 \mathrm{~s}$ and is constrained in our application by the nature of the data, specifically the size of the cells in the sample volume and the frame interval. That is, we chose a transition time small enough to characterize a fish track and (for efficiency in subsequent data manipulations) larger than the frame interval so that the probability of remaining in a cell was not large. The choice of volumetric cell size ( $3 \mathrm{ft}$ on $\mathrm{x}$ - and $\mathrm{y}$-sides) was based on having as many cells as possible with fish movement data given the number of samples and the velocity of fish movements.

Several assumptions were made and verified regarding connectivity in the sample volume for the Markov model. 1) There were no absorbing non-boundary cells. That is, no interior cell's probability was equal one. 2) Exterior cells' probabilities were set to one as described above. 3) No interior connectivity was forced but relied upon empirical measurements. 4) Where no movement observation from a cell was measured using the DIDSON camera, then the closest movement was interpolated to that cell using inverse distance squared weights.

A C-language program was used to construct a transition matrix and apply the Markov chain analysis, The Markov transition matrix was a square matrix the size of $\mathrm{k} \mathrm{x} \mathrm{k}$, where $\mathrm{k}$ was the number of distinct cells being modeled $(\mathrm{k}=348)$. The $\mathrm{ij}^{\text {th }}$ element in the ith row of the $\mathrm{j}^{\text {th }}$ column of the transition matrix was the estimated probability $\left(\mathrm{p}_{\mathrm{ij}}\right)$ of moving from cell $\mathrm{i}$ to cell $\mathrm{j}$ in the next time step. These probabilities were estimated by

$$
\hat{p}_{i j}=\frac{n_{i j}}{n_{i}}
$$

where,

$\mathrm{n}_{\mathrm{i}}=$ number of observations of smolts in the ith cell;

$\mathrm{n}_{\mathrm{ij}}=$ number of observations where a smolt in cell i moved to cell $\mathrm{j}$ in the next time step. 
The transition probabilities for cells $(3 \mathrm{ft} \times 3 \mathrm{ft})$ that bordered the edges of the sample volume (e.g., Sluiceway) were set to unity to absorb any movement that reached our defined fates. The transition matrix $\mathrm{T}$ was constructed using a time step of $0.5 \mathrm{~s}$, using average position (i.e., $\bar{x}, \bar{y}, \bar{z}$ ) during each 0.5 -s interval a fish was tracked. This process required that a fish be tracked for at least $1.0 \mathrm{~s}$ before the transition matrix was amended to obtain location $\mathrm{i}$ from the first interval and location $\mathrm{j}$ from the next, and so on.

After the transition matrix was formed, it was examined to find cells that were not sampled by the DIDSON acoustic camera. In these instances of no observation, nearby cells in Cartesian space with movement data were found and the movement patterns through those cells were interpolated to the cell with no observations using inverse distance squared weights. We limited the search radius to three cells away in order to use local data for interpolation. There were 38 and 42 cells that required this interpolation in spring at MU 1 and MU 18 respectively. Fewer cells were interpolated in summer: 24 cells at MU 1 and 20 cells at MU 18. Most of the interpolated cells were located near the main piernose on which the DIDSON was deployed. Presumably the lack of data was due to the start range $(0.75$ to $2.08 \mathrm{~m})$ and the more limited sampling volume at short ranges.

The transition matrix $\mathrm{T}$ for one time step was used to estimate the transition probabilities for two or more time steps as $T^{t}$ where $\mathrm{t}=$ the number of time steps. Matrix $T^{t}$ is the transition matrix for $\mathrm{t}$ time steps and the transition probabilities $p_{i j}{ }^{(t)}$ express the probability of moving from cell $\mathrm{i}$ to cell $\mathrm{j}$ in $t$ time steps. The size of $t$ was sufficiently large so that the tracked fish revealed an absorption state or became stagnant. The t-step transition probabilities to absorbing cells were visualized using Amtec Engineering's Tecplot software by contouring the sums of each state's (each representing an $\mathrm{x}, \mathrm{y}, \mathrm{z}$ cell) probabilities over the absorbing surfaces previously described.

\subsection{Hydraulics}

We obtained hydraulic data for this study from a computational fluid dynamics (CFD) model and acoustic Doppler current profiler measurements. In addition, hydraulic calculations for the sluiceway (presented in Table 2.1) were provided by the CENWP-Hydraulics Branch.

\subsubsection{Computational Fluid Dynamics Model}

A CFD model of The Dalles Dam forebay was used to simulate the hydrodynamics for various operational scenarios. The model runs were integrated with biological studies of the effect of sluiceway operations on the passage of juvenile salmonids. The computational mesh used for these simulations was created for the CENWP by ENSR (Redmond, WA) and PNNL (Richland, WA). For this study, the mesh was rotated and translated onto the State Plane feet, Oregon North geographic coordinate system. The TDA forebay CFD model included three intakes for each of the turbine units, individual spill bays, sluiceway inflows, and the station service flows. The model was composed of 803,000 fluid cells and a total of 1,090,821 cells. All simulations used STAR-CD, a commercial CFD solver. A given model run took about 3.5 hours to run on a 2.2-GHz dual processor Linux desktop with 4 GB of memory.

The CFD model was applied to eight scenarios representing spring and summer 2004 flows with and without SL 18 operating during two peak migration periods in each season (Table 3.4). We selected the time periods, obtained mean total discharges for the spillway and turbines, and then made 
a spreadsheet and allocated the discharges by location according to the patterns from the dam operations analysis. The following factors went into our decision-making for the CFD boundary conditions: 1) performed separate analyses for spring and summer, 2) collected DIDSON samples (see schedule in Table 3.3), 3) separated conditions for the West and West+East sluice operations, 4) desired as consistent as possible turbine operations, 5) times when the outmigration was at or near a peak, 6) limited the number of runs because of resource concerns.

Table 3.4. Scenarios for CFD Modeling. Forebay elevation is in feet and discharge (Q) is in cfs.

\begin{tabular}{|c|c|c|c|c|c|c|c|}
\hline Scenario Id. & Focus Dates & Treatment & Fbay Elev. & Sluice Q & Turbine Q & Spill Q & Total Q \\
\hline AW & May 11-13 & West only & 158.5 & 3,191 & 130,509 & 87,400 & 221,100 \\
\hline AWE & May 11-13 & West+East & 158.5 & 4,491 & 129,209 & 87,400 & 221,100 \\
\hline BW & May 25-27 & West only & 158.7 & 3,294 & 140,173 & 93,433 & 236,900 \\
\hline BWE & May 25-27 & West+East & 158.7 & 4,570 & 138,897 & 93,433 & 236,900 \\
\hline CW & Jun 7-9 & West only & 158.7 & 3,294 & 141,840 & 94,800 & 239,934 \\
\hline CWE & Jun 7-9 & West+East & 158.7 & 4,570 & 140,563 & 94,800 & 239,933 \\
\hline DW & Jun 28-30 & West only & 158.5 & 2,291 & 110,609 & 72,267 & 185,167 \\
\hline DWE & Jun 28-30 & West+East & 158.5 & 4,491 & 108,409 & 72,267 & 185,167 \\
\hline
\end{tabular}

\subsubsection{Acoustic Doppler Current Profilers}

\section{Powerhouse ADCP}

An acoustic Doppler current profiler (ADCP) was used to measure current velocity components near the sluiceway entrances at SL 1 and SL 18 at The Dalles Dam from May 24 to July 17, 2004. Our purpose was to use ADCP velocity measurements to investigate the temporal stability of flow near the DIDSON sampling volumes at the sluiceway. The RD Instruments Workhorse ADCP operated at $600 \mathrm{kHz}$, and its special construction included four squinted beams at 6 deg from the boresite (pointing direction of the unit).

The ADCP was located on a trolley and I-beam rail at the downstream pier noses at FU 2/MU 1 and MU 17/18 (Figure 3.14). At SL 1, the location of the outside of the I-beam rail was described as from The Dalles Position (TDP)-1, 21 inches west along power house and 61 inches into the forebay, plus a 22 -inch offset, equals 83 inches at deck elevation from TDP1 toward the reservoir. At SL 18, the ADCP was located from survey marker on pier 18-2, 650 inches west along powerhouse and 57 inches into the forebay, plus a 22 -inch offset equals 79 inches at deck elevation from the survey mark toward the reservoir. At both locations, the ADCP was $1 \mathrm{ft}$ out and $1 \mathrm{ft}$ upstream from the edge of the I-beam rail and angled $33.4^{\circ}$ out from the dam pointing upstream.

The ADCP was oriented so that Beam 1 was positioned near the surface, pointing slightly downward. The elevation and tilt of the ADCP varied slightly during the survey period. The average elevation and tilt were $155 \mathrm{ft}$ and 15 degrees downward from horizontal. Thus Beam 1 was oriented 
approximately 9 degrees downward from horizontal and 33 degrees outward into the reservoir from the dam's face.

The ADCP collected single ping ensembles. The time per ping was $0.2 \mathrm{~s}$ and the pulse length was $0.49 \mathrm{~m}$. There were $1280.5-\mathrm{m}$ collection bins for each ping. Fifty of the 128 bins, ranges 1.63 to $26.63 \mathrm{~m}$, were examined. This was approximately the horizontal extent of each sluiceway, although the ADCP was pointed slightly outward and downward. A three-beam solution of velocities was not attempted due to the heterogeneity in velocities over short distances in the sampling volume. Therefore, only the surface-most Beam 1 was analyzed. Average velocities along Beam 1 were computed for $1500 \mathrm{~s}$ in $0.5-\mathrm{m}$ bins. A total of 82 ADCP data files were processed with RDI's BBList software.

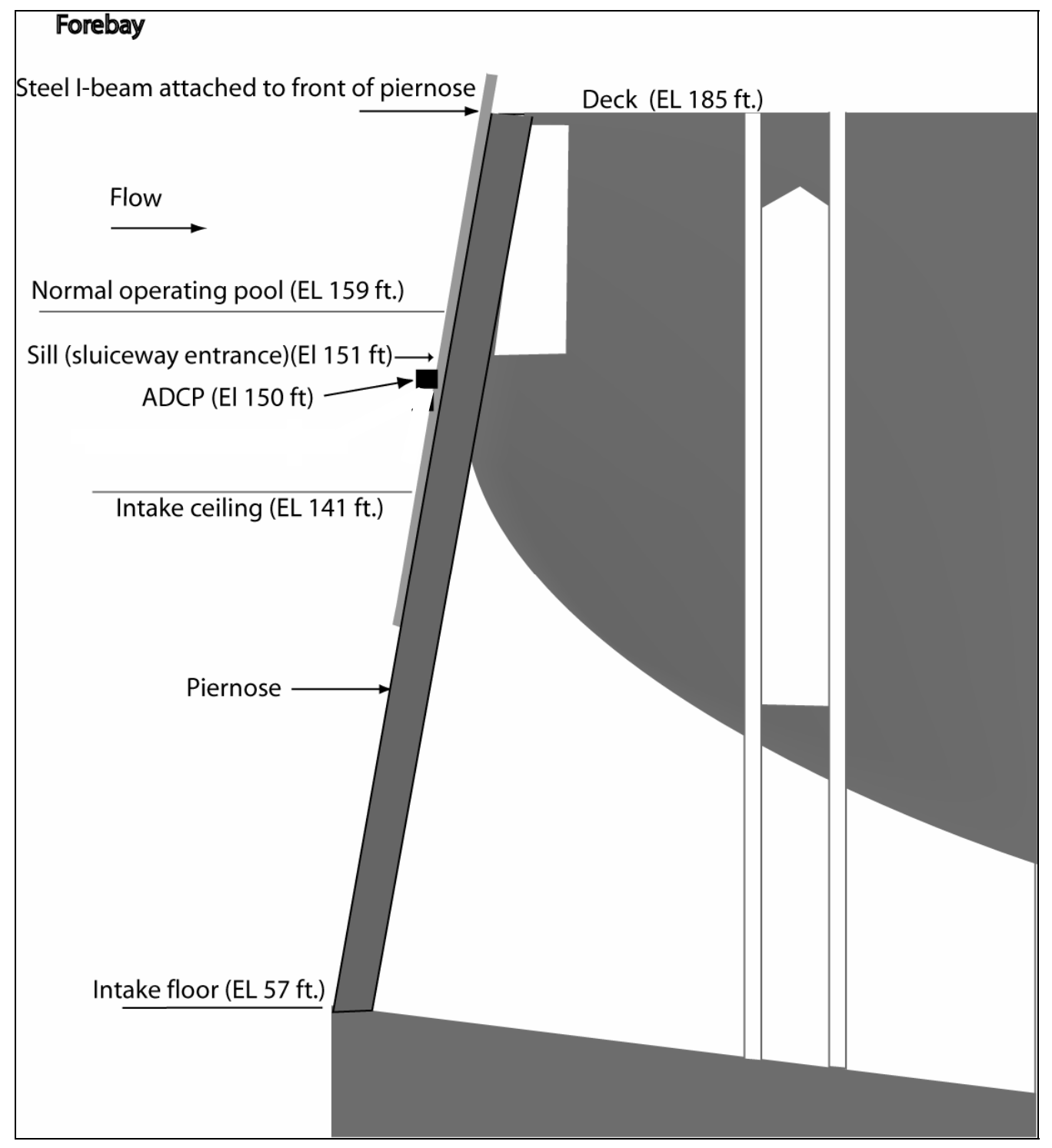

Figure 3.14. Cross-Sectional View of a Powerhouse ADCP Deployment. 


\section{Spillway ADCP}

We collected water velocity data upstream of Spill Bays 3 and 5 at The Dalles Dam between August 24 and September 1, 2004. Two different types of RD Instruments ADCPs were deployed during the spillway sampling. One ADCP (Figure 3.15) operated at $600 \mathrm{kHz}$ and was capable of collecting data at distances out to $50 \mathrm{~m}$ beyond the ADCP. This unit was deployed on a single-axis rotator and collected data at various angles from almost horizontally into the forebay to having at least one beam aimed directly under the gate opening. This ADCP was deployed in Bay 5. The second ADCP operated at $1200 \mathrm{kHz}$ and was deployed in a fixed position throughout the study. This unit was angled in the position shown in Figure 3.16, where the centerline beams were approximately 20-deg off vertical (70-deg from horizontal with the water surface, as noted in the figure). This unit was deployed in Bay 3. Each unit frequency was selected for a particular purpose: the $600 \mathrm{kHz}$ is capable of measurement more than twice the $1200 \mathrm{kHz}$ distance; however, the bin sizes must be larger (roughly twice) to achieve the same Doppler error. It was for this reason that the $600-\mathrm{kHz}$ unit was placed on the rotator to sweep large swaths in front of the spill bay entrance, while the $1200 \mathrm{kHz}$ was focused primarily over the ogee crest. Equipment limitations prevented rotators from being attached to both ADCPs. The dataset collected by these two instruments was extensive. During the approximately one-week sampling period, a large range of spill conditions occurred, several of which were six or more hours in length (Table 3.5).

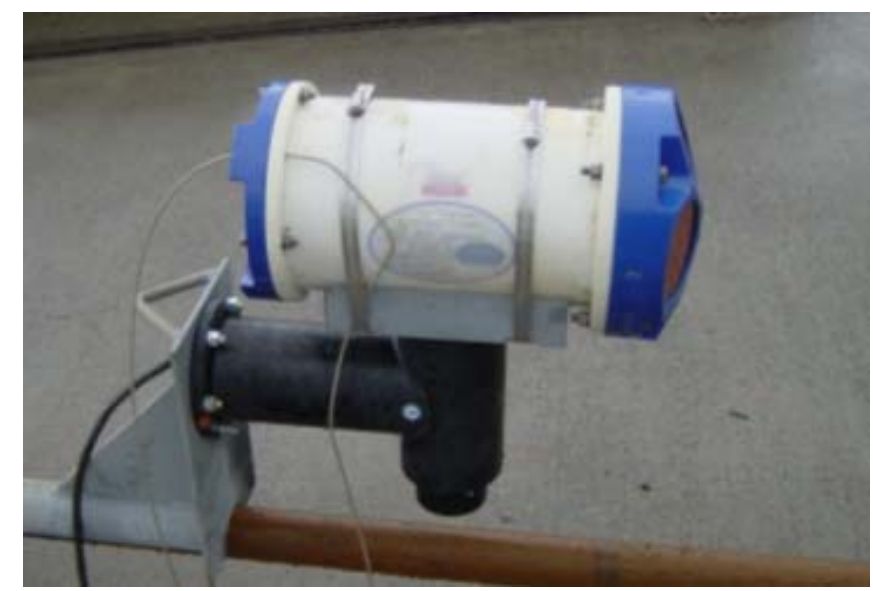

Figure 3.15. $600 \mathrm{kHz}$ ADCP Mounted on a Rotator. Only a single axis of rotation was used to rotate the ADCP beams into the forebay or back toward the Tainter gate. 
Table 3.5. Spillway Operations Sampled by ADCP. Discharge per bay was constant for Spill Bays 1-6 during the sampling period. The final case in the table $(8.5 \mathrm{ft}$ gate height/93 $\mathrm{kcfs})$ was the only sampling when seven bays were spilling.

\begin{tabular}{|c|c|c|c|}
\hline $\begin{array}{c}\text { Gate Opening } \\
(\mathrm{ft})\end{array}$ & $\begin{array}{c}\text { Discharge per Bay } \\
(\mathrm{cfs})\end{array}$ & $\begin{array}{c}\text { Forebay Water Surface Elev. } \\
(\mathrm{ft})\end{array}$ & $\begin{array}{c}\text { Spillway Discharge } \\
(\mathrm{kcfs})\end{array}$ \\
\hline 4.5 & 6,650 & 159.1 & 40 \\
\hline 6.5 & 9,600 & 159.1 & 57 \\
\hline 8.5 & 12,200 & 157.7 & 73 \\
\hline 8.5 & 12,400 & 158.5 & 93 \\
\hline
\end{tabular}

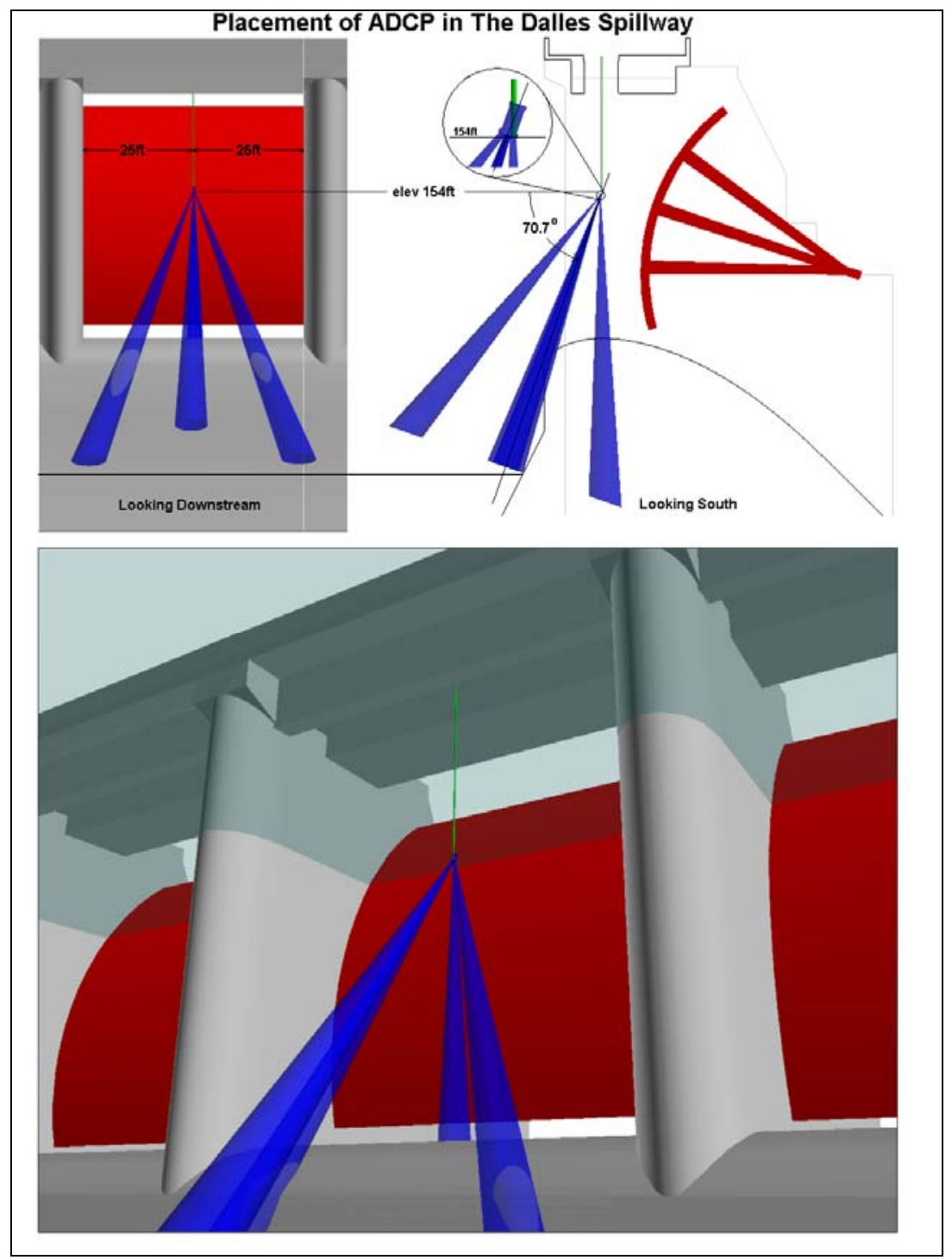

Figure 3.16. Schematic of the ADCP Deployment at the Spillway. 
Hydroacoustic Evaluation of Juvenile Salmonid Passage at The Dalles Dam in 2004 


\subsection{Results}

We organized the results from the hydroacoustic study at The Dalles Dam in 2004 into three main sections: environmental conditions, fish passage evaluation, and sluiceway evaluation.

\subsection{Environmental Conditions}

This section contains a description of the environmental conditions during the study in 2004, including smolt migration characteristics, river discharge, and hydraulic conditions.

\subsubsection{Smolt Migration Characteristics}

Juvenile salmonid monitoring is not conducted at The Dalles Dam. Therefore data on smolt migration characteristics there are based on the Smolt Monitoring Program's (SMP) sampling at John Day Dam and information on hatchery releases in the Deschutes River drainage. John Day Dam is the nearest upstream dam with smolt monitoring facilities. It is generally representative of species composition and run timing at The Dalles Dam because the travel time from John Day Dam to The Dalles Dam is about $1 \mathrm{~d}$ based on radio telemetry data (J. Beeman, USGS-BRD, pers. comm.). There is only one significant tributary between the two dams. This tributary, the Deschutes River, has a juvenile salmonid migration that includes approximately 1 million hatchery yearling Chinook salmon. Overall at The Dalles Dam, yearling salmon and steelhead dominate the downstream migration during spring, while subyearling Chinook salmon dominate the run during summer.

Our study encompassed the majority of the migration period for yearling (stream-type) Chinook (Oncorhyncus tshawytscha), coho (O. kisutch), and sockeye (O. nerka) salmon as well as steelhead (O. mykiss) and subyearling (ocean-type) Chinook salmon (Figure 4.1). Passage of yearling fish peaked in mid- to late May (Figure 4.1). Passage of subyearling Chinook salmon, the most abundant salmonid fish migrating downstream through John Day Dam, peaked at the end of June. During the spring study period (April 19 to June 5), species composition was:

- yearling Chinook (60\%) salmon

- $\quad$ steelhead $(16 \%)$

- $\quad$ sockeye (11\%)

- $\operatorname{coho}(9 \%)$.

During the summer study period (June 6 to July 17), subyearling Chinook salmon comprised 89\% of the outmigration. 


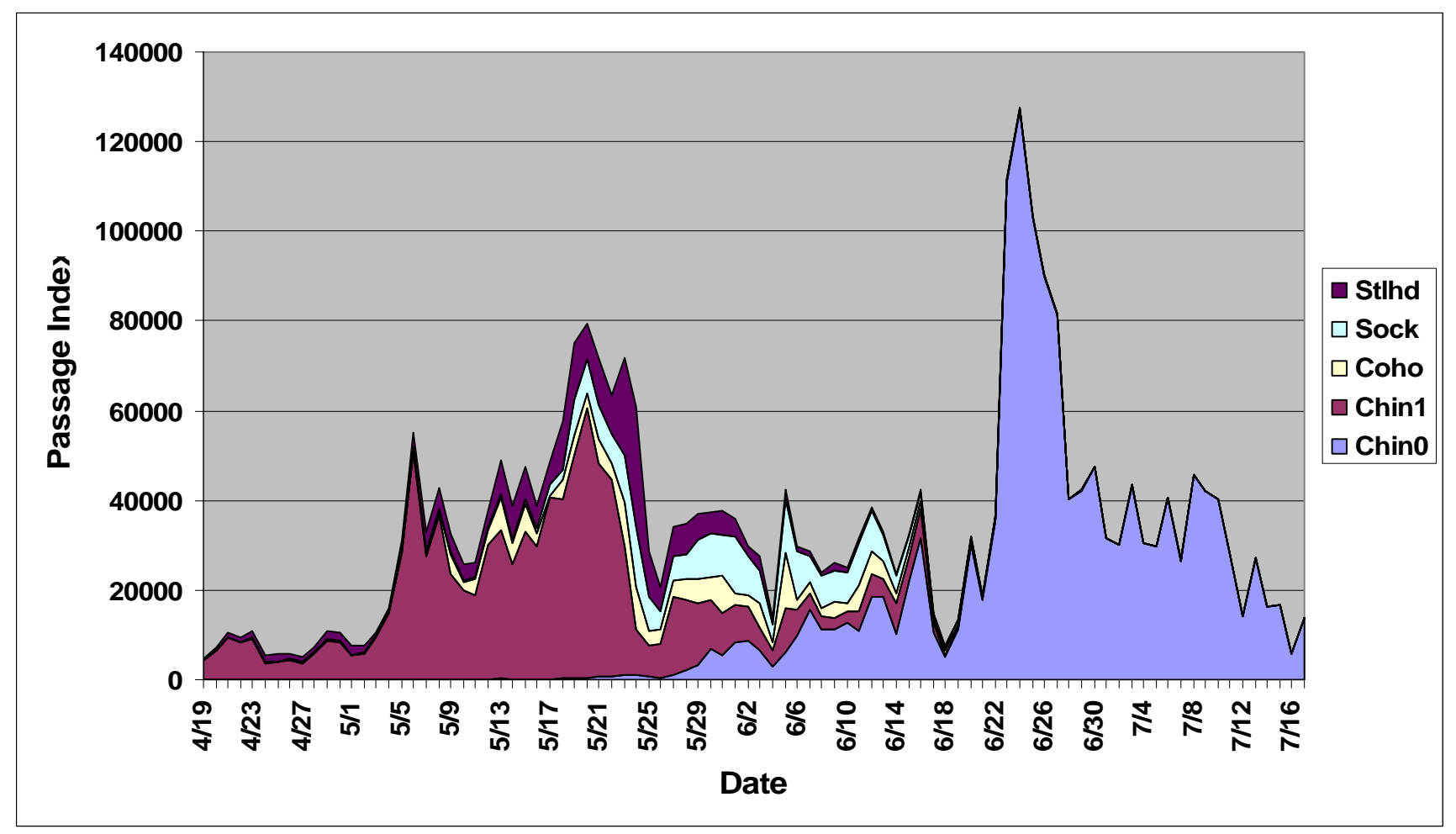

Figure 4.1. Smolt Monitoring Program (SMP) Passage Index for April 19 - July 17, 2004, from John Day Dam. Designations in the legend are for total fish passage (Total), subyearling Chinook salmon (Chinook 0), yearling Chinook salmon (Chinook 1), coho salmon (Coho), sockeye salmon (hatchery and wild), and steelhead. Data were obtained from DART (http://www.cqs.washington.edu/dart/dart.html), accessed in September 2004.

\subsubsection{River Discharge, Forebay Elevation, Temperature, and Turbidity}

During the study (April 19 through July 17), daily outflow at TDA ranged from 124 to $289 \mathrm{kcfs}$ (Figure 4.2). Mean daily outflow was $209 \mathrm{kcfs}$ in spring (April 19 to June 5) and $189 \mathrm{kcfs}$ in summer (June 6 to July 17). Outflow peaked in early June. During the 2004 study, total project outflow was $76 \%$ of the 10 -year average for spring and $77 \%$ of the 10 -year average for summer. Daily powerhouse discharge averaged $122 \mathrm{kcfs}$ in spring and $110 \mathrm{kcfs}$ in summer. Spill for fish protection commenced on April 12. Daily spill flow during our study ranged from 49 to $119 \mathrm{kcfs}$, with a mean of $82 \mathrm{kcfs}$ (39\% of total) in spring and $74 \mathrm{kcfs}(39 \%$ of total) in summer. Daily sluice flow ranged from about 3.0 to $4.6 \mathrm{kcfs}$, depending on experimental treatment and forebay elevation. In spring and summer, mean sluice discharge was $2.2 \%$ and $2.4 \%$ of total project discharge, respectively.

Power peaking occurred during 0400-1000 $\mathrm{h}$ and 1800-2200 $\mathrm{h}$ (Figure 4.3). Turbine unit operations varied from hour to hour and day to day (Figures 4.4 and 4.5). As noted above, MU 3, 5, 6 , and 7 were off-line during the entire study. MU 1 and 2 went off-line unexpectedly in early June. 


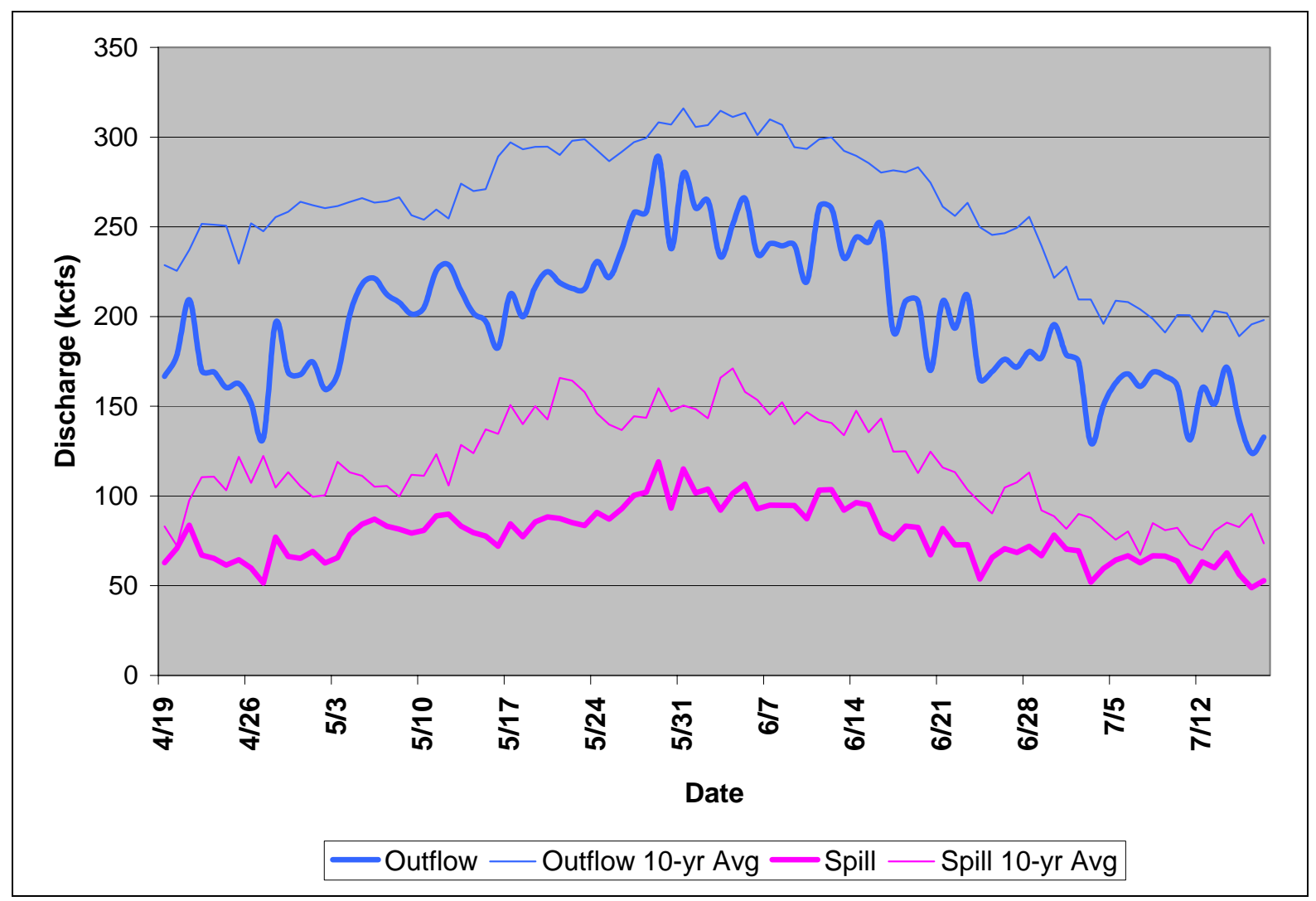

Figure 4.2. Daily Total Outflow and Spill for 2004 and the 10-yr Average (kcfs). Data were obtained from DART (http://www.cqs.washington.edu/dart/dart.html), accessed September 2004.

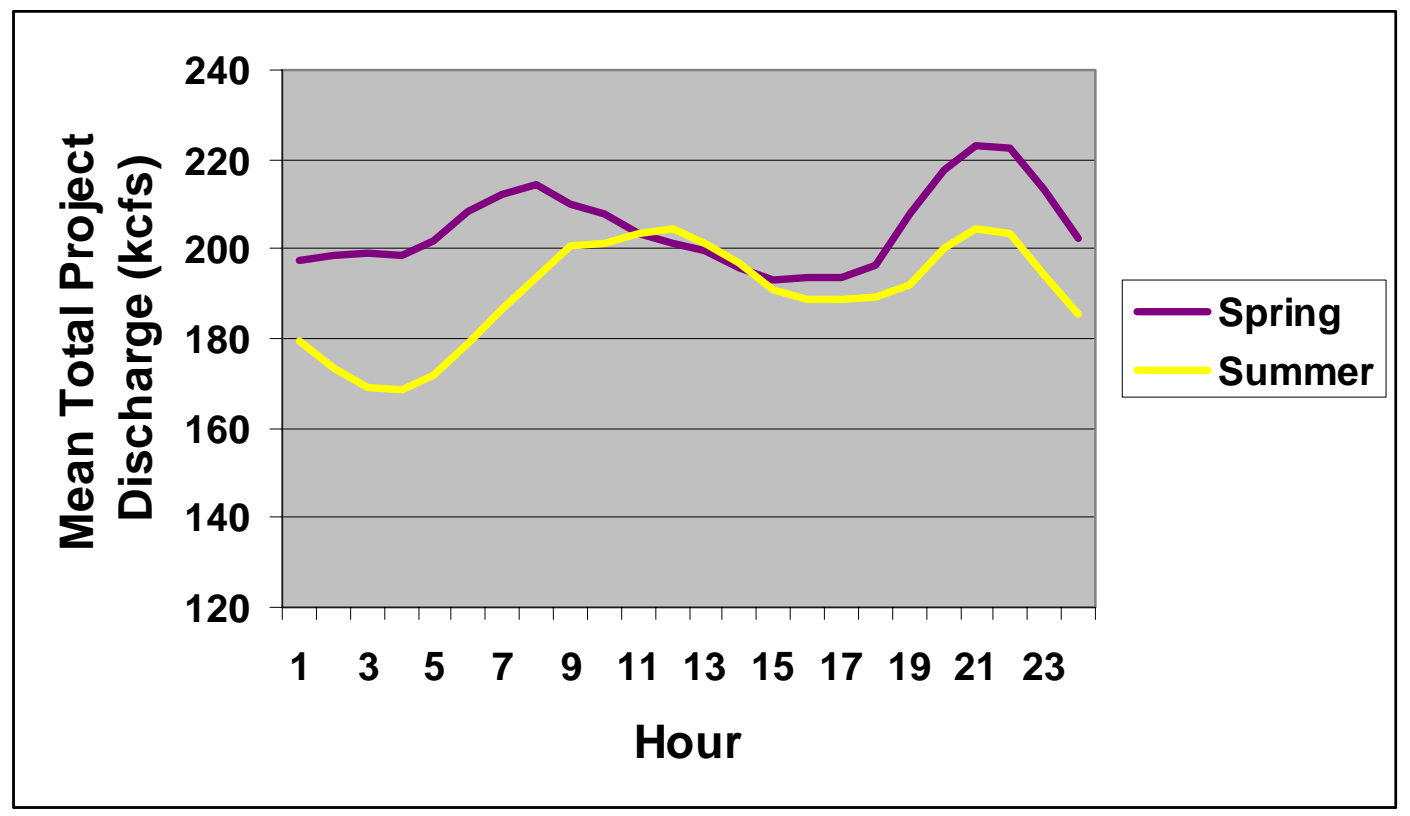

Figure 4.3. Diel Distribution of Total Project Discharge for Spring (4/19-6/5) and Summer (6/67/11) 2005. 


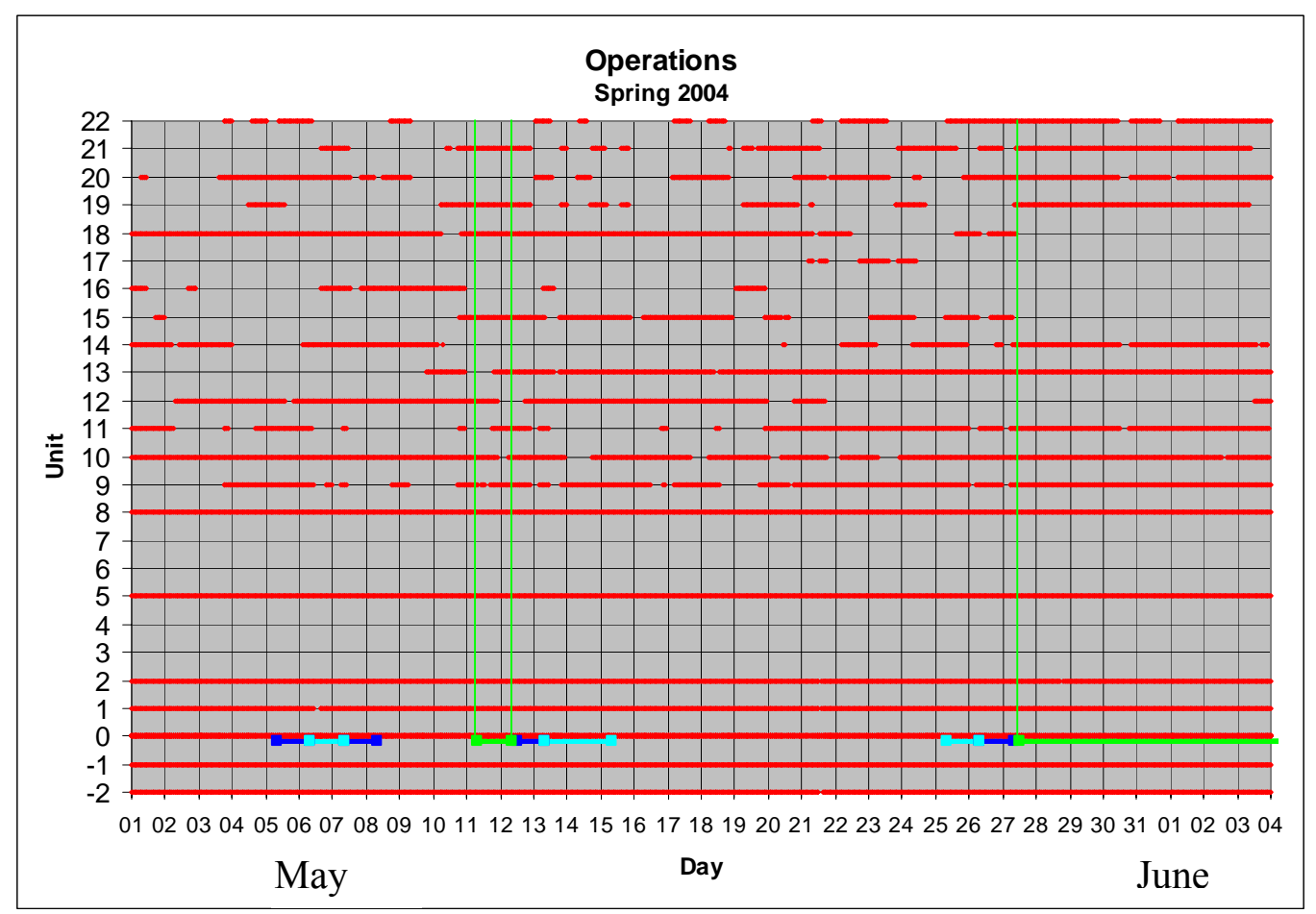

Figure 4.4. Project Operations in Spring 2004. Red lines denote on-line units, and dark and light blue lines denote DIDSON sampling at SL 1 during West only and West+East treatments, respectively. Green lines denote DIDSON sampling at SL 18.

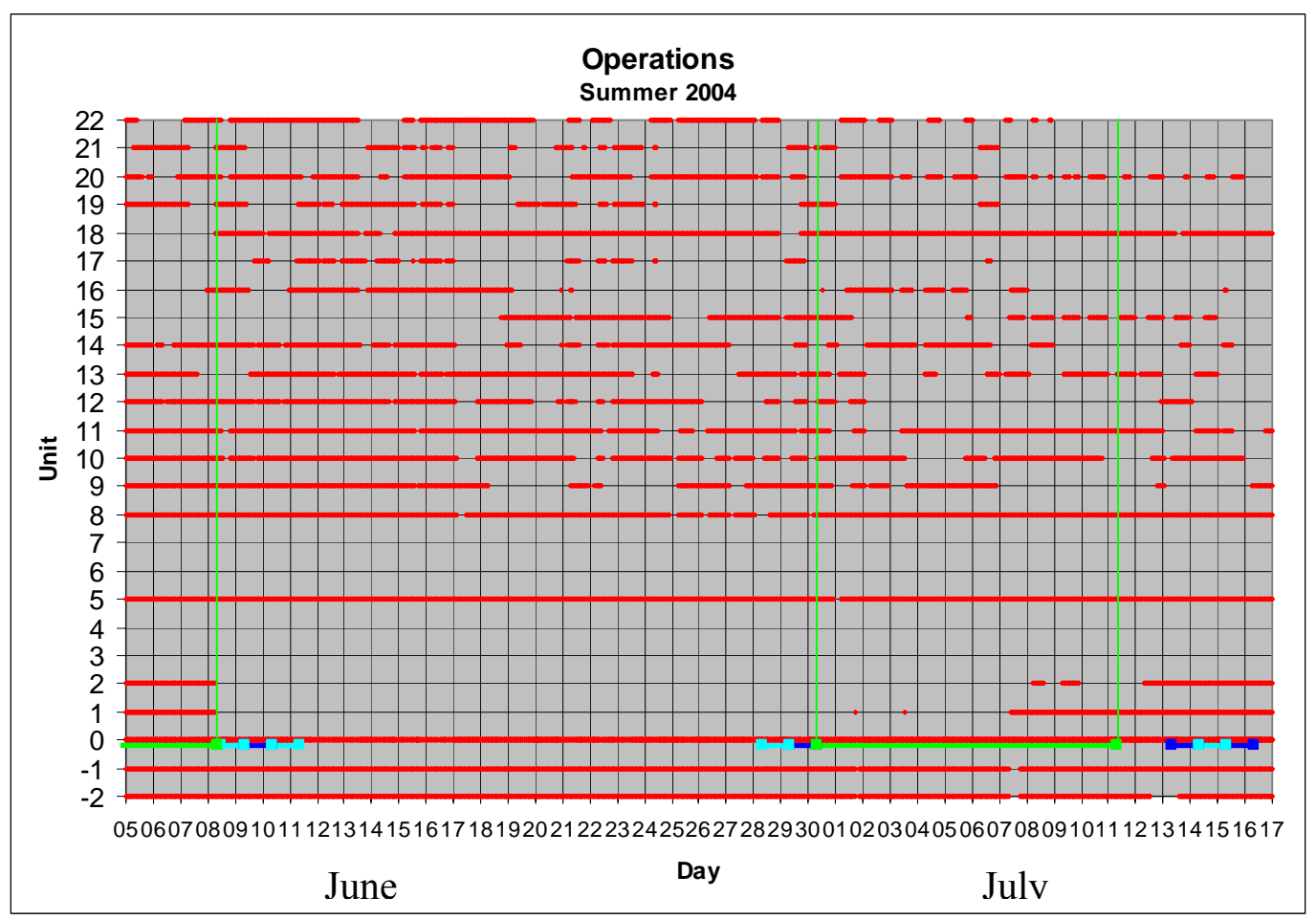

Figure 4.5. Project Operations in Summer 2004. Line colors are explained in Figure 4.4. 
Forebay elevation during the study ranged from $157.6 \mathrm{ft}$ to $159.3 \mathrm{ft}$ (Figure 4.6). Mean forebay elevation was $158.7 \mathrm{ft}$ in spring and $158.6 \mathrm{ft}$ in summer.

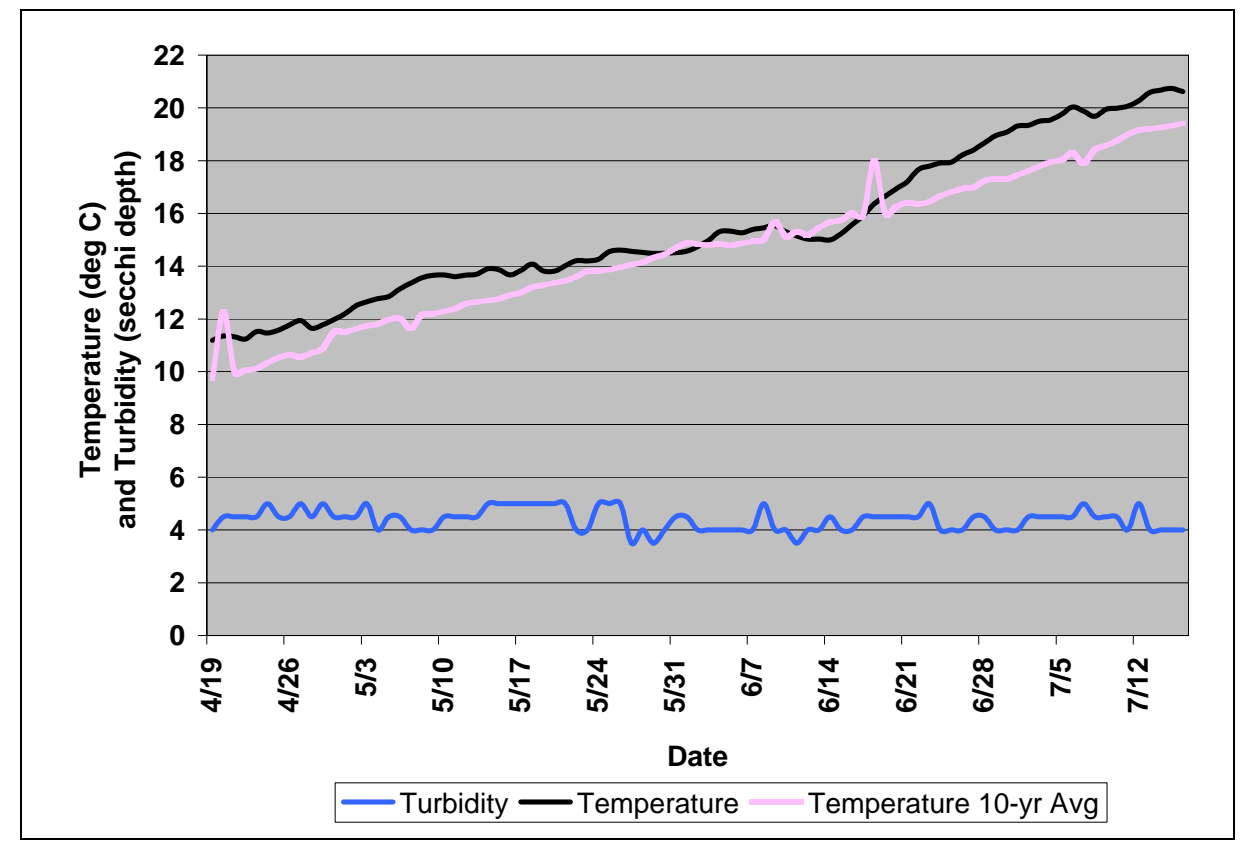

Figure 4.6. Mean Daily Forebay Elevation. Data were obtained from DART (http://www.cqs.washington.edu/dart/dart.html) in September 2004.

Water temperature generally increased as the study progressed (Figure 4.7). It ranged from 11.2 ${ }^{\circ} \mathrm{C}$ to $20.8{ }^{\circ} \mathrm{C}$ and was $0.8^{\circ} \mathrm{C}$ warmer than the 10 -year average in spring and $0.9{ }^{\circ} \mathrm{C}$ warmer in summer. Turbidity was generally low, as secchi depth readings were about 4 to $5 \mathrm{ft}$ (Figure 4.7).

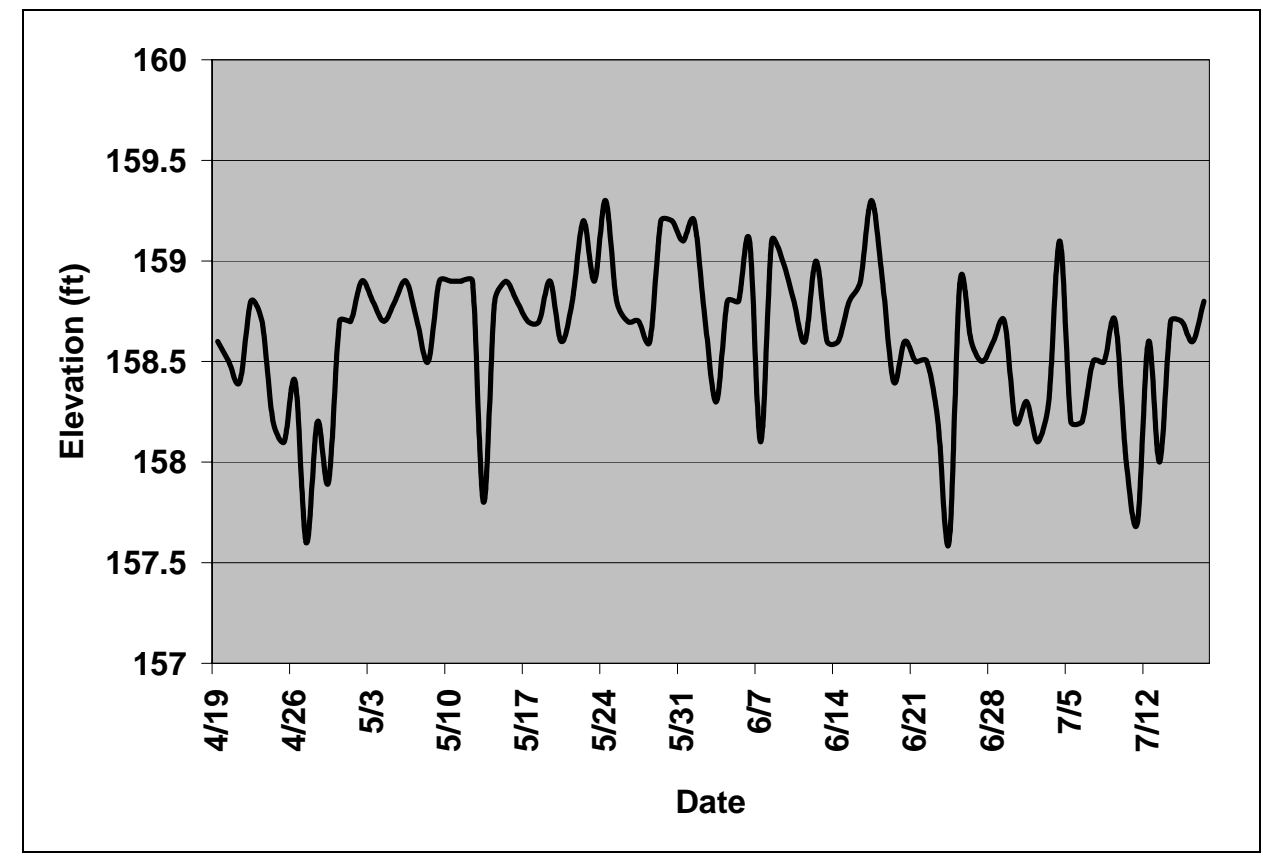

Figure 4.7. Mean Daily Temperature and Turbidity for April 19 - July 17, 2004, at TDA. Data were obtained from DART (http://www.cqs.washington.edu/dart/dart.html) in September 2004. 


\subsubsection{Hydraulic Conditions}

\section{Forebay CFD}

All eight discharge scenarios we modeled (Table 3.3) produced similar results at the broad scale reported in this section. Therefore we chose Scenario AWE as "typical." As revealed by CFD modeling, forebay velocities were generally less than $2 \mathrm{fps}$, except near the spillway (Figure 4.8) turbine unit trashracks (Figure 4.9), and sluiceway entrances (Figure 4.10). Surface flow at $3.5 \mathrm{ft}$ below mean forebay elevation was toward the spillway in the outer (northern) two-thirds of the forebay out from the powerhouse (Figure 4.8); it was angled toward the powerhouse in the inner onethird. At deeper depths than shown here, more of the flow would be toward the powerhouse.

Velocities in the forebay of MU 1-2 and MU 18-2 during the West+East condition were similar (Figure 4.9). The flow nets for SL 1 was somewhat larger than that for SL 18; the flows into these entrance were 2,690 cfs and 1,800 cfs, respectively (see Table 2.1). Water velocities in the forebay were flat except near the turbine intake trashracks (Figure 4.9).

Flow into the sluiceway had gradual acceleration until it was over the sill, then it accelerated rapidly into the channel (Figure 4.10).

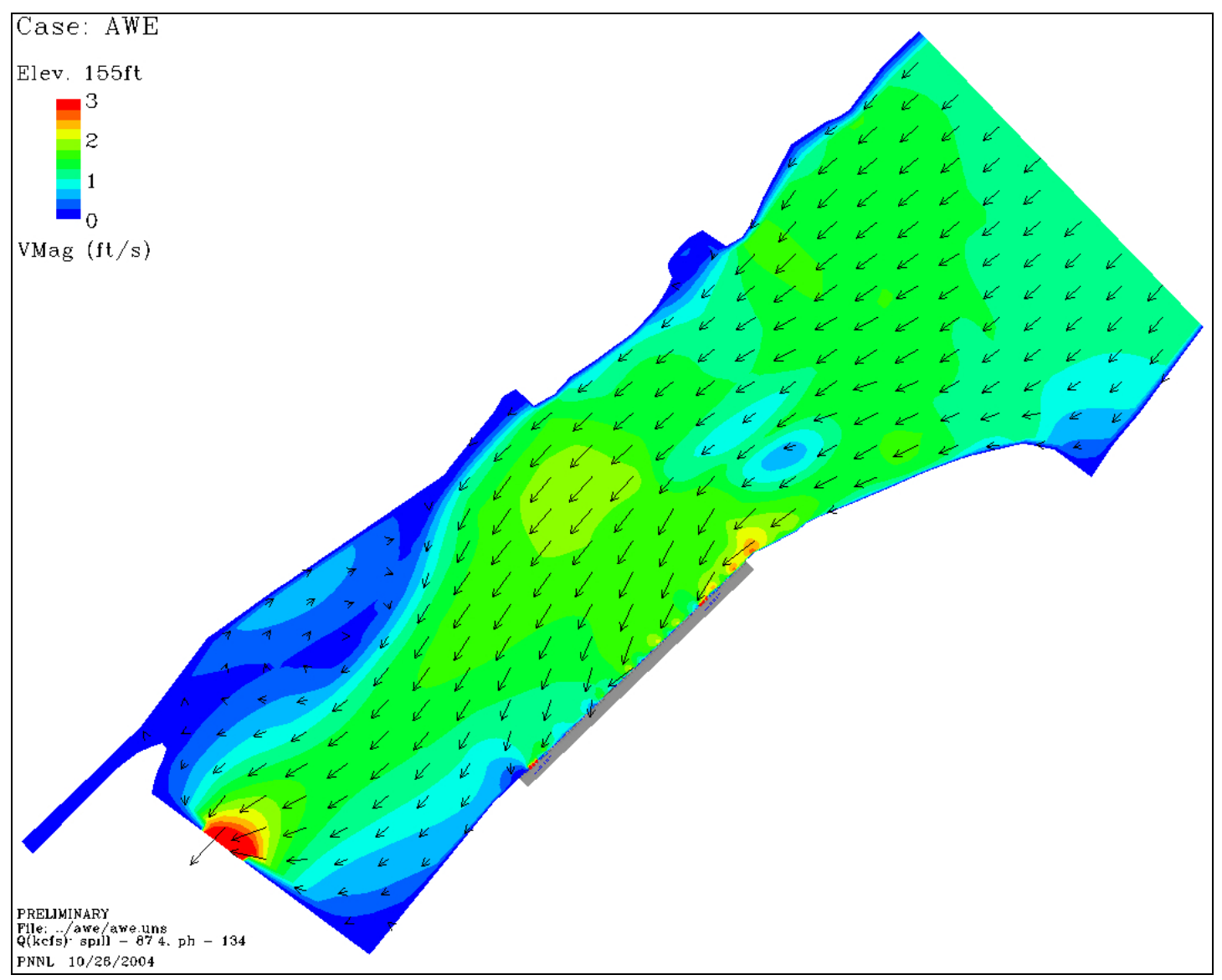

Figure 4.8. Plan View of the Forebay Velocities from a CFD Model. Data are for the AWE scenario (see Table 3.4) at elevation $155 \mathrm{ft}$. 


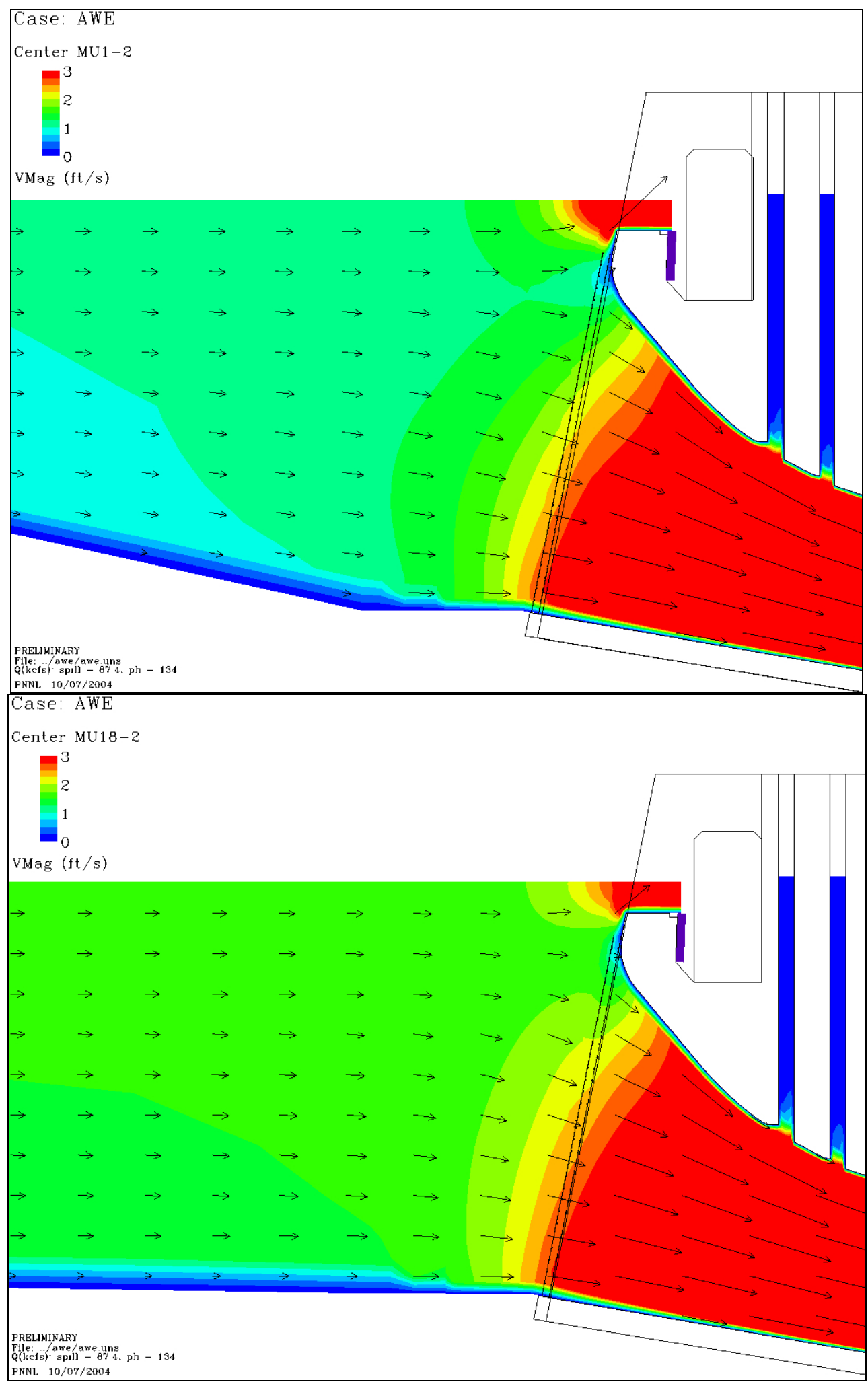

Figure 4.9. Side View of the Forebay Velocities from a CFD Model. Data are for the AWE scenario (see Table 3.4) at the centerline of MU 1-2 (top) and MU 18-2 (bottom). 


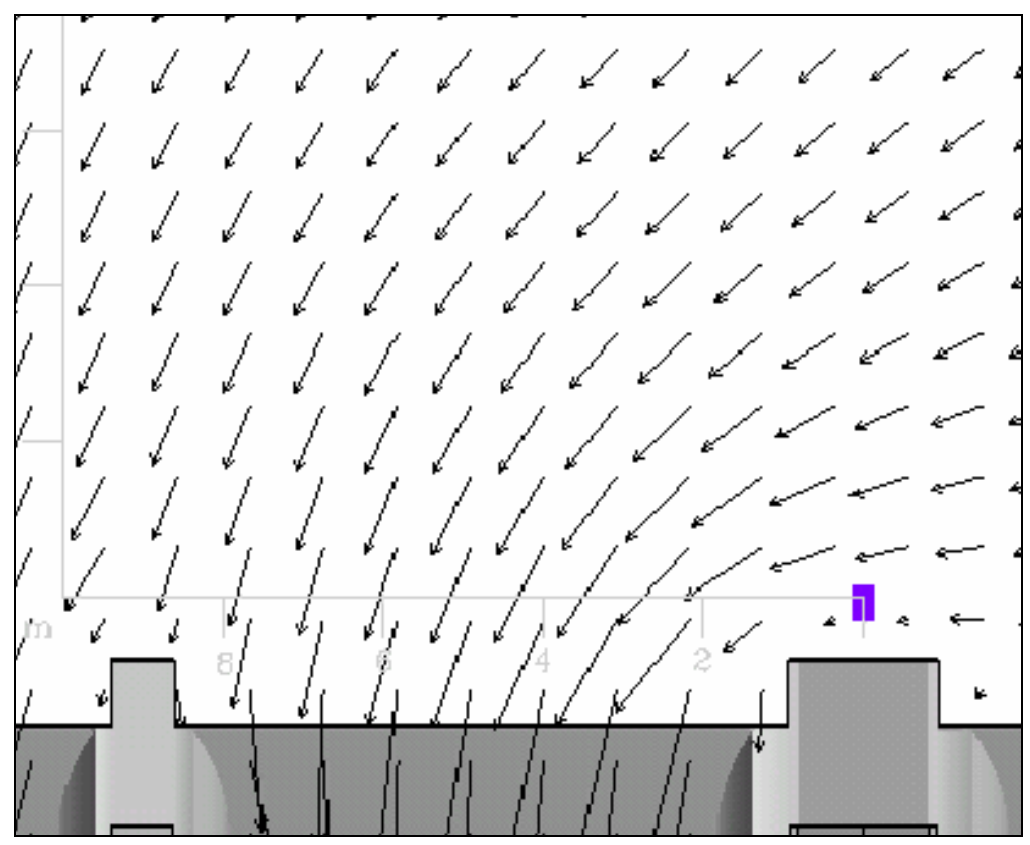

Figure 4.10. Plan View of CFD Data for the Forebay of Sluice 1-3 during the West-Only Treatment. The purple box represents the DIDSON.

\section{Powerhouse ADCP}

Six data blocks were used to portray the powerhouse ADCP results (Table 4.1). These blocks corresponded to periods when DIDSON fish tracks were also analyzed during the period May 25 to July 1, 2004 (see Table 3.3). Figures 4.11-4.16 show graphical results of the time series of water velocities (Beam 1) at the sluiceways at MU 1 and MU 18.

At MU 1 velocities were temporally homogeneous except during June 28-30. That period shows a day and night difference that possibly corresponded to dam operations. Individually, day and night periods were homogeneous (Figure 4.13).

At MU 18, Figure 4.14 shows an apparent change that could be explained by RDI BBList software reversing the range series of data prior to May 27, $1653 \mathrm{~h}$ (Julian Date 148.7). If this part of the series were reversed, then the period would show relative temporal homogeneity in velocity as measured by Beam 1. Small velocity anomalies in the figure are probably reflective of data paucity. Figure 4.14 shows a gradual change in velocity and then a distinct change that could possibly be attributed to changing dam operations at $2200 \mathrm{~h}$ on June 7 . Gradual changes in velocity are noted in the last dataset at MU 18 (Figure 4.16).

In general, there was less temporal homogeneity at MU 18 (Figures 4.14 to 4.16) than at MU 1 (Figures 4.11 to 4.13). There was no distinct change in velocities at MU 1 as a result of SL 18 sluiceway flows. Note that SL 1 and 18 were both open from May 25 until May 26, $0800 \mathrm{~h}$, from June 8 to June $9,0800 \mathrm{~h}$ and from June 28 to June $29,0800 \mathrm{~h}$. Note: MU 18 was not sampled by an ADCP during these times but the day before or day after (see Table 4.1 for sampling schedule). Figure 4.12 does show a slight lessening of velocities around $0900 \mathrm{~h}$ on June 9 (Julian Date 161.4). However, velocities would be expected to increase when the SL 18 sluiceway was closed. 
Table 4.1. Data Blocks Used in ADCP Analysis at The Dalles Dam, May 25 to July 1, 2004. These blocks correspond to times (in Julian days) and locations for DIDSON fish tracking.

\begin{tabular}{|c|c|c|c|c|}
\hline Start & End & Julian Start & Julian End & Location \\
\hline May 25, 0900 h & May 27, 0759 h & 146 & 148 & 1 \\
\hline May 27, 0800 h & May 28, 0859 h & 148 & 149 & 18 \\
\hline June 7, 0800 h & June 8, 1759 h & 159 & 160 & 18 \\
\hline June 8, 1000 h & June 10,0900 h & 160 & 162 & 1 \\
\hline June 28, 0800 h & June 30, 0800 h & 180 & 182 & 1 \\
\hline June 30, 1000 h & July 1,0800 h & 182 & 183 & 18 \\
\hline
\end{tabular}

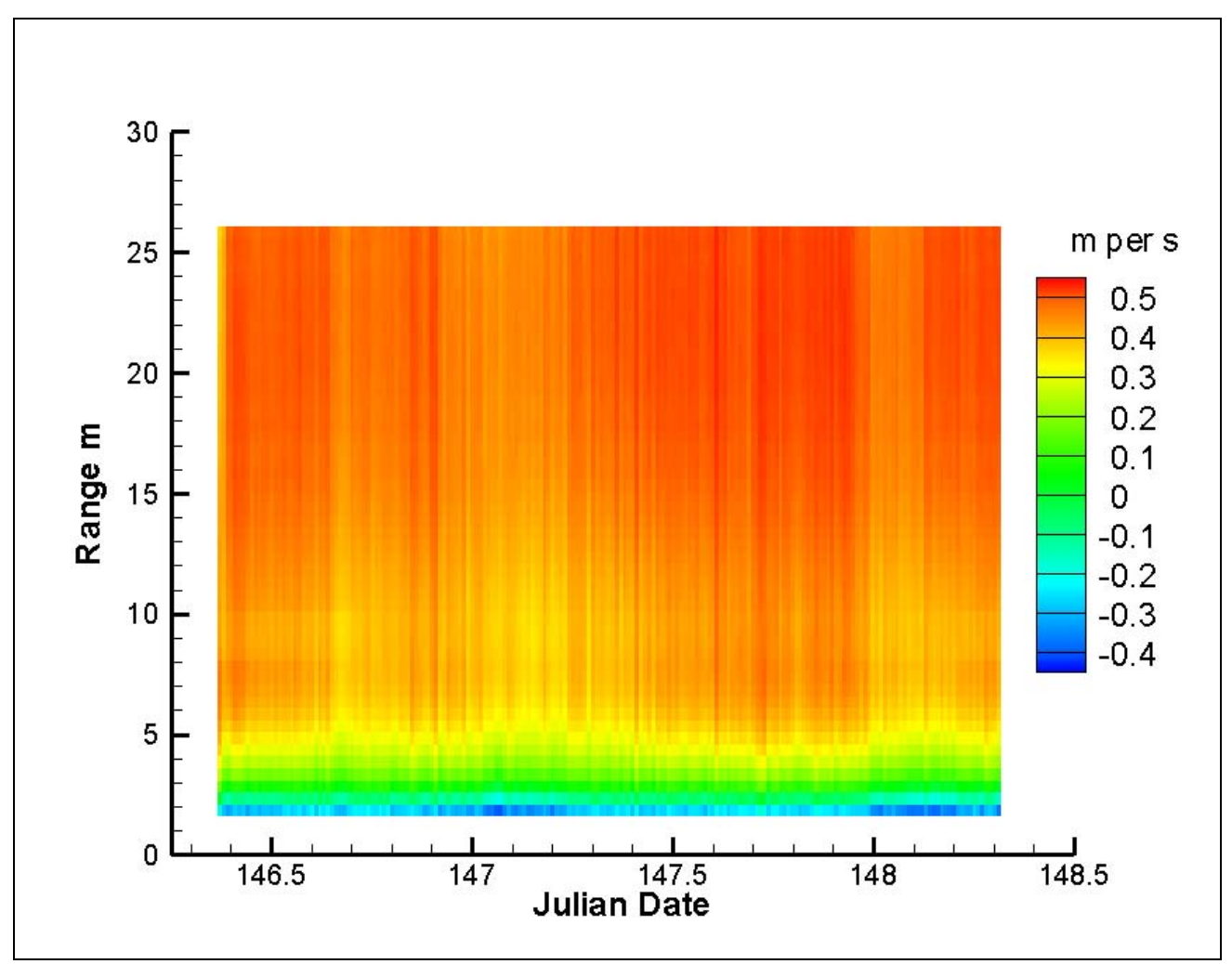

Figure 4.11. Velocities in Beam 1 (pointed 9 degrees down) at The Dalles Dam MU 1 Sluiceway, May 25-27, 2004. 


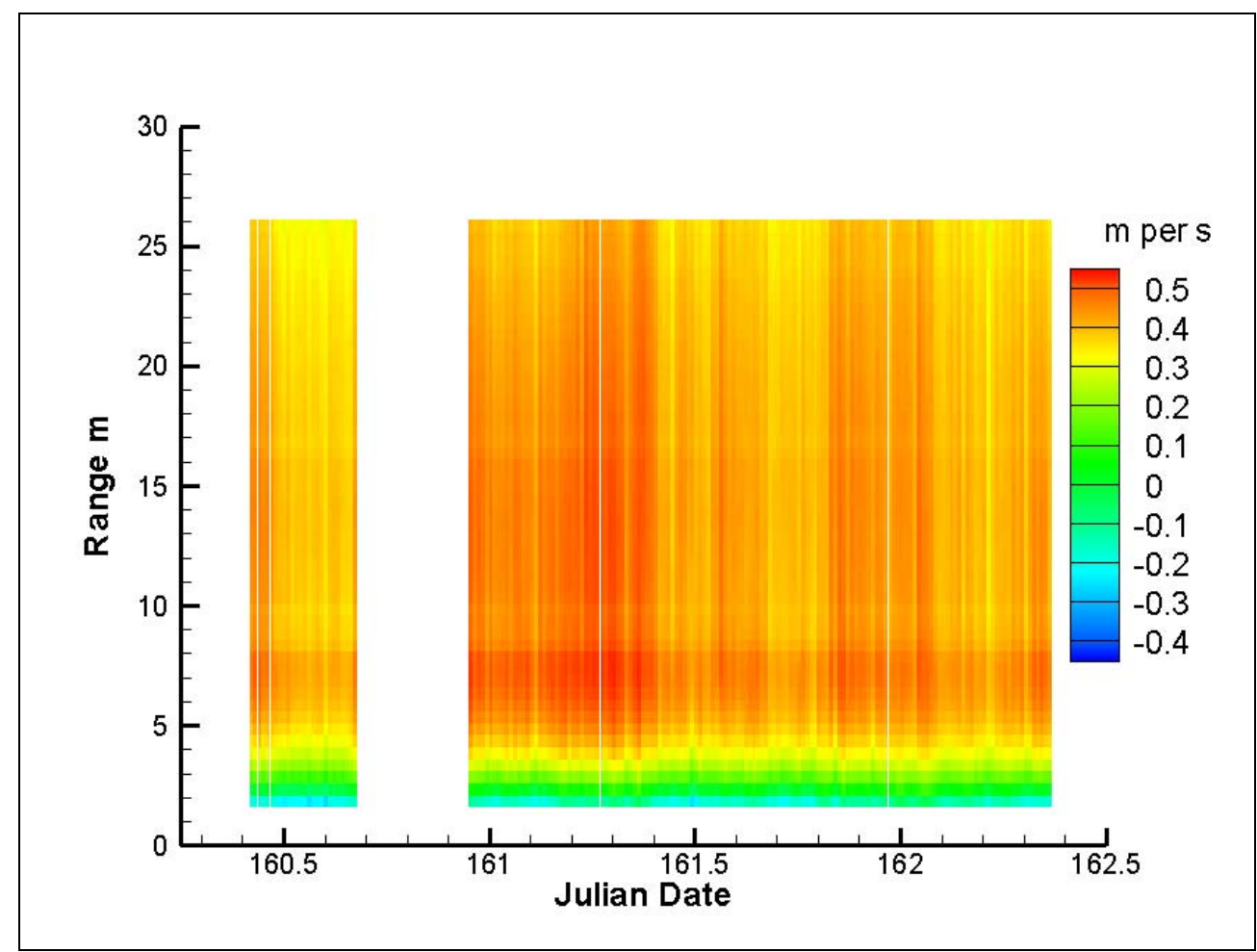

Figure 4.12. Velocities in Beam 1 (pointed 9 degrees down) at The Dalles Dam MU 1 Sluiceway, June 8-10, 2004.

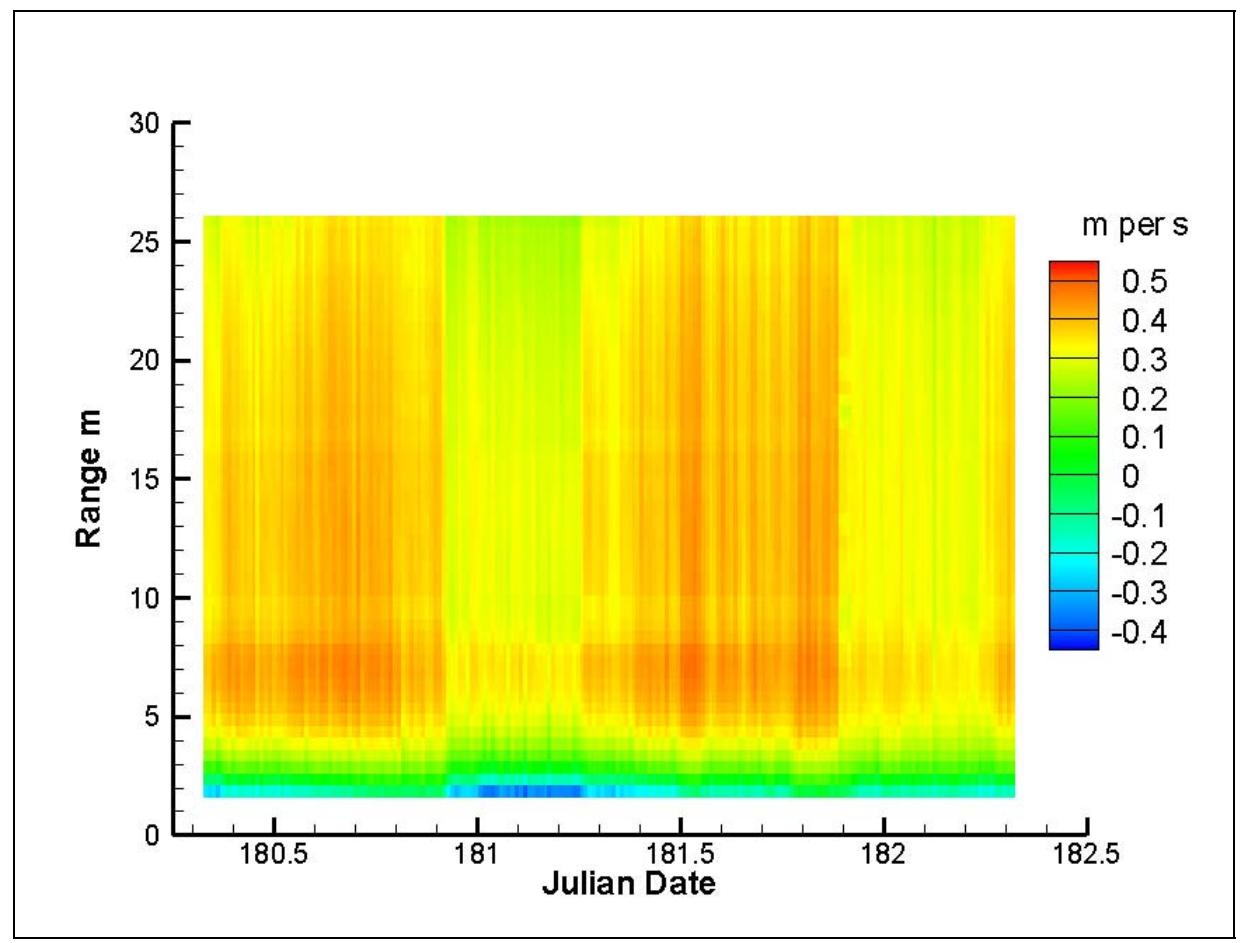

Figure 4.13. Velocities in Beam 1 (pointed 9 degrees down) at The Dalles Dam MU 1 Sluiceway, June 28-30, 2004. 


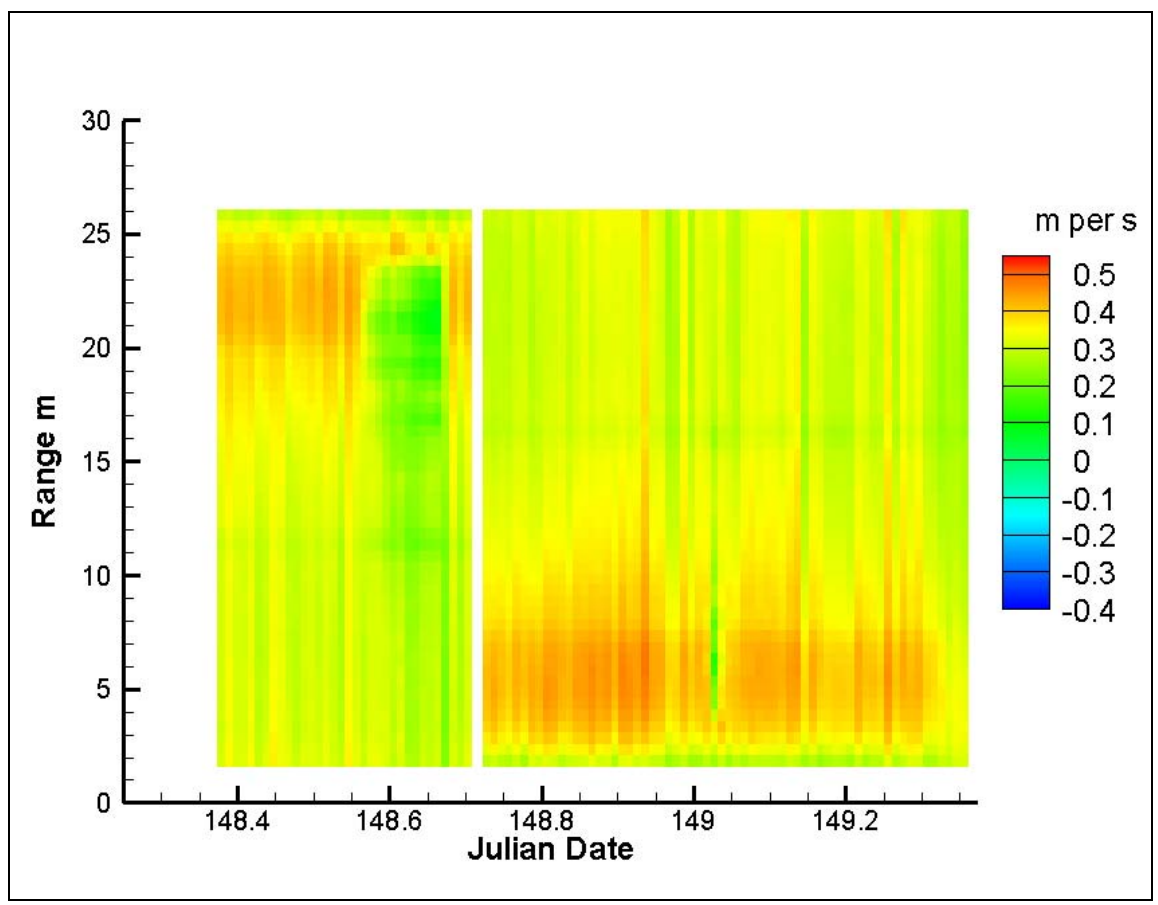

Figure 4.14. Velocities in Beam 1 (pointed 9 degrees down) at The Dalles Dam MU 18 Sluiceway, May 27-28, 2004.

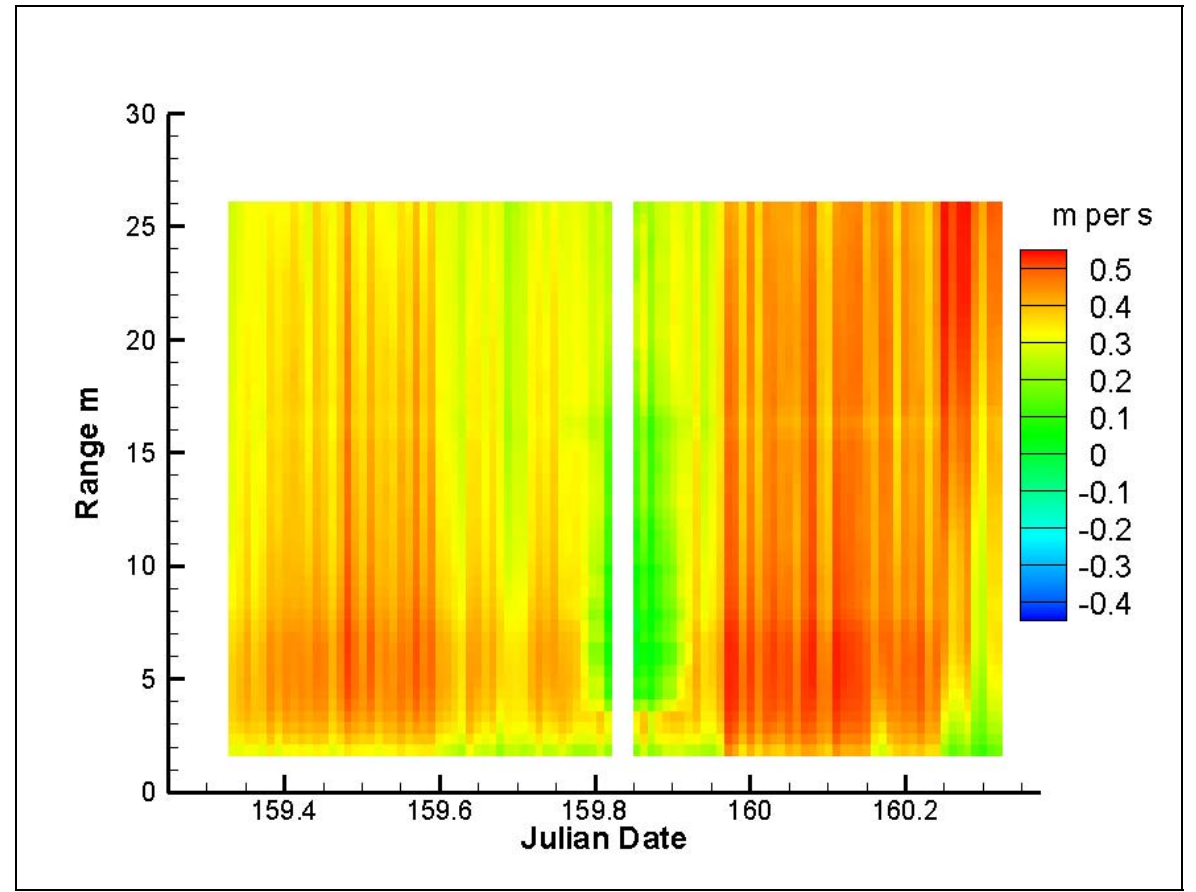

Figure 4.15. Velocities in Beam 1 (pointed 9 degrees down) at The Dalles Dam MU 18 Sluiceway, June 7-8, 2004. 


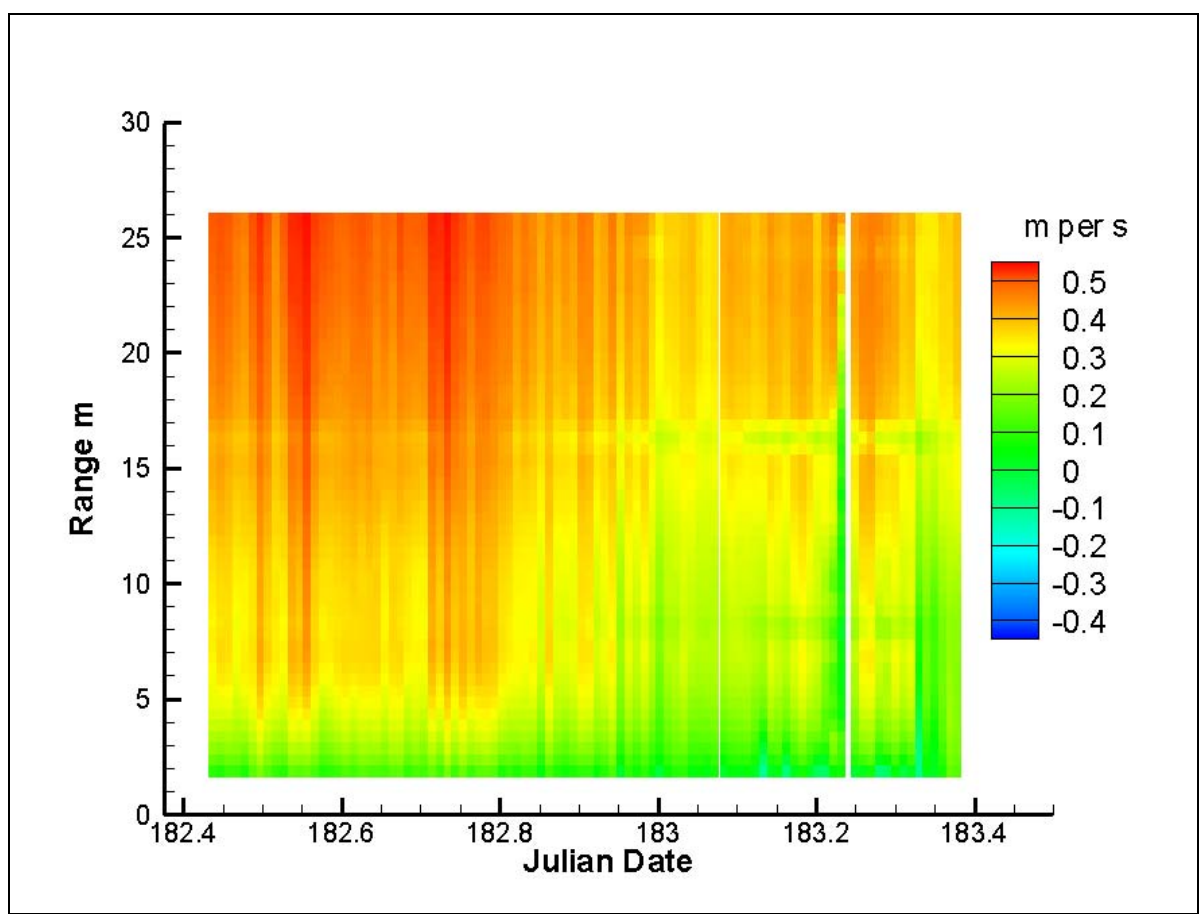

Figure 4.16. Velocities in Beam 1 (pointed 9 degrees down) at The Dalles Dam MU 18 Sluiceway, June 30 to July 1, 2004. 
Figures 4.17-4.19 show a comparison of the average velocities measured by Beam 1 under the two sluiceway operating conditions when the ADCP was located at SL 1. Forebay velocities at SL 1 were slightly $(0.02 \mathrm{~m} / \mathrm{s})$ lower at ranges 7 to $25 \mathrm{~m}$ from the ADCP when SL 18 was opened (West+East treatment) than when it was closed (West only treatment). Figure 4.20 shows average velocities for the three periods when the ADCP was located at SL 18. Velocities in the forebay of SL 18 varied among the sampling periods due to varying river flows and turbine operations.

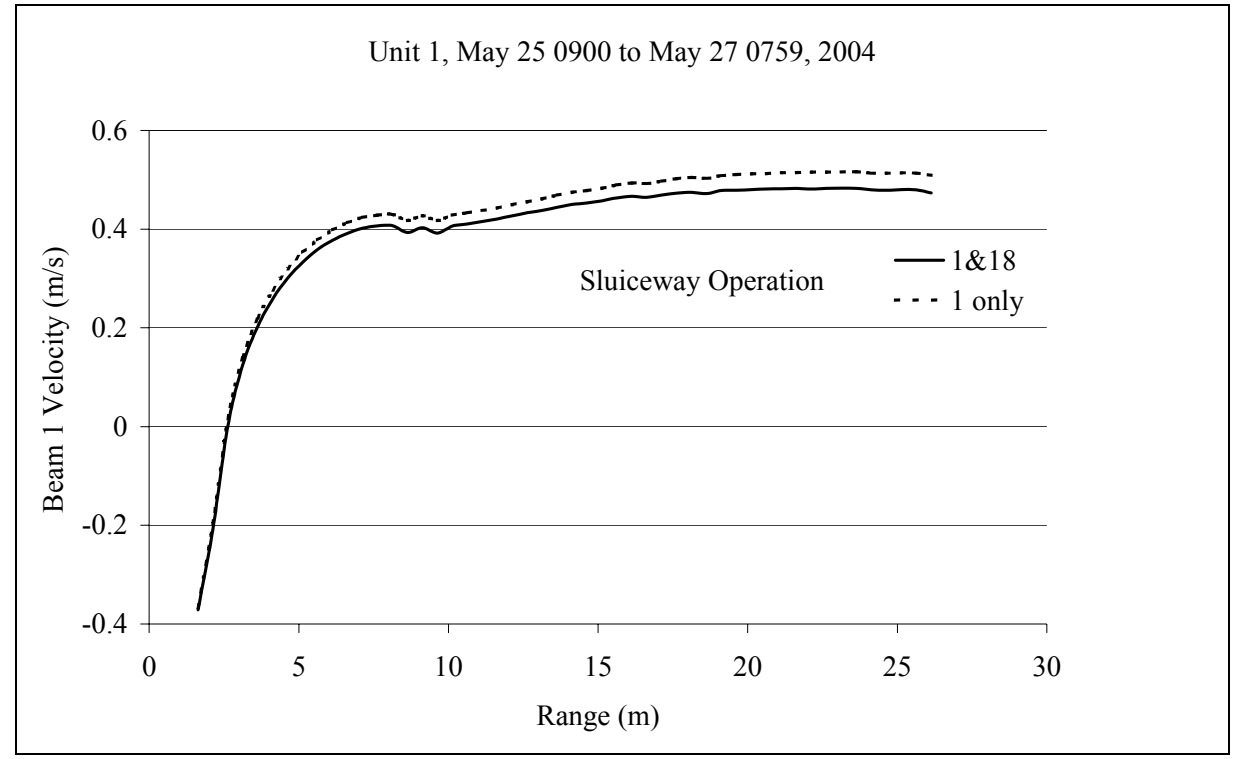

Figure 4.17. Average Velocities in ADCP Beam 1 (pointed 9 degrees down and 33 degrees out upstream) at The Dalles Dam MU 1 Sluiceway, May 25-27, 2004. "1\&18" is the West+East treatment and " 1 only" is the West only treatment.

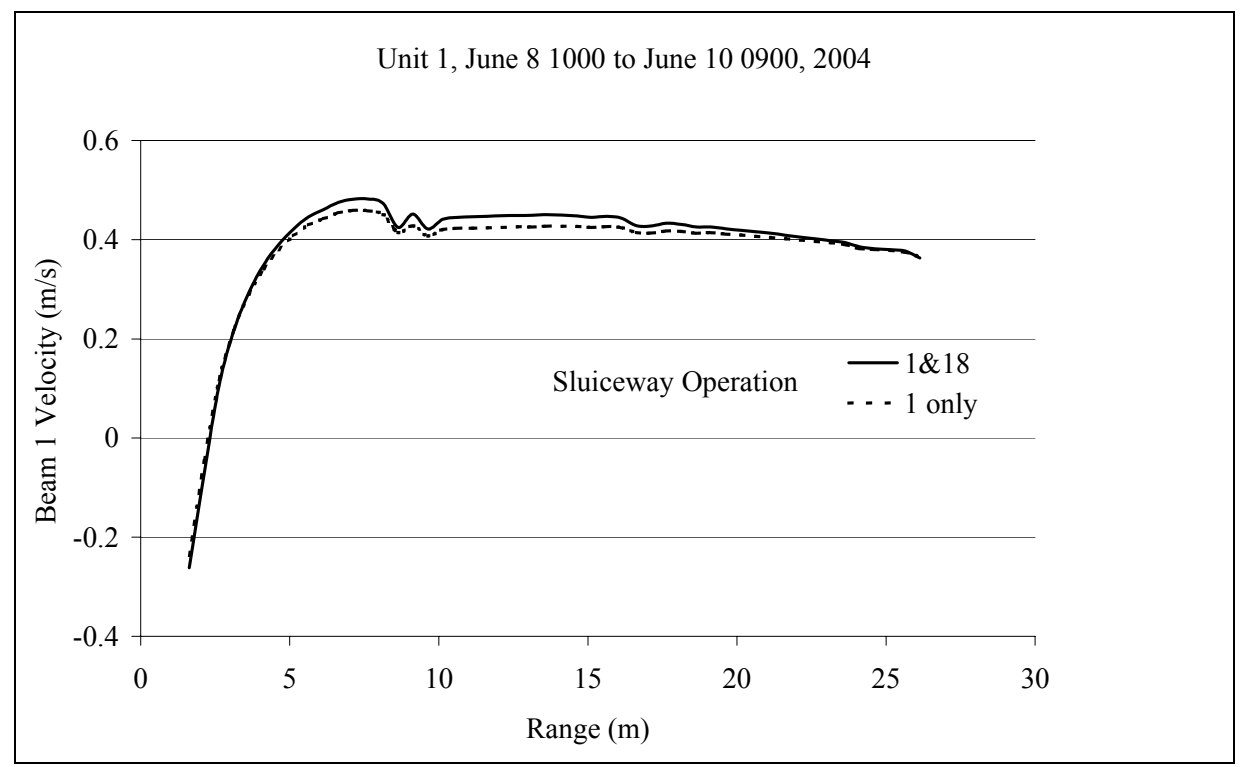

Figure 4.18. Average Velocities in ADCP Beam 1 (pointed 9 degrees down and 33 degrees out upstream) at The Dalles Dam MU 1 Sluiceway, June 8-10, 2004. "1\&18" is the West+East treatment and " 1 only" is the West only treatment. 


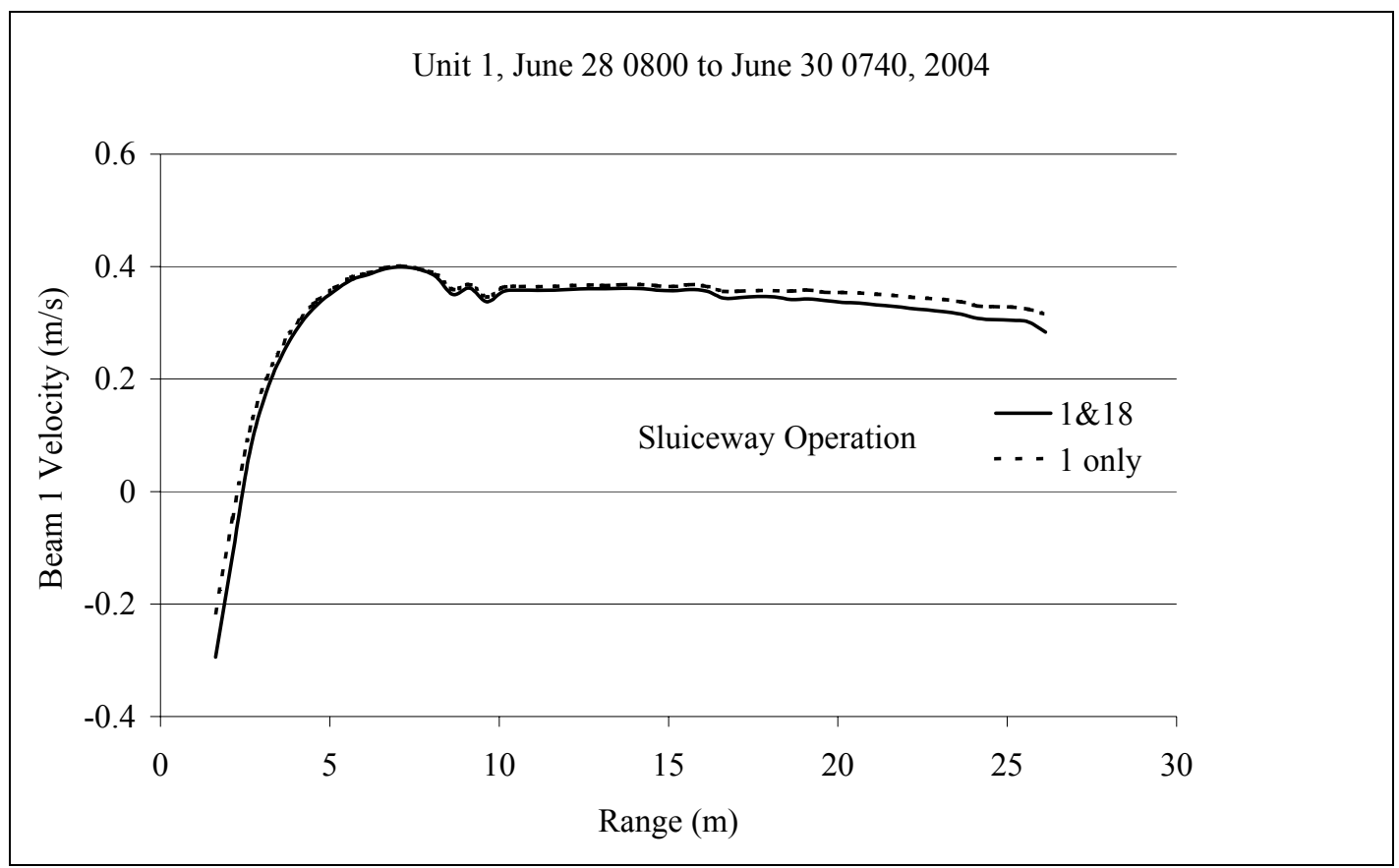

Figure 4.19. Average Velocities in ADCP Beam 1 (pointed 9 degrees down and 33 degrees out upstream) at The Dalles Dam MU 1 Sluiceway, June 28-30, 2004. "1\&18" is the West+East treatment and " 1 only" is the West only treatment.

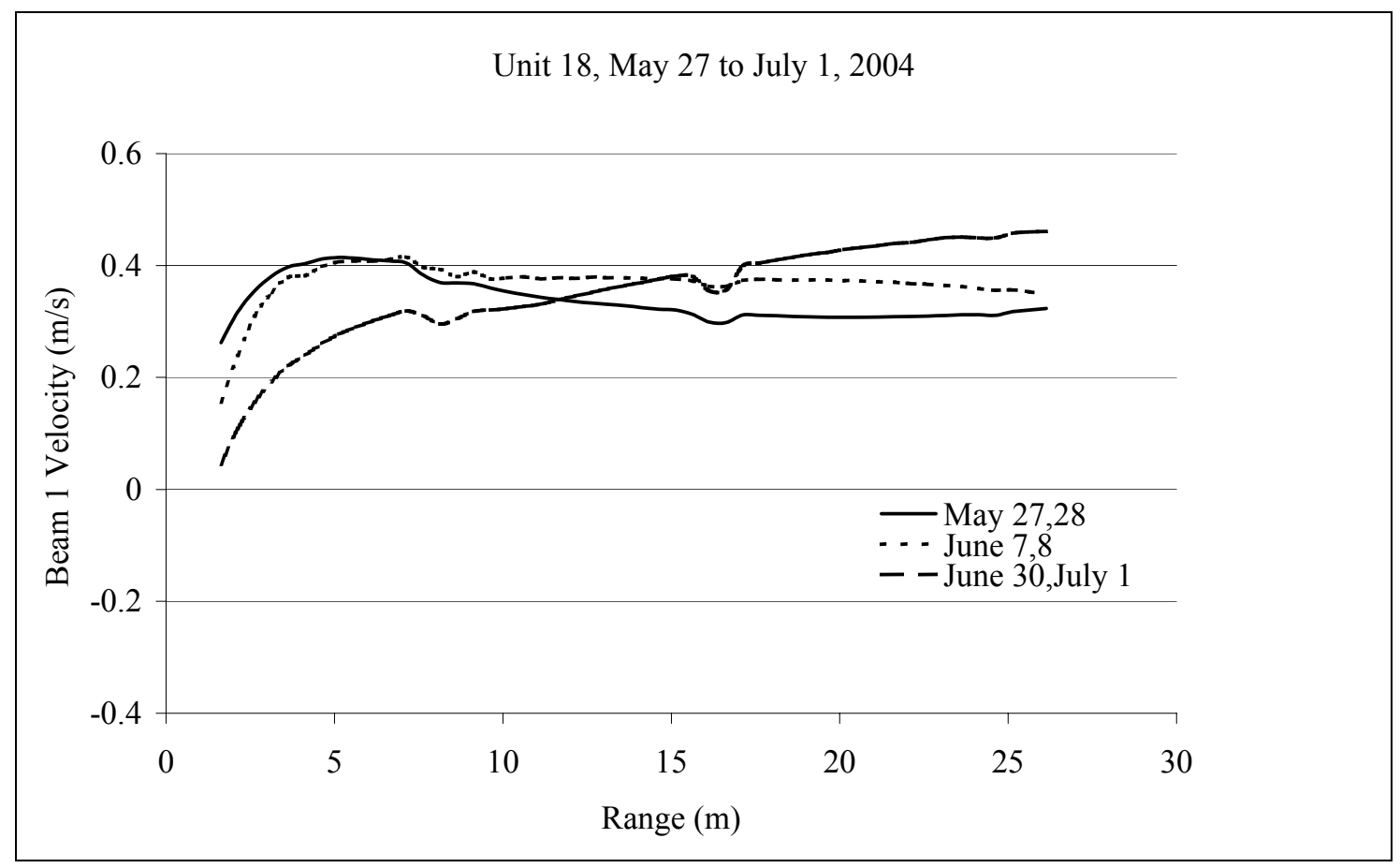

Figure 4.20. Average Velocities in ADCP Beam 1 (pointed 9 degrees down and 33 degrees out upstream) at The Dalles Dam MU 18 Sluiceway, May 27-July 1, 2004. Times corresponding to averages were $1730 \mathrm{~h}$ May 27 to $0859 \mathrm{~h}$ May 28, $0800 \mathrm{~h}$ June 7 to $1640 \mathrm{~h} \mathrm{June} \mathrm{8,} \mathrm{and} 1000$ h June 30 to 0800 h July 1. 
A time series of beam velocity data for a particular range from the powerhouse shows the temporal variability of velocity (Figures 4.21 and 4.22). Within a given 3-day sampling episode, velocity varied by about $0.1 \mathrm{~m} / \mathrm{s}$. Among the three sampling episodes, velocity varies by about $0.2 \mathrm{~m} / \mathrm{s}$. These data revealed the complex nature of the flow field in front of the TDA sluiceway entrances.

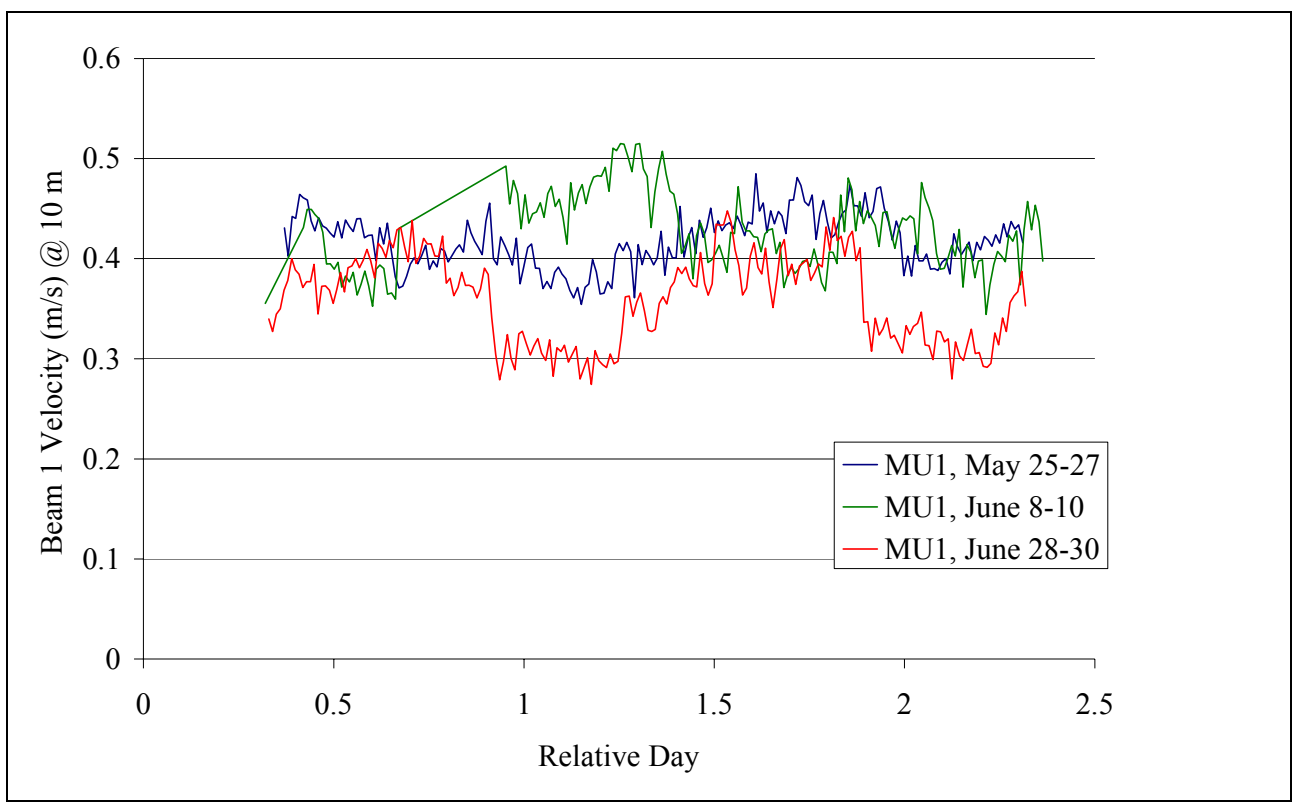

Figure 4.21. Beam 1 Velocities at $10 \mathrm{~m}$ from the ADCP at MU1 Sluiceway over Three Data Periods (see Table 4.1). Approximate position is $2.6 \mathrm{~m}$ deep and $6 \mathrm{~m}$ away from dam.

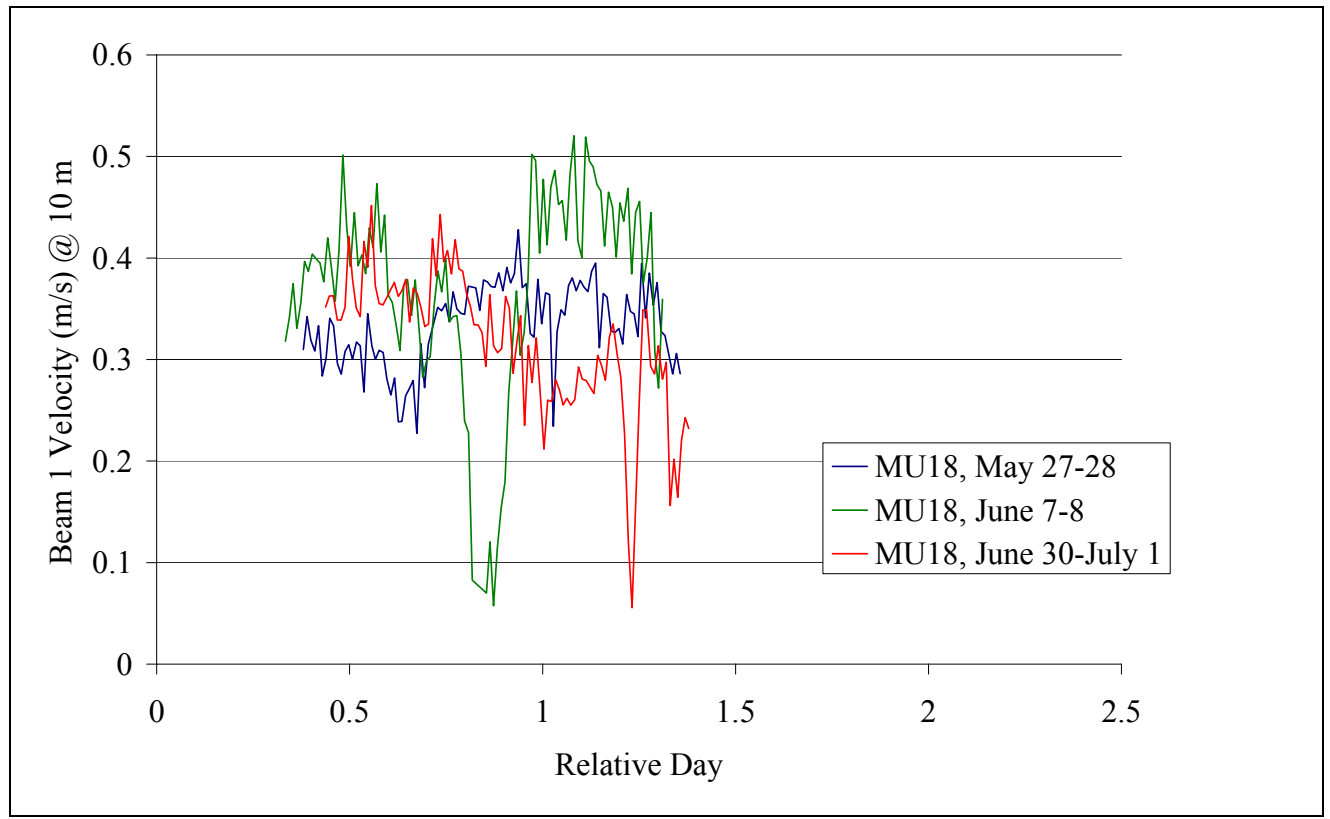

Figure 4.22. Beam 1 Velocities at $10 \mathrm{~m}$ from the ADCP at MU18 Sluiceway Over Three Data Periods (see Table 4.1). Approximate position is $2.6 \mathrm{~m}$ deep and $6 \mathrm{~m}$ away from dam. The two low-velocity spikes in the last two periods may be due to data insufficiency. 


\section{Spillway ADCP}

At present only the 6.5-ft gate opening 2004 results at The Dalles Dam spillway have been examined, and then only for the $600-\mathrm{kHz}$ unit, which had been rotated to a $7^{\circ}$ angle off vertical. At this angle, the ADCP was rotated such that the most downstream beam was pointing under the open gate. Data were also obtained at this gate opening at 20-, 17- 14-, 0, and minus 5-degrees from vertical. Velocity magnitudes in this zone were the largest, and this zone was most important for checking spillway CFD analyses for other projects. The results indicated an excellent match between CFD and ADCP data (Figures 4.23-4.25). Velocities along the axis of the typical hydroacoustic splitbeam transducer ranged from 1.7 to $25 \mathrm{fps}$ for the 6.5-ft gate opening (Figure 4.26).

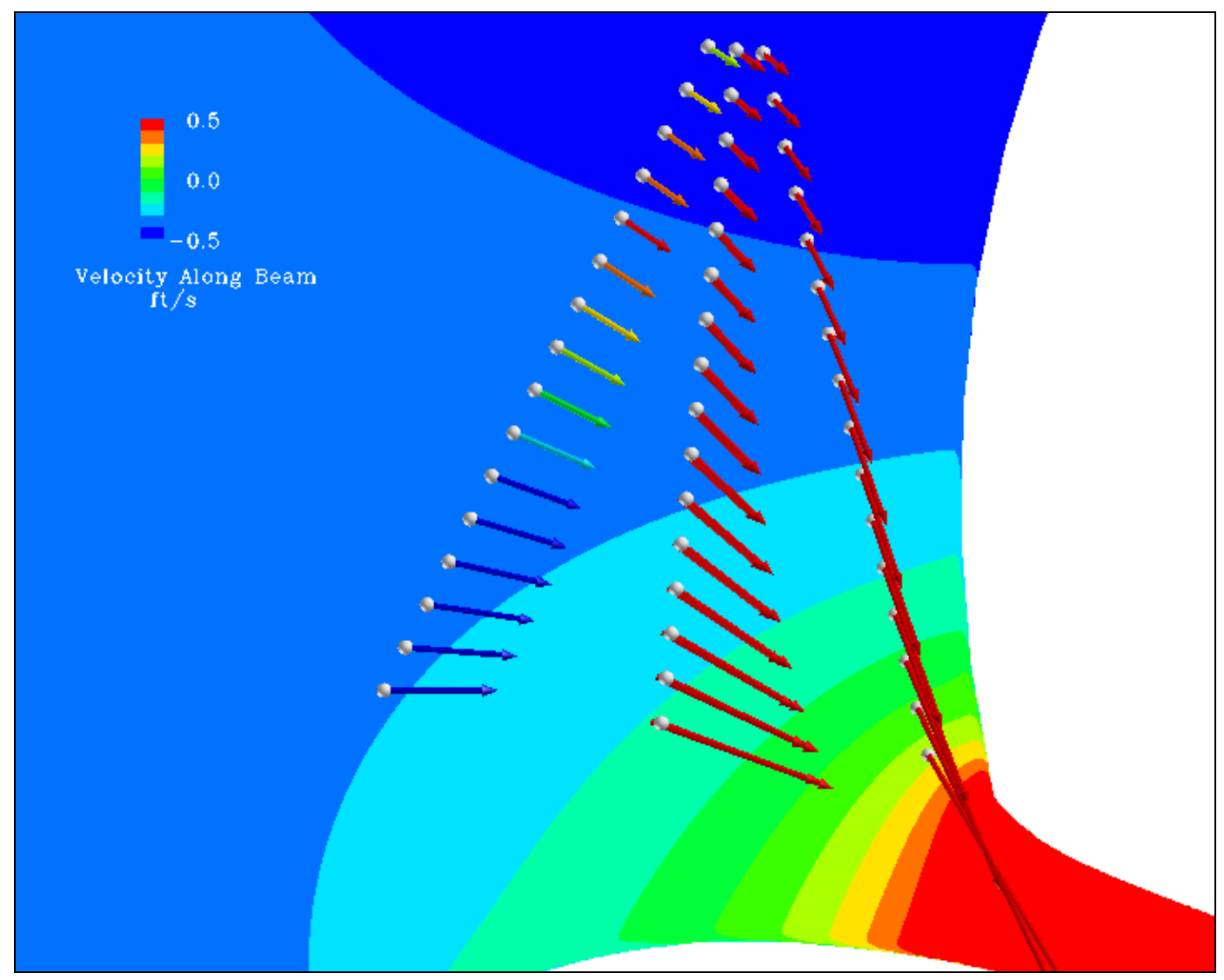

Figure 4.23. Side View of a Spill Bay with CFD Results Showing Velocity along Beams in $\mathrm{ft} / \mathrm{s}$. Gray circles represent each ADCP bin. At each circle, velocity vector arrow is the CFD computed value and has been shaded by the projected (perpendicular to beam) ADCP component. The ADCP and CFD velocity vectors are superimposed on a contour plot of the CFD data. The legend pertains to both ADCP and CFD data. 


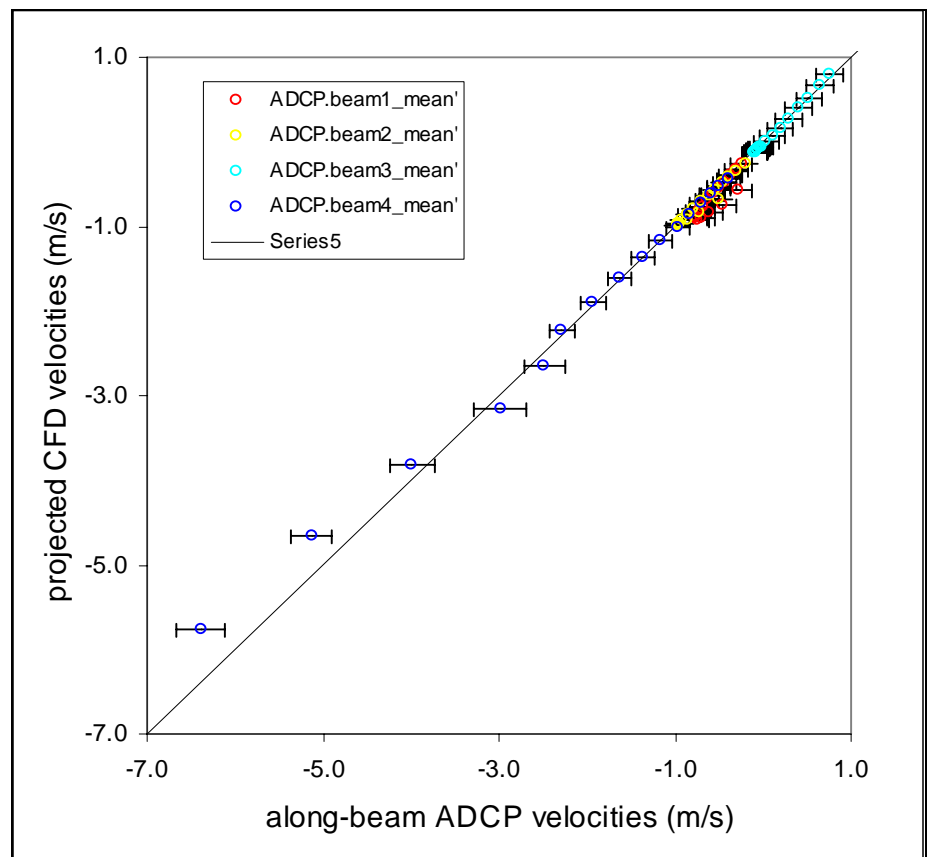

Figure 4.24. Comparison of ADCP and CFD velocity data at Spill Bay 5. Along beam velocities compared to corresponding projected ADCP velocities for each beam measured with a 600 $\mathrm{kHz}$ ADCP rotated at $7^{\circ}$. in The Dalles Dam spillway. Data were collected when the gate was open $6.5 \mathrm{ft}$. The projected velocities were those perpendicular to each beam. Mean observed values are represented by circles, and horizontal bars show the standard deviation during the sampling period (approximately 40 minutes).

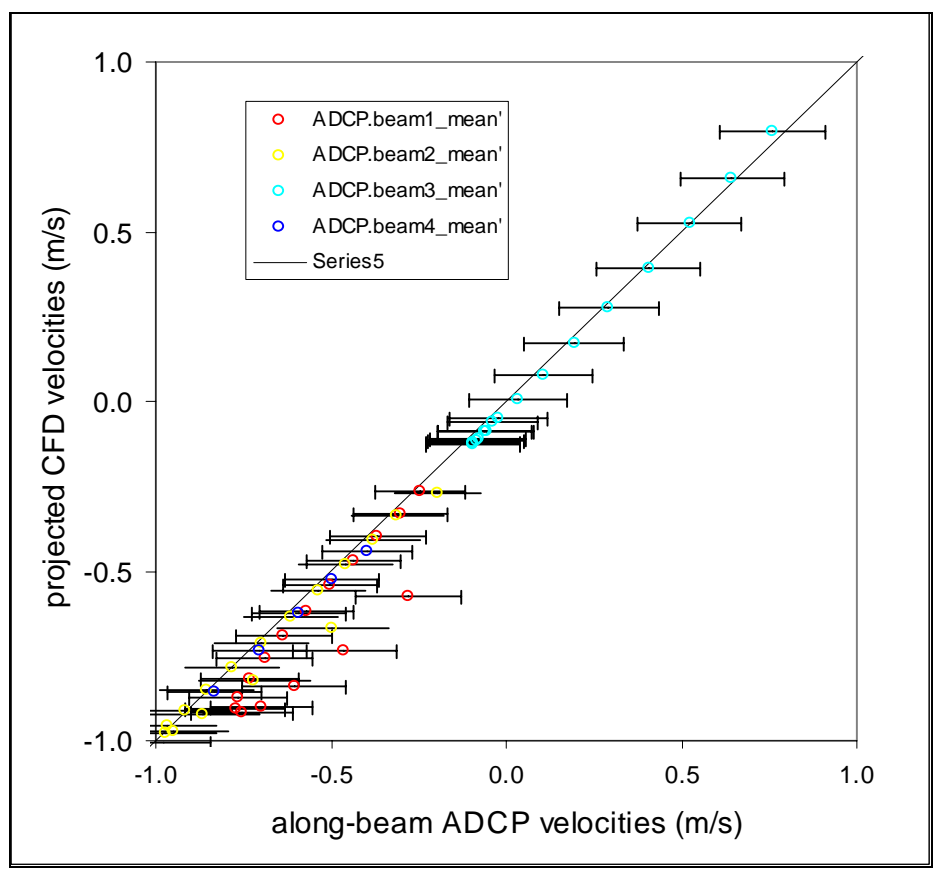

Figure 4.25. Close-up of Narrow Magnitude Velocity Range Corresponding to Figure 4.24. 


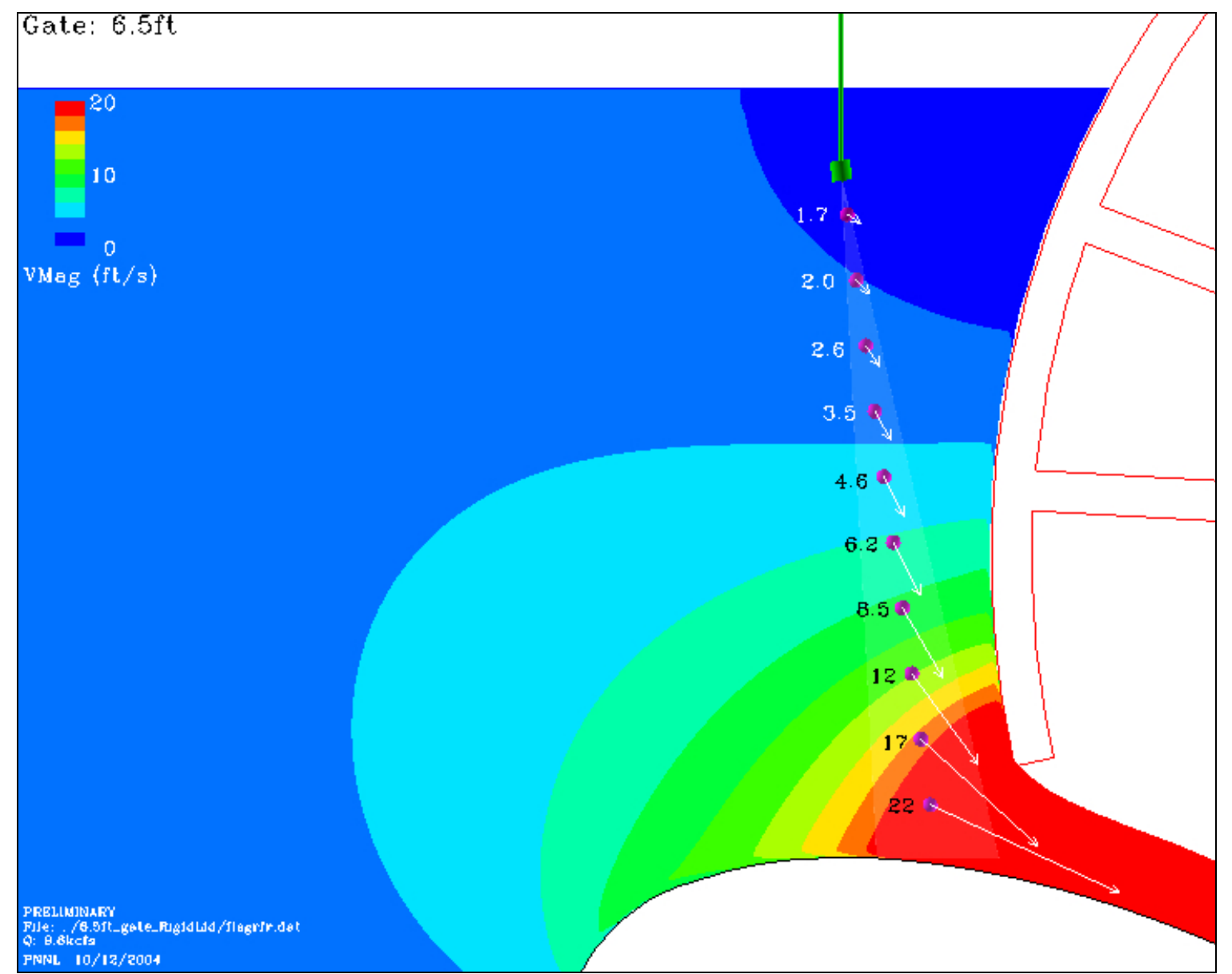

Figure 4.26. Example of Applying a CFD Model at the Spillway. The instrument depicted at the end of the pole is a split-beam hydroacoustic transducer. Velocity values were computed for various distances locations along the acoustic beam.

\subsection{Fish Passage Evaluation}

The fish passage evaluation involved data on seasonal fish passage, daily fish passage, and fish distributions.

\subsubsection{Seasonal Fish Passage}

The seasonal passage metrics were higher in spring than summer (Table 4.2). For example, fish passage efficiency was 0.91 in spring and 0.82 in summer. Spill efficiency was 0.84 and 0.78 in spring and summer, respectively. Spill effectiveness was 2.13 and 2.00 over the two respective seasons. These data compare well with those from previous years (Ploskey et al. 2001a), except for 2002 when passage efficiencies were relatively low (Johnson et al. 2003). Sluiceway efficiency for the dam as a whole was 0.071 during spring and 0.039 during summer. However, relative to the powerhouse, sluiceway efficiency was 0.442 in spring and 0.179 in summer. Sluiceway effectiveness was comparable to spillway effectiveness relative to the total project and was about four times higher than this when calculated relative to the powerhouse. 
Table 4.2. Seasonal Fish Passage Metrics for The Dalles Dam in 2004. Data are presented separately for spring and summer for the run at large. Note, the summer study period was truncated by one week (ending July 11,2004) to exclude adult shad from the analysis. Confidence intervals are at the $95 \%$ level.

\begin{tabular}{|l|c|c|}
\hline & Spring (4/19-6/5) & Summer (6/6-7/11) \\
\hline Fish Passage Efficiency & $0.910 \pm 0.003$ & $0.819 \pm 0.005$ \\
\hline Spill Efficiency & $0.839 \pm 0.006$ & $0.780 \pm 0.006$ \\
\hline Spill Effectiveness & $2.13 \pm 0.01$ & $2.00 \pm 0.05$ \\
\hline Sluice Efficiency & $0.071 \pm 0.005$ & $0.039 \pm 0.004$ \\
\hline Sluice Efficiency re: powerhouse & $0.442 \pm 0.019$ & $0.179 \pm 0.015$ \\
\hline Sluice Effectiveness & $3.25 \pm 0.22$ & $1.65 \pm 0.16$ \\
\hline Sluice Effectiveness re: powerhouse & $12.19 \pm 0.59$ & $4.58 \pm 0.46$ \\
\hline
\end{tabular}

\subsubsection{Daily Fish Passage}

\section{Run Timing}

A comparison of the peaks in the hydroacoustic and SMP passage indices showed a reasonable match (Figure 4.27). The hydroacoustic peaks early in the study period were likely from hatchery releases in the Deschutes River drainage, and those late in the study period were probably from adult shad. Neither of these sources would show up in the SMP index from John Day Dam. The timing of the passage peaks in late May and late June corresponded fairly well but SMP and hydroacoustic peaks in June and July did not correspond for unknown reasons.

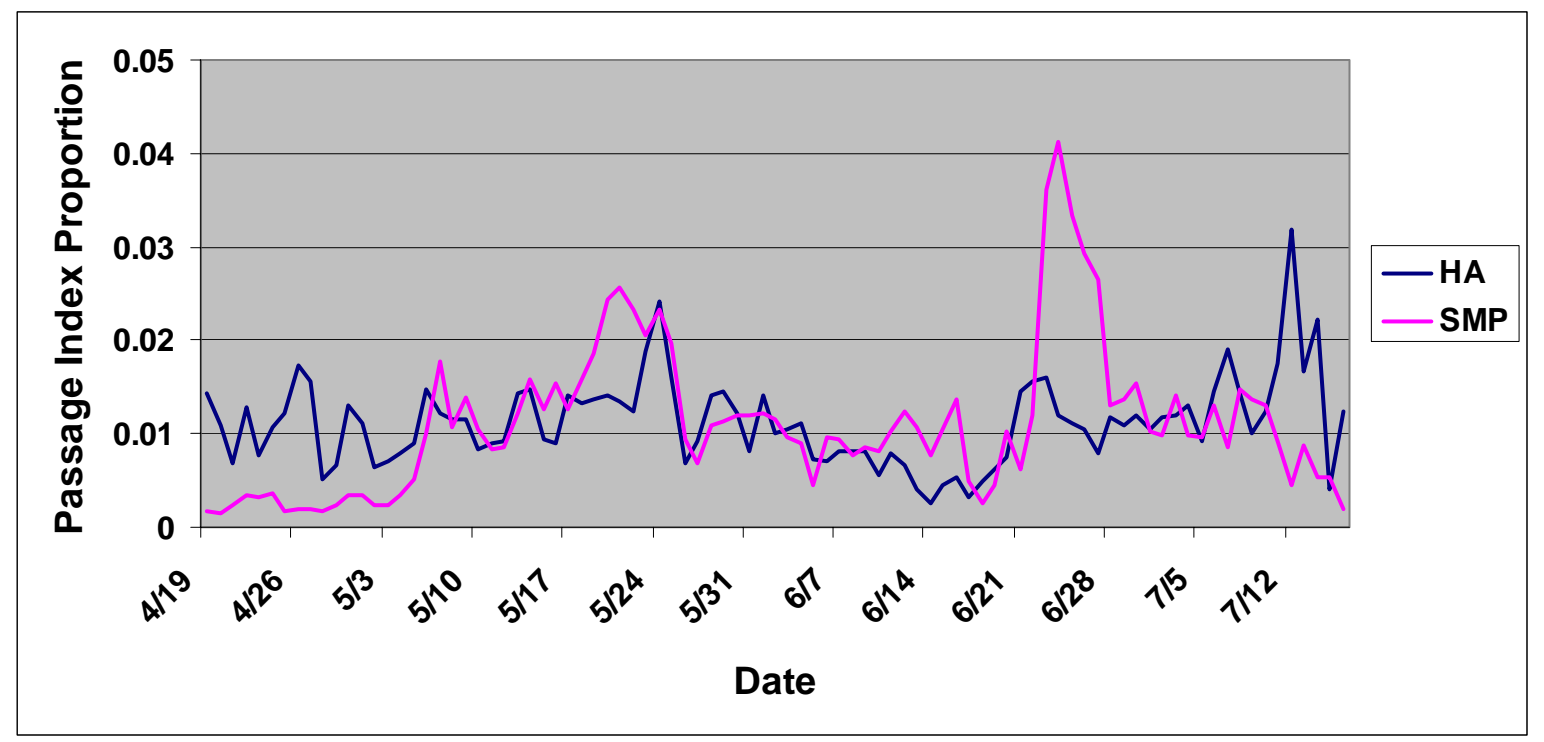

Figure 4.27. Fish Passage Indices for The Dalles Dam in 2004. Data are expressed as daily proportion of the total for the April 19 to July 17 study period. The hydroacoustic index is for the run at large as sampled at TDA. The Smolt Monitoring Program index is for all species combined as sampled at John Day Dam. 


\section{Passage Efficiency}

Passage efficiency is the proportion of fish passing a particular route out of total project or total powerhouse passage. Spill passage drove total project fish passage efficiency at The Dalles Dam (Figure 4.28). Sluiceway passage provided an important incremental benefit to non-turbine passage, but most fish passed over the spillway given the $40 \%$ spill operation. However, at the powerhouse, sluiceway passage is the only non-turbine route. Daily sluiceway efficiency was highly variable ranging from 0.0 to 0.8 (Figure 4.28). Passage efficiencies dipped in late May and early June (Figure 4.28).

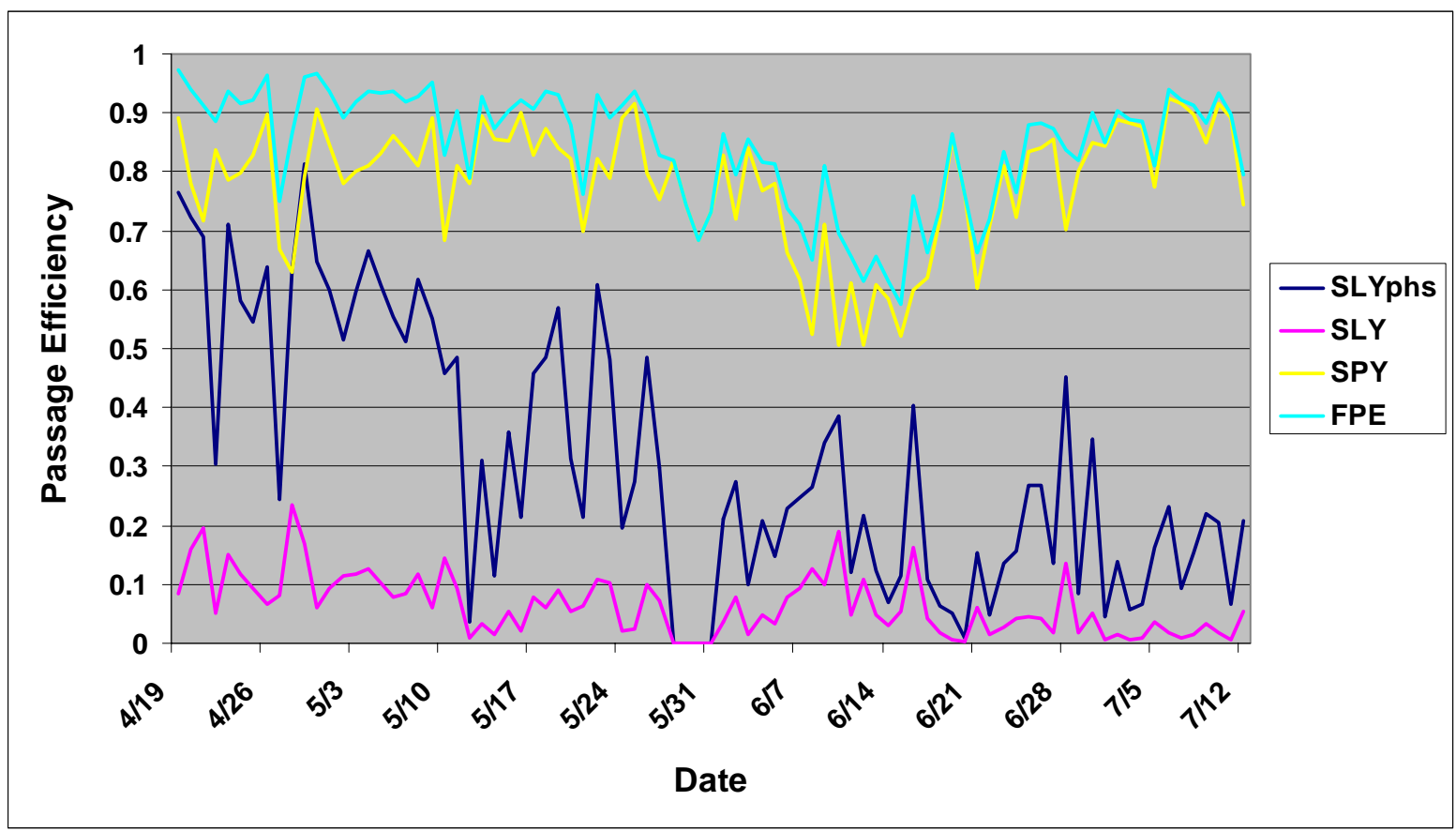

Figure 4.28. Daily Passage Efficiencies at The Dalles Dam in 2004. Data are expressed as proportions as follows: SLYphs is sluice passage relative to turbine plus sluice passage at the powerhouse; SLY is sluice passage relative to total project passage; SPY is spill passage relative to total project passage; and FPE is sluice plus spill passage relative to total project passage.

\section{Passage Effectiveness}

Passage effectiveness is the ratio of the proportion of fish to the proportion of flow for a particular passage route(s). Daily fish passage effectiveness for the project as a whole (FPS) and spillway effectiveness (SPS) ranged between 1.27 and 3.45 (Figure 4.29). As with passage efficiency, total project fish passage effectiveness was dominated by spillway effectiveness. Daily sluiceway effectiveness relative to the project as a whole (SLS) was from 0 to 9.98 (Figure 4.29). However, sluiceway effectiveness relative to the powerhouse (SLSphs) ranged from 0 to 23.93. Sluiceway effectiveness was variable from day to day with a declining trend during the study period (Figure 4.29). 


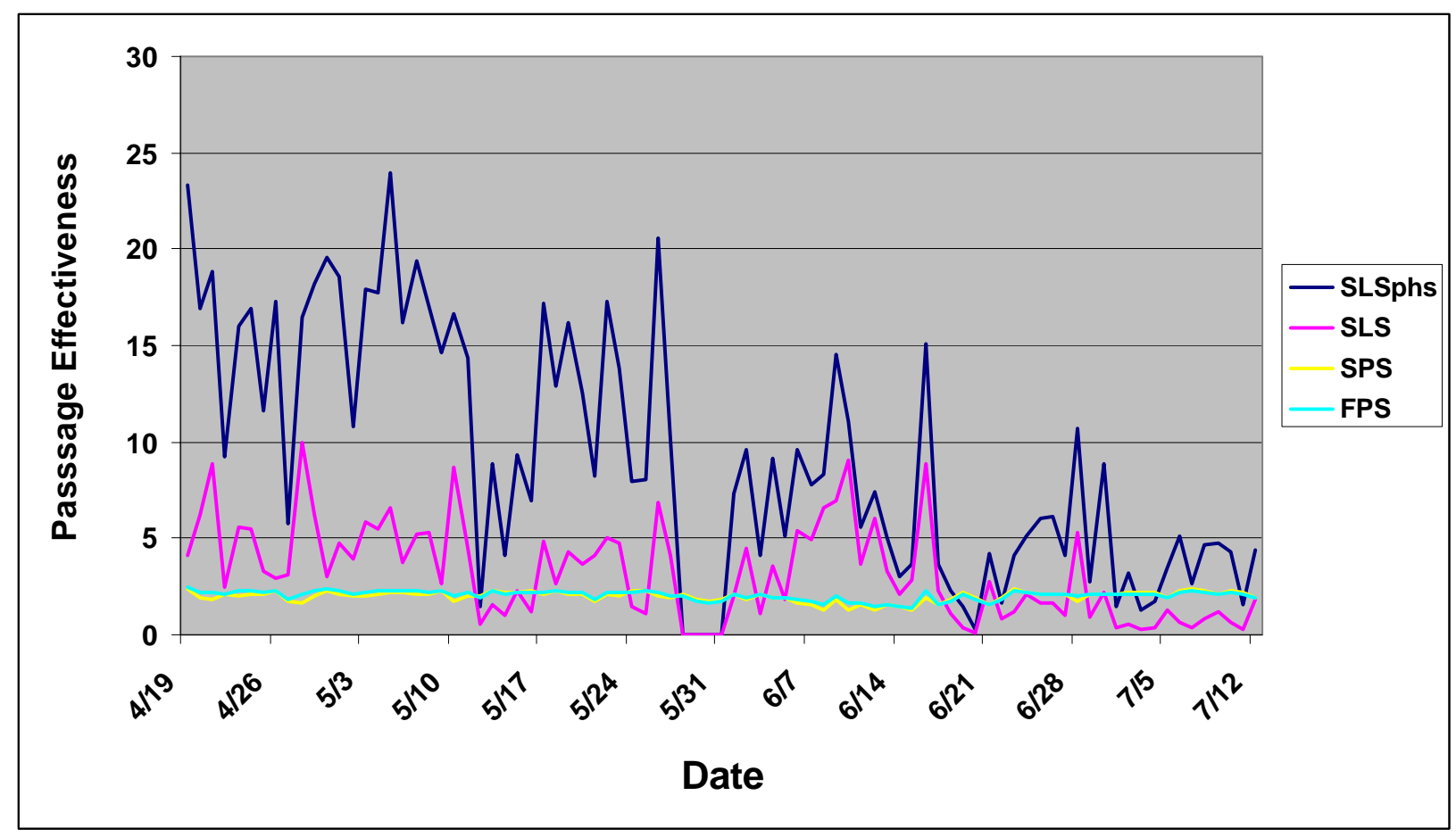

Figure 4.29. Daily Passage Effectiveness at The Dalles Dam in 2004. Data are expressed as ratios of proportions of fish to flow as follows: SLSphs is sluice relative to turbine plus sluice at the powerhouse; SLS is sluice relative to total project; SPS is spill relative to total project; and FPS is sluice plus spill relative to total project.

\subsubsection{Hourly Fish Passage}

We examined hourly passage data for spill efficiency versus spill rate and spill efficiency versus spill proportion (proportion of water spilled out of total project discharge). These data are exploratory.

\section{Spill Efficiency versus Spill Rate}

Hourly data for spill efficiency versus spill rate are shown in Figure 4.30. Hourly values of spill efficiency were high at all spill rates sampled ( 30,000 to 150,000 cfs). At spill rates in the range $\sim 70,000$ to $110,000 \mathrm{cfs}$, there were moderate and low values for spill efficiency. Most of the observations were in the 70,000-110,000 cfs range, so moderate and low values might be expected.

\section{Spill Efficiency versus Spill Proportion}

Hourly data for spill efficiency versus spill rate are shown in Figure 4.31. Hourly values of spill efficiency were high at all spill proportions sampled (0.25 to 0.65$)$. Since the spill operation was mandated at $40 \%$ of total project discharge, most of the values for spill proportion are at or near 0.40 . 


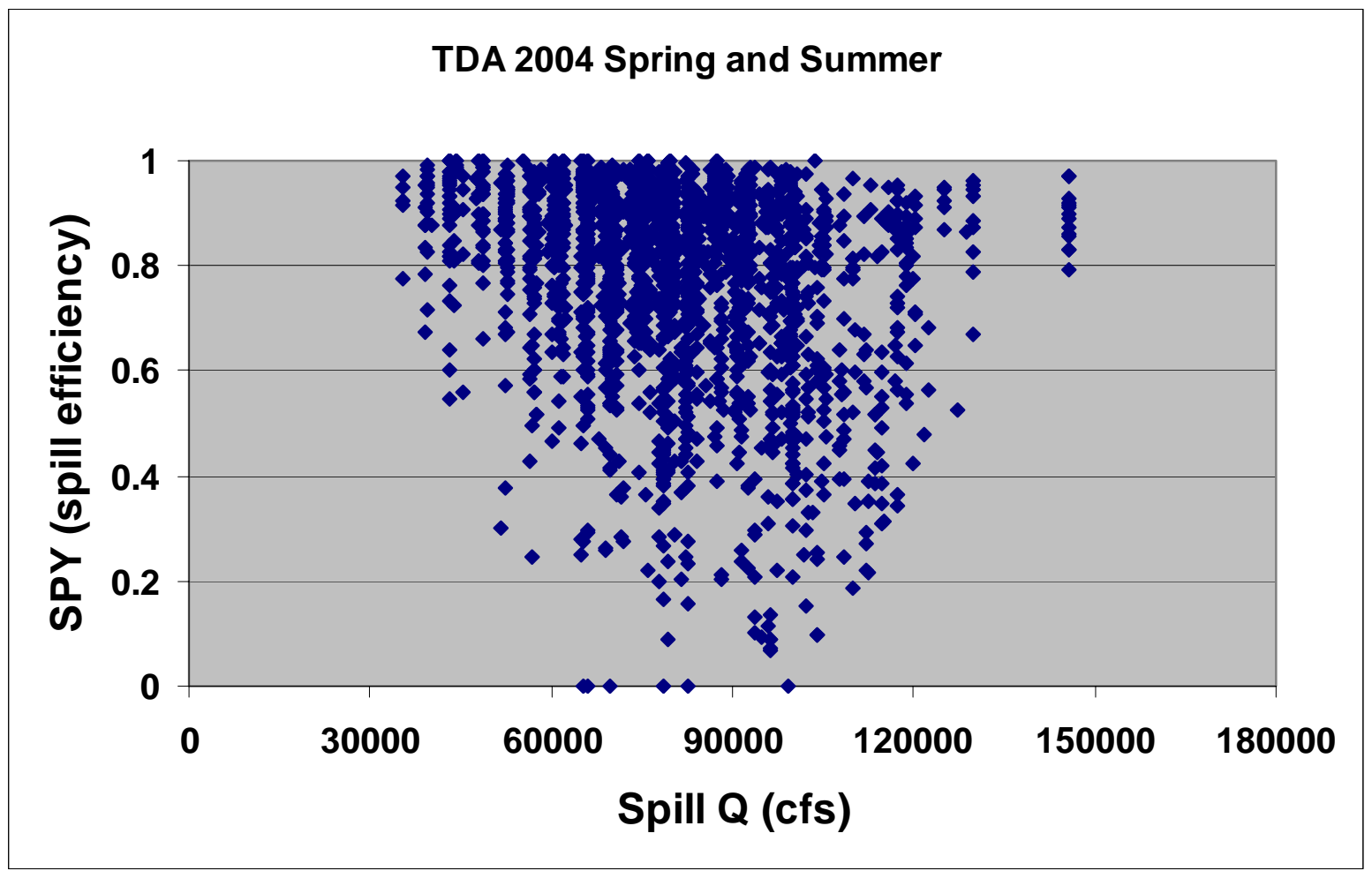

Figure 4.30. Hourly Spill Efficiency vs. Spill Discharge (cfs) for Spring and Summer Combined.

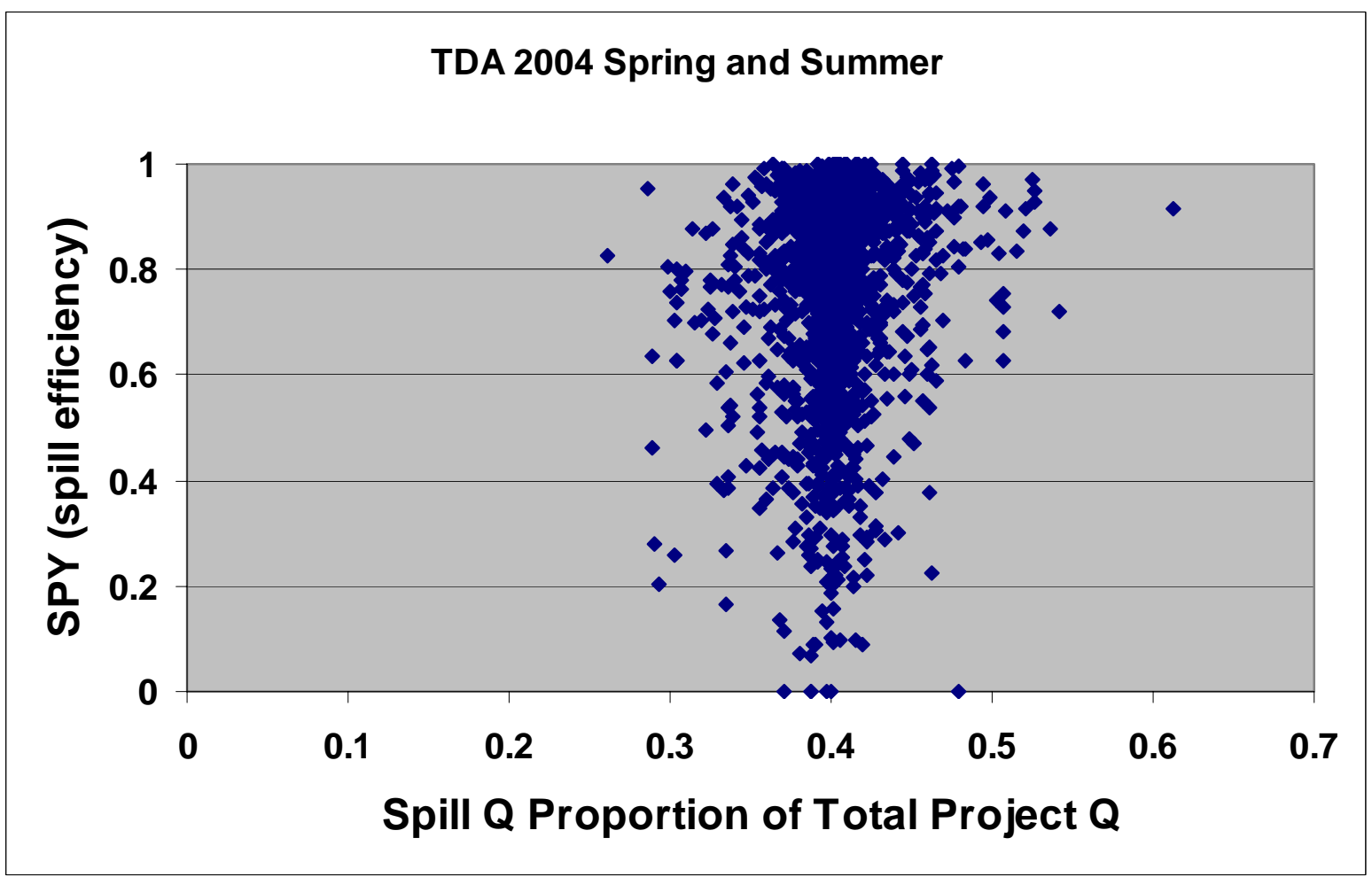

Figure 4.31. Hourly Spill Efficiency vs. Spill Discharge Proportion for Spring and Summer Combined. 


\subsubsection{Fish Distributions}

Three types of fish distribution data were analyzed from the fixed location hydroacoustic data set: vertical, horizontal, and diel. The distribution data are presented individually for the powerhouse turbine intakes, spillway, and sluiceway for spring and summer study periods separately.

\section{Vertical Distribution}

The vertical distribution of fish at sampling locations at the powerhouse turbine intakes and the spillway was deeper during summer than spring (Figure 4.32). This is typical for spring vs. summer emigrants (Ploskey et al. 2001a). At the powerhouse intakes, fish were deeper during night than day in spring, whereas the opposite was true for summer (Figure 4.32). At the spillway, fish were deeper during day than night in both spring and summer (Figure 4.32).
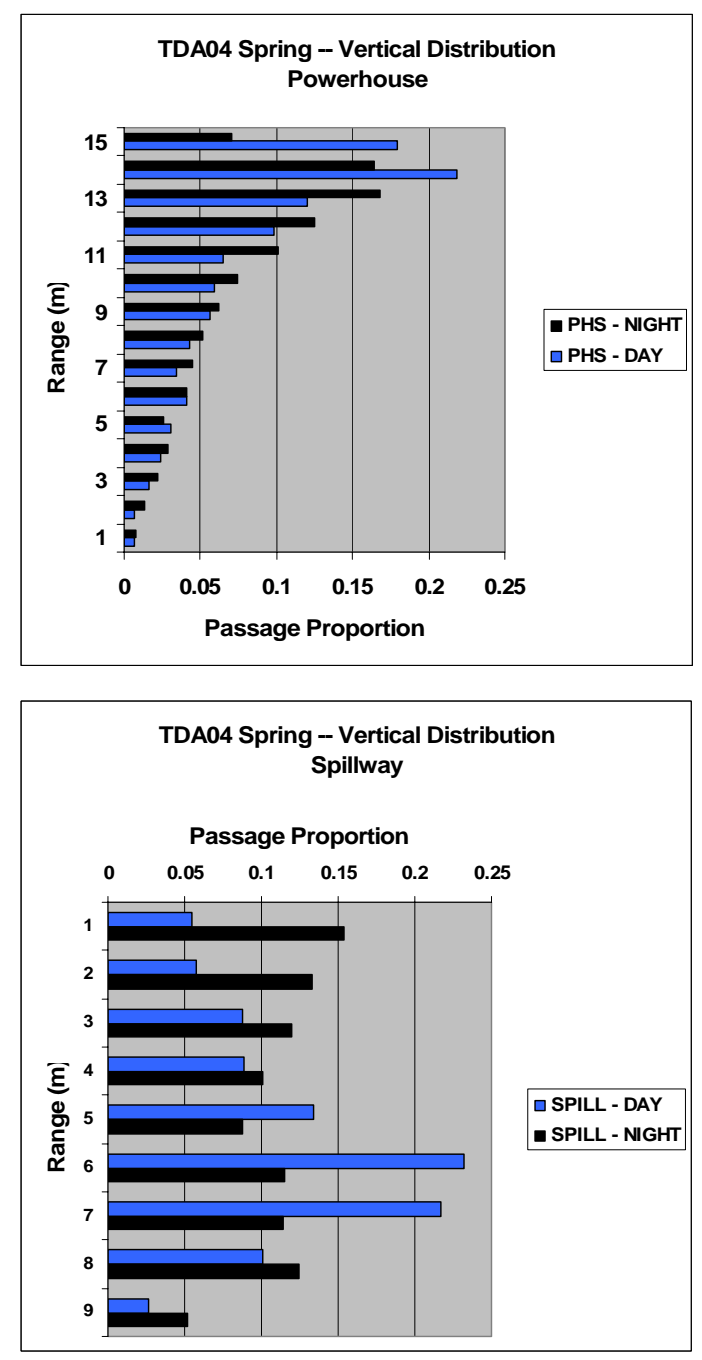
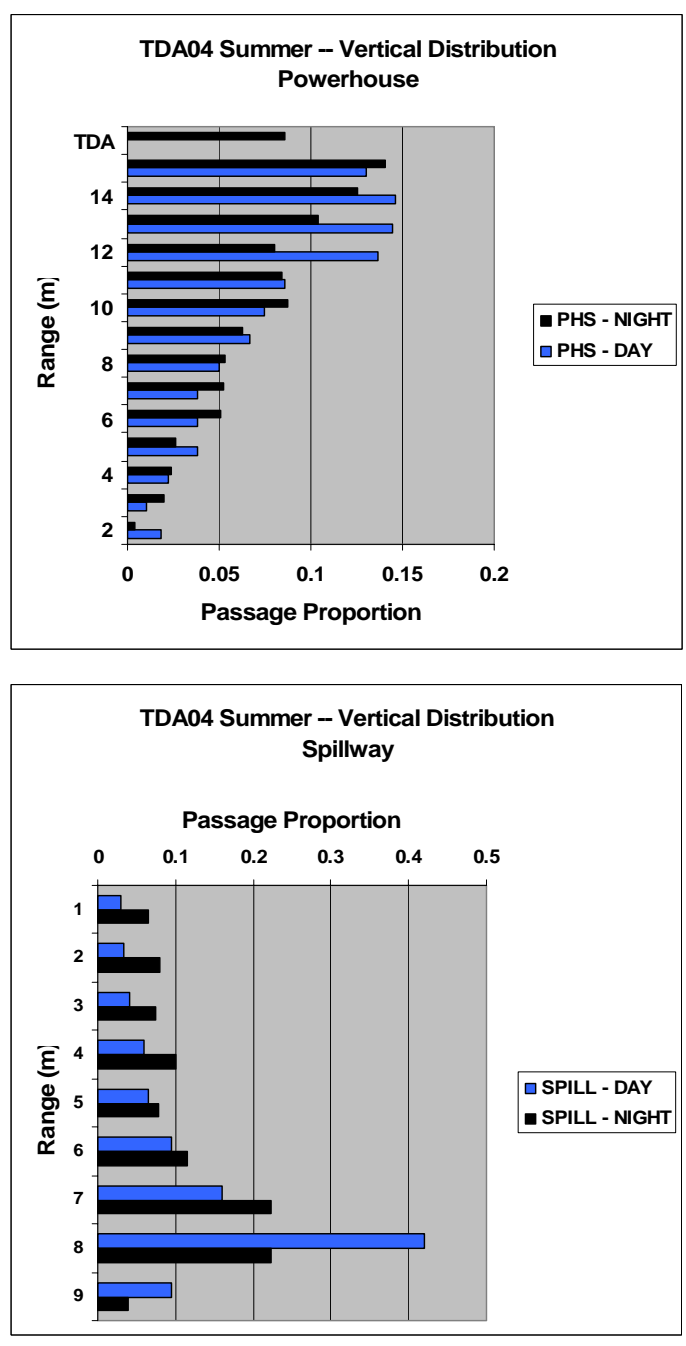

Figure 4.32. Vertical Distributions at the Powerhouse Turbine Intakes and Spillway for Day and Night in Spring and Summer in 2004. Data are presented as proportions of total passage in 1-m-range bins from the transducer to the ceiling and ogee for the powerhouse turbine intakes and spillway, respectively. For the powerhouse data (upper row of figures), the turbine intake ceiling is at the top of each figure. For the spillway data (lower row of figures), the ogee is at the bottom of each figure. 


\section{Horizontal Distribution}

At the powerhouse, the horizontal distribution of fish passage was highest at SL 1 and MU 8 during spring (Figure 4.33, top left). During summer, passage at the powerhouse was fairly uniform, with highest passage at MU 8 (Figure 4.33, top right). There was no passage at MU 3, 4, 6, and 7 because, as mentioned above, these units were off-line the entire study. The horizontal distribution was not skewed to the east during summer, as observed in previous studies (e.g., Johnson et al. 2003).

At the spillway, the horizontal distribution of fish passage was highest at Bay 6 and Bay 2 during spring (Figure 4.33, bottom left). During summer, passage at the spillway was fairly uniform, with highest passage at Bays 2 and 3 (Figure 4.33, bottom right). Bays 7-10 were not typically opened, but when they were, fish passed there, especially in Bay 7 (Figure 4.33).
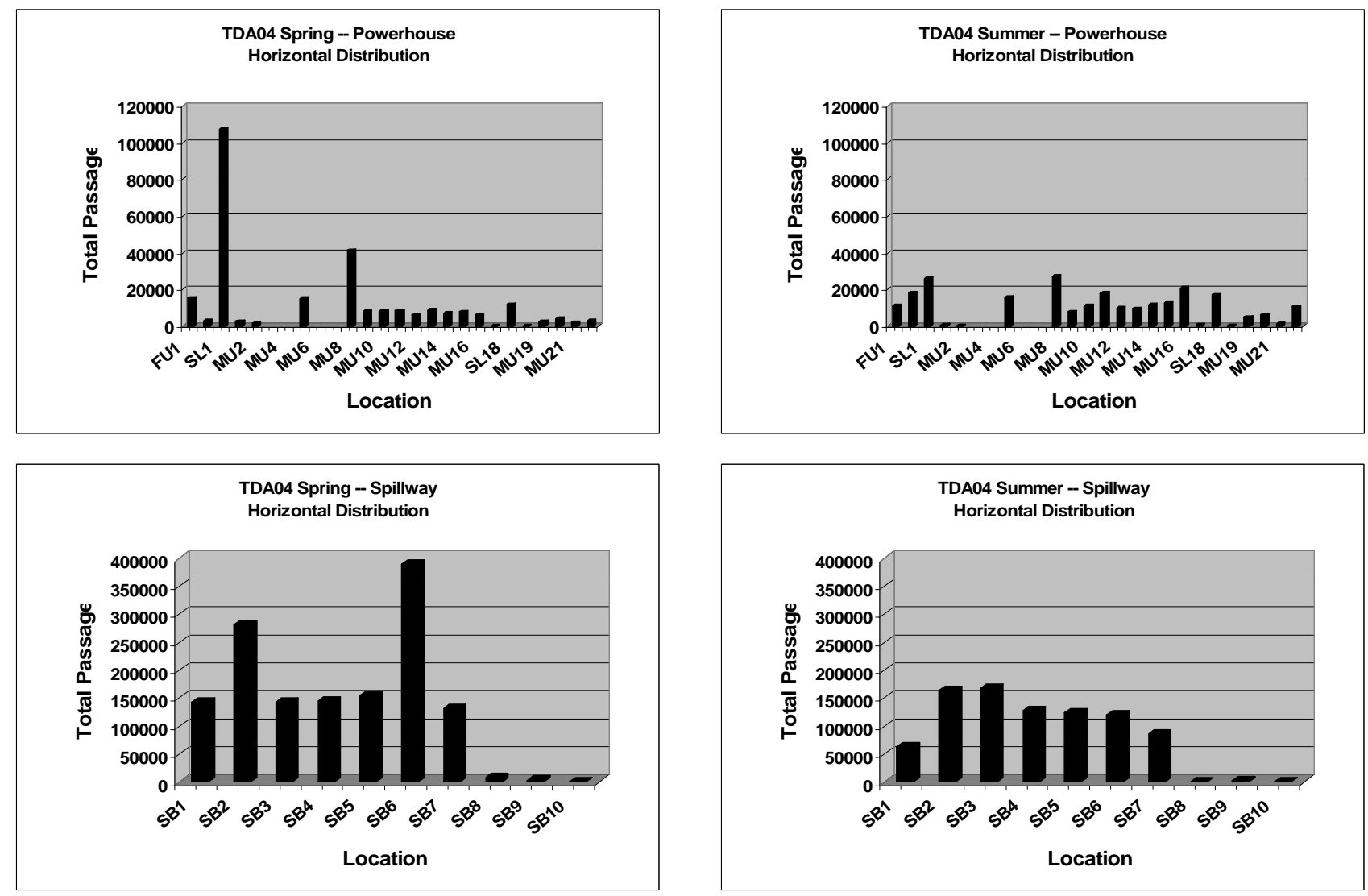

Figure 4.33. Horizontal Distributions at the Powerhouse and Spillway in Spring and Summer in 2004. The powerhouse data include passage at the sluice entrances (SL 1 and 18), the fish units, and the main units. Looking left to right at the powerhouse data (upper row of figures) corresponds to looking from Fish Unit 1 to Main Unit 22. Looking left to right at the spillway data (lower row of figures) corresponds to looking from Spill Bay 1 to Spill Bay 10. 


\section{Diel Distribution}

The diel distribution of passage was much more variable during summer than spring (Figure 4.34). During spring, passage at the powerhouse turbine intakes peaked at dusk while sluiceway and spillway passage was relatively uniform (Figure 4.34). During summer, powerhouse turbine intake passage was highest during 2300-2400 h, sluiceway passage peaked during daytime, and spillway passage was greatest at dawn (Figure 4.34).
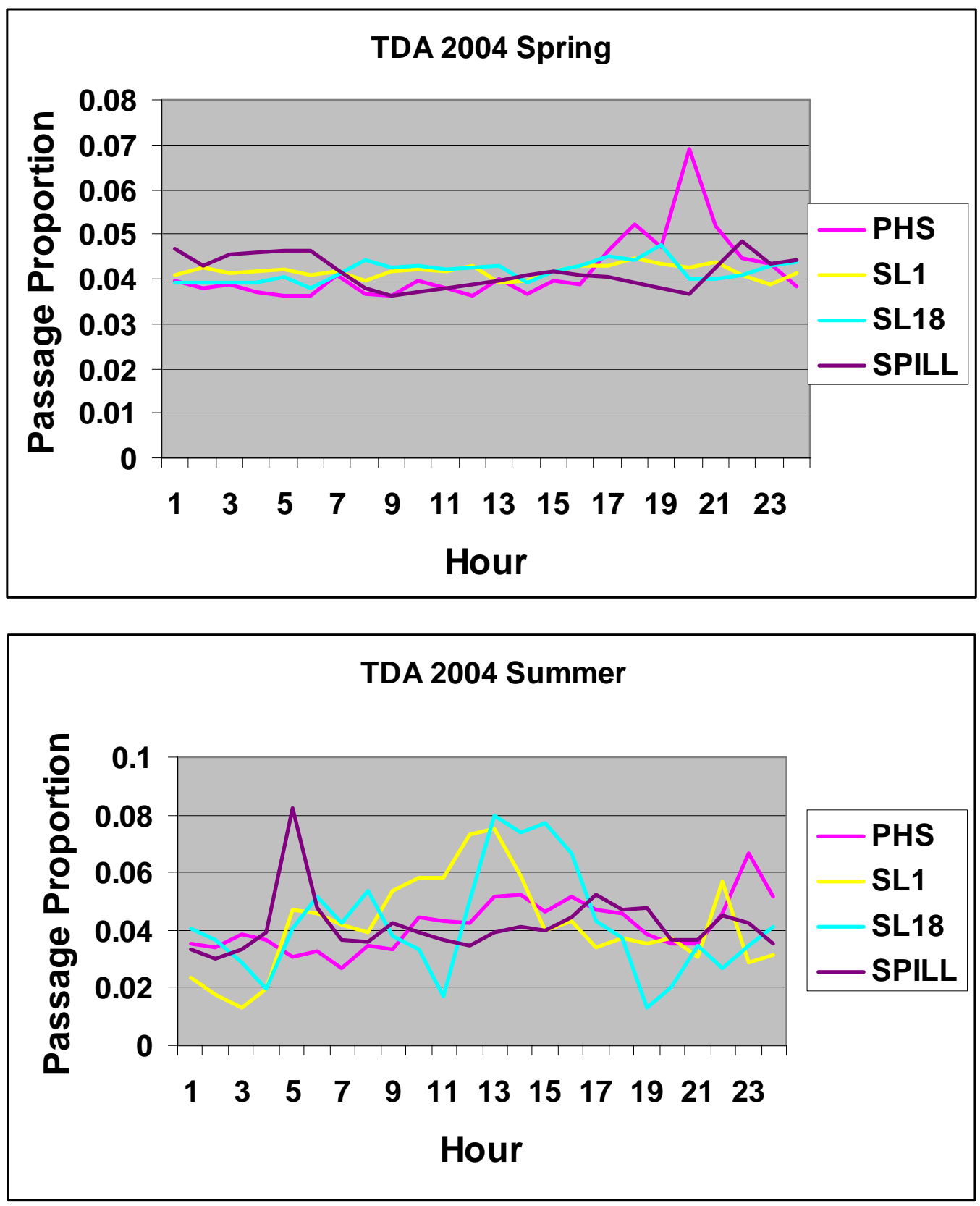

Figure 4.34. Diel Distributions at the Powerhouse Turbine Intakes, Spillway, Sluice 1, and Sluice 18 in Spring (top figure) and Summer (bottom figure) in 2004. 


\subsubsection{Fish Passage Distribution at Spill Bay 5}

Fish passage data from the three split-beam transducers deployed at Spill Bay 5 were analyzed to describe the combined vertical and horizontal distribution of passage (Figure 4.35). During the day in spring and summer, passage was relatively high in a band across the entire bay, although this layer was at El. 129-137 ft in spring and El. 122-127 ft in summer. Passage distribution varied between day and night and between spring and summer.

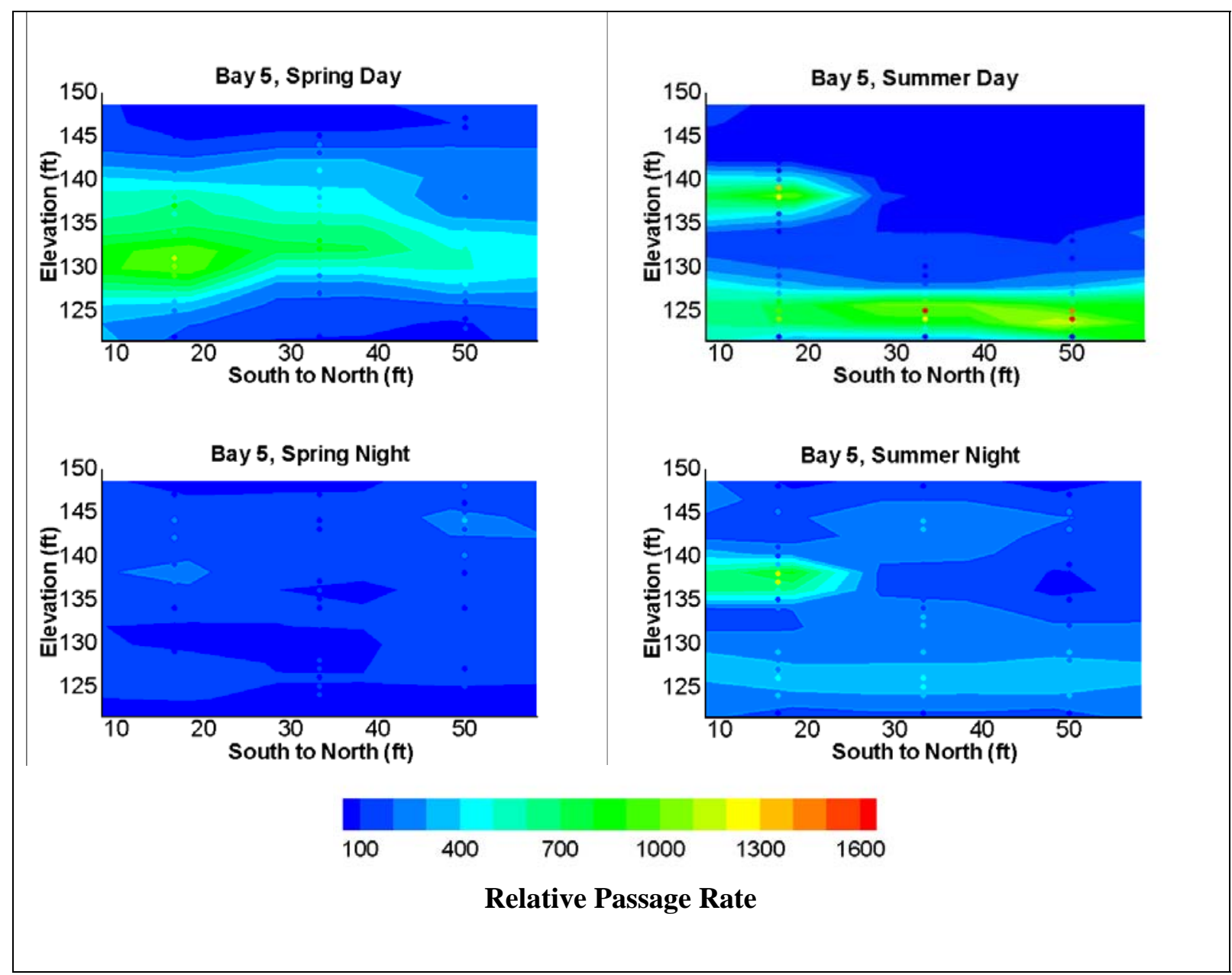

Figure 4.35. Front View of Bay 5 Showing Contours of Relative Fish Passage Rates for Spring and Summer 2004, Day and Night. The passage rate is relative because it has been normalized spatially but not extrapolated temporally. Sample points shown (see three columns of points in each figure) are for the three split beam transducers deployed at Bay 5. The data were interpolated with resolution of $1 \mathrm{ft}$ vertically and $16.67 \mathrm{ft}$ horizontally. The $\mathrm{X}$ - and $\mathrm{Y}$-axes have the same scale; the bay is $50 \mathrm{ft}$ wide and $37 \mathrm{ft}$ high. The ogee is at El. $121 \mathrm{ft}$ and the mean water surface is at El. $158 \mathrm{ft}$. 


\subsection{Sluiceway Evaluation}

The objectives for the sluiceway evaluation for The Dalles Dam in 2004 included 1) analysis of the effect of skimmer gate operations on sluiceway passage and 2) integration of sluiceway nearfield fish movements and sluiceway passage data with hydraulic data. The objective stated in Section 1.1 regarding recommendations for long-term smolt protection measures will be addressed in Section 6 .

The format for the results of the sluiceway evaluation differs from that for previous sections. For each of the two main objectives of the sluiceway evaluation, we asked key operational and fisheries resource management questions regarding the TDA sluiceway and then responded with pertinent results from this study. This format emphasizes the management applications of the data.

\subsubsection{Analysis of Sluiceway Operations}

Did opening sluice gates at the east end of the dam (SL 18) in conjunction with those at the west end (SL1) increase sluiceway passage over that for the west (SL 1) alone?

Yes, opening east end gates did increase total sluice passage over that for the west gates alone (Table 4.3). For the study as a whole, total sluice passage was $11 \%$ higher in spring and $65 \%$ higher in summer with the east gates (SL 18) open than with the west gates (SL 1) alone. For the period when east gates and west gates were opened, total sluice passage increased by $21 \%$ in spring and by $221 \%$ in summer.

The results, however, were not statistically significant except for one case. ANOVAs for day and night separately revealed no significant difference in total sluice passage between the two sluice treatments in spring $(\mathrm{P}>0.1)$ and summer $(\mathrm{P}>0.1)$; the exception was summer-day $(\mathrm{P}<0.05)$.

Total sluice passage for the West treatment was greater than that for the West+East treatment in 17 of 24 blocks in spring (Figure 4.36 and 16 of 18 blocks in summer (Figure 4.37). Having the east end gates open put total sluice passage "over the top", i.e., made the total for West+East greater than total sluice passage for West in a particular block, in 3 of 24 blocks in spring (Figure 4.33) and 8 of 18 blocks in summer (Figure 4.37). Overall, in spring and summer, passage at the east end sluice (SL18) out of total sluice passage was $10 \%$ and $40 \%$, respectively (Table 4.3 ). In sum, opening east end sluice gates resulted in increased total sluice passage over operating the west gates alone, but the results generally were not statistically significant.

Table 4.3. Analysis of the Benefits of East End Sluice Gate Operation by Season at The Dalles Dam in 2004. SL 18 benefit is expressed as the ratio of a total (SL 1+SL 18) to SL 1.

\begin{tabular}{|c|c|c|c|c|}
\hline & \multicolumn{2}{|c|}{ Spring } & \multicolumn{2}{|c|}{ Summer } \\
\hline & SL1 & SL18 & SL1 & SL18 \\
\hline Total W & 48639 & 0 & 12070 & 0 \\
\hline Total W+E & 57574 & 11839 & 14071 & 17093 \\
\hline Total & 106213 & 11839 & 26141 & 17093 \\
\hline Grand Total Sluice & \multicolumn{2}{|c|}{118052} & \multicolumn{2}{|c|}{43234} \\
\hline SL18 benefit & \multicolumn{2}{|c|}{1.11} & \multicolumn{2}{|c|}{1.65} \\
\hline Total Sluice W+E & \multicolumn{2}{|c|}{69413} & \multicolumn{2}{|c|}{31164} \\
\hline SL18 benefit & \multicolumn{2}{|c|}{1.21} & \multicolumn{2}{|c|}{2.21} \\
\hline
\end{tabular}




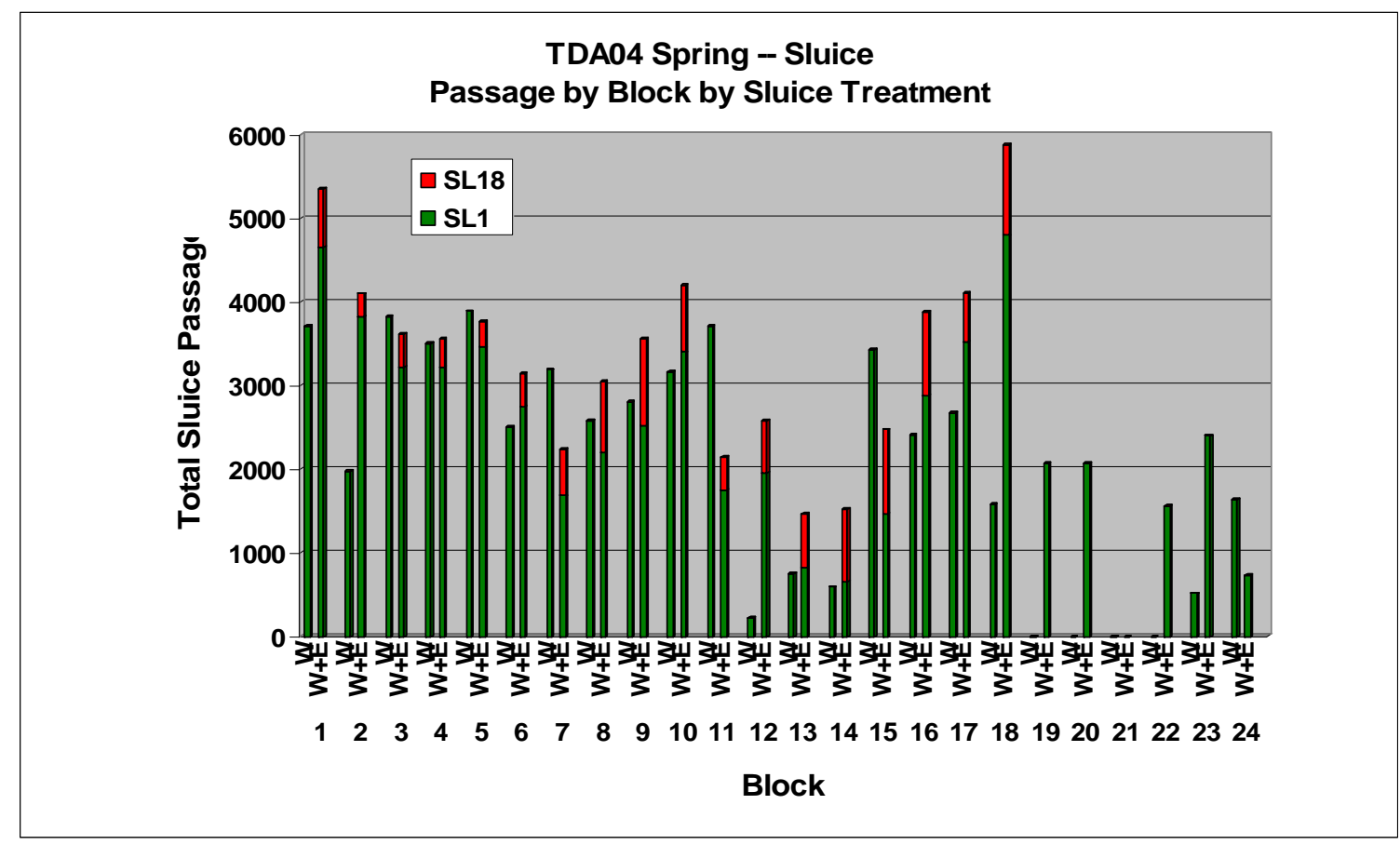

Figure 4.36. Total Sluiceway Passage by Block by Treatment (West and West+East) for The Dalles Dam in Spring 2004.

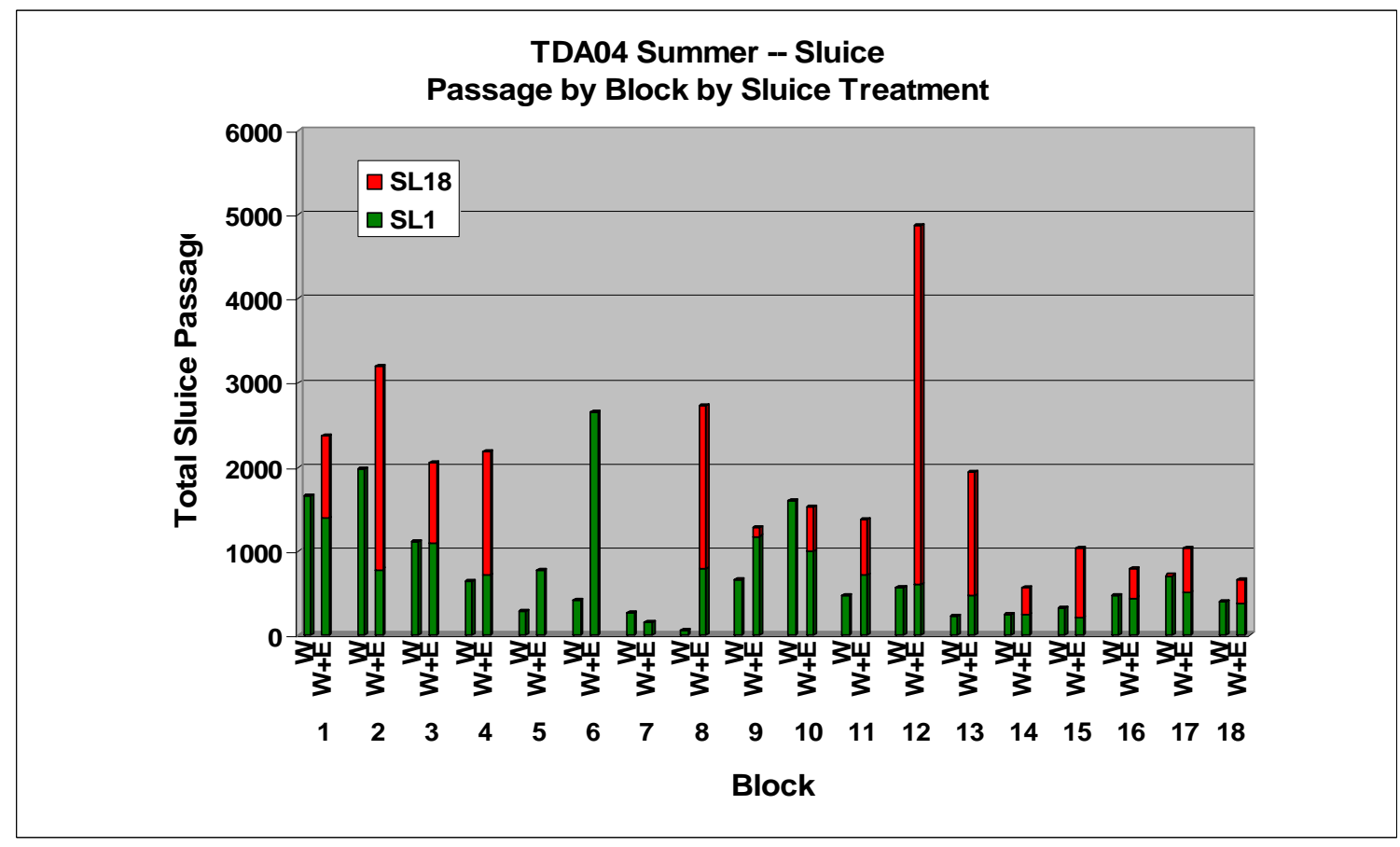

Figure 4.37. Total Sluiceway Passage by Block by Treatment (West and West+East) for The Dalles Dam in Summer 2004. 
Did opening sluice gates at the east end of the dam (SL 18) in conjunction with those at the west end (SL 1) increase sluiceway efficiency (re: powerhouse) over that for the west alone?

Yes, opening the east end sluice contributed 4 percentage points of the total $44 \%$ sluice efficiency at the powerhouse in spring and 7 percentage points of the total 17\% SLY (re: powerhouse) in summer (Table 4.4). In both day and night periods in spring and summer, sluiceway efficiency (re: powerhouse) was significantly $(\mathrm{P}<0.05)$ higher with the West+East treatment than the West only treatment.

Table 4.4. Sluiceway Efficiencies Relative to Total Powerhouse Passage for West (SL 1), East (SL 18), and Total (SLY) Sluice Routes by Treatment and Season at The Dalles Dam in 2004.

\begin{tabular}{|l|ccc|ccc|}
\hline & \multicolumn{3}{|c|}{ Spring } & \multicolumn{3}{c|}{ Summer } \\
\hline & SLY 1 & SLY 18 & SLY re:phs & SLY 1 & SLY 18 & SLY re:phs \\
\hline Total W & 0.37 & 0.00 & 0.37 & 0.10 & 0.00 & 0.10 \\
Total W+E & 0.43 & 0.09 & 0.52 & 0.11 & 0.13 & 0.23 \\
Total & 0.40 & 0.04 & 0.44 & 0.11 & 0.07 & 0.17 \\
\hline
\end{tabular}

Did opening sluice gates at the east end of the dam (SL 18) reduce turbine passage at the eastern part of the dam (MU 17 to $M U$ 22)?

Yes, opening sluice gates at the east end of the dam (SL 18) reduced turbine passage at the eastern part of the dam (MU 17 to MU 22) in 3 of 4 combinations of season and day and night, but results were not statistically significant $(\mathrm{P}>0.10)$ for pooled data (Table 4.5$)$.

Table 4.5. East Turbine Passage (MU 17-22) by Day/Night, Treatment, and Season at The Dalles Dam in 2004. Data are the average across the experimental blocks of hourly passage rates for MU 17-22 combined.

\begin{tabular}{|cccc|}
\hline Period & Treatment & Spring & Summer \\
\hline Day & W & 144 & 373 \\
& W+E & 125 & 326 \\
\hline Night & W & 118 & 213 \\
& W+E & 97 & 274 \\
\hline
\end{tabular}

Did opening the east end sluice gates (SL 18) pass fish that otherwise likely would have passed at the west end sluice gates (SL 1)?

No, the horizontal distribution data indicate passage into the west sluice gates (SL1) generally was not lower during the West+East treatment than during the West only treatment (Figures 4.38 and 4.39). If west sluice gate passage had been lower, it would have indicated that opening the east end gates would not be a benefit because the fish that went in the east sluice may have used the west sluice. 

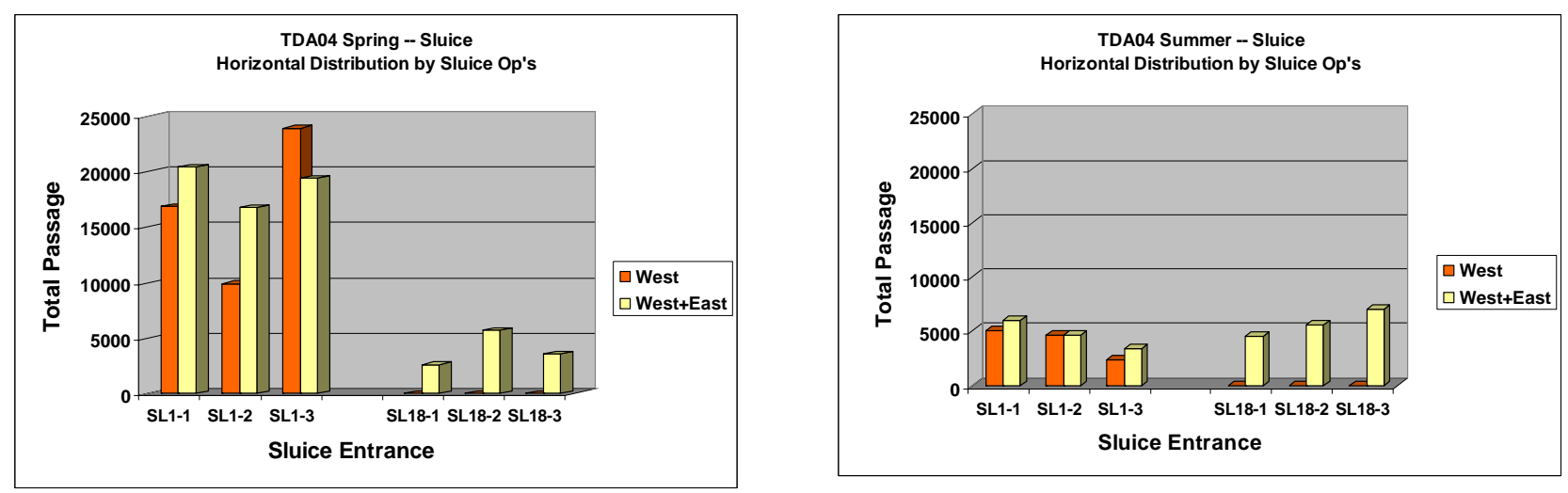

Figure 4.38. Horizontal Distribution of Passage into Open Sluice Gates by Sluice Treatment (West vs West+East) for Spring (left) and Summer (right) at The Dalles Dam in 2004.
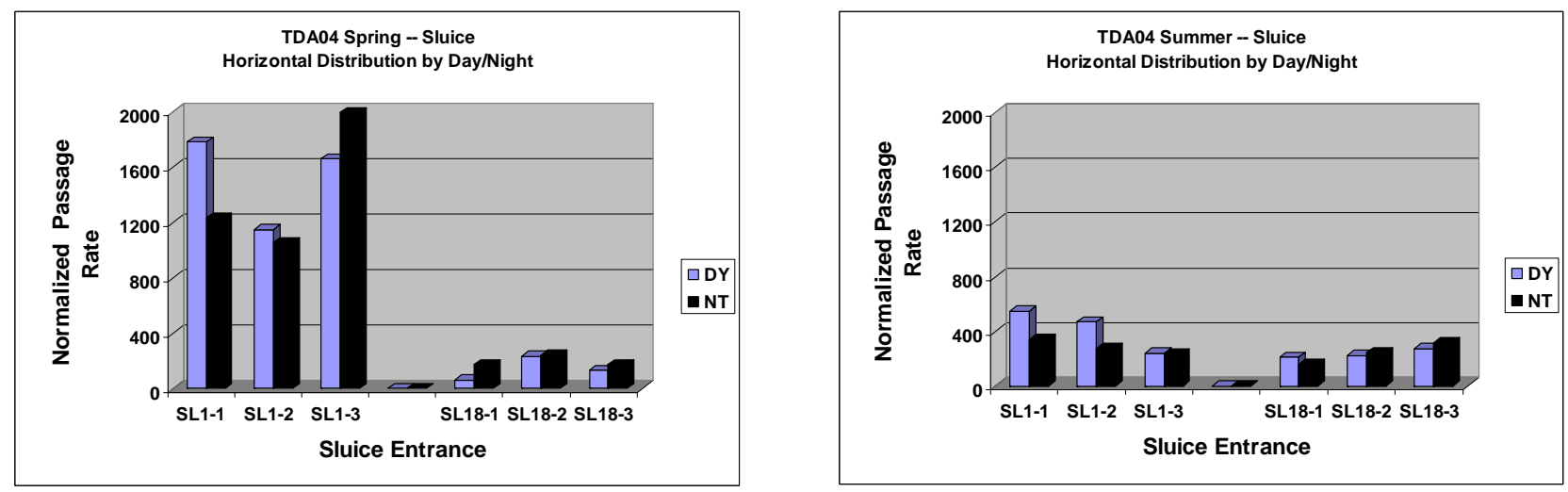

Figure 4.39. Horizontal Distribution of Passage into Open Sluice Gates by Day/Night for Spring (left) and Summer (right) at The Dalles Dam in 2004.

\subsubsection{Integration of Fish Movement and Passage Data with Hydraulic Data}

This section includes data on juvenile salmonid movements in the nearfield $(<30 \mathrm{ft})$ of the sluiceway entrances at SL 1 and SL 18 that we collected using the acoustic camera, as well as fish passage data from fixed hydroacoustic systems. The fish data were integrated with hydraulic data on water velocities in the nearfield from CFD model runs and turbine and sluice discharge data from records of project operations to answer several research questions.

What was the extent of the zone of influence of the sluiceway as revealed by juvenile salmonid movement patterns?

The sluiceway zone of influence is the region immediately upstream of a sluice entrance where juvenile salmonids have a high probability of ultimately moving into the sluiceway. Data from the tracking effort using the DIDSON in the nearfield of SL 1-3 and SL 18-3 show the zone of influence is about 20-25 ft (Figure 4.40). Note, since SL 1-3 is "upstream" of SL 1-2 and SL 1-1 the way water and fish flow along the face of The Dalles Dam, it is likely that some of the fish classified as "Not Collected" at SL 1-3 actually ended up passing at the other SL 1 entrances. We observed juvenile salmonids moving 
toward SL 1 from over $30 \mathrm{ft}$ away. On the other hand, some fish within $10 \mathrm{ft}$ of the entrance were observed moving away from SL 1 . These data are consistent with those by Johnson et al. $(2001 ; 2004)$ using the sonar tracker.

There were other noteworthy observations using the acoustic camera relevant to the zone of influence concept. Smolts displayed positive rheotaxis in the nearfield of the sluiceway, indicating a response to the sluiceway flow net; i.e., they were responding to hydraulic conditions in the zone of influence. We also often saw schools of juvenile salmonids, as opposed to individual fish, moving into the sluiceway entrances. Schools are rare at other routes such as spill bays and turbines where sounding precedes passage. Schools of juvenile salmonids in the zone of influence of the sluiceway indicate the sluiceway flow net is not disrupting natural migration behavior.

Table 4.6 and Figure 4.41 shows the sums of each spatial cell's fates (states) over the sluiceway absorbing edge after 220 multiplications of the transition matrices. The largest passage probabilities were into the West followed by Sluiceway absorbing cells for both seasons, except for spring at MU 1 where the largest fate was to the Sluiceway (Table 4.6). The Sluiceway fate varied from $29-55 \%$ with the low value occurring in spring at SL 18. No stagnation occurred, that is, all fish moved to edges of the volume analyzed. There was some Reservoir fate observed (3-10\%) but very little East fate was detected (Table 4.6).

The fish entrainment zone (FEZ) varied from 7 to $13 \mathrm{ft}$ (2.1-4.0 $\mathrm{m}$ ) (Figure 4.41). The FEZ, defined as the point where $90 \%$ of fish are entrained, was spread more to the East than to the West. In spring, the FEZ was $10 \mathrm{ft}$ near SL 1-3 and $7 \mathrm{ft}$ at SL 18-3. In summer, the FEZ was $11 \mathrm{ft}$ at SL 1-3 and $14 \mathrm{ft}$ at SL 18-3. Although the 10 to $11 \mathrm{ft}$ (3.3-3.4 m) FEZ at the SL 1-3 sluiceway is approximately half of the 6-8 $\mathrm{m}$ FEZ reported in Johnson et al. (2004) at SL 1-1, the West fate (Figure 4.41) undoubtedly includes fish movement that would ultimately pass into the SL 1-2, 1-1 and SL 18-2, 18-1 sluiceway entrances.

Table 4.6. Relative Fates Probabilities of Passage. Based on a Markov chain analysis from a semicircular area near SL 1 and 18 at The Dalles Dam, 2004.

\begin{tabular}{|cccccc|}
\hline Period & Sluiceway & West & East & Reservoir & Sluiceway \\
\hline \multirow{2}{*}{ Spring } & MU 1 & 0.41789 & 0.00040 & 0.03309 & 0.54862 \\
& MU18 & 0.67455 & 0.00076 & 0.03643 & 0.28826 \\
\hline \multirow{2}{*}{ Summer } & MU 1 & 0.53243 & 0.00080 & 0.10005 & 0.36673 \\
& MU18 & 0.47638 & 0.00050 & 0.07045 & 0.45268 \\
\hline
\end{tabular}




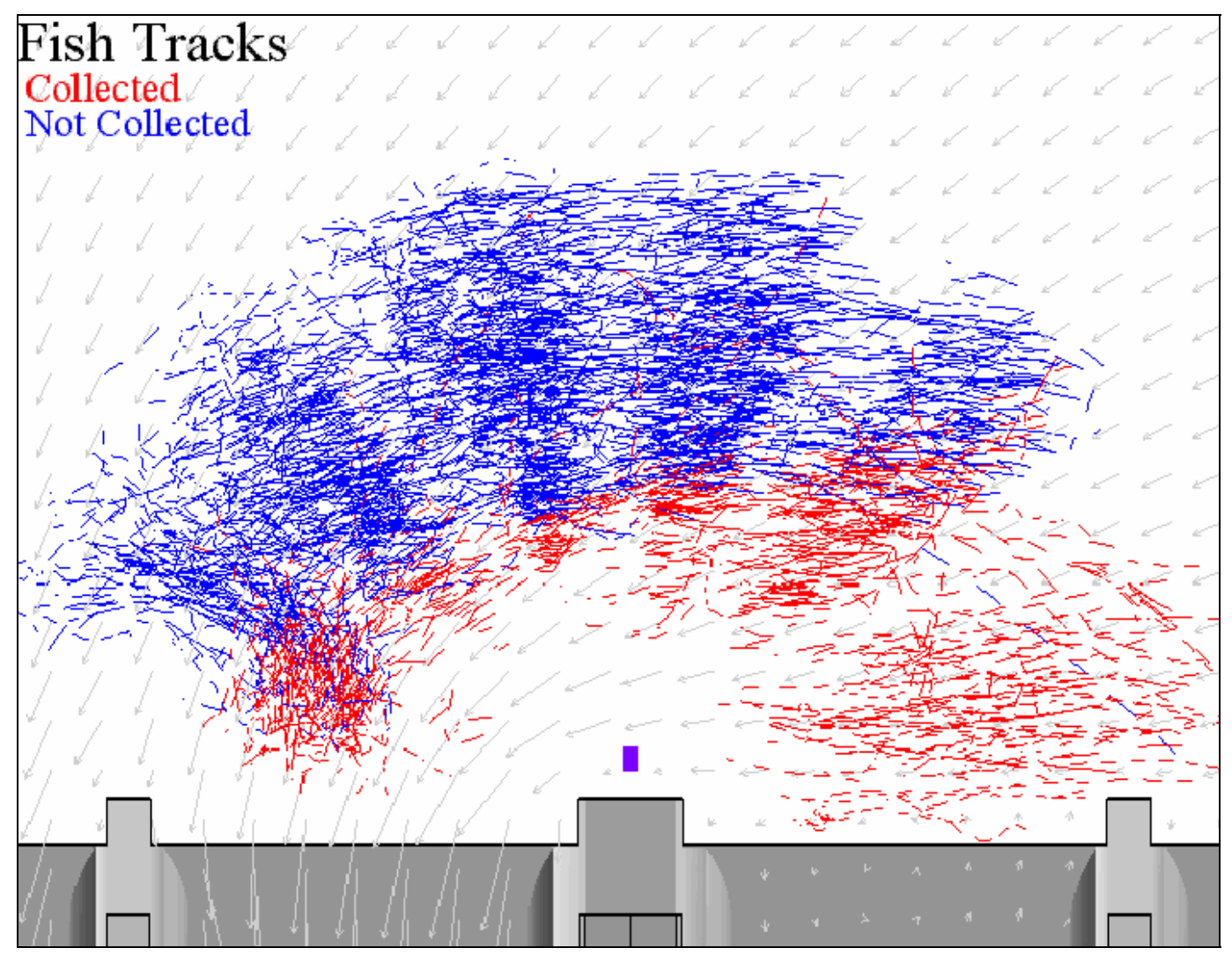

Figure 4.40. Example Individual/School Fish Tracks from May 13, 2004 for SL 1. The tracks are superimposed on CFD velocity vectors. The DIDSON is depicted by the blue box off the middle pier nose, which is the pier between MU 1 and MU 2. "Collected" or "Not Collected" was determined from the directionality analysis (Appendix B), except for tracks immediately in front of SL 2-1 (lower, right) which were assumed to have ultimately been collected because of their location relative to the open entrance at SL 1-3. Distance between sluice piers is $20 \mathrm{ft}$. 


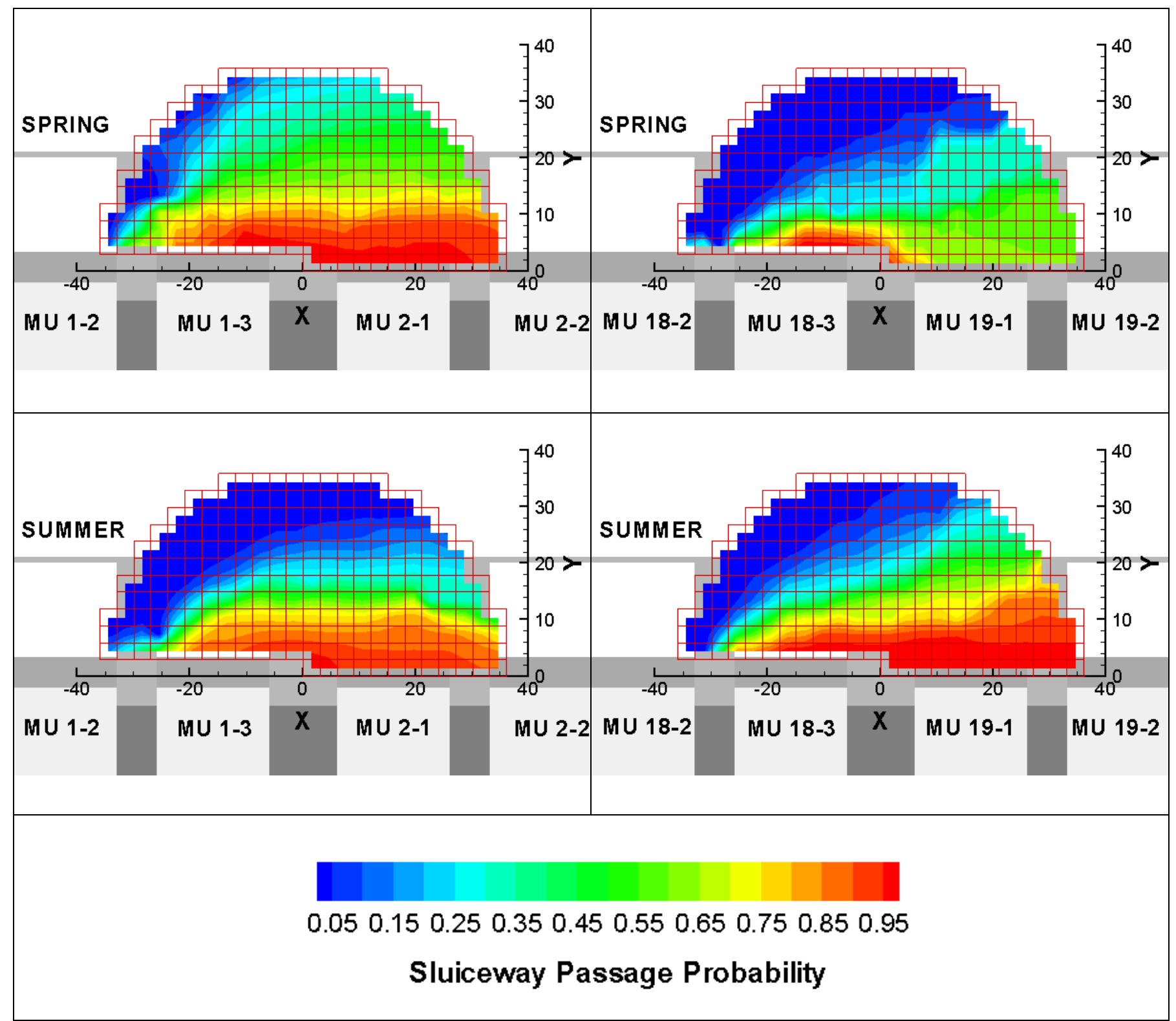

Figure 4.41. Contours of Fate Probabilities for Passage at The Dalles Dam, SL 1 and 18 for Spring and Summer 2004. Probabilities above are shown for the Sluiceway passage fates. X- and Y-scales are in feet. 


\section{Did juvenile salmonid movements in the nearfield differ between SL 1 and SL 18?}

In general, juvenile salmonid movement patterns did not differ appreciably between the two sluice entrances (Figures 4.41 and 4.42). Fish approached from the east and northeast, some moved toward and into the sluice entrance, while others continued west. Schools were observed in both locations. In fact, in the analysis of deviance, no significant difference in fish movement direction was observed between SL 1 and SL $18(\mathrm{P}=0.3959)$ (see Appendix B for more details). As mentioned above, however, the fish entrainment zone at SL 1 was larger compared to SL 18 in spring; the opposite was true in summer (Figure 4.41).
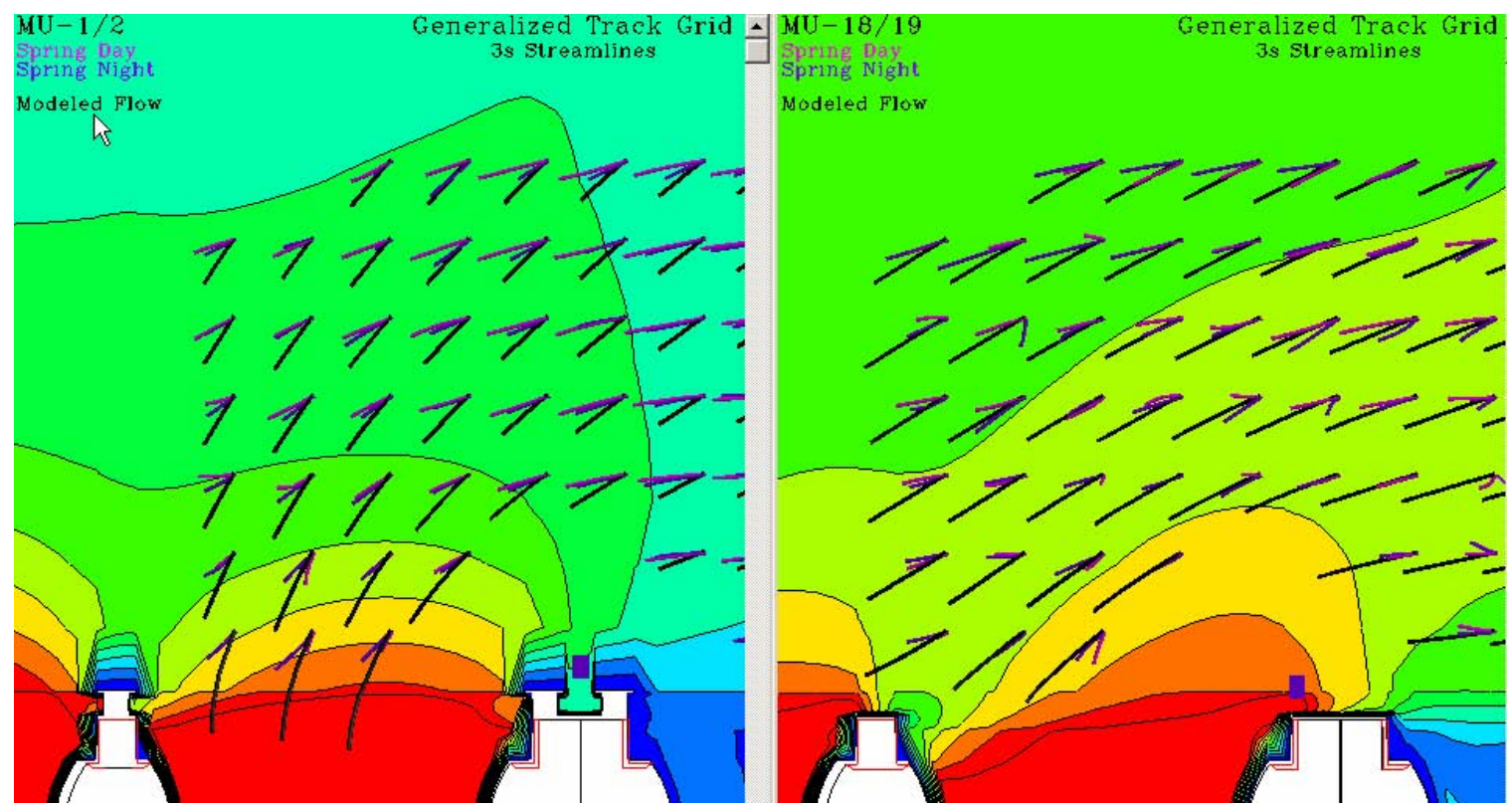

Figure 4.42. Generalized Fish Track Grid Superimposed on Water Velocity Magnitudes at SL 1 (left) and SL 18 (right). Purple and blue segments show movement pattern, direction, and speed for a given cell in the grid for day and night, respectively. Contour levels are shown on the right.

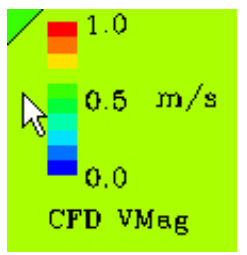


How does the zone of influence correspond with the sluiceway flow net as represented by water velocity?

On a qualitative basis, the sluiceway zone of influence appeared to correspond to the sluiceway flow net because the generalized fish tracks became more directed toward the sluice entrance the deeper they went into the sluice flow net (Figure 4.42). Also, the location of the observed zone of influence corresponded with the location of the flow net (Figure 4.42). The association between sluiceway flow net and zone of influence should be examined quantitatively using statistical methods.

Did power peaking, as represented by total powerhouse discharge, adversely affect sluiceway passage efficiency? How about if power peaking is represented by hourly difference in powerhouse discharge?

No, the hourly sluice efficiency (re: powerhouse) data did not reveal any adverse effects of variation in total hourly powerhouse discharge (Figure 4.43) nor in hourly differences in total powerhouse discharge (Figure 4.44). Trendlines for total hourly powerhouse discharge were negative for the West and West+East treatments, but the R-squared values were low at 0.05 and 0.03 , respectively (Figure 4.43). No relationship was apparent between the change in powerhouse and sluiceway efficiency (Figure 4.44). The trendlines for the relationship between the absolute value of the hourly delta powerhouse discharge and sluice efficiency were flat (Figure 4.45). In sum, the data do not indicate any association between power peaking and sluiceway efficiency.

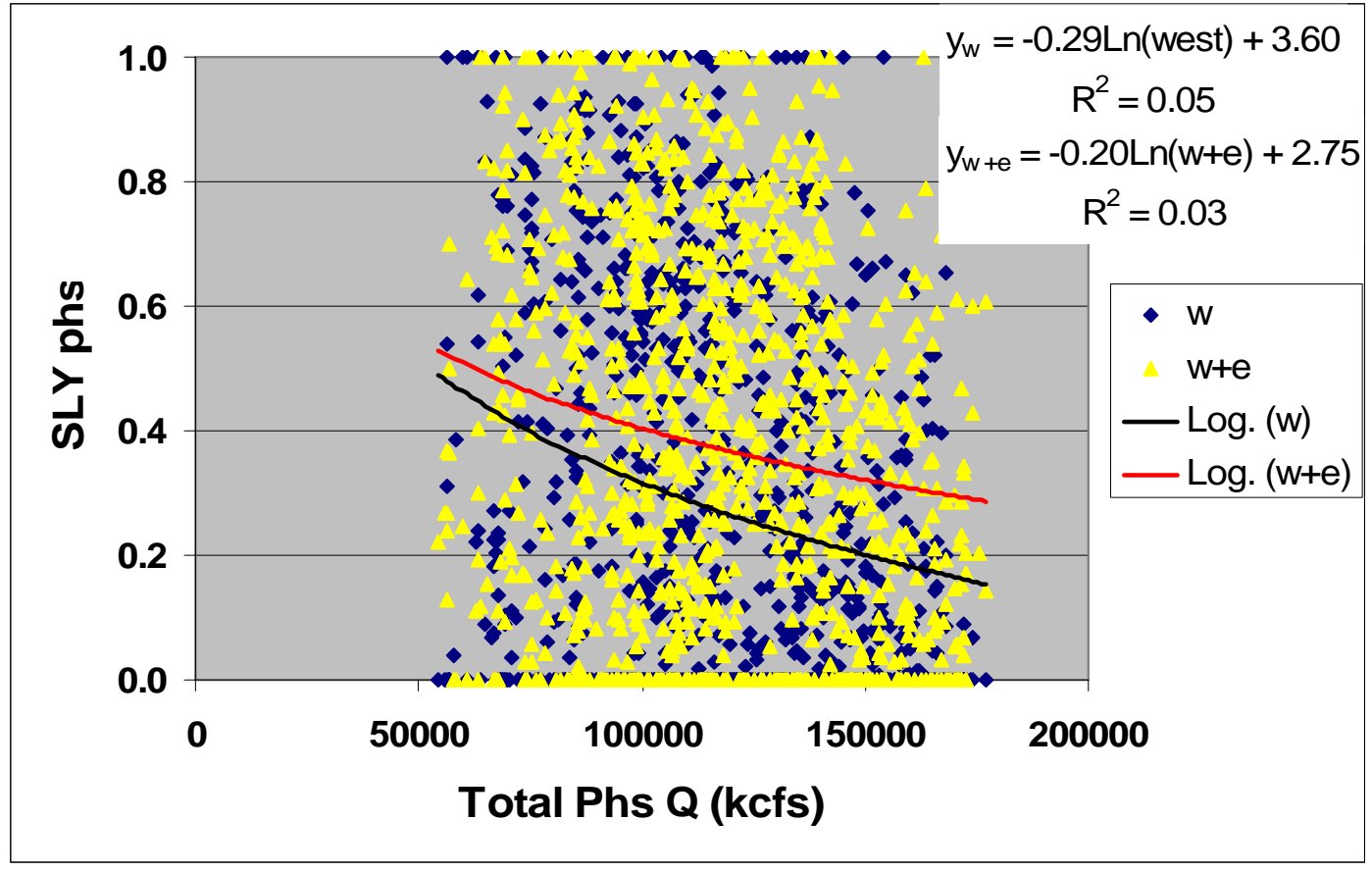

Figure 4.43. Relationship between Total Powerhouse Discharge and Sluiceway Efficiency (re: powerhouse) for West and West+East Sluice Treatments for Hourly Hydroacoustic Data for Spring and Summer Combined at The Dalles Dam in 2004. 


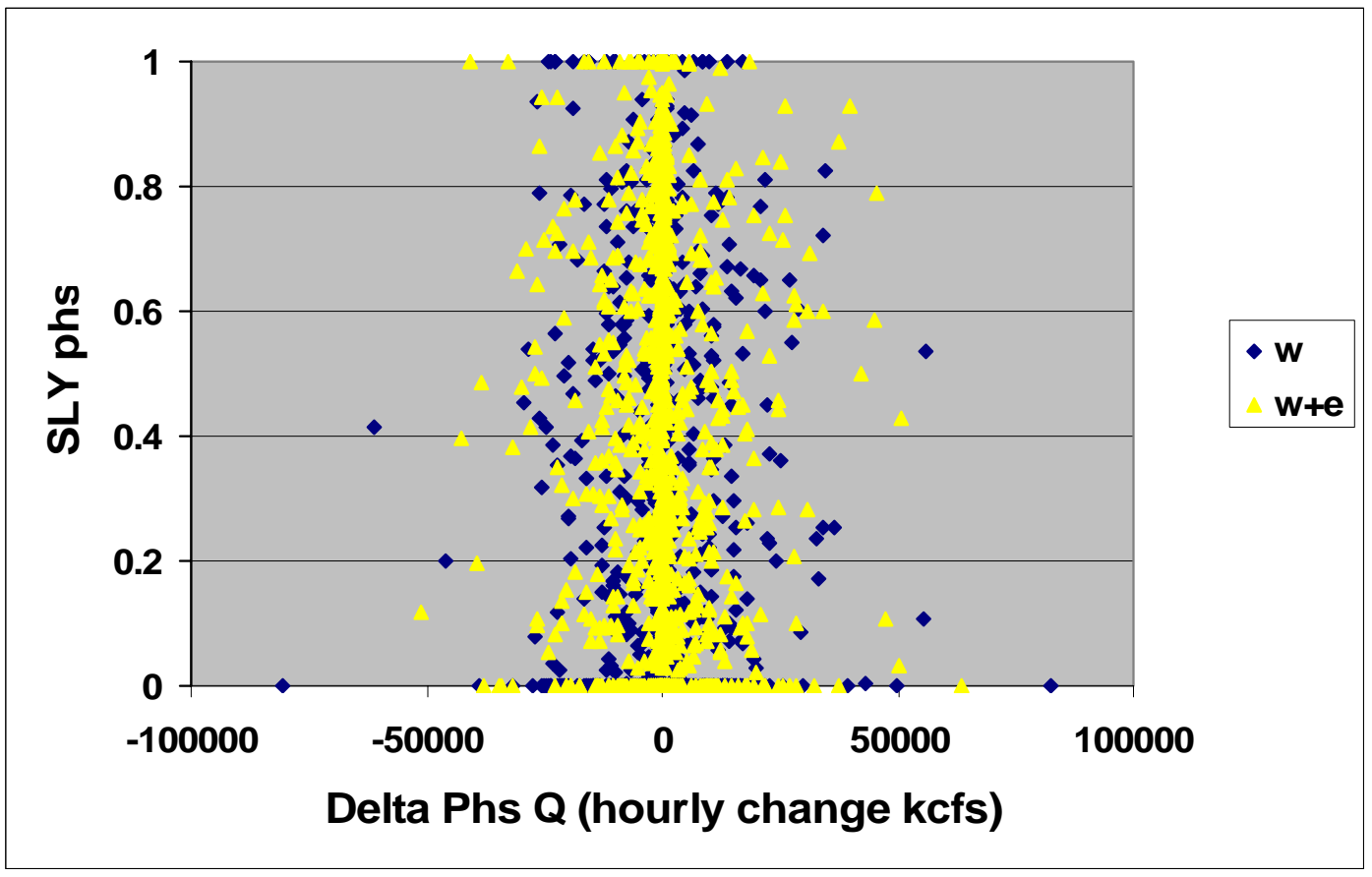

Figure 4.44. Relationship between Delta Powerhouse Discharge (hourly difference) and Sluiceway Efficiency (re: powerhouse) for West and West+East Sluice Treatments for Hourly Hydroacoustic Data for Spring and Summer Combined at The Dalles Dam in 2004.

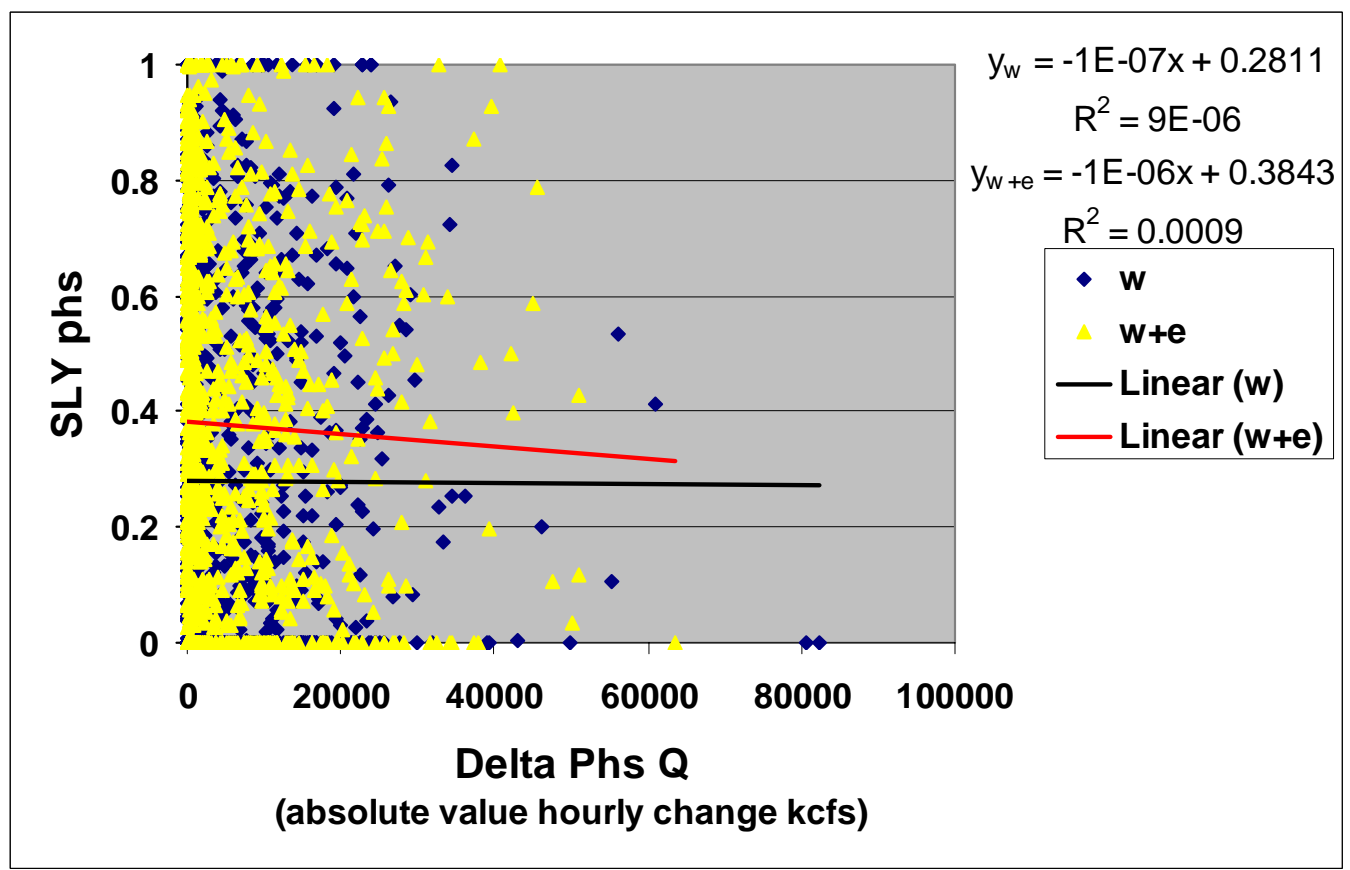

Figure 4.45. Relationship between the Absolute Value of Delta Powerhouse Discharge (hourly difference) and Sluiceway Efficiency (re: powerhouse) for West and West+East Sluice Treatments for Hourly Hydroacoustic Data for Spring and Summer Combined at The Dalles Dam in 2004. 
What was the association between sluiceway efficiency relative to total powerhouse passage and the proportions of sluice discharge out of total powerhouse discharge? In terms of water usage, how effective was the sluiceway for the powerhouse as a whole?

There was no clear association between sluiceway efficiency (re: powerhouse) and the proportion of sluice discharge (re: powerhouse). The trend, however, was positive for both treatments West and West+East, although the association expressed by the R-squared values was weak at 0.05 and 0.03 , respectively (Figure 4.46).

The sluiceway was very effective for the powerhouse as a whole. Effectiveness, defined as the ratio of the proportion of fish sluiced to the proportion of water sluiced, was 12.2 in spring and 4.6 in summer. As a comparison, overall effectiveness of the surface flow bypass at Wells Dam is about 13 (Johnson et al. 1997).

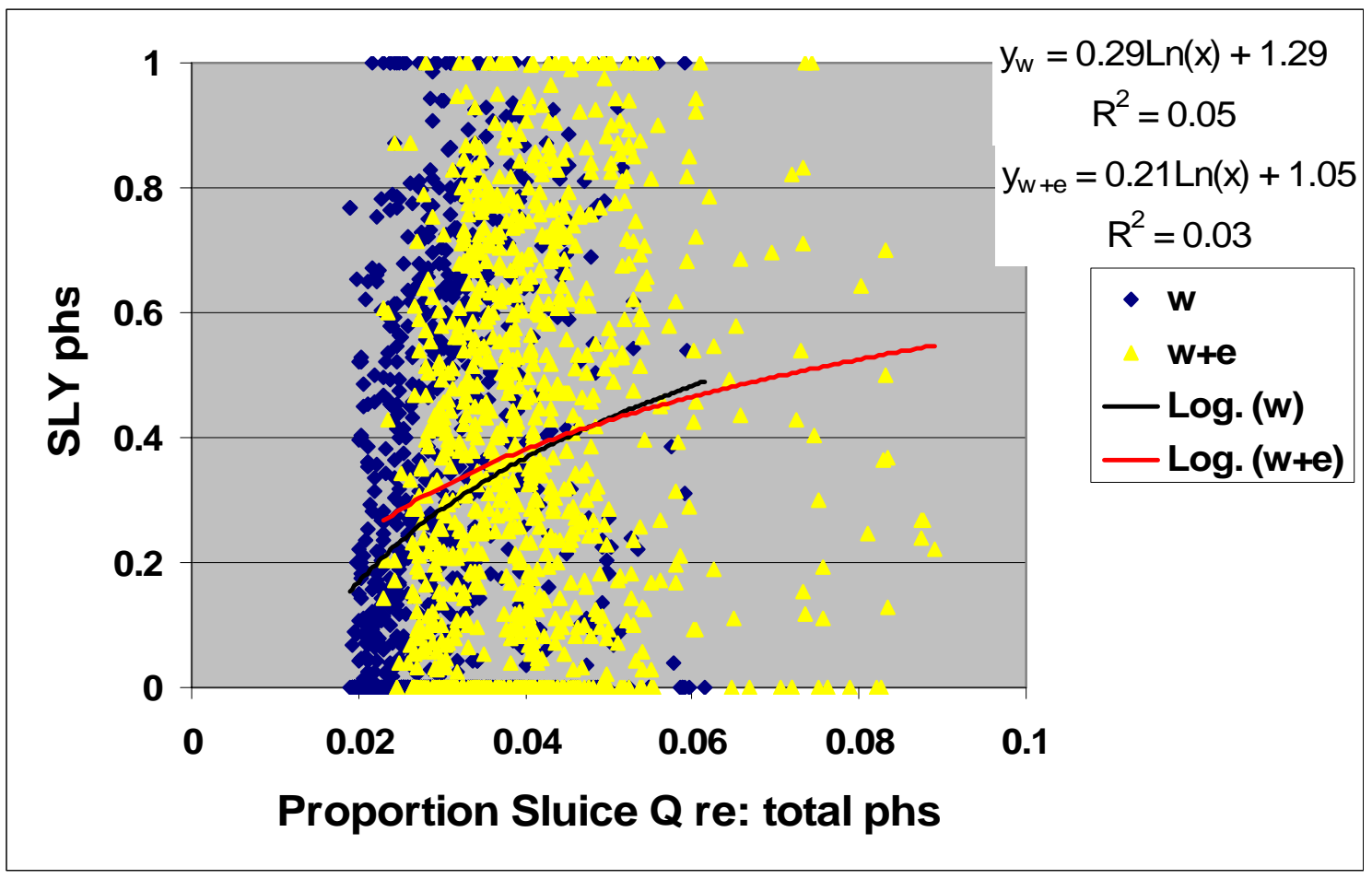

Figure 4.46. Relationship between Proportion of Total Sluice Discharge Out of Total Powerhouse Discharge and Sluiceway Efficiency (re: powerhouse) for West and West+East Sluice Treatments for Hourly Hydroacoustic Data for Spring and Summer Combined at The Dalles Dam in 2004. 
What was the association between sluiceway efficiency relative to west (FU1 to MU5) powerhouse passage and the proportion of west sluice discharge out of total west powerhouse discharge?

The association between sluiceway efficiency (re: west powerhouse, FU1 to MU5) and the proportion of west sluice discharge at the west powerhouse (FU1 to MU5) was negative and relatively strong (Figure 4.47). The highest proportions of sluice discharge occurred when MU1 and MU2, below the west sluice at SL1, were off line unexpectedly in summer 2004.

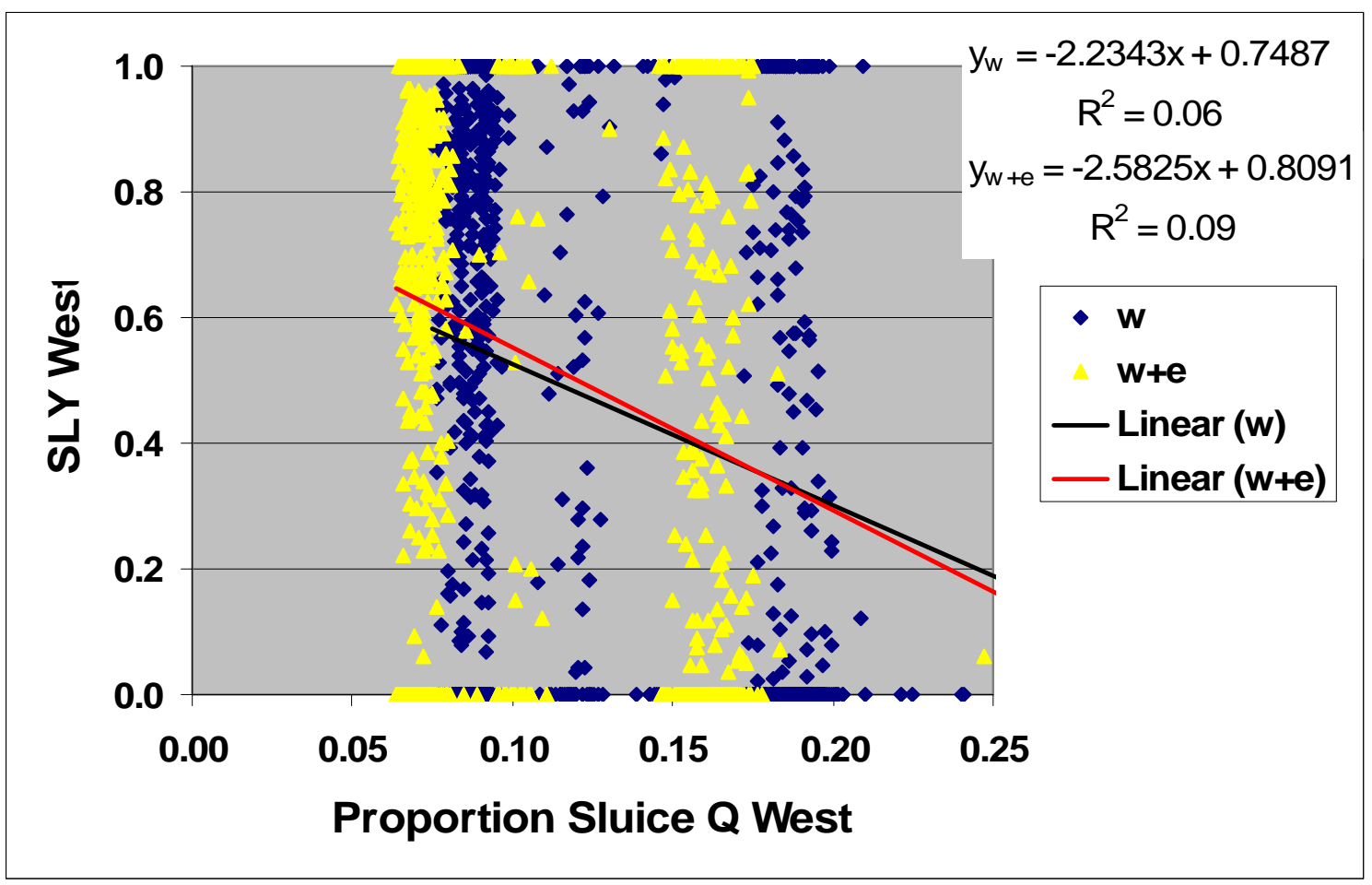

Figure 4.47. Relationship between Proportion of West Sluice (SL1) Discharge Out of West (FU1 to MU5) Powerhouse Discharge and Sluiceway Efficiency (re: west powerhouse) for West and West+East Sluice Treatments for Hourly Hydroacoustic Data for Spring and Summer Combined at The Dalles Dam in 2004. 
What was the association between sluiceway efficiency relative to east (MU17 to MU22) powerhouse passage and the proportion of east sluice discharge out of total east powerhouse discharge?

The association between sluiceway efficiency (re: east powerhouse, MU17-22) and the proportion of east sluice discharge at the east powerhouse (MU17-22) was positive, but weak (Figure 4.48). These results are affected by three data points with sluice efficiency equal to 1 at the highest sluice discharges.

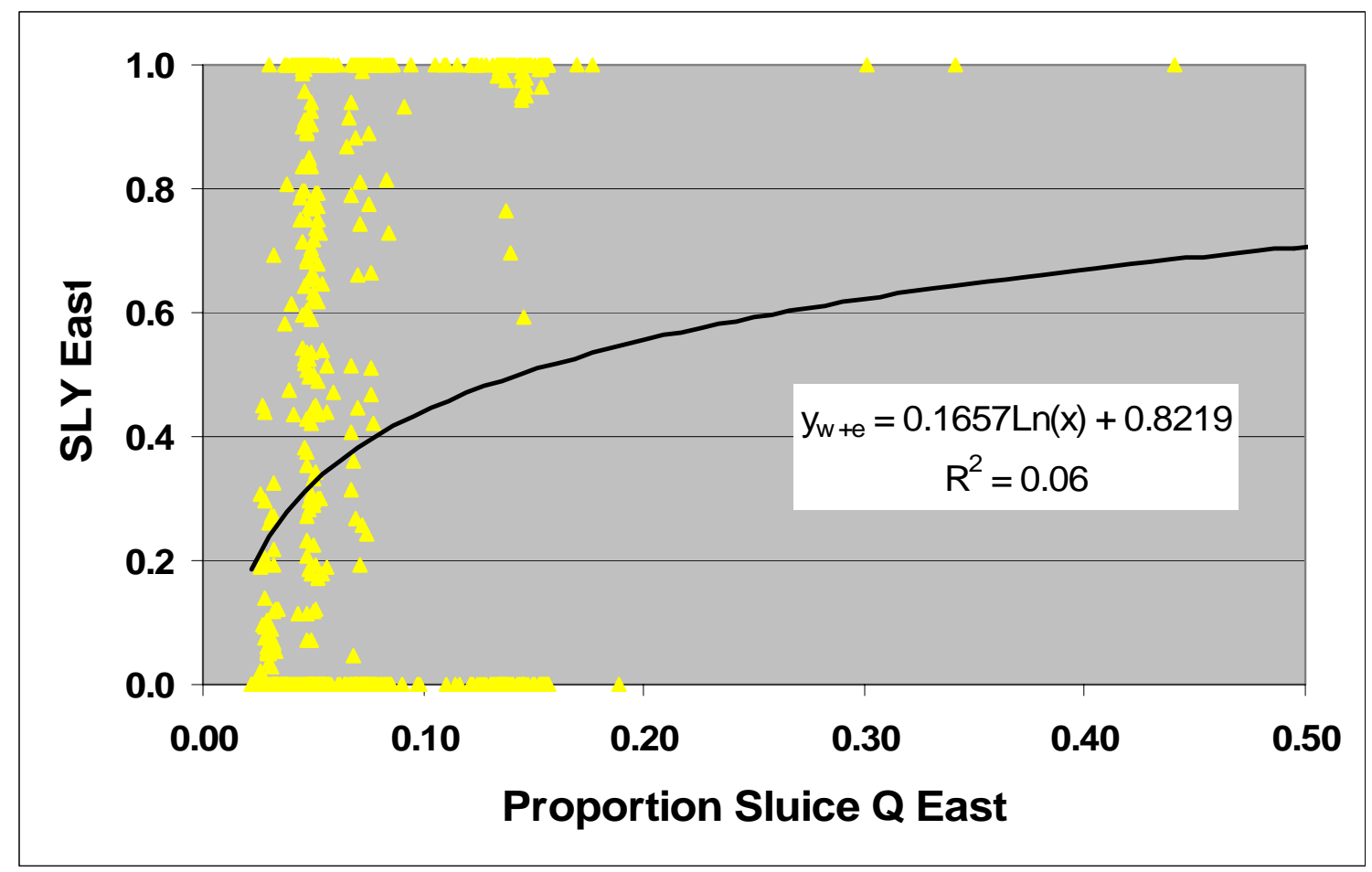

Figure 4.48. Relationship between Proportion of East Sluice (SL18) Discharge Out of East (MU17 to MU22) Powerhouse Discharge and Sluiceway Efficiency (re: east powerhouse) for the West+East Sluice Treatment for Hourly Hydroacoustic Data for Spring and Summer Combined at The Dalles Dam in 2004. 
Hydroacoustic Evaluation of Juvenile Salmonid Passage at The Dalles Dam in 2004 


\subsection{Discussion}

In this section we discuss data integrity, the fish passage evaluation, and the sluiceway evaluation.

\subsection{Data Comparison}

The latest fixed-location hydroacoustic and radio telemetry data for the sluiceway are presented in Table 5.1. Trends in the sluice passage data revealed by the two techniques comport well. First, the majority of sluice passage was at the west sluice (SL 1), especially in spring. Second, the proportion of fish passing into the sluiceway at the east sluice (SL 18) was higher in summer than spring. And, third, the sluiceway as a whole was an important non-turbine passage route, based on sluiceway efficiencies relative to the powerhouse and total project. Each data set had days of no passage at SL 18, although passage rates from hydroacoustics were higher than those from radio telemetry, especially during summer, at the SL 18 sluice entrance.

Table 5.1. Proportion of Total Sluiceway Passage for SL 1 and SL 18 and Sluiceway Efficiencies (SLY) by Season Separately for Hydroacoustics (HA) and Radio Telemetry (RT) Studies at The Dalles Dam in 2004. Radio telemetry data for spring (yearling Chinook salmon) and summer (subyearling Chinook salmon) obtained for SL 1 and SL 18 from H. Hansel (pers. comm., USGS, December 16, 2004) and for SLY from Hansel et al. (2005; calculated from data on p.6). Data for the two sluice treatments (West and West+East) are pooled.

\begin{tabular}{|l|c|c|c|c|}
\hline & \multicolumn{2}{|c|}{ Spring } & \multicolumn{2}{c|}{ Summer } \\
\hline & HA & RT & HA & RT \\
\hline SL 1 re: total sluice & $90 \%$ & $99 \%$ & $60 \%$ & $94 \%$ \\
\hline SL 18 re: total sluice & $10 \%$ & $1 \%$ & $40 \%$ & $6 \%$ \\
\hline SLY re: powerhouse & $44 \%$ & $55 \%$ & $18 \%$ & $32 \%$ \\
\hline SLY re: total project & $7 \%$ & $9 \%$ & $4 \%$ & $7 \%$ \\
\hline
\end{tabular}

No single reason is readily apparent as to why east sluice (SL 18) passage was relatively higher as estimated using hydroacoustic techniques than as estimated by radio telemetry. There are differences between the techniques in species composition and size distribution of the sampled population, sample sizes, sample locations, and time periods sampled. Some combination of these factors is probably involved at the relatively small spatial scale of the east sluice in the forebay of The Dalles Dam. In general, consistency of results between hydroacoustic and telemetry techniques is positively correlated with the spatial and temporal scales being examined; that is, the larger the spatial scale and/or longer the temporal scale, the more consistent the hydroacoustic and telemetry results will be. For the east sluice, the discrepancy between hydroacoustic and telemetry results may be simply the result of relative spatial scale for the small SL 18 portal in the forebay of the large TDA project. While each technique has its advantages and disadvantages, hydroacoustics and telemetry are basically complementary and should be applied in conjunction whenever possible. 


\subsection{Fish Passage Evaluation}

The fish passage evaluation at The Dalles Dam in 2004 demonstrated that a $40 \%$ spill rate combined with open sluiceway entrances resulted in fish passage efficiencies exceeding 0.90 in spring and 0.80 in summer. These data are consistent with data from 1998 and 2000, somewhat higher than data from 1999 and 2001 (spring only), and dramatically higher than data from 2002, the year of the J-occlusion plate evaluation. In 2003, fish passage was not evaluated with hydroacoustics. Year-to-year variability in fish passage efficiency at The Dalles Dam should be factored into fisheries management decisions.

\subsection{Sluiceway Evaluation}

Previous researchers studied the passage survival of juvenile salmon at the TDA sluiceway using releases PIT tagged fish in 1998 (Dawley et al. 2000) and 2000 (cited in Ploskey et al. 2001a). In 1998, relative survival rates for juvenile coho salmon and subyearling Chinook salmon were $96 \%$ (95\% CI: 87 $105 \%$ ) and $89 \%$ (95\% CI: 81-98\%), respectively. In 2000, sluiceway survival rates were 95\% (95\% CI: 92-98) for yearling coho salmon and 96\% (95\% CI: 88-104\%) for subyearling Chinook salmon.

Therefore, passage survival at the sluiceway is high enough to warrant enhancements of the sluiceway as a non-turbine route at The Dalles Dam.

Fixed-location hydroacoustic and acoustic camera data collected for the sluiceway evaluation showed that juvenile salmonids passed into the experimental east end sluice entrance (SL 18). Total sluiceway passage and sluiceway efficiency (re: powerhouse) generally were higher with six gates open (the West+East treatment) than with three gates open (the West-only treatment). Although the majority of fish passage into the sluiceway occurred through the west gates (SL 1), opening the east gates provided an incremental benefit to total sluice passage of about $11 \%$ in spring and about $65 \%$ in summer. And, although the statistical comparisons between West and West+East treatments for total sluice passage, sluice efficiency, and east turbine passage were not usually significant, the data do not indicate any negative effects of opening six gates as opposed to three gates. The lack of significance was the result of the high variability in daily total sluice passage. Furthermore, the amount of total flow into the sluiceway increased when three additional gates were opened (e.g., 3,138 cfs for three gates vs. 4,451 cfs for six gates, forebay elevation $158.4 \mathrm{ft}$, Table 2.1). This additional flow, especially since it came from the forebay surface waters, will naturally contain juvenile salmonids during the spring and summer emigration seasons. In conclusion, the hydroacoustic data indicate it is better for juvenile fish protection at The Dalles Dam to open six rather than three sluice gates to take advantage of the maximum hydraulic capacity of the sluiceway.

The optimum location for opening sluice gates remains a question. The 2004 sluiceway evaluation examined the notion that east-end sluice gates would pass appreciable numbers of fish because the majority of radio-tagged fish in previous studies were first detected in the forebay off the east end of the powerhouse (Sheer et al. 1997; Holmberg et al. 1997; Hensleigh et al. 1999; Hansel et al. 2000) and because passage rates estimated from hydroacoustic data were relatively high at east turbine units when they were operated, especially in summer (Ploskey et al. 2001a; Johnson et al. 2003). The east end gates in 2004, however, were not a resounding success for fish passage. Opening the east end gates helped, as discussed above, but it is possible the incremental benefit the east end gates provided to total sluiceway passage could have been gained at another location. On the other hand, the 2004 data did validate the convention of operating the three west end gates at SL 1. Given the apparent advantage of six over three 
gates, it might be useful to examine whether opening three additional gates in the middle part of the dam is better than opening three gates at the east end. Three possible sluiceway operations for 2005 are:

- Sluice entrances SL 1-1, 1-2, 1-3 and SL 18-1, 18-2, 18-3 (repeat 2004 operation)

- Sluice entrances SL 1-1, 1-2, 1-3 and SL 11-1, 11-2, 11-3

- Sluice entrances SL 1-1, 1-2, 1-3 and SL 2-1, 2-2, 2-3.

Another concern for fish operations at The Dalles Dam is whether to operate turbine units beneath open sluice gates or not as a standard procedure. In 2004, passage rates into both the west and east sluice entrance were higher with the turbine units operating below and adjacent to the open sluices (Table 5.2). This finding is consistent with sluiceway evaluations at Ice Harbor Dam in 1982 and 1983 (Johnson et al. 1983). Therefore, we believe turbine units below open sluice gates should be operated as a standard fish operations procedure.

Table 5.2. Mean Hourly Passage Rates at the West (SL1) and East (SL18) Sluice Entrances by Operation of Main Units Below and Adjacent to the Open Sluice.

\begin{tabular}{|ccc|ccc|}
\hline MU1 & MU2 & Mean SL1 & MU18 & MU19 & Mean SL18 \\
\hline On & On & 99 & On & On & 37 \\
On & Off & 19 & On & Off & 34 \\
Off & Off & 36 & Off & Off & 21 \\
\hline
\end{tabular}

The effect of power peaking on fish is a concern to fisheries resource managers and hydroelectric project owner/operators. This is especially true for in-stream flows and fish populations below a project. For passing juvenile salmonids through a forebay and into a dam, the primary concern is whether power peaking increases turbine passage with its attendant higher mortality rate than non-turbine routes. Our exploratory analysis did not reveal any association between sluiceway efficiency and power peaking as represented by total discharge and hourly delta discharge. The estimator for sluiceway efficiency incorporates turbine passage. On a diel basis, turbine passage did not increase during the morning hours when power production peaked $(0600-1000 \mathrm{~h})$. Therefore, the 2004 hydroacoustic data did not indicate adverse effects of power peaking on fish passage, although the study was not designed to address this question. Future studies could be designed to address hypothesized effects of power peaking on juvenile salmonid passage at The Dalles Dam.

Another parameter of interest at The Dalles Dam for fish operations is sluiceway discharge, specifically, the proportion of sluice discharge out of total powerhouse discharge. Sluice discharge proportion is related to the concept of opportunity for discovery for a surface flow bypass such as the sluiceway, i.e., are the juvenile salmonids exposed to the sluiceway flow nets? The opportunity for discovery is presumably positively correlated with the size of the sluiceway flow net and the level of horizontal concentration of naturally surface-oriented fish at the surface flow bypass entrance. The Dalles Dam sluiceway does not have a pronounced horizontal concentration of fish in the forebay like, for example, the Bonneville Second Powerhouse Corner Collector. However, in 2004, TDA did have variable sluiceway and turbine discharges, and hence sluice discharge proportions, allowing us to explore the relationship between sluiceway fish passage efficiency and sluice discharge proportion. The relationship was positive for the powerhouse as a whole and for the east end sluice, but it was negative for the west end sluice. High sluice discharge proportions resulted when turbine units were off below the open sluice entrances. However, as discussed above, sluice passage appears to be enhanced when the 
units below sluiceway entrances are operating. The relationship between sluice discharge proportion (and absolute sluice discharge for that matter) and sluiceway efficiency should be examined further.

Sluiceway discharge is fundamental to the efficacy of sluiceway enhancements at The Dalles Dam. As a design parameter, sluiceway discharge is consistent with the considerations for surface flow bypasses identified by Johnson et al. (2004): 1) form an extensive surface flow bypass flow net (surface bypass discharge greater than $\sim 7 \%$ of total project discharge); 2) create a gradual increase in water velocity approaching the surface flow bypass (ideally, acceleration $<1 \mathrm{~m} / \mathrm{s} / \mathrm{m}$ ); 3 ) make water velocities at an entrance high enough ( $>3 \mathrm{~m} / \mathrm{s})$ to entrain the subject juvenile fishes; 4$)$ adapt the shape and orientation of the surface entrance(s) to fit site-specific features; and 5) consider installing a forebay wall to increase fish availability to the surface flow bypass. These elements should be considered during design of sluiceway enhancements at The Dalles Dam.

Sluiceway enhancement could be a reliable, long-term strategy for juvenile salmonid passage at The Dalles Dam. Because of the variability among years in spill efficiency (Ploskey et al. 2001a), spillway improvements alone may not be sufficient to protect juvenile salmonids across the entire dam during every annual emigration. Surface flow bypasses are being designed, installed, and operated as long-term juvenile salmonid passage routes at a growing number of mainstem dams. Examples include the "Removable Spillway Weirs" at Lower Granite and Ice Harbor dams and the "Corner Collectors" at Bonneville and Rocky Reach dams. Therefore, a diverse, multi-faceted approach that includes sluiceway enhancements as a surface flow bypass at the powerhouse is in order. Data have repeatedly shown that The Dalles Dam sluiceway has the potential to be highly efficient and effective at passing juvenile salmonids, especially when assessed relative to powerhouse passage. This potential could be tapped with hydraulic and entrance enhancements to the sluiceway. 


\subsection{Recommendations}

The overall goal of this study was to provide information on smolt passage at The Dalles Dam to support decisions on long-term measures and operations to increase sluiceway and spill passage and reduce turbine passage to improve smolt survival at the dam. In 2004, the hydroacoustic evaluation of juvenile salmonid passage at The Dalles Dam involved fixed-location hydroacoustic methods across the entire project. Sampling was especially intensive at the sluiceway where multiple split-beam transducers to sample fish passage were complemented by an acoustic camera to track fish in the sluiceway nearfield. The fish data were interpreted and integrated with hydraulic data from a CFD model and in-field ADCP measurements. An "experiment" was conducted to compare two sluiceway operations: West only (SL 1) vs. West+East (SL 1 + SL 18). Our findings were listed by objective in the Summary section at the beginning of the report.

To enhance sluiceway and spillway passage and reduce turbine passage at The Dalles Dam, our recommendations for sluiceway operations and long-term measures are to:

- Open six rather than three sluice gates to take advantage of the maximum hydraulic capacity of the sluiceway.

- Test sluice gate operations in 2005 in one or more of the following combinations of six gates:

o SL 1-1, 1-2, 1-3 and SL 18-1, 18-2, 18-3 (repeat 2004 operation)

o SL 1-1, 1-2, 1-3 and SL 11-1, 11-2, 11-3

o SL 1-1, 1-2, 1-3 and SL 2-1, 2-2, 2-3.

- Operate the turbine units below open sluice gates as a standard fish operations procedure.

- Develop hydraulic and entrance enhancements to the sluiceway to tap the potential of The Dalles Dam sluiceway to be highly efficient and effective at passing juvenile salmonids.

- Consider the following elements for surface flow bypasses during design of any sluiceway enhancements at The Dalles Dam:

$0 \quad$ Form an extensive surface flow bypass flow net (surface bypass discharge greater than $\sim 7 \%$ of total project discharge).

o Create a gradual increase in water velocity approaching the surface flow bypass (ideally, acceleration $<1 \mathrm{~m} / \mathrm{s}$ per meter).

o Make water velocities at an entrance high enough $(>3 \mathrm{~m} / \mathrm{s})$ to entrain the subject juvenile fishes.

0 Adapt the shape and orientation of the surface entrance(s) to fit site-specific features.

o Consider installing a forebay wall to increase fish availability to the surface flow bypass. 
Hydroacoustic Evaluation of Juvenile Salmonid Passage at The Dalles Dam in 2004 


\subsection{References}

Beeman, J., H. Hansel, P. Haner, and K. Daniel. 2004. Estimate fish, spill, and sluiceway passage efficiencies of radio-tagged juvenile steelhead and yearling Chinook salmon at The Dalles Dam, 2001. Draft final report of research by the USGS Biological Resources Division submitted to the U.S. Army Corps of Engineers - Portland District. October 10, 2002.

Carlson, T. J., W. C. Acker, , and D. M. Gaudet. 1981. Hydroacoustic assessment of downstream migrant salmon and steelhead at Priest Rapids Dam in 1980. Seattle, Washington: Applied Physics Laboratory, University of Washington; 1981; APL-UW 8016.

Cash, K. and 13 co-authors. 2005. Three-dimensional behavior and passage of juvenile salmonids at The Dalles Dam, 2004. Draft final report by the USGS Biological Resources Division and PNNL submitted to the U.S. Army Corps of Engineers - Portland District. February 2005.

Dawley, E. M,. L. G. Gilbreath, R. F. Absolon, B. P. Sandford, and J. W. Ferguson. 2000. Relative survival of juvenile salmon passing through the spillway and the ice and trash sluiceway of The Dalles Dam, 1998. Final report by the National Marine Fisheries Service submitted to the U.S. Army Corps of Engineers - Portland District.

Faber, D. M,. M. E. Hanks, S. A. Zimmerman, J. R. Skalski, and P. W. Dillingham. 2005. The distribution and flux of fish in the forebay of The Dalles Dam in 2003. Final report by PNNL submitted to the U.S. Army Corps of Engineers - Portland District. PNNL-14628.

Hansel, H. C., and six co-authors. 2000. Estimates of fish-, spill-, and sluiceway passage efficiencies of radio-tagged juvenile steelhead and yearling Chinook salmon at The Dalles Dam, 1999. Annual report of research, 1999, by the USGS Biological Resources Division submitted to the U.S. Army Corps of Engineers - Portland District.

Hansel, H. C., and six co-authors. 2005. Estimates of fish-, spill-, and sluiceway passage efficiencies of radio-tagged juvenile Chinook salmon at The Dalles Dam in 2004. Draft final report of research during 2004 by the USGS Columbia River Research Laboratory submitted to the U.S. Army Corps of Engineers - Portland District. April 21, 2005.

Hausmann, B., J. Beeman, H. Hansel, S. Juhnke, and P. Haner. 2004. Estimates of fish, spill, and sluiceway passage efficiencies of radio-tagged juvenile salmonids relative to the Sluiceway Guidance Improvement Device at The Dalles Dam in 2002. Final report of research prepared by the USGS Biological Resources Division for the U.S. Army Corps of Engineers -- Portland District.

Hedgepeth, J. B., G. E. Johnson, A. E. Giorgi, and J. R. Skalski. 2002a. Sonar tracker evaluation of fish movements relative to J-occlusions at The Dalles Dam in 2001. Final report submitted by Battelle to U.S. Army Corps of Engineers - Portland District. March 8, 2002.

Hedgepeth, J., G. Johnson, J. Skalski, and J. Burczynski. 2002b. Active fish tracking sonar (AFTS) for assessing fish behavior. Acta Acustica 88: 739-742.

Hensleigh, J. E. and nine co-authors. 1999. Movement, Distribution, and Behavior of Radio-Tagged 
Juvenile Chinook Salmon and Steelhead in John Day, The Dalles and Bonneville Dam Forebays, 1997. Annual Report of Research, 1997, by the U.S. Geological Survey submitted to the U.S. Army Corps of Engineers - Portland District.

Holmberg, G. S. and eight co-authors. 1997. Movement, Distribution, and Behavior of Radio-Tagged Juvenile Chinook Salmon in John Day, The Dalles, and Bonneville Dam Forebays, 1996. Annual Report of Research, 1996, by the U.S. Geological Survey submitted to the U.S. Army Corps of Engineers - Portland District.

Johnson, G.E., J.B. Hedgepeth, J.R. Skalski, and A.E. Giorgi. 2004. A Markov chain analysis of fish movement to determine entrainment zones. Fisheries Research 69: 349-358.

Johnson, G.E., M.E. Hanks, J.B. Hedgepeth, B.D. McFadden, R.A. Moursund, R.P. Mueller, and J.R. Skalski. 2003. Hydroacoustic evaluation of turbine intake J-occlusions at The Dalles Dam in 2002. Final report by Battelle submitted to the U.S. Army Corps of Engineers - Portland District. PNWD-3226.

Johnson, G.E., J.B. Hedgepeth, A.E. Giorgi, and J.R. Skalski. 2001. Evaluation of Smolt Movements Using an Active Fish Tracking Sonar at the Sluiceway Surface Bypass, The Dalles Dam, 2000. Final report by BioAnalysts, Inc. submitted to the U.S. Army Corps of Engineers - Portland District.. September 30, 2001.

Johnson, G. E., A. E. Giorgi, and M. W. Erho. 1997. Critical assessment of surface flow bypass development in the Lower Columbia and Snake rivers. Completion report by PNNL submitted to the U.S. Army Corps of Engineers - Walla Walla District.

Johnson, L., Noyes, C., and McClure, R. 1983. Hydroacoustic evaluation of the efficiencies of the ice and trash sluiceway and spillway at Ice Harbor Dam for passing downstream migrating juvenile salmon and steelhead,1983. Volume I. Draft report by BioSonics, Inc. submitted to the U.S. Army Corps of Engineers - Walla Walla District.

Karlin, S., 1968. A First Course in Stochastic Processes. Academic Press, New York.

Kemeny, J. G. and J. L. Snell, 1960. Finite Markov Chains. D. Van Nostrand Company, Inc., Princeton, New Jersey.

MacLennan, D.N. and E. J. Simmonds. 1992. Fisheries Acoustics. Chapman and Hall, London, 325 pp.

Moursund, R. A., K. D. Ham, P. S. Titzler, R. P. Mueller, G. E. Johnson, J. Hedgepeth, and J. R. Skalski. 2002. Hydroacoustic evaluation of fish passage at The Dalles Dam in 2001. Report by Battelle's Pacific Northwest Division to the U.S. Army Corps of Engineers - Portland District.

Moursund, R.A., K.D. Ham, B.D. McFadden, and G.E. Johnson. 2001. Hydroacoustic evaluation of downstream fish passage at The Dalles Dam in 2000. Report by Battelle's Pacific Northwest Division to the U.S. Army Corps of Engineers - Portland District.

National Marine Fisheries Service. 2000. Re-initiation of Consultation on Operation of the Federal Columbia River Power System, including the Juvenile Fish Transportation Program, and 19 Bureau of Reclamation Projects in the Columbia Basin. Biological Opinion. December 21, 2000, National Marine Fisheries Service, Northwest Region, Seattle, Washington.

Nichols, D. W. 1979. Passage Efficiency and Mortality Studies of Downstream Migrant Salmonids Using The Dales Ice-Trash Sluiceway During 1978. Oregon Department of Fish and Wildlife. Processed Report. 28 pp. 
Nichols, D. W. 1980. Development of Criteria for Operating the Trash Sluiceway at The Dalles Dam as a Bypass System for Juvenile Salmonids, 1979. Oregon Department of Fish and Wildlife, Processed Report submitted to the U.S. Army Corps of Engineers - Portland District.

Nichols, D. W., and B. H. Ransom. 1981. Development of The Dalles Dam Trash Sluiceway as a Downstream Migrant Bypass System, 1980. Oregon Department of Fish and Wildlife, Processed Report submitted to the U.S. Army Corps of Engineers - Portland District.

Nichols, D. W., and B. H. Ransom. 1982. Development of The Dalles Trash Sluiceway as a Downstream Migrant Bypass System, 1981. Annual Progress Report, Fish Research Project Oregon, Fish Division, Oregon Department of Fish and Wildlife, submitted to the U.S. Army Corps of Engineers - Portland District.

Ploskey G., T. Poe, A. Giorgi, and G. Johnson. 2001a. Synthesis of Radio Telemetry, Hydroacoustic, and Survival Studies of Juvenile Salmon at The Dalles Dam (1982-2000). Final report submitted by Battelle to the U.S. Army Corps of Engineers - Portland District. PNWD-3131.

Ploskey, G. R., W. T. Nagy, L. R. Lawrence, M. E. Hanks, C. R. Schilt, P. N. Johnson, G. E. Johnson, D. S. Patterson, and J. R. Skalski. 2001b. Hydroacoustic evaluation of juvenile salmon passage at The Dalles Dam: 1999. ERDC/EL TR-01-11, U. S. Army Engineer Research and Development Center, Vicksburg, MS.

Sheer, M. B., G. S. Holmberg, R. S. Shively, H. C. Hansel, T. L. Martinelli, T. P. King, C. N. Frost, T. P. Poe, J. C. Snelling, and C. B. Shreck. 1997. Movement and Behavior of Radio-Tagged Juvenile Spring and Fall Chinook Salmon in The Dalles and John Day Dam Forebays, 1995. Annual Report, 1995 to the U.S. Army Corps of Engineers - Portland District.

Taylor, H. and S. Karlin. 1998. An Introduction To Stochastic Modeling. Academic Press, San Diego, California.

Thorne, R. and G. Johnson. 1993. A review of hydroacoustic studies for estimation of salmonid downriver migration past hydroelectric facilities on the Columbia and Snake rivers in the 1980s. Reviews in Fisheries Science 1: 27-56. 
Hydroacoustic Evaluation of Juvenile Salmonid Passage at The Dalles Dam in 2004 


\title{
Appendix A
}

\section{Statistical Synopsis for the 2004 Fixed-Location Hydroacoustic Investigations at The Dalles Dam}

\author{
Prepared for: \\ Gary E. Johnson \\ Pacific Northwest National Laboratory \\ 4620 SW Fifth Avenue, Suite 810 \\ Portland, Oregon 97204
}

\author{
Prepared by: \\ John R. Skalski \\ Columbia Basin Research \\ School of Aquatic and Fishery Sciences \\ University of Washington \\ 1325 Fourth Avenue, Suite 1820 \\ Seattle, Washington 98101
}

10 May 2004

(Formatted, updated, and acronyms edited by G. Johnson on 12 January 2005) 



\section{Appendix A}

\section{Statistical Synopsis for the 2004 Fixed-Location Hydroacoustic Investigations at The Dalles Dam}

The purpose of this synopsis is to describe the statistical methods to be used in the analysis of the 2004 hydroacoustic study at The Dalles Dam. The study will estimate fish passage through the powerhouse (i.e., turbines), spillway, fish units, and sluiceway during the spring and summer smolt outmigrations. These estimates of fish passage will be used to estimate various measures of spillway and sluiceway passage performance at The Dalles Dam. Sluiceway and spill-plus-sluiceway performance measures will be used to test the effect of two alternative sluiceway operations on smolt passage at The Dalles Dam.

\section{A.1 Transducer Deployment and Sampling Scheme}

This section describes the hydroacoustic sampling schemes that were used to estimate smolt passage at the powerhouse, spillway, sluiceway, and fish units at The Dalles Dam.

\section{A.1.1 Sampling at Main Units and Fish Units at Powerhouse}

The Dalles powerhouse has 22 main turbine units, each with three turbine intake slots, and two fish units, each with two intake slots. Table A.1 summarizes the transducer deployment and the post hoc grouping of the turbine units into statistical strata.

The selected intake slots were sampled 24 hrs daily throughout the study period. Within an hour at an intake slot, fish passage was systematically sampled over time. The sampling effort within an hour at the various intake slots is summarized below:

\begin{tabular}{cc}
\hline Turbine Units & Sampling Effort \\
\hline $1,5,8-22$ & 101 -min samples $/ \mathrm{hr}$ \\
\hline 2 & 601 -min samples $/ \mathrm{hr}$ \\
F1 & 101 -min samples $/ \mathrm{hr}$ \\
\hline
\end{tabular}


Table A 1. Summary of transducer deployment at the main turbine units 1-22 and fish unit F1-F2 at The Dalles Dam in 2004 . The number of intakes sampled per unit is given, along with the post-hoc grouping of units into statistical strata and the number of intakes sampled per stratum.

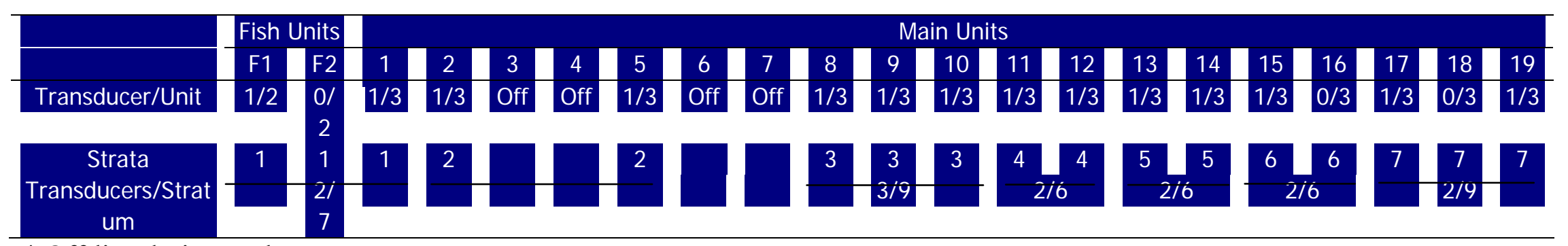

* Off-line during study

\begin{tabular}{c|c|c|c}
\hline & \multicolumn{3}{|c}{ Main Units } \\
\hline & 20 & 21 & 22 \\
\hline Transducer/Unit & $1 / 3$ & $1 / 3$ & $1 / 3$ \\
Strata & 8 & 8 & 8 \\
Transducers/Stratum & & $2 / 9$ & \\
\hline
\end{tabular}




\section{A.1.2 Sampling at Spillway}

The Dalles Dam has 23 spillbays within the spillway. During 2004, only Spillbays 1-6 are scheduled to be open during the study period. At Spillbays 1-4 and 6, a single transducer was randomly located across the breadth of the opening (i.e., north, middle, south) to monitor fish passage. At Spillbay 5 , three transducers were located across the breadth of the opening (i.e., north, middle, south). Hence, six of six operational spillbays were monitored during the study. Hydroacoustic monitoring was conducted 24 hours daily throughout the study. Within an hour at a spillbay, fish passage was systematically sampled over time. The within-hour sampling effort at all transducer locations was 151 -min samples/hr.

\section{A.1.3 Sampling at Sluiceway}

In 2004, the three sluice gates each at Main Units 1 and 18 were used to pass fish. Within each gate, a pair of horizontal-looking split beams were deployed. Hydroacoustic monitoring was conducted 24 hours daily through the study. Within an hour, fish passage was systematically sampled over time. The within-hour sampling effort was 10 1-min samples/hr at each transducer.

\section{A.2 Estimating Fish Passage}

The following sections describe how the estimates of smolt passage was to be calculated at the various locations at The Dalles Dam.

\section{A.2.1 Powerhouse Passage}

The sampling at The Dalles powerhouse turbines can be envisioned as a stratified two-stage sampling program. Constructing spatial strata by combining adjacent turbine units; the first step was the random sampling of turbine intake slots within adjacent turbine units. Table A.1 summarizes the eight8 spatial strata constructed and the numbers of intake slots sampled per stratum. The second step was envisioned as stratified random sampling of within-intake hours.

The estimator of total turbine passage over the course of D days can be expressed as follows:

$$
\hat{T}=\sum_{i=1}^{D} \sum_{j=1}^{24} \sum_{k=1}^{K}\left[\frac{A_{k}}{a_{k}}\left[\sum_{l=1}^{a_{k}} \hat{T}_{i j k l}\right]\right]
$$

where

$\hat{T}_{i j k l}=$ estimated fish passage in the lth intake slot $\left(l=1, \quad, a_{k}\right)$ within the kth turbine stratum

$(k=1, K)$ during the jth hour $(j=1,, 24)$ on the ith day $(i=1,, D)$;

$a_{k}=$ number of intake slots sampled in the kth turbine stratum $(k=1, K)$;

$A_{k}=$ total number of intake slots within the kth turbine stratum $(k=1, K)$;

$K=$ number of turbine strata created (nominally $K=8$ ). 
The estimator of $\hat{T}_{i j k l}$ is based on the assumption of simple random sampling within a slot-hour, in which case

$$
\hat{T}_{i j k l}=\frac{B_{k l}}{b_{k l}} \sum_{g=1}^{b_{k l}} w_{i j k l g}
$$

where

$W_{i j k l g}=$ expanded fish passage in the gth sampling unit $\left(g=1,, b_{i j k l}\right)$ in the lth intake slot $\left(l=1, \quad, a_{k}\right)$ within the kth turbine stratum $(k=1, K)$ during the jth hour $(j=1,, 24)$ on the ith day $(i=1, \quad, D)$;

$b_{k l}=$ number of sampling units per hour actually observed in the lth intake slot $\left(l=1, \quad, a_{k}\right)$ within the kth turbine stratum $(k=1, K)$;

$B_{k l}=$ total number of possible sampling units per hour within the lth intake slot $\left(l=1, \quad, a_{k}\right)$ within the kth turbine stratum $(k=1, K)$.

Nominally, $B_{k l}=60$ for all $k$ and $l$, and $b_{k l}=10$ or 60 , depending on location.

Combining Equations (1) and (2), the estimator for total powerhouse passage can be written as

$$
\hat{T}=\sum_{i=1}^{D} \sum_{j=1}^{24} \sum_{k=1}^{K}\left[\frac{A_{k}}{a_{k}} \sum_{l=1}^{a_{k}} \frac{B_{k l}}{b_{k l}} \sum_{g=1}^{b_{k l}} w_{i j k \mathrm{lg}}\right]
$$

The variance of $\hat{T}$ can then be estimated by the formula

$$
\operatorname{Var}(\hat{T})=\sum_{i=1}^{D} \sum_{j=1}^{24} \sum_{k=1}^{K}\left[\frac{A_{k}^{2}\left(1-\frac{a_{k}}{A_{k}}\right) s_{\hat{T}_{i j k}}^{2}}{a_{k}}+\frac{A_{k} \sum_{l=1}^{a_{k}} \operatorname{Var}\left(\hat{T}_{i j k l}\right)}{a_{k}}\right]
$$

where

$$
\begin{aligned}
& s_{\hat{T}_{i j k}}^{2}=\frac{\sum_{l=1}^{a_{k}}\left(\hat{T}_{i j k l}-\hat{\bar{T}}_{i j k}\right)^{2}}{\left(a_{k}-1\right)}, \\
& \hat{\bar{T}}_{i j k}=\frac{1}{a_{k}} \sum_{l=1}^{a_{k}} \hat{T}_{i j k l},
\end{aligned}
$$

and where for turbine units $1,5,8-22$, and $\mathrm{F} 1$, 


$$
\begin{aligned}
\operatorname{Var}\left(\hat{T}_{i j k l}\right) & =\frac{B_{k l}^{2}\left(1-\frac{b_{k l}}{B_{k l}}\right) s_{w_{i j k l}^{2}}^{2}}{b_{k l}}, \\
s_{w_{i j k l}}^{2} & =\frac{\sum_{g=1}^{b_{k l}}\left(w_{i j k l g}-\bar{w}_{i j k l}\right)}{\left(b_{k l}-1\right)}, \\
\bar{w}_{i j k l} & =\frac{1}{b_{k l}} \sum_{g=1}^{b_{k l}} w_{i j k l g} \cdot
\end{aligned}
$$

For turbine unit 2, sampling was 60 of $60 \mathrm{~min} / \mathrm{hr}$. Although the entire hour is continuously sampled, fish counts must still be expanded from the ensonified cone. Hence, there is measurement error in estimating $T_{i j k l}$ that needs to be quantified. To estimate this variance, it will be assumed that fish passage is Poissondistributed over very short intervals of time (i.e., successive 1-min intervals), in which case, the estimated passage numbers have as their distributional properties

$$
\begin{aligned}
\operatorname{Var}\left(\hat{w}_{i j k l g}\right) & =\sigma_{w_{i k l g}}^{2}+\overline{\operatorname{Var}\left(\hat{w}_{i j k l g} \mid w_{i j k l g}\right)} \\
& =\mu_{w_{i j k l g}}+\overline{\operatorname{Var}\left(\hat{w}_{i j k l g} \mid w_{i j k l g}\right)},
\end{aligned}
$$

leading to the variance estimator,

$$
\overline{\operatorname{Var}\left(\hat{w}_{i j k l g} \mid w_{i j k l g}\right)}=s_{w_{i j k l g}}^{2}-\mu_{w_{i j k l}} .
$$

This estimate of measurement error can then be calculated as follows:

$$
\overline{\operatorname{Var}\left(\hat{w}_{i j k l g} \mid w_{i j k l g}\right)}=\left[\frac{\left(w_{i j k l g}-w_{i j k l g+1}\right)^{2}}{2}-\frac{\left(w_{i j k l g}+w_{i j k l g+1}\right)}{2}\right] \text {. }
$$

The variance of $\hat{T}_{i j k l}$ can then be estimated by the quantity

$$
\operatorname{Var}\left(\hat{T}_{i j k l}\right)=\left[\left(\frac{60}{59}\right) \sum_{k=1}^{59}\left[\frac{\left(w_{i j k l g}-w_{i j k l g+1}\right)^{2}}{2}-\frac{\left(w_{i j k l g}+w_{i j k l g+1}\right)}{2}\right]\right] .
$$

\section{A.2.2 Spillway Passage}

The sampling at The Dalles spillways 1-4 and 6 can be envisioned as stratified random sampling within spillbay-hours, in which case, total spillway passage over $D$ days can be estimated by the formula

$$
S P_{1}=\sum_{i=1}^{D} \sum_{j=1}^{24} \sum_{k=1}^{5}\left[\frac{C_{i j k}}{C_{i j k}} \sum_{l=1}^{c_{i j k}} X_{i j k l}\right]
$$


where

$X_{i j k l}=$ expanded fish passage in the lth sampling interval $\left(l=1, \quad, C_{i j k}\right)$ during the $j$ th hour $(j=1,, 24)$ at the $k$ th spillbay $(k=1,, 15)$ on the ith day $(i=1,, D)$; $C_{i j k}=$ total number of possible sampling units within the $j$ th hour $(j=1,, 24)$ at the $k$ th spillbay $(k=1,, 15)$ on the $i$ th day $(i=1, \quad, D)$;

$C_{i j k}=$ number of sampling units actually observed within the $j$ th hour $(j=1,24)$ at the $k$ th spillbay $(k=1,, 15)$ on the $i$ th day $(i=1, \quad, D)$.

Nominally, $C_{i j k}=60$ and $c_{i j k}=15$ for all $i j k$.

At spillway \#5, the sampling can be envisioned as a two-way stratified random sampling scheme within-hour and within-horizontal position. The three transducer locations produce 3 horizontal strata that can be sampled independently. Hence, the estimate of total passage over $D$ days at spillway 5 can be estimated by the formula

$$
S P_{2}=\sum_{i=1}^{D} \sum_{j=1}^{24} \sum_{k=1}^{3} \frac{C_{i j k}^{\prime}}{C_{i j k}^{\prime}} \sum_{l=1}^{c_{i j k}^{\prime}} x_{i j k l}^{\prime} .
$$

where

$x_{i j k l}^{\prime}=$ expanded fish passage in the lth sampling interval $\left(l=1, \quad, c_{i j k}^{\prime}\right)$ during the $j$ th hour $(j=1, \quad, 24)$ at the $k$ th intraspillbay location $(k=1,, 15)$ on the $i$ th day

$(i=1, \quad, D)$;

$C_{i j k}^{\prime}=$ total number of possible sampling units within the $j$ th hour $(j=1,, 24)$ at the $k$ th intraspillbay location $(k=1,, 15)$ on the ith day $(i=1, \quad, D)$;

$c_{i j k}^{\prime}=$ number of sampling units actually observed within the $j$ th hour $(j=1,, 24)$ at the $k$ th intraspillbay location $(k=1, \quad, 15)$ on the $i$ th day $(i=1, \quad, D)$.

Nominally, $C_{i j k}^{\prime}=60$ and $c_{i j k}^{\prime} 15$ for all $i j k$.

Total spillway passage is then the sum of the estimators (7) and (8), where

$$
\mathrm{SP}=S P_{1}+S P_{2} \text {. }
$$

The variance of $S P_{1}$ can be estimated by the quantity

where

$$
\operatorname{Var}\left(S P_{1}\right)=\sum_{i=1}^{D} \sum_{j=1}^{24} \sum_{k=1}^{5}\left[\frac{C_{i j k}^{2}\left(1-\frac{C_{i j k}}{C_{i j k}}\right) S_{x_{i j k}^{2}}^{2}}{C_{i j k}}\right]
$$

$$
s_{x_{i j k}}^{2}=\frac{\sum_{l=1}^{c_{i j k}}\left(x_{i j k l}-\bar{x}_{i j k}\right)^{2}}{\left(c_{i j k}-1\right)}
$$


and where

$$
\bar{X}_{i j k}=\frac{1}{C_{i j k}} \sum_{l=1}^{c_{i j k}} X_{i j k l} .
$$

The variance of $\mathrm{SP}_{2}$ can be estimated by the quantity

$$
\operatorname{Var}\left(S P_{2}\right)=\sum_{i=1}^{D} \sum_{j=1}^{24} \sum_{k=1}^{3}\left[\frac{C_{i j k}^{\prime}\left(1-\frac{C_{i j k}^{\prime}}{C_{i j k}^{\prime}}\right) S_{x_{i j k}^{2}}^{2}}{C_{i j k}^{\prime}}\right]
$$

where

$$
s_{x_{i j k}^{\prime}}^{2}=\frac{\sum_{l=1}^{c_{i j k}^{\prime}}\left(x_{i j k l}^{\prime}-\bar{x}_{i j k}^{\prime}\right)^{2}}{\left(c_{i j k}^{\prime}-1\right)}
$$

and where

$$
\bar{X}_{i j k}^{\prime}=\frac{1}{c_{i j k}^{\prime}} \sum_{l=1}^{c_{i j k}^{\prime}} X_{i j k l}^{\prime} .
$$

The variance for $S P$ is then the sum of Eqs. (10) and (11), where

$$
\operatorname{Var}(S P)=\operatorname{Var}\left(S P_{1}\right)+\operatorname{Var}\left(S P_{2}\right)
$$

\section{A.2.3 Sluiceway Passage}

The far-field section of each horizontal-looking transducer cone will form a horizontal stratum within a sluice gate. Here, each sluiceway will be composed of three gates, each with two horizontal strata. Total sluiceway passage will then be estimated by the formula

$$
\hat{L}=\sum_{g=1}^{G} \sum_{h=1}^{D} \sum_{i=1}^{24} \sum_{j=1}^{3} \sum_{k=1}^{2}\left[\frac{N_{g h i j k}}{n_{g h i j k}} \sum_{l=1}^{n_{g h i k k}} y_{g h i j k l}\right]
$$

where

$y_{\text {ghijkl }}=$ expanded fish count in the lth sampling interval $\left(l=1, \quad, n_{\text {ghijk }}\right)$ in the $k$ th

horizontal stratum $(k=1,2)$ of the $j$ th gate $(j=1,, 3)$ in the ith hour $(i=1,, 24)$ of the $h$ th day $(h=1,, D)$ at the $g$ th sluiceway $(g=1,, G)$;

$N_{\text {ghijk }}=$ total number of possible sampling units within the $k$ th horizontal stratum

$(k=1,2)$ of the $j$ th gate $(j=1,, 3)$ in the $i$ th hour $(i=1,, 24)$ of the $h$ th day $(h=1, \quad, D)$ at the $g$ th sluiceway $(g=1,, G)$; 


$$
\begin{aligned}
& n_{\text {ghijk }}=\text { number of sampling units actually observed within the } k \text { th horizontal stratum } \\
& (k=1,2) \text { of the } j \text { th gate }(j=1,, 3) \text { of the } h \text { th day }(h=1,, D) \text { at the } g \text { th sluiceway } \\
& (g=1,, G) .
\end{aligned}
$$

Nominally, $G=2$ sluiceways and $N_{\text {ghijk }}=60$ and $n_{\text {ghijk }}=10$.

The variance of $\hat{L}$ can be estimated by the formula

$$
\operatorname{Var}(\hat{L})=\sum_{g=1}^{G} \sum_{h=1}^{D} \sum_{i=1}^{24} \sum_{j=1}^{3} \sum_{k=1}^{2}\left[\frac{N_{g h i k}^{2}\left(1-\frac{n_{\text {ghijk }}}{N_{\text {ghijk }}}\right)}{n_{\text {ghijk }}} s_{y_{g h i j k}}^{2}\right]
$$

where

$$
s_{y_{g h i j k}}^{2}=\frac{\sum_{l=1}^{n_{\text {ghijk }}}\left(y_{\text {ghijkl }}-\bar{y}_{\text {ghijk }}\right)^{2}}{\left(n_{\text {ghijk }}-1\right)}
$$

and where

$$
\bar{y}_{g h i j k}=\frac{\sum_{l=1}^{n_{g h i j k}} y_{g h i j k l}}{n_{g h i j k l}} .
$$

\section{A.3 Estimating Passage Performance}

\section{A.3.1 Fish Passage Efficiency (FPE)}

The fish passage efficiency (FPE) at The Dalles Dam will be estimated by the quotient

$$
F P E=\frac{S P+L}{S P+L+T}
$$

where

$$
\begin{aligned}
& S P=\text { estimated fish passage through the spillway, } \\
& \hat{L}=\text { estimated fish passage through the sluiceway, } \\
& T=\text { estimated fish passage through the turbine units (including the fish units), }
\end{aligned}
$$

where the numerator is the estimated spillway and sluiceway passage and the denominator is the total project passage. The estimate of FPE can alternatively be expressed as

$$
F P E=\frac{G}{G+U}
$$

where 


$$
\begin{aligned}
& G=S P+L, \\
& U=T .
\end{aligned}
$$

The variance of FPE can then be expressed as

$$
\operatorname{Var}(F P E)=F P E^{2}(1-F P E)^{2}\left[\frac{\operatorname{Var}(G)}{G^{2}}+\frac{\operatorname{Var}(U)}{U^{2}}\right]
$$

and where

$$
\begin{aligned}
& \operatorname{Var}(G)=\operatorname{Var}(S P)+\operatorname{Var}(L), \\
& \operatorname{Var}(U)=\operatorname{Var}(T) .
\end{aligned}
$$

\section{A.3.2 Spill Efficiency (SPY)}

Spill efficiency (SPY) at The Dalles Dam will be estimated by the quotient

$$
S P Y=\frac{S P}{S P+L+T}
$$

where the numerator is the estimate of spillway passage and the denominator is the estimate of total project passage. In turn, $S P Y$ can be re-expressed as

$$
S P Y=\frac{S P}{S P+U_{1}}
$$

where

$$
U_{1}=L+T
$$

The variance of SPY can then be expressed as

$$
\operatorname{Var}(S P Y)=S P Y^{2}(1-S P Y)^{2}\left[\frac{\operatorname{Var}(S P)}{S P^{2}}+\frac{\operatorname{Var}\left(U_{1}\right)}{U_{1}^{2}}\right]
$$

where

$$
\operatorname{Var}\left(U_{1}\right)=\operatorname{Var}(L)+\operatorname{Var}(T) .
$$

\section{A.3.3 Sluiceway Efficiency (SLY)}

Sluiceway efficiency (SLY) at The Dalles Dam will be estimated by the quotient

$$
S L Y=\frac{\hat{L}}{S P+\hat{L}+\hat{T}},
$$

where the numerator is the estimate of sluiceway passage and the denominator is the estimate of total project passage. In turn, $S L Y$ can be expressed as

$$
S L Y=\frac{\hat{L}}{\hat{L}+\hat{U}_{2}}
$$


where

$$
\hat{U}_{2}=S P+\hat{T} .
$$

The variance of $S L Y$ can then be expressed as

$$
\operatorname{Var}(S L Y)=S L Y^{2}(1-S L Y)^{2}\left[\frac{\operatorname{Var}(\hat{L})}{\hat{L}^{2}}+\frac{\operatorname{Var}\left(\hat{U}_{2}\right)}{\hat{U}_{2}^{2}}\right]
$$

where

$$
\operatorname{Var}\left(\hat{U}_{2}\right)=\operatorname{Var}(S P)+\operatorname{Var}(\hat{T})
$$

\section{A.3.4 Conditional Sluiceway Efficiency (SLYphs)}

The conditional probability of a smolt going through the sluiceway given it is passing through the powerhouse can be estimated by the quotient

$$
\text { SLYphs }=\frac{\hat{L}}{\hat{L}+T} .
$$

The variance of SLYphs can then be expressed as follows

$$
\operatorname{Var}(\text { SLYphs })=\operatorname{SLYphs}^{2}(1-\text { SLYphs })^{2}\left[\frac{\operatorname{Var}(\hat{L})}{\hat{L}^{2}}+\frac{\operatorname{Var}(\hat{T})}{\hat{T}^{2}}\right] \text {. }
$$

\section{A.3.5 Sluiceway-to-Turbine Passage}

Another localized measure of sluiceway efficiency is relative to fish passage through a particular turbine unit

$$
S L Y_{k}=\frac{\hat{L}_{k}}{\hat{L}_{k}+\hat{T}_{k}}
$$

where

$\hat{L}_{k}=$ estimated fish passage through the $k$ th sluiceway ( $k=1$ or 18$)$,

$\hat{T}_{k}=$ estimated fish passage through the $k$ th turbine units $(k=1$ or 18$)$.

The variance of $L Y_{k}$ can be estimated by

$$
\operatorname{Var}\left(L Y_{k}\right)=L Y_{k}^{2}\left(1-L Y_{k}\right)^{2}\left[\frac{\operatorname{Var}\left(\hat{L}_{k}\right)}{\hat{L}_{k}^{2}}+\frac{\operatorname{Var}\left(\hat{T}_{k}\right)}{\hat{T}_{k}^{2}}\right] .
$$

For a specific passage estimate at a turbine, the estimator is as follows

$$
\hat{T}_{k}=\sum_{i=1}^{D} \sum_{j=1}^{24}\left[\frac{A_{k}}{a_{k}} \sum_{l=1}^{a k} \frac{B_{k l}}{b_{k l}} \sum_{g=1}^{b_{k l}} w_{i j k \mathrm{lg}}\right],
$$

with approximate variance estimator

$$
\operatorname{Var}\left(\hat{T}_{k}\right)=\sum_{i=1}^{D} \sum_{j=1}^{24}\left(\frac{A_{k}}{a_{k}}\right)^{2}\left[\frac{B_{k l}^{2}\left(1-\frac{b_{k l}}{B_{k l}}\right) s_{w_{i j k l}^{2}}^{2}}{b_{k l}}\right] .
$$


Nominally, $A_{k}=3, a_{k}=1$, and $B_{k l}=60$ with $b_{k l}=10$. Note variance estimator (26) will likely underestimate the true variance because no estimate of slot-to-slot variability is possible.

\section{A.3.6 Fish Passage Effectiveness (FPS)}

Fish passage effectiveness (FPS) will be estimated by the function

$$
\begin{aligned}
F P S & =\frac{\left(\frac{S P+\hat{L}}{f_{S P}+f_{L}}\right)}{\left(\frac{S P+\hat{L}+\hat{T}}{f_{S P}+f_{L}+f_{T}}\right)} \\
& =\left(\frac{f}{f_{S P}+f_{L}}\right) \cdot F P E
\end{aligned}
$$

where

$$
\begin{aligned}
& f_{S P}=\text { spillway flow volume } \\
& f_{L}=\text { sluiceway flow volume }, \\
& f_{T}=\text { turbine flow volume } \\
& f=f_{S P}+f_{L}+f_{T}
\end{aligned}
$$

The variance of FPS can be estimated by the quantity

$$
\operatorname{Var}(F P S)=\left(\frac{f}{f_{S P}+f_{L}}\right)^{2} \cdot \operatorname{Var}(F P E) .
$$

\section{A.3.7 Spill Effectiveness (SPS)}

Spill effectiveness (SPS) at The Dalles Dam will be estimated by the function

$$
S P S=\frac{\left(\frac{S P}{f_{S P}}\right)}{\left[\frac{(S P+\hat{L}+T)}{f}\right]}=\left(\frac{f}{f_{S P}}\right) \cdot S P Y .
$$

The variance of SPS can be estimated by the quantity

$$
\operatorname{Var}(S P S)=\left(\frac{f}{f_{S P}}\right)^{2} \cdot \operatorname{Var}(S P Y) .
$$

\section{A.3.8 Sluiceway Effectiveness (SLS)}

Sluiceway effectiveness (SLS) will be estimated by the function 


$$
\begin{aligned}
S L S & =\frac{\left(\frac{\hat{L}}{f_{L}}\right)}{\left[\frac{(\hat{L}+S P+T)}{f}\right]} \\
& =\left(\frac{f}{f_{L}}\right) L Y
\end{aligned}
$$

with an associated variance estimator of

$$
\operatorname{Var}(S L S)=\left(\frac{f}{f_{L}}\right)^{2} \cdot \operatorname{Var}(S L Y) .
$$

\section{A.3.9 Conditional Sluiceway Effectiveness (SLSphs)}

Conditional sluiceway effectiveness (SLSphs) will be estimated by the quantity

$$
\begin{aligned}
\text { SLSphs } & =\frac{\left(\frac{\hat{L}}{f_{L}}\right)}{\left(\frac{\hat{L}+\hat{T}}{f_{L}+f_{T}}\right)} \\
& =\left(\frac{f_{L}+f_{T}}{f_{L}}\right) \cdot S L Y .
\end{aligned}
$$

The variance of SLSphs can then be expressed as

$$
\operatorname{Var}(\text { SLSphs })=\left(\frac{f_{L}+f_{T}}{f_{L}}\right)^{2} \cdot \operatorname{Var}(S L Y) .
$$

\section{A.3.10 Relative Effectiveness of Sluiceway-to-Turbine Passage}

The relative effectiveness of the sluiceway-to-turbine effectiveness can be estimated by the quantity

$$
\begin{aligned}
S L S_{k} & =\frac{\left(\frac{\hat{L_{k}}}{f_{L_{k}}}\right)}{\left(\frac{\hat{L_{k}}+\hat{T_{k}}}{f_{L_{k}}+f_{T_{k}}}\right)} \\
& =\left(\frac{f_{L_{k}}+f_{T_{k}}}{f_{L_{k}}}\right) \cdot L Y_{k}
\end{aligned}
$$

with associated variance estimator

$$
\operatorname{Var}\left(S L S_{k}\right)=\left(\frac{f_{L_{k}}+f_{T_{k}}}{f_{L_{k}}}\right)^{2} \cdot \operatorname{Var}\left(S L Y_{k}\right)
$$


where

$$
\begin{aligned}
& f_{T_{k}}=\text { flow volume through turbine unit } k, \\
& f_{L_{k}}=\text { flow volume through sluiceway } k .
\end{aligned}
$$

\section{A.4 Test of Sluiceway Treatments}

During spring and summer, a randomized block experimental design will be performed to compare passage performance measures under two different treatment conditions. The two treatment conditions are as follows:

a. Sluice 1 only operating.

b. Sluices 1 and 18 both operating.

The summer study will consist of approximately 24 blocks, the spring study will consist of approximately 21 blocks. Each block will be two days in duration, with one day under sluiceway test condition.

The test of the effect of sluiceway treatments will be performed using a two-way ANOVA for a randomized block experimental design. The ANOVA table will be of the form depicted below:

\begin{tabular}{lclll}
\hline Source & df & SS & MS & F \\
\hline Total & $2 \mathrm{~B}$ & & & \\
Mean & 1 & & & \\
Total $_{\text {Cor }}$ & $2 \mathrm{~B}-1$ & SSTOT & & \\
Blocks $_{\text {Treatments }}$ & B-1 & SSB & & \\
Error & 1 & SST & MST & $\mathrm{F}_{1,13}=\frac{\text { MST }}{\text { MSE }}$ \\
\hline
\end{tabular}

The F-test from the ANOVA is a two-tailed test of no treatment effect. Many of the hypotheses of interest are one-tailed. The tests of significance should then be based on

$$
t_{4}=\sqrt{F_{1,4}}
$$

with the appropriate sign assigned to the $\mathrm{t}$-statistic. It is recommended that all response variables be $\ln$ transformed before the ANOVA.

Separate analyses will be performed to assess the following response variables and hypotheses:

1. FPE

$$
\begin{array}{ll}
\mathrm{H}_{\mathrm{o}}: & \mu_{1} \geq \mu_{1,18} \\
\mathrm{H}_{\mathrm{a}}: & \mu_{1}<\mu_{1,18}
\end{array}
$$


2. $S P Y$

$$
\mathrm{H}_{\mathrm{o}}: \quad \mu_{1} \leq \mu_{1,18}
$$

3. $L Y$

$$
\mathrm{H}_{\mathrm{a}}: \mu_{1}>\mu_{1,18}
$$

$\mathrm{H}_{\mathrm{a}}: \mu_{1}<\mu_{1,18}$

4. $C L Y$

$$
\mathrm{H}_{\mathrm{o}}: \quad \mu_{1} \geq \mu_{1,18}
$$

$\mathrm{H}_{\mathrm{a}}: \quad \mu_{1}<\mu_{1,18}$

5. $L Y_{k}$

$$
\mathrm{H}_{\mathrm{o}}: \quad \mu_{1} \geq \mu_{1,18}
$$

$$
\mathrm{H}_{\mathrm{a}}: \mu_{1}<\mu_{1,18}
$$

6. $F P N$

$$
\mathrm{H}_{\mathrm{o}}: \mu_{1} \geq \mu_{1,18}
$$

$$
\mathrm{H}_{\mathrm{a}}: \mu_{1}<\mu_{1,18}
$$

7. $S P N$

$$
\mathrm{H}_{\mathrm{o}}: \mu_{1} \leq \mu_{1,18}
$$

$$
\mathrm{H}_{\mathrm{a}}: \mu_{1}>\mu_{1,18}
$$

8. $L N$

$$
\mathrm{H}_{\mathrm{o}}: \quad \mu_{1} \geq \mu_{1,18}
$$

$$
\mathrm{H}_{\mathrm{a}}: \mu_{1}<\mu_{1,18}
$$

9. $C L N$

$$
\mathrm{H}_{\mathrm{o}}: \quad \mu_{1} \geq \mu_{1,18}
$$

$$
\mathrm{H}_{\mathrm{a}}: \mu_{1}<\mu_{1,18}
$$

10. $L N_{k}$

$$
\begin{array}{ll}
\mathrm{H}_{\mathrm{o}}: & \mu_{1} \leq \mu_{1,18} \\
\mathrm{H}_{\mathrm{a}}: & \mu_{1}>\mu_{1,18}
\end{array}
$$

where $\mu_{1}$ is the mean when only sluiceway \#1 is operating and $\mu_{1,18}$ is the mean when both sluiceways 1 and 18 are operating.

Additional tests will be performed to assess the effects of sluiceway 18 operations on sluiceway 1 performance. These tests will examine location-specific effects. The tests of hypotheses include the following:

$$
\begin{array}{lll}
L Y_{1} & \mathrm{H}_{\mathrm{o}}: & \mu_{1} \geq \mu_{1,18} \\
& \mathrm{H}_{\mathrm{a}}: & \mu_{1}<\mu_{1,18} \\
& & \\
L N_{1} & \mathrm{H}_{\mathrm{o}}: & \mu_{1} \geq \mu_{1,18} \\
& \mathrm{H}_{\mathrm{a}}: & \mu_{1}<\mu_{1,18} .
\end{array}
$$




\title{
Appendix B
}

\section{Directionality Analysis of the 2004 The Dalles Dam DIDSON Tracking Data}

\author{
Prepared for: \\ Gary Johnson \\ Pacific Northwest National Laboratory \\ 620 SW Fifth Avenue, Suite 810 \\ Portland, Oregon 97204 \\ Prepared by: \\ John R. Skalski \\ Jim Lady \\ Columbia Basin Research \\ School of Aquatic and Fishery Sciences \\ University of Washington \\ 1325 Fourth Avenue, Suite 1820 \\ Seattle, Washington 98101
}

26 October 2004

(Formatted and edited for consistency by G. Johnson on 12 January 2005) 
Hydroacoustic Evaluation of Juvenile Salmonid Passage at The Dalles Dam in 2004 


\section{Appendix B}

\section{Directionality Analysis of the 2004 The Dalles Dam DIDSON Tracking Data}

During spring and summer 2004, the DIDSON was used to track smolt movements in and about the sluiceways at units 1 and 18 at The Dalles Dam. The DIDSON provided two-dimensional positioning of smolts in time. For each fish track, xy coordinates were provided, along with a time stamp (t) for repeated observation as the fish moved in the vicinity of the DIDSON. Tracks with three or more observations were analyzed in this report.

The goal of the analysis was to characterize the propensity for smolts to enter the sluiceway and to compare the probability of entrainment under alternative scenarios. This analysis used minimal assumptions to estimate entrainment rates and to provide a contrast with the Markov analysis of the same data performed by John Hedgepeth.

\section{B.1 Statistical Methods}

\section{B.1.1 Track Analysis}

The series of $x, y, t$ time-space coordinates were analyzed separately for each DIDSON track. The principal axis of movement was defined as the linear vector that best characterized the primary direction of smolt movement in two-dimensional space. The vector of movement was estimated using separate linear regressions for each dimension of the form

$$
x_{i}=\alpha_{1}+\beta_{1} t_{i}
$$

and

$$
y_{i}=\alpha_{2}+\beta_{2} t_{i}
$$

where

$$
\begin{aligned}
& x_{i}=\mathrm{x} \text { coordinate (i.e., parallel to dam face) at time } t_{i}, \\
& y_{i}=\text { y coordinate (i.e., perpendicular to dam face) at time } t_{i}, \\
& t_{i}=\text { time of the } i \text { th track observation. }
\end{aligned}
$$

Hence, the principal axis of movement was defined as

$$
\left[\begin{array}{l}
x_{i} \\
y_{i}
\end{array}\right]=\left[\begin{array}{l}
\hat{\alpha}_{1}+\hat{\beta}_{1} t_{i} \\
\hat{\alpha}_{2}+\hat{\beta}_{2} t_{i}
\end{array}\right] .
$$




\section{B.1.2 Proportion of Tracks to Boundary Conditions}

The zone of ensonification about a DIDSON was envisioned as a semicircle (Figure B.1) centered about the pier nose at either turbine unit 1 or 18 . The edges of the semicircle were then subdivided into four absorption or boundary conditions, i.e., sluiceway, east, west, and forebay.

For each fish, the estimated principal axis of movement was used to project the fish track to the boundary of the semicircle. Hence, each fish track was translated to a multiple Bernoulli response of either contacting the sluiceway, east, west, or forebay location.

These projections to the boundary conditions were performed two ways. One approach was to use the entire DIDSON track. These data provided multinomial counts to later be compared under alternative sluiceway operating conditions. The other approach was to use the DIDSON tracks once they entered a zone within the semicircle (Figure B.2). These results were used to estimate the probabilities of entrainment by locale within the semicircle.

\section{B.1.3 Comparison of Sluiceway Operations}

The DIDSON data were collected and analyzed separately for spring and summer; day and night; unit 1 only, unit 18 only, or both units 1 and 18 operating simultaneously. These classifications resulted in a 2 x 2 x 3 factorial design. General linear models using a logit-link and binomial-error structure were used to compare the proportion of fish passing into the sluiceway (i.e., principal axis of movement projected into the sluiceway) under alternative conditions. Quasi-likelihood methods based on analysis of deviance (ANODEV) were used to test the main effect of season, time of day, and operational mode. A degree-of-freedom table for the ANODEV is shown in Table B.1. Interaction plots and 95\% confidence intervals were calculated to illustrate the observed patterns in the entrainment data.

Table B.1. Example Degree of Freedom Table for Analysis of Deviance

\begin{tabular}{|l|c|}
\hline \multicolumn{1}{|c|}{ Source } & DF \\
\hline Total $_{\text {Cor }}$ & 11 \\
\hline Season & 1 \\
\hline Day/Night & 1 \\
\hline Operations & 2 \\
\hline Error & 7 \\
\hline
\end{tabular}




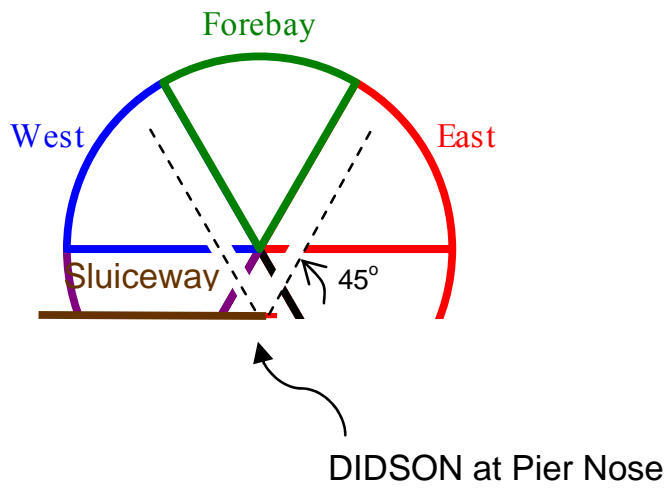

Figure B.1. Schematic of ensonified zone about a DIDSON pier-nose location, subdividing the edges of the field into sluiceway, east, west, and forebay locations.

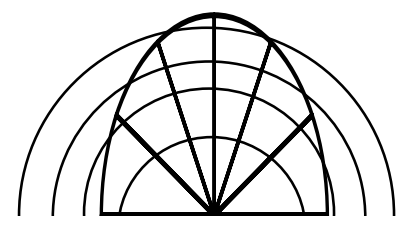

Figure B.2. Schematic of how the ensonified semicircle about the DIDSON was subdivided into separate cells (i.e., wedges) to estimate the localized probabilities of entrainment.

\section{B.1.4 Mapping Zones of Entrainment}

Using the proportions of fish entrained in the sluiceway by location (Figure B.2), contour maps of the zone of entrainment were constructed using a contouring routine in S-Plus. The various contours map the probabilities of entrainment radiating away from the sluiceway entrance. The contours provide a visual representation of the expected percentages of entrainment through the sluiceway as a function of forebay location. Zones of entrainment can be visually compared between spring/summer, day/night, or operational modes. 


\section{B.2 Results}

\section{B.2.1 Quantitative Comparison of the Probabilities of Entrainment}

The calculated principal axis of movement (PAM) is an index or simplification of the complex movement patterns of a fish. Its purpose is to characterize the general direction of movement and project that trend to the boundaries of the DIDSON semicircle. The key assumption in using PAM is that fish continue in the same general direction after leaving the DIDSON observations as when observed. While this assumption cannot be confirmed, it need not be absolutely true to compare movement between sluiceway operations. As long as any projection bias is constant, relative movements between sluiceway operations can be compared, although the actual values for the estimated entrainment proportion may be biased.

Table B.2 summarizes the counts of fish projected into the four boundary conditions for each of the 12 monitoring conditions. Table B.3 reports the observed proportions of fish with projections into the four boundary conditions for each of the 12 monitoring conditions. Using the marginals for entering the sluiceway, generalized linear model (GLM) analysis assessed the effects of day/night, spring/summer, and operating conditions on entrance efficiency. The resulting ANODEV table and corresponding F-tests are presented in Table B.4. No significant difference in sluiceway entrance was observed between operating conditions $(\mathrm{P}=0.3959)$, but differences were observed between night/day $(\mathrm{P}=0.0145)$ and spring/summer $(\mathrm{P}=0.0256)$. Table B.4 summarizes the proportions of PAMs projected into the sluiceway by season and time of day. Spring-night conditions had the highest sluiceway use projections $(0.3222, \mathrm{SE}=0.0246)$, while summer-day conditions had the lowest projections $(0.1547, \mathrm{SE}=0.0103)$.

Table B.2. Counts of DIDSON tracks where principal axis of movement (PAM) contacted the sluiceway, east, west, or forebay boundaries (Figure B1) under different monitoring conditions.

\begin{tabular}{|l|l|l|r|r|r|r|c|}
\hline Season & Day/Night & Operations & East & Forebay & Sluiceway & West & Total \\
\hline Spring & Day & MU18 & 17 & 30 & 41 & 91 & 179 \\
\hline Spring & Night & MU18 & 11 & 16 & 39 & 82 & 148 \\
\hline Spring & Day & MU1 only & 4 & 38 & 46 & 122 & 210 \\
\hline Spring & Night & MU1 only & 10 & 6 & 35 & 51 & 102 \\
\hline Spring & Day & MU1 both & 7 & 50 & 75 & 169 & 301 \\
\hline Spring & Night & MU1 both & 10 & 14 & 42 & 44 & 110 \\
\hline Summer & Day & MU18 & 31 & 54 & 66 & 156 & 307 \\
\hline Summer & Night & MU18 & 13 & 23 & 57 & 156 & 249 \\
\hline Summer & Day & MU1 only & 34 & 116 & 63 & 219 & 432 \\
\hline Summer & Night & MU1 only & 7 & 8 & 39 & 52 & 106 \\
\hline Summer & Day & MU1 both & 22 & 105 & 63 & 312 & 502 \\
\hline Summer & Night & MU1 both & 16 & 31 & 34 & 94 & 175 \\
\hline MU1 both
\end{tabular}


Table B.3. Percentages of DIDSON tracks where principal axis of movement (PAM) contacted the sluiceway, east, west, or forebay boundaries (Figure B1) under different monitoring conditions.

\begin{tabular}{|l|l|l|l|l|l|l|}
\hline \multicolumn{1}{|c|}{ Season } & \multicolumn{1}{|c|}{ Day/Night } & $\begin{array}{c}\text { Sample } \\
\text { Locations and } \\
\text { Operation }\end{array}$ & East & Forebay & Sluiceway & West \\
\hline Spring & Day & MU18 & 0.0950 & 0.1676 & 0.2291 & 0.5084 \\
\hline Spring & Night & MU18 & 0.0743 & 0.1081 & 0.2635 & 0.5541 \\
\hline Spring & Day & MU1 only & 0.0190 & 0.1810 & 0.2190 & 0.5810 \\
\hline Spring & Night & MU1 only & 0.0980 & 0.0588 & 0.3431 & 0.5000 \\
\hline Spring & Day & MU1 both & 0.0233 & 0.1661 & 0.2492 & 0.5615 \\
\hline Spring & Night & MU1 both & 0.0909 & 0.1273 & 0.3818 & 0.4000 \\
\hline Summer & Day & MU18 & 0.1010 & 0.1759 & 0.2150 & 0.5081 \\
\hline Summer & Night & MU18 & 0.0522 & 0.0924 & 0.2289 & 0.6265 \\
\hline Summer & Day & MU1 only & 0.0787 & 0.2685 & 0.1458 & 0.5069 \\
\hline Summer & Night & MU1 only & 0.0660 & 0.0755 & 0.3679 & 0.4906 \\
\hline Summer & Day & MU1 both & 0.0438 & 0.2092 & 0.1255 & 0.6215 \\
\hline Summer & Night & MU1 both & 0.0914 & 0.1771 & 0.1943 & 0.5371 \\
\hline
\end{tabular}

\section{B.2.2 Graphical Comparisons of Entrainment Projections}

The GLM analysis suggested differences between day/night and spring/summer in the proportions of PAMs into the sluiceway. Gridding the zone of ensonification (Figure B.2), the proportions of PAMs projected into the sluiceway by locations were computed for each of the four day/night, spring/summer scenarios (Figures B.3-B.6). These observed projections were then contoured to provide $2 \mathrm{D}$ and $3 \mathrm{D}$ plots of zones of entrainment in the vicinity of the sluiceway. For each scenario, raw counts, proportions, 2D-contour maps, and two alternative 3D-contour perspectives are provided. In estimating the proportions, neighboring cell counts were pooled to produce minimum counts of 10 or more in most circumstances. The same spatial pattern of pooled cells were used in all four scenarios to enhance comparability between figures. For the $3 \mathrm{D}$ plots, one perspective is from the forebay looking in toward the dams; the second perspective is from the dam looking out towards the forebay. In all cases, the fraction of PAMs projected into the sluiceway is greatest in the vicinity of the opening.

Table B.4. The ANODEV table testing the main effects of day/night, season, and operating conditions on the proportions of PAMs projected into the sluiceway.

\begin{tabular}{|c|r|r|r|r|c|}
\hline Source & df & \multicolumn{1}{c|}{ DEV } & MDEV & F-test & P-test \\
\hline Total $_{\text {Cor }}$ & 11 & 82.6878 & 7.5171 & & \\
\hline Day/Night & 1 & 31.3034 & 31.3034 & 10.4206 & 0.0145 \\
\hline Season & 1 & 23.9825 & 23.9825 & 7.9836 & 0.0256 \\
\hline Operations & 2 & 6.3740 & 3.1870 & 1.0609 & 0.3959 \\
\hline Residual & 7 & 21.0279 & 3.0040 & & \\
\hline
\end{tabular}


Table B.5. Proportions of PAMs projected into the sluiceway under the conditions of day/night and season at The Dalles Dam in 2004.

\begin{tabular}{|l|c|c|c|}
\hline \multicolumn{1}{|c|}{ Conditions } & Sample Size & Proportions & SE \\
\hline Spring - Day & 690 & 0.2348 & 0.0161 \\
\hline Spring - Night & 360 & 0.3222 & 0.0246 \\
\hline Summer - Day & 1241 & 0.1547 & 0.0103 \\
\hline Summer - Night & 530 & 0.2453 & 0.0187 \\
\hline
\end{tabular}


a. Raw counts by location

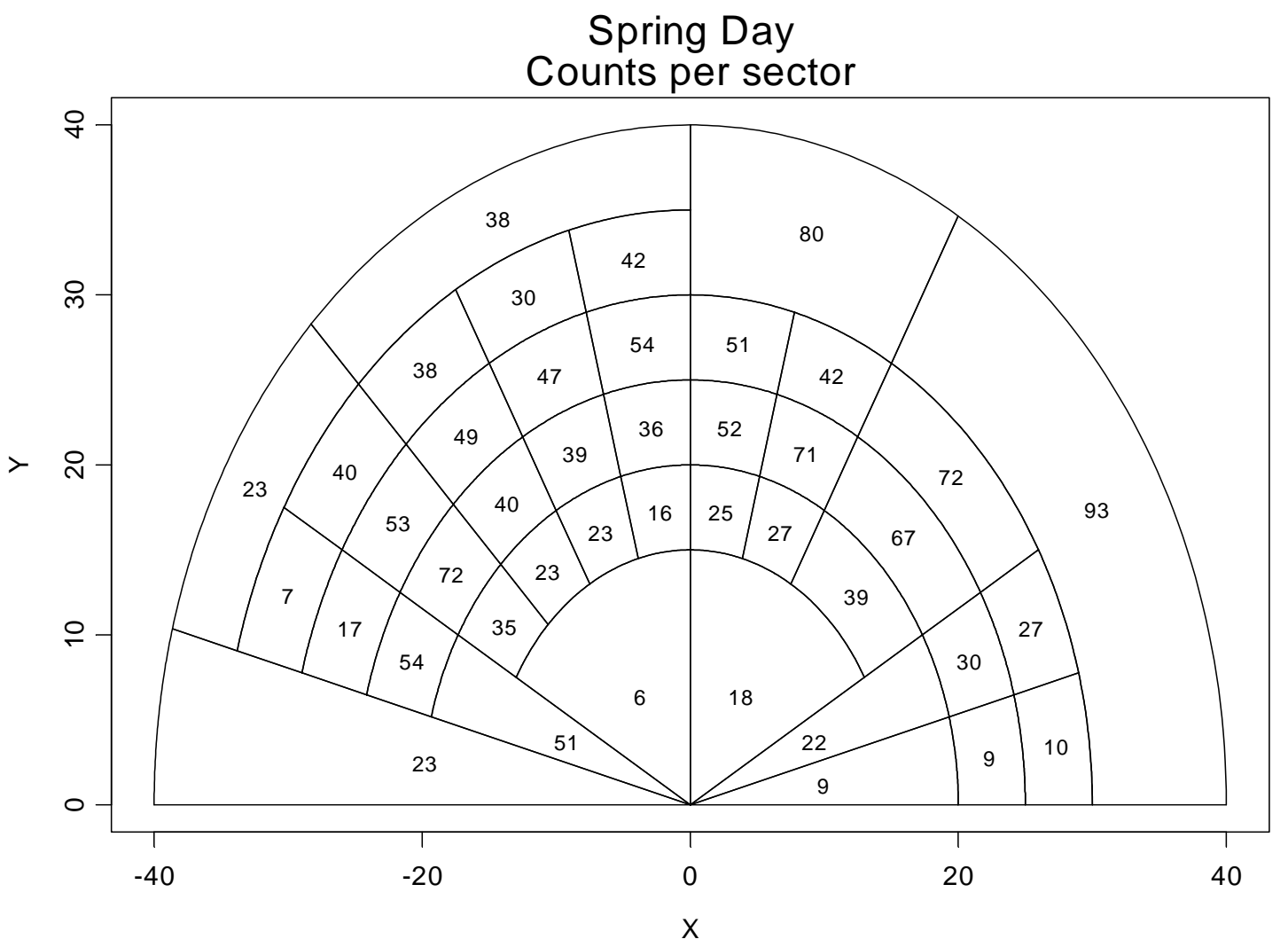

b. Observed proportions by location

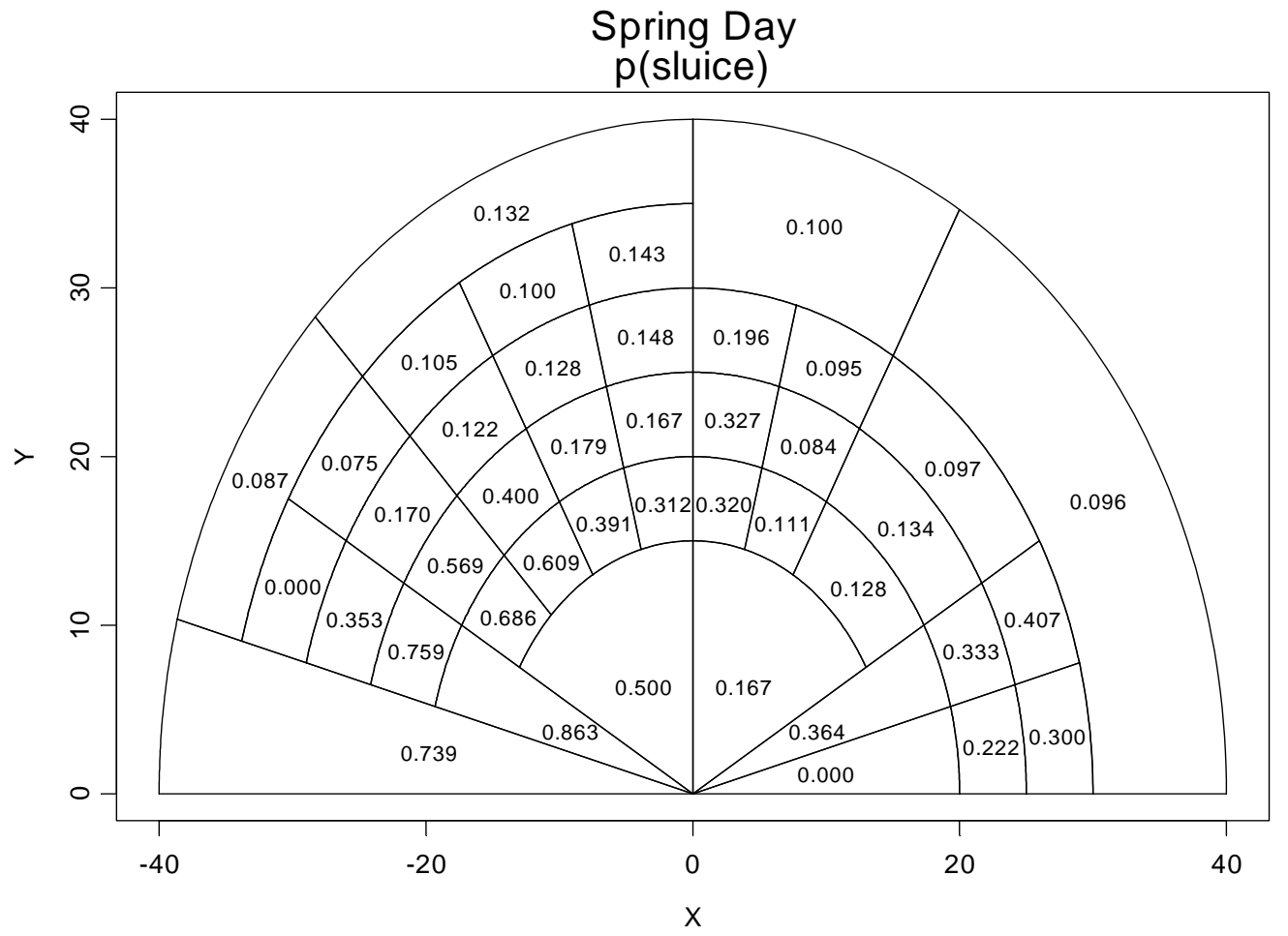

B.7 
c. $2 \mathrm{D}$ contour plot

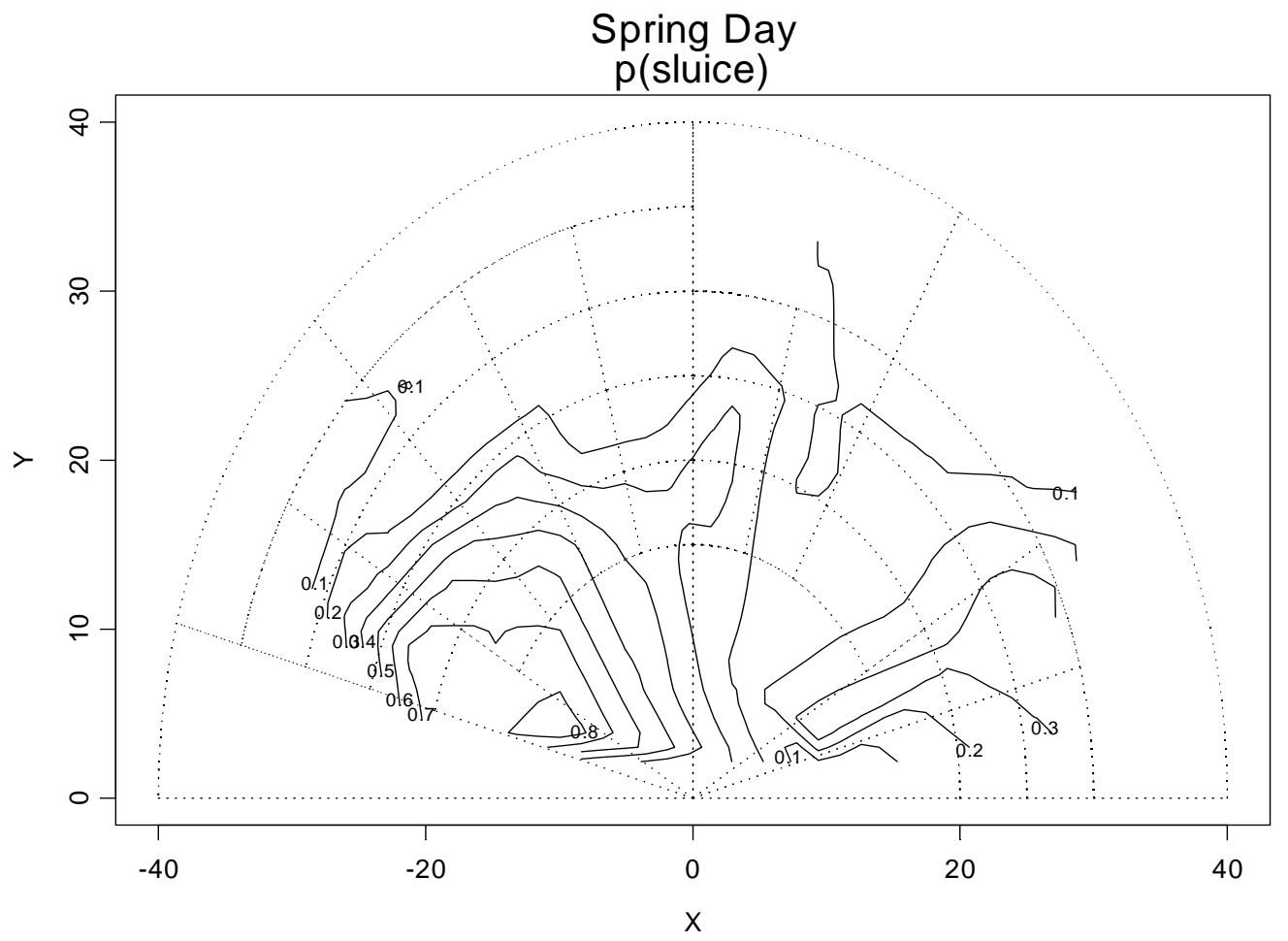

d. $3 \mathrm{D}$ contour plot looking toward the dam from the forebay

Spring Day

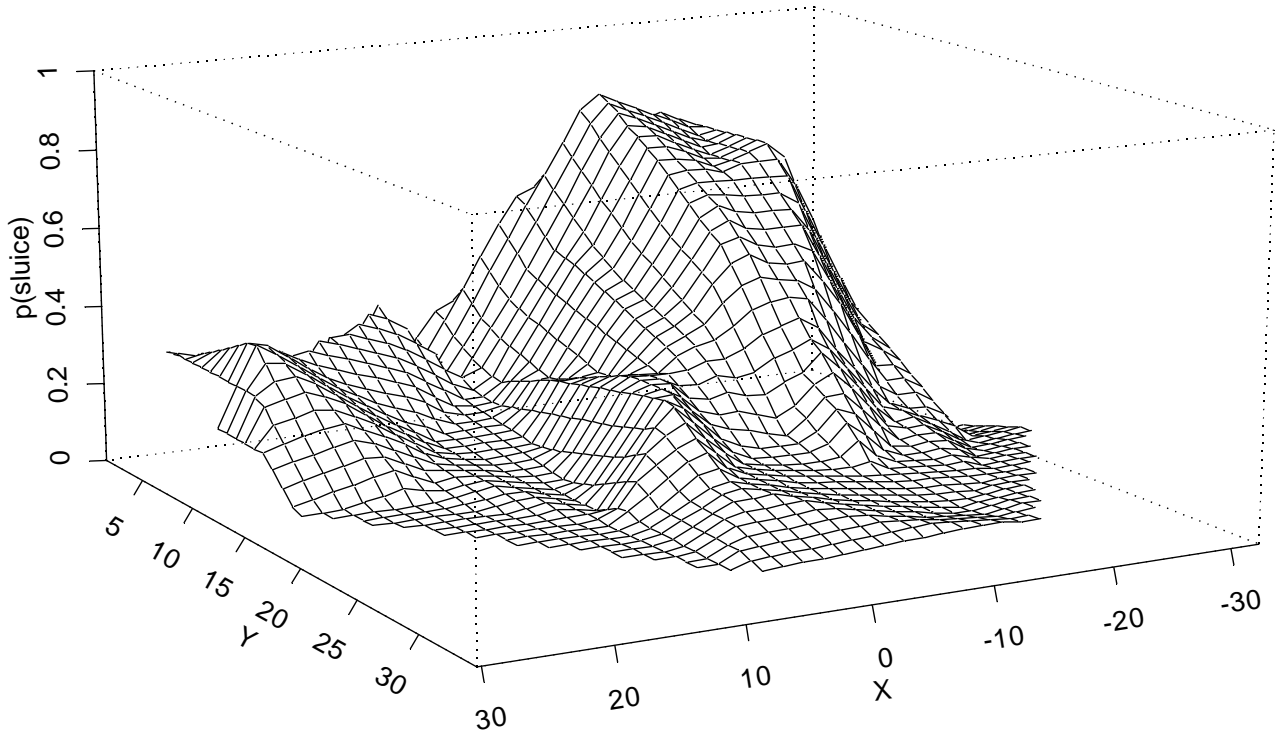


e. 3D contour plot looking towards the forebay from the dam

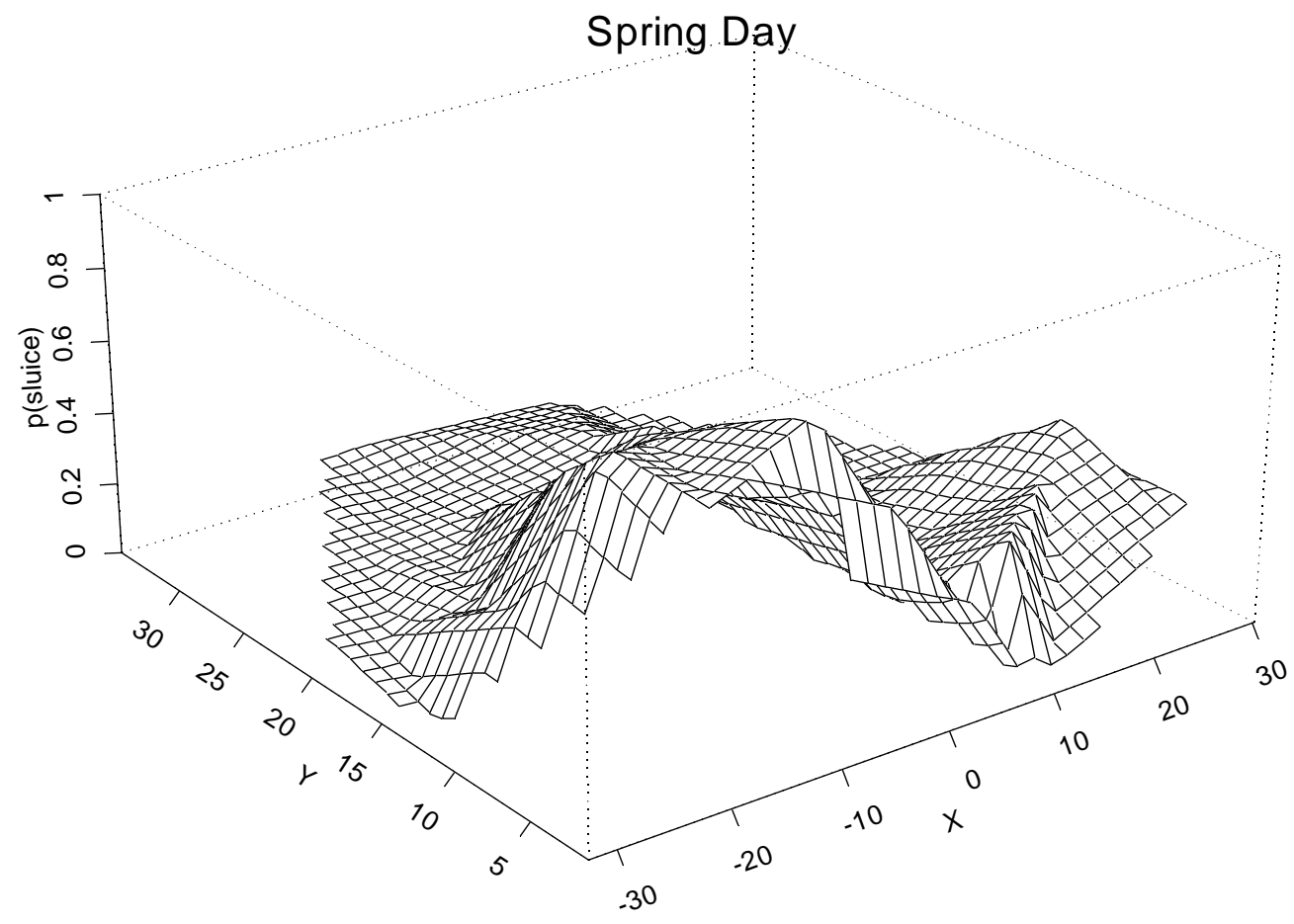

Figure B.3. Graphical plots of the proportions of PAMs projected into the sluiceway as a function of fish forebay location for the spring-day scenario at The Dalles Dam in 2004. Subplot (a) raw counts by location, (b) observed proportions by location, (c) 2D contour plot, (d) 3D contour plot looking toward the dam from the forebay, and (e) 3D contour plot looking toward the forebay from the dam. 
a. Raw counts by location

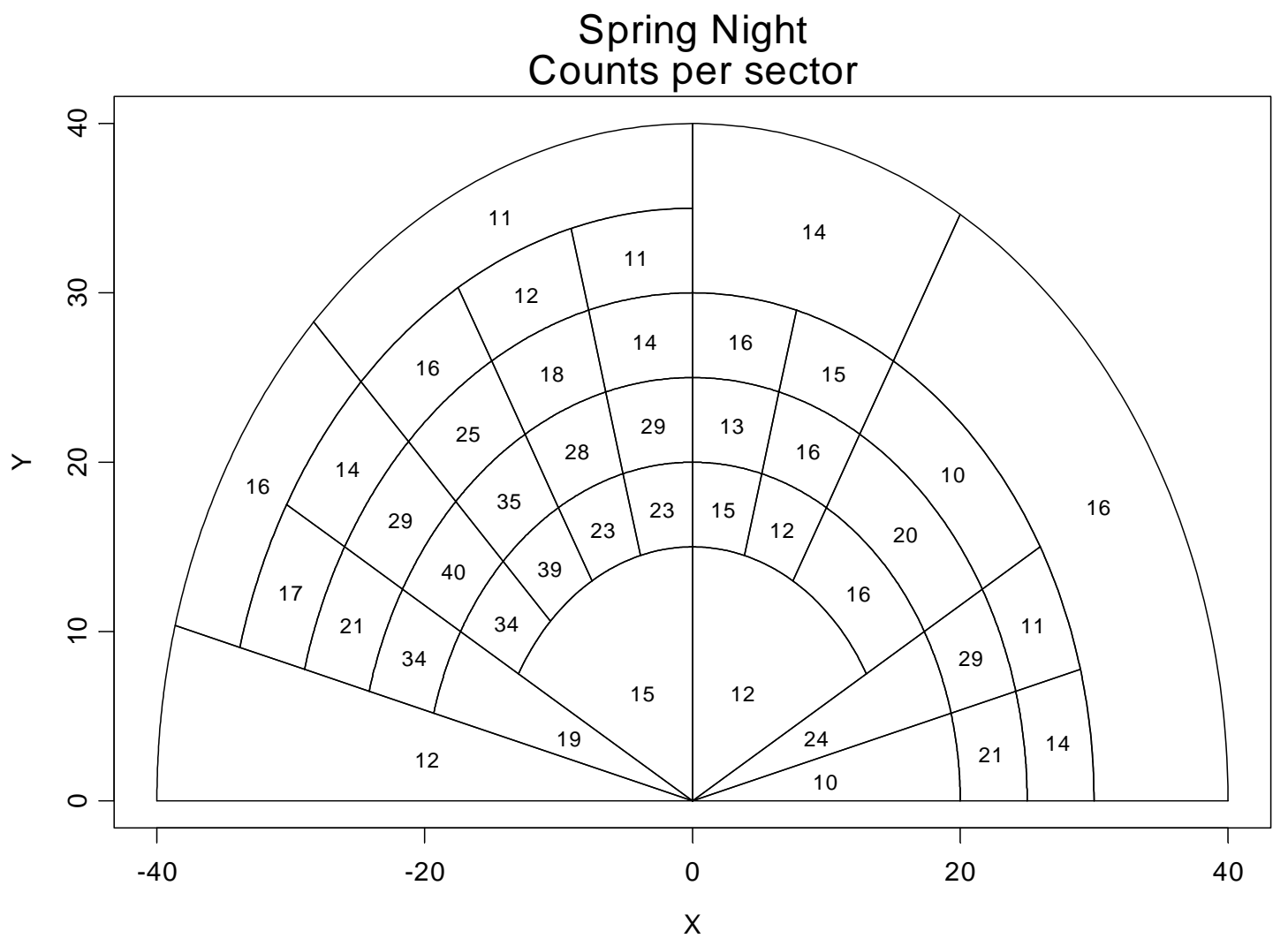

b. Observed proportions by location

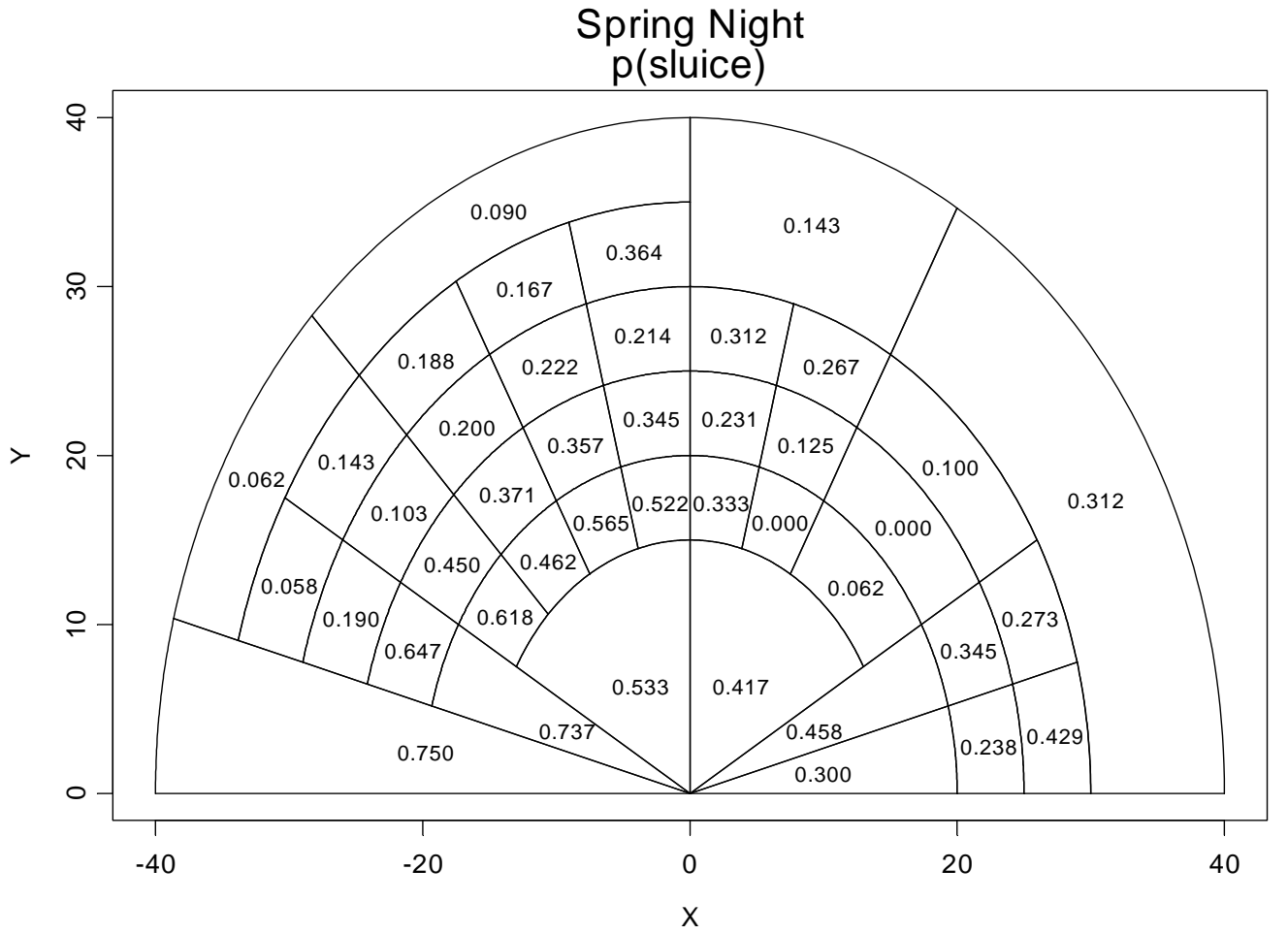


c. $2 \mathrm{D}$ contour plot

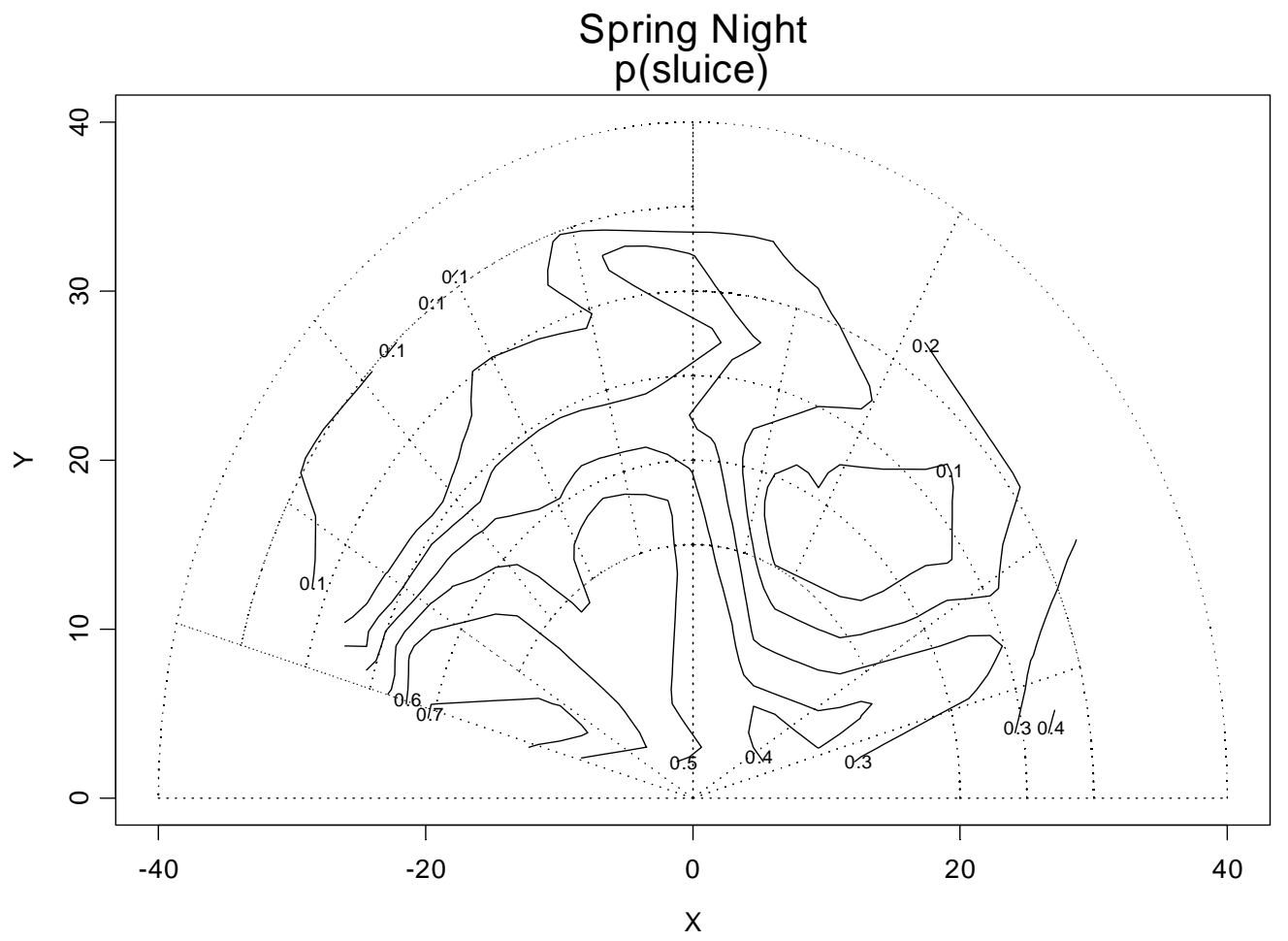

d. $3 \mathrm{D}$ contour plot looking toward the dam from the forebay

Spring Night

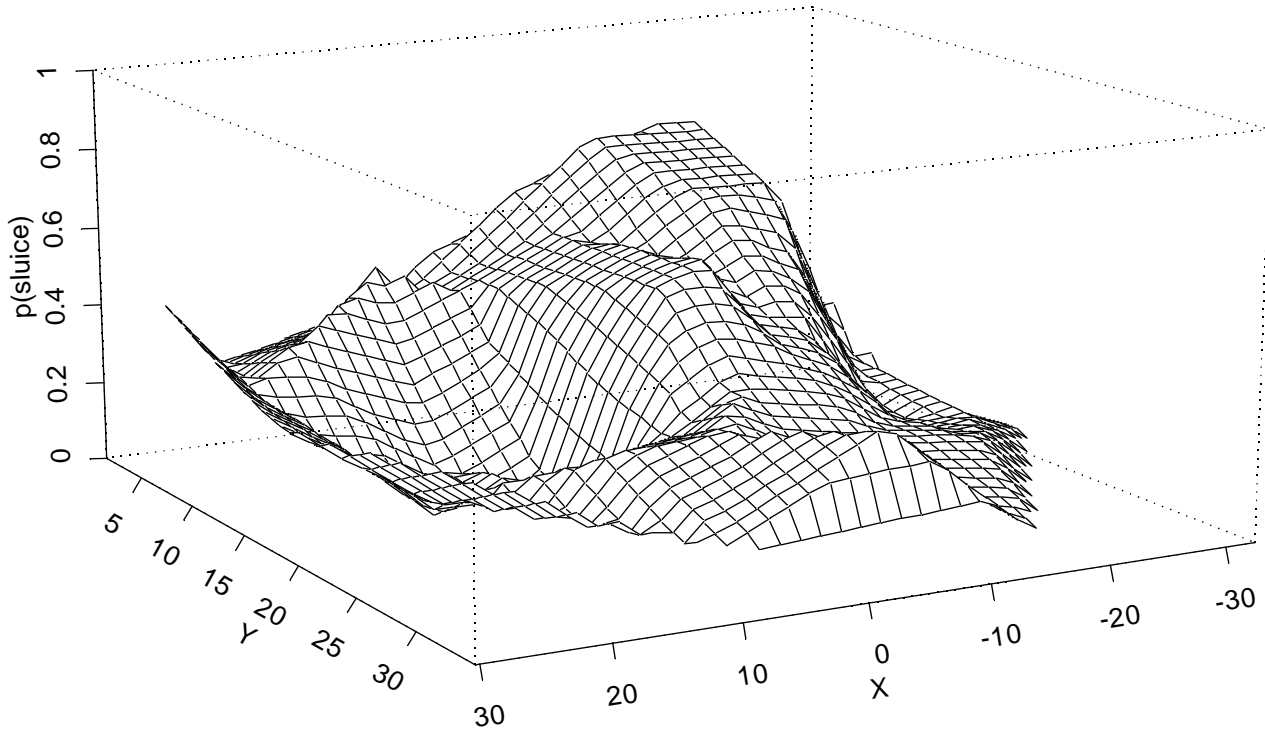


e. 3D contour plot looking towards the forebay from the dam

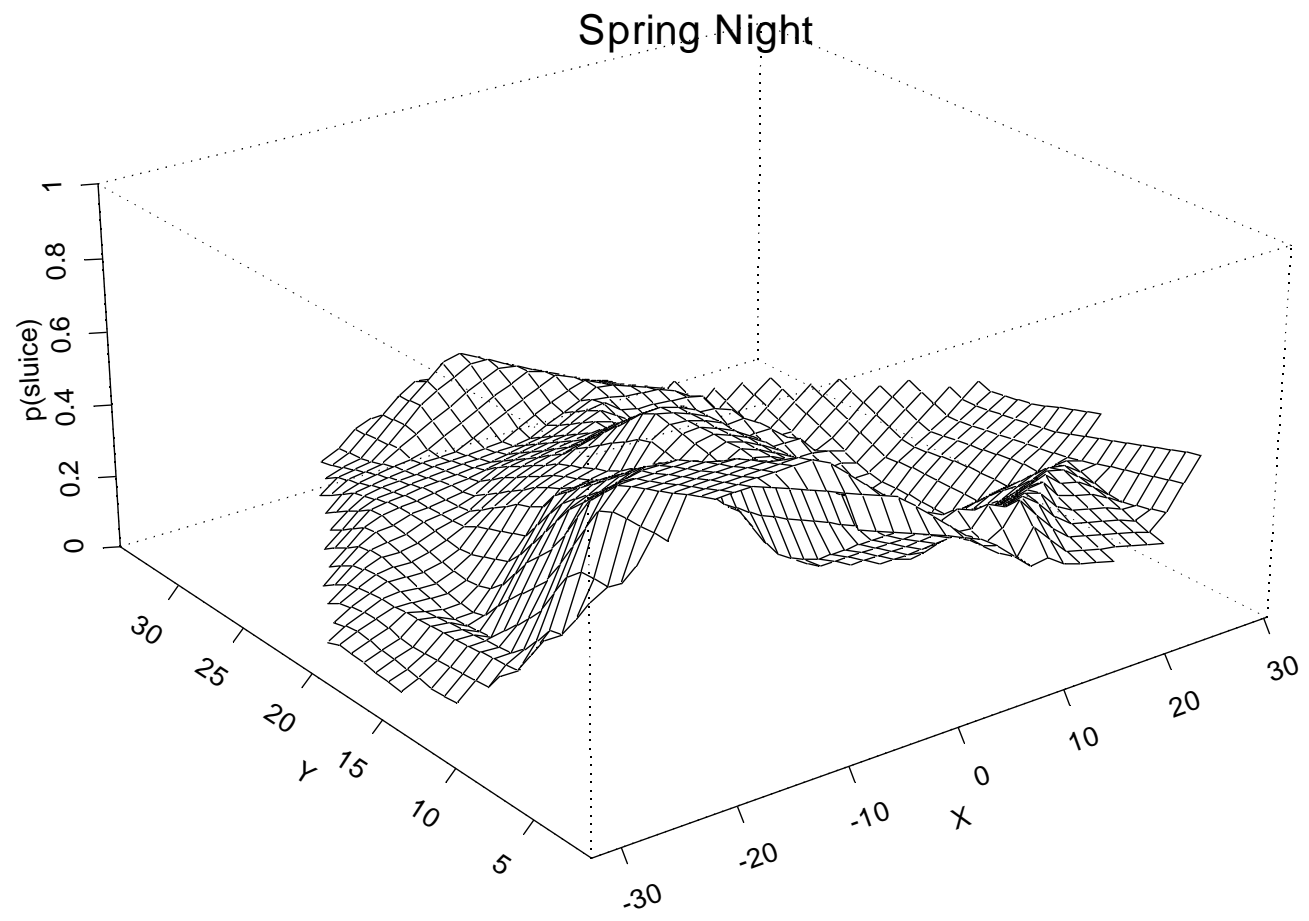

Figure B.4. Graphical plots of the proportions of PAMs projected into the sluiceway as a function of fish forebay location for the spring-night scenario at The Dalles Dam in 2004. Subplot (a) raw counts by location, (b) observed proportions by location, (c) 2D contour plot, (d) 3D contour plot looking toward the dam from the forebay, and (e) 3D contour plot looking toward the forebay from the dam. 
a. Raw counts by location

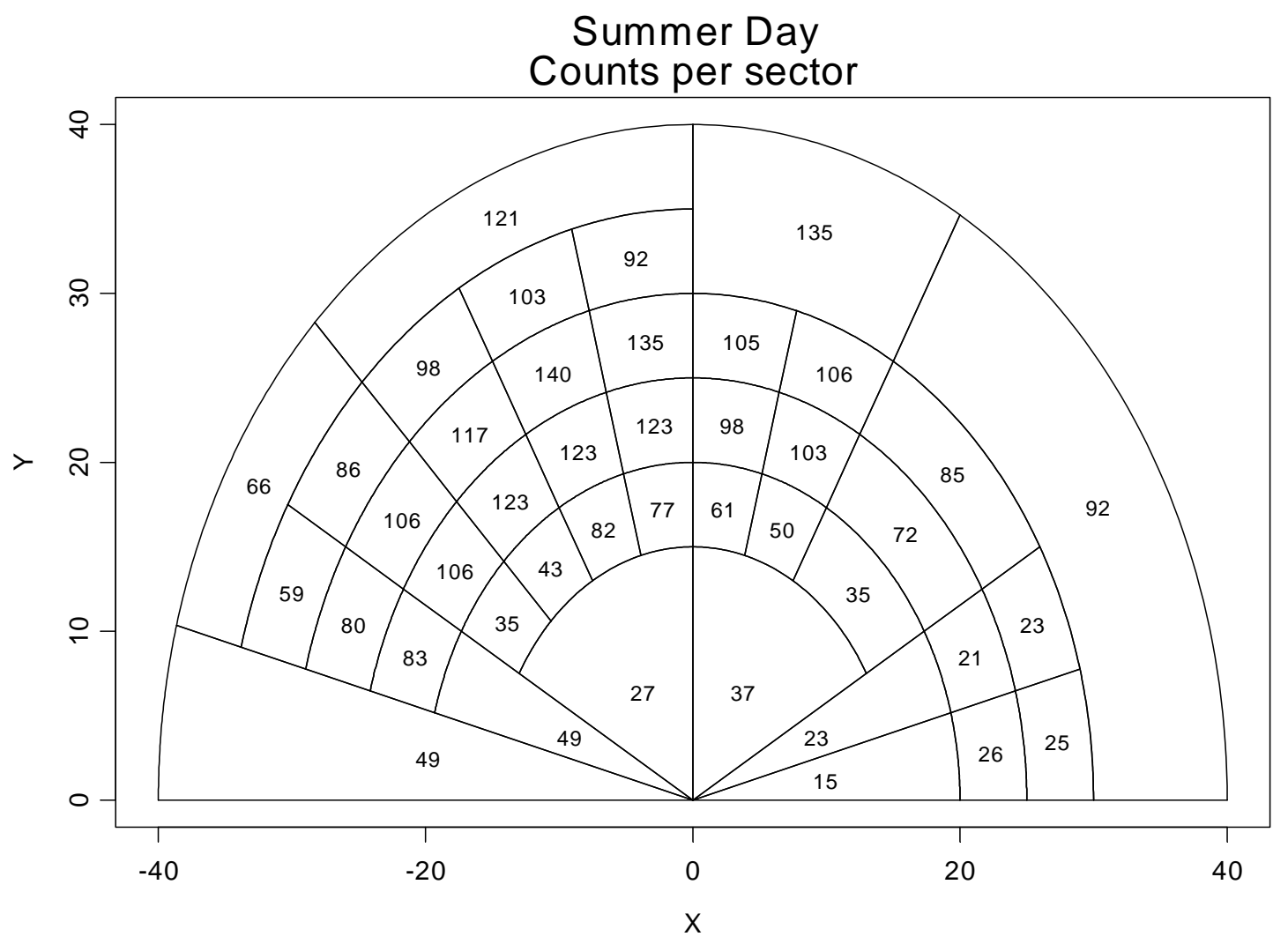

b. Observed proportions by location

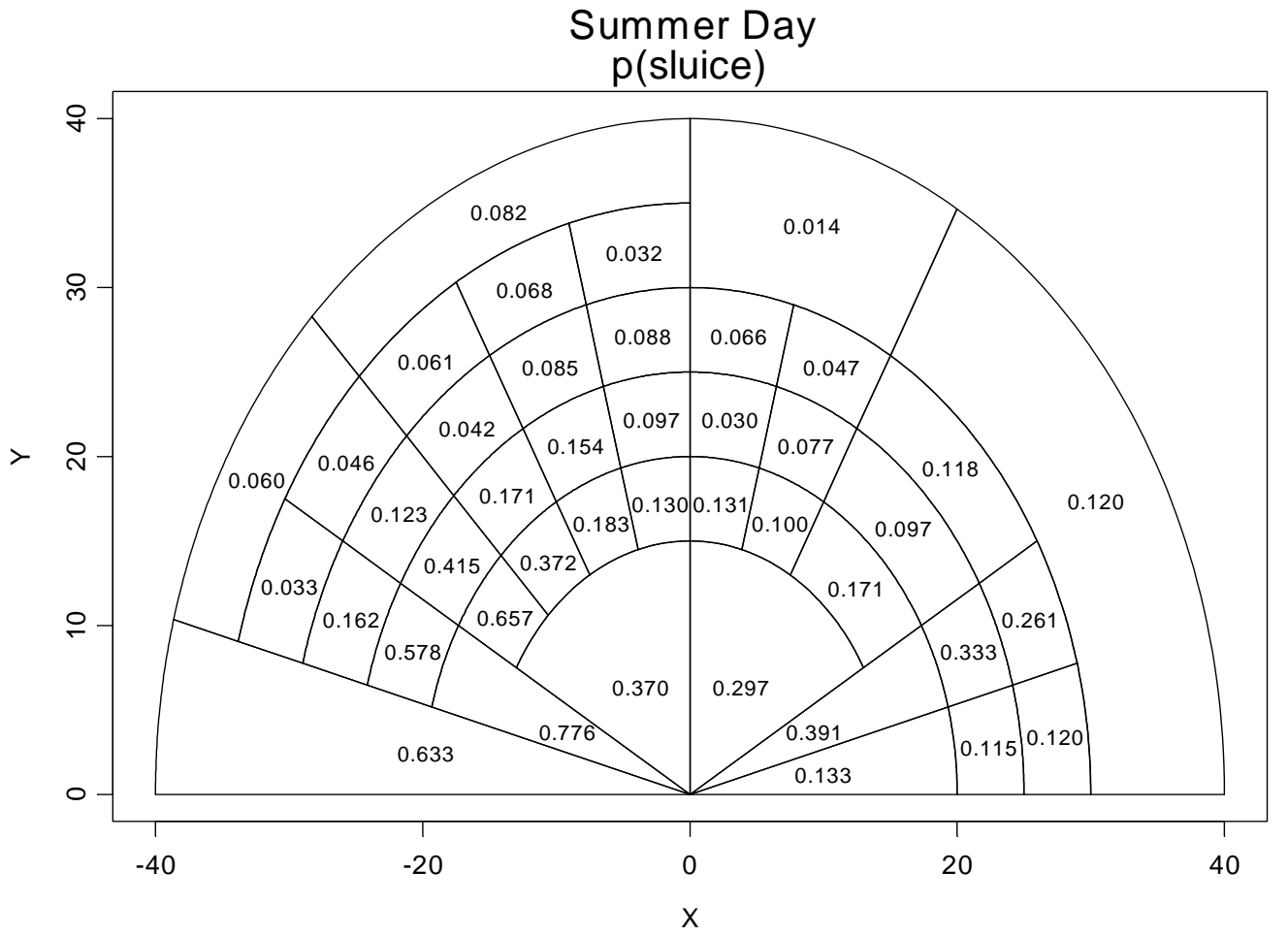


c. $2 \mathrm{D}$ contour plot

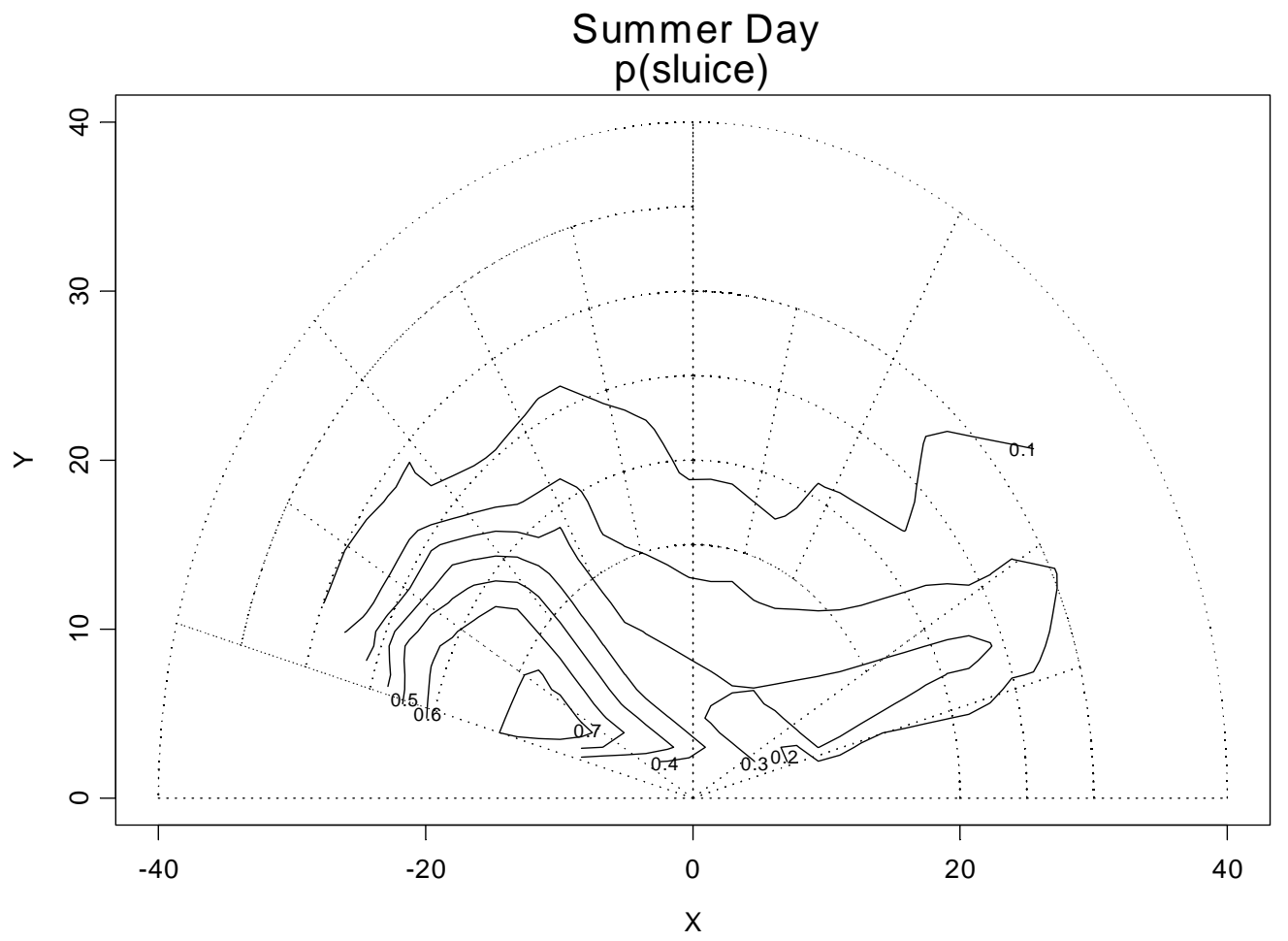

d. $3 \mathrm{D}$ contour plot looking toward the dam from the forebay Summer Day

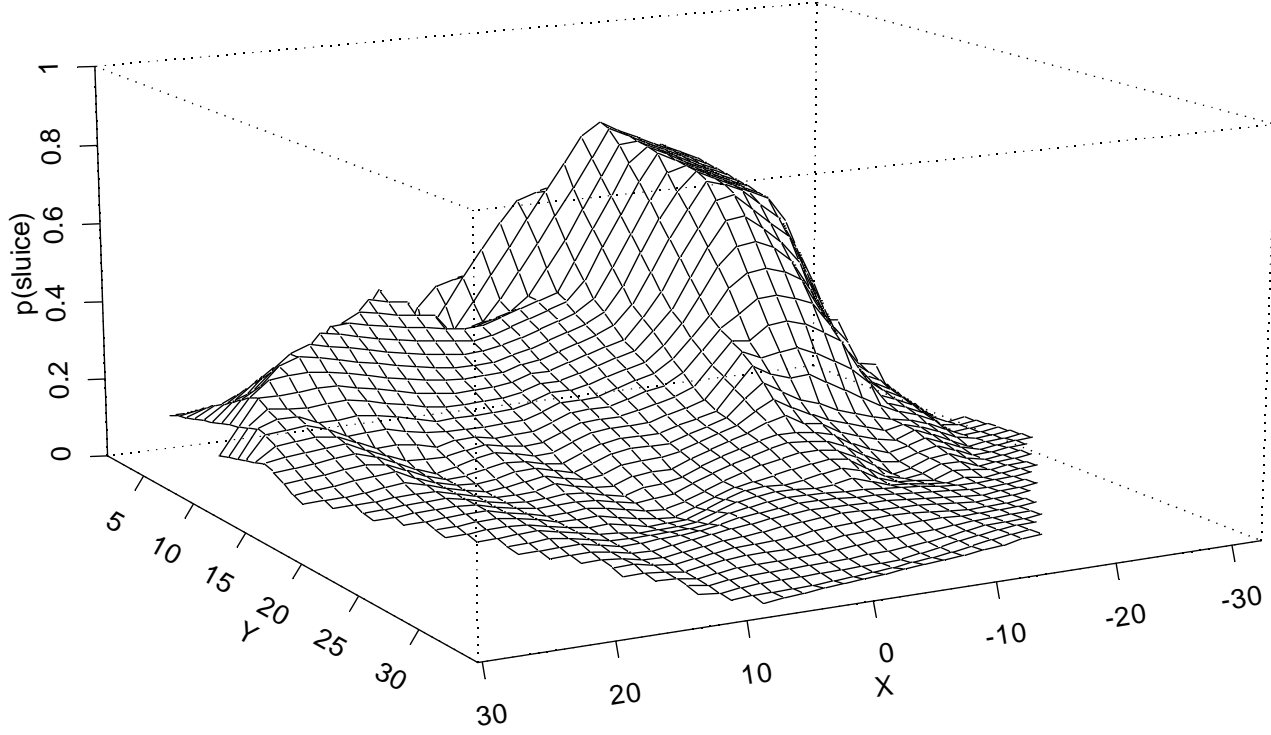

e. 3D contour plot looking towards the forebay from the dam 


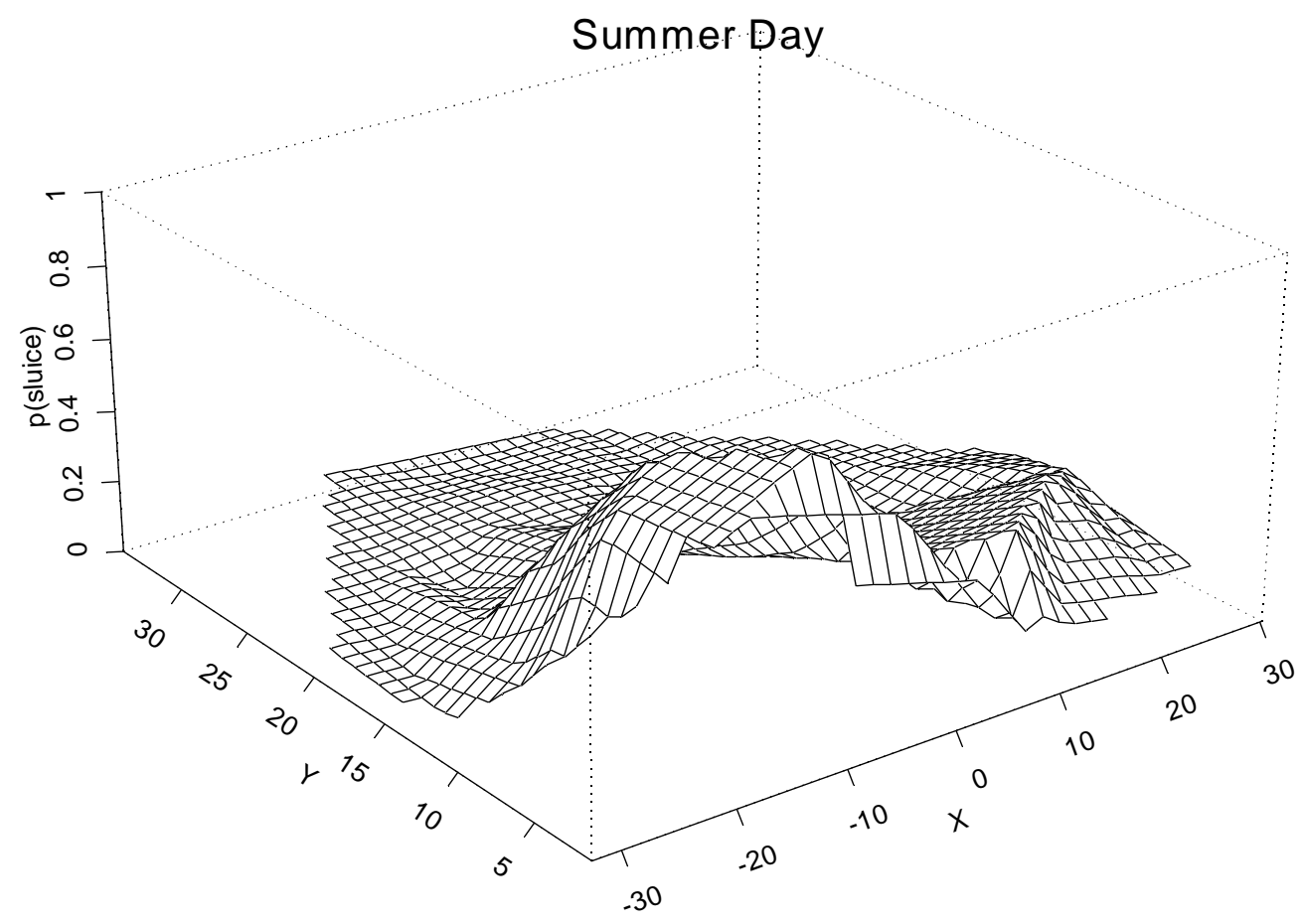

Figure B.5. Graphical plots of the proportions of PAMs projected into the sluiceway as a function of fish forebay location for the summer-day scenario at The Dalles Dam in 2004. Subplot (a) raw counts by location, (b) observed proportions by location, (c) 2D contour plot, (d) 3D contour plot looking toward the dam from the forebay, and (e) 3D contour plot looking toward the forebay from the dam. 
a. Raw counts by location

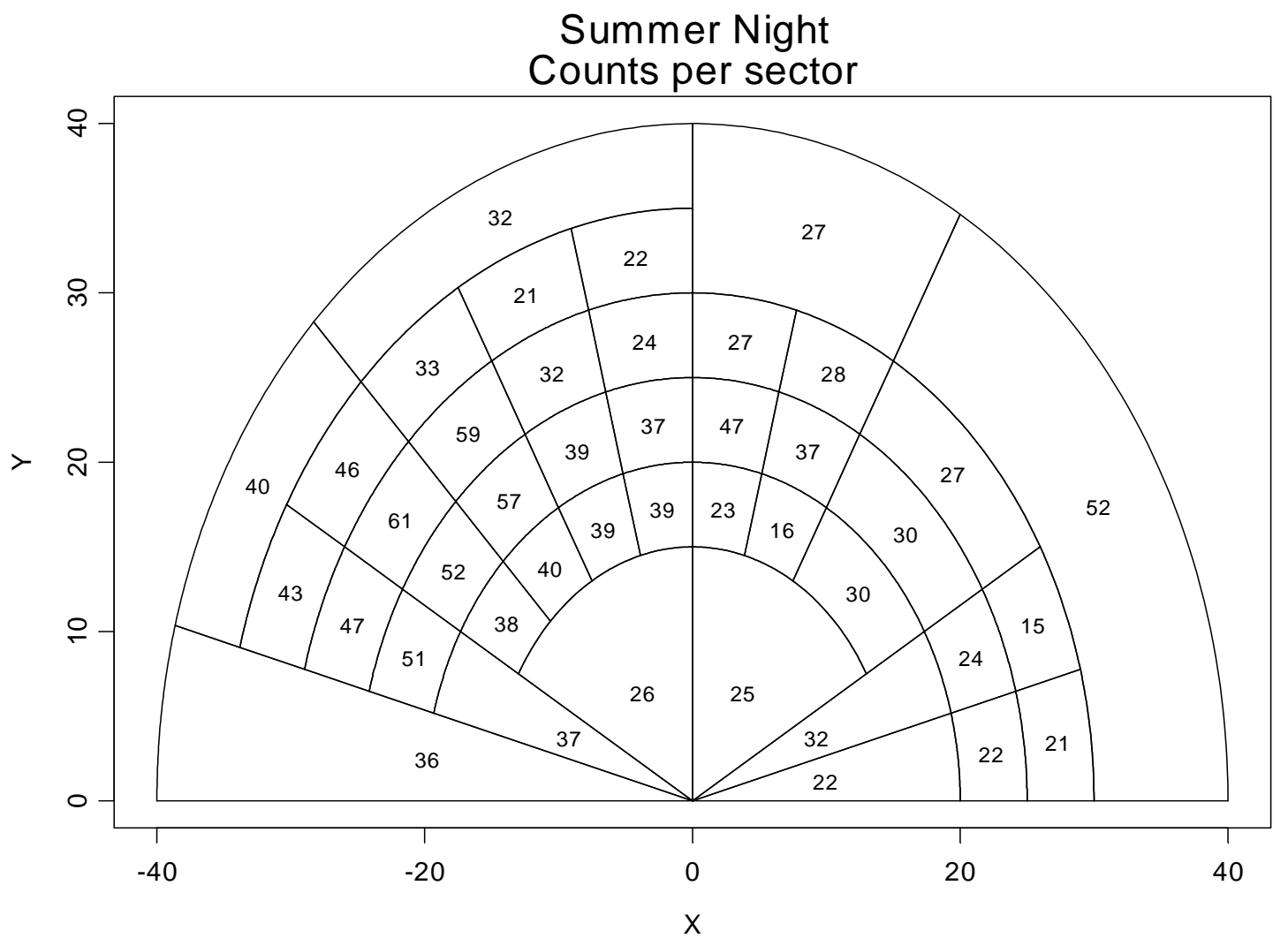

b. Observed proportions by location

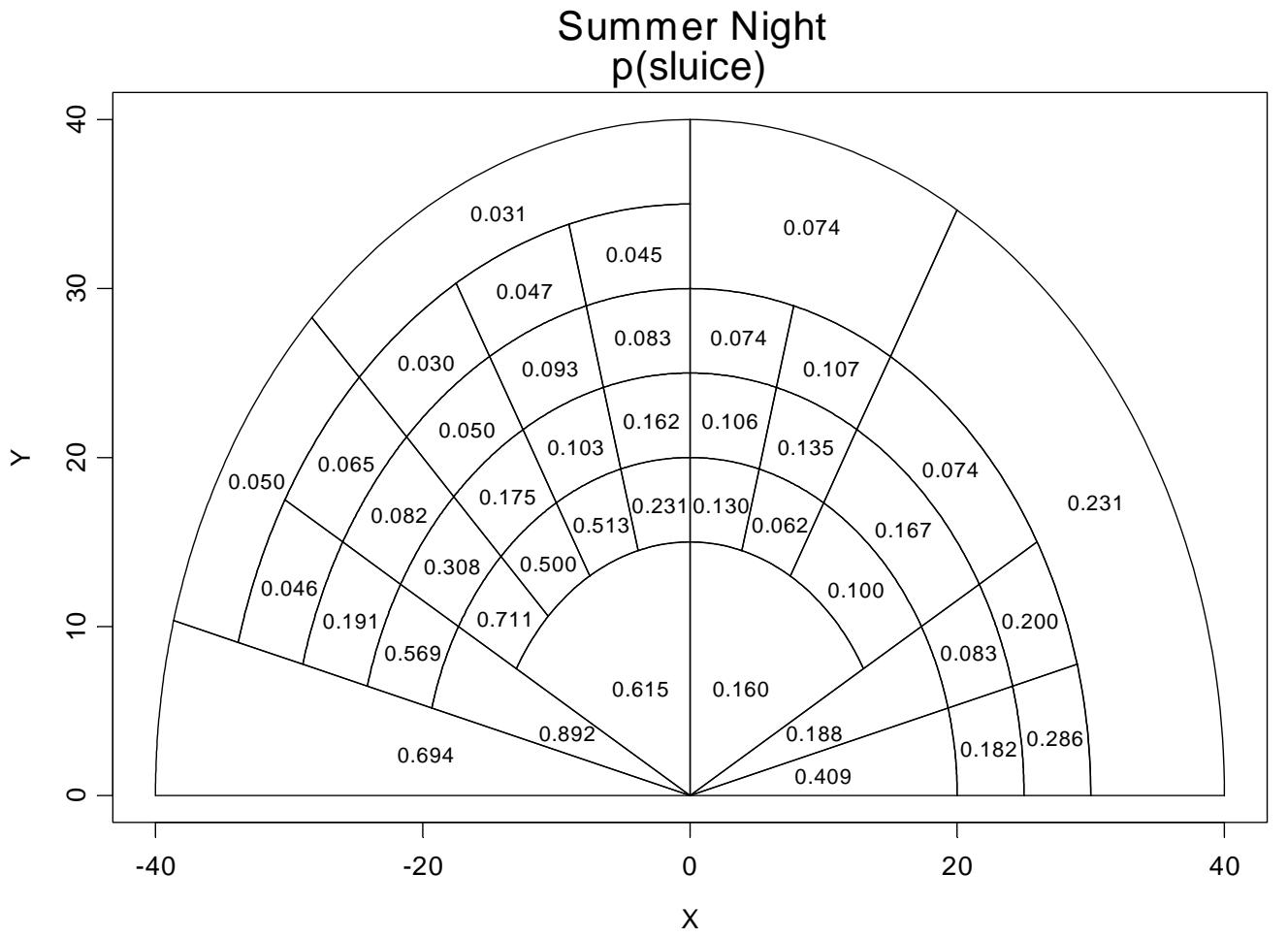


c. $2 \mathrm{D}$ contour plot

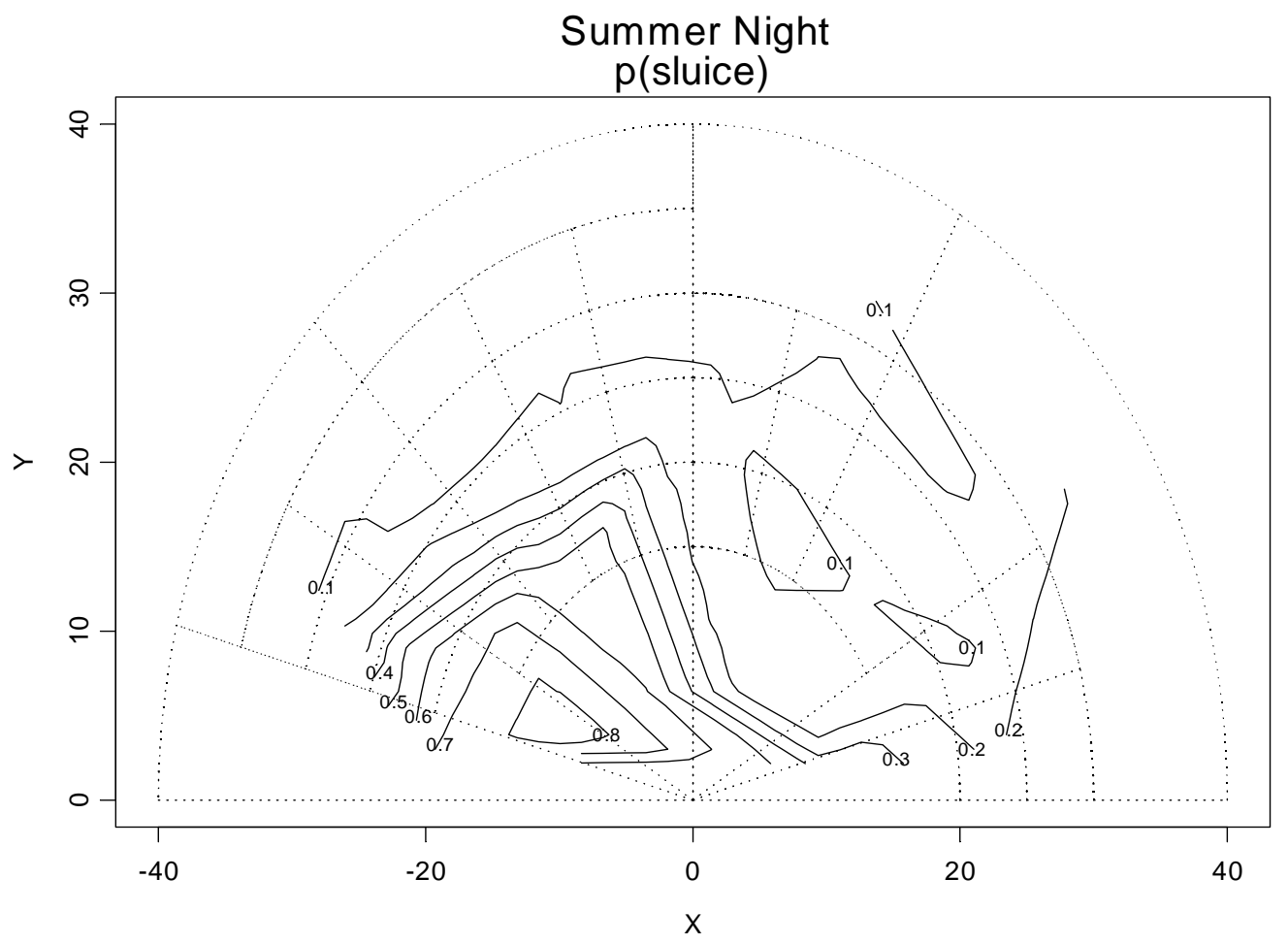

d. 3D contour plot looking toward the dam from the forebay

\section{Summer Night}

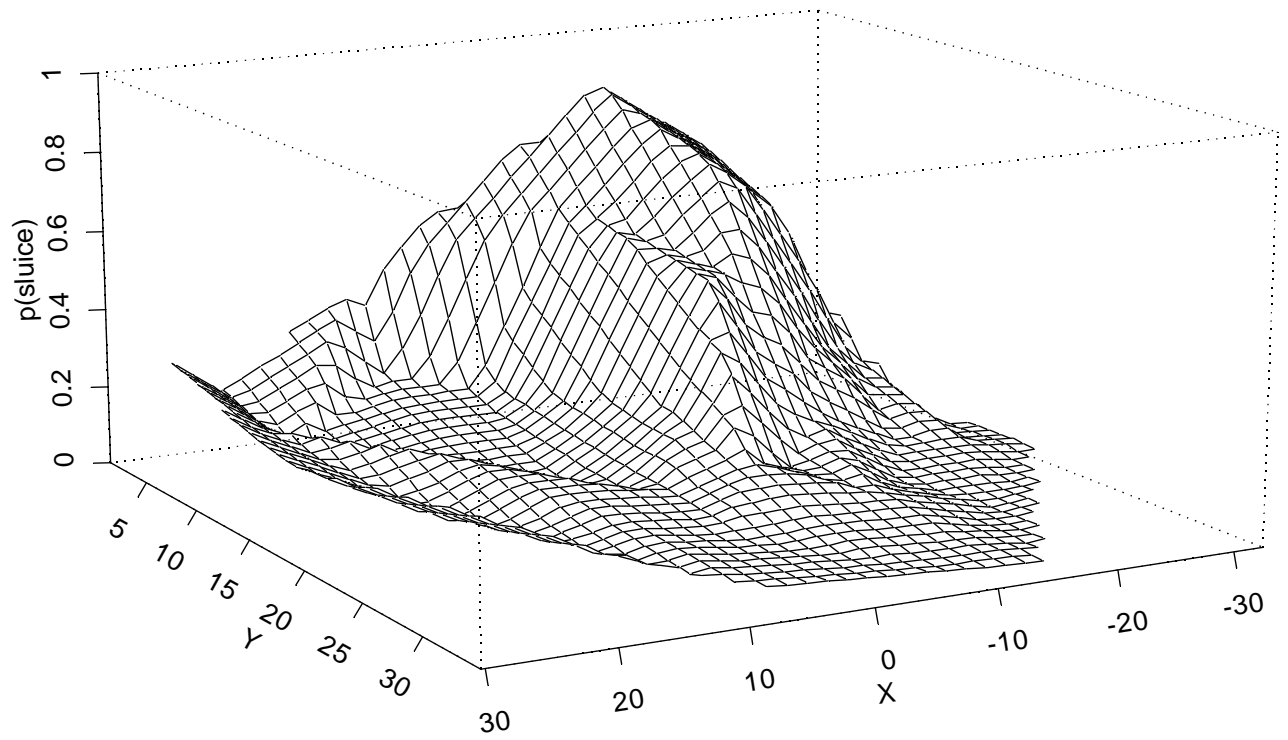


e. 3D contour plot looking towards the forebay from the dam

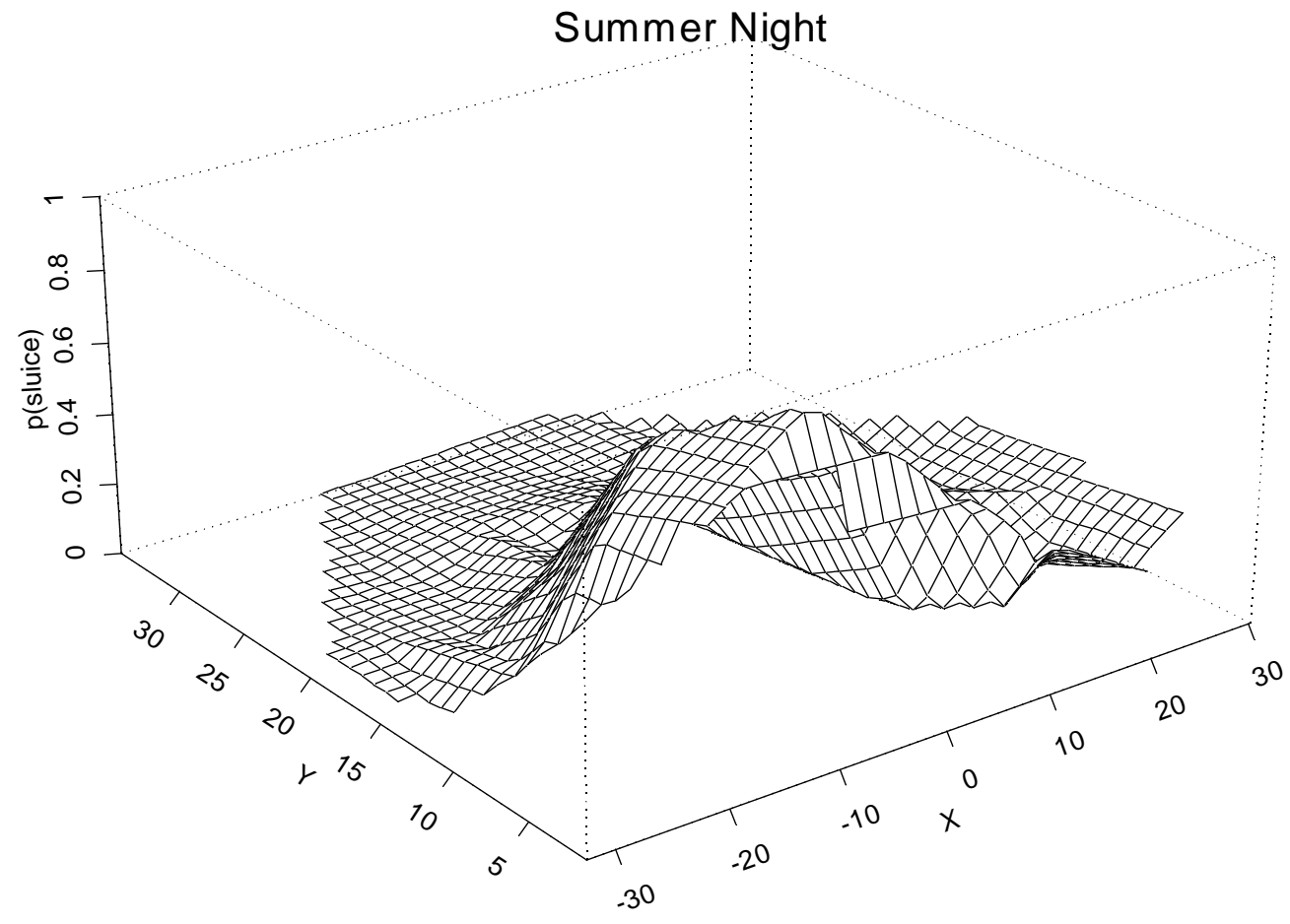

Figure B.6. Graphical plots of the proportions of PAMs projected into the sluiceway as a function of fish forebay location for the summer-night scenario at The Dalles Dam in 2004. Subplot (a) raw counts by location, (b) observed proportions by location, (c) 2D contour plot, (d) 3D contour plot looking toward the dam from the forebay, and (e) 3D contour plot looking toward the forebay from the dam. 